\title{
ALVARO NAKANO
}

Simulação de desempenho energético de tecnologias fotovoltaicas em fachada de edifício no município de São Paulo

São Paulo

(2017) 


\section{ALVARO NAKANO}

Simulação de desempenho energético de tecnologias fotovoltaicas em fachada de edifício no município de São Paulo

Dissertação apresentada à Escola Politécnica da Universidade de São Paulo para obtenção do título de Mestre em Ciências

Orientador:

Prof. Dr. Racine Tadeu Araújo Prado

São Paulo

(2017) 


\section{ALVARO NAKANO}

Simulação de desempenho energético de tecnologias fotovoltaicas em fachada de edifício no município de São Paulo

Dissertação apresentada à Escola Politécnica da Universidade de São Paulo para obtenção do título de Mestre em Ciências

Área de Concentração: Inovação na Construção Civil

Orientador:

Prof. Dr. Racine Tadeu Araújo Prado.

São Paulo 
Este exemplar foi revisado e corrigido em relação à versão original, sob responsabilidade única do autor e com a anuência de seu orientador.

São Paulo, de de

Assinatura do autor:

Assinatura do orientador:

NAKANO, ALVARO

Simulação de desempenho energético de tecnologias fotovoltaicas em fachada de edifício no município de São Paulo / A. NAKANO -- versão corr. -São Paulo, 2017.

$143 \mathrm{p}$.

Dissertação (Mestrado) - Escola Politécnica da Universidade de São Paulo. Departamento de Engenharia de Construção Civil.

1.ENERGIA SOLAR 2.CÉLULAS SOLARES 3.SISTEMAS

FOTOVOLTAICOS 4.FACHADAS 5.EDIFÍCIOS I.Universidade de São Paulo. Escola Politécnica. Departamento de Engenharia de Construção Civil Il.t. 
NAKANO, A. Simulação de desempenho energético de tecnologias fotovoltaicas em fachada de edifício no município de São Paulo. São Paulo. 2017. 143 p. (Mestrado) Escola Politécnica, Universidade de São Paulo, São Paulo, 2017.

\section{ERRATA}

\begin{tabular}{|l|l|l|l|}
\hline FOLHA & LINHA & ONDE SE LE & LEIA-SE \\
PÁGINA & & & \\
\hline & & & \\
\hline & & & \\
\hline
\end{tabular}


Dedico este trabalho a

minha esposa, Ângela, com amor, admiração e gratidão por sua compreensão, carinho, presença e incansável apoio, sempre.

Aos meus filhos, Gustavo e Nathália, as minhas pedras mais preciosas que lapidei com amor, atenção e alegria.

À minha mãe, com amor $\mathrm{e}$ carinho, que mesmo nos momentos desfavoráveis nunca deixou de exalar alegria em seu coração.

Ao meu pai (in memorian), com amor e carinho, que proporcionou o crescimento de minha responsabilidade.

Ao meu sempre amigo e incentivador Hikoki Kawashima. 


\section{AGRADECIMENTOS}

Aos Professores do curso de Mestrado Profissional em Inovação na Construção Civil, que nos anos de convivência, muito me ensinou, contribuindo para meu crescimento científico e intelectual.

Ao Professor Dr. Racine Tadeu Araújo Prado, pela atenção e apoio durante o processo de definição e orientação, pela condução sempre incentivadora e pelo alto nível de aprendizado que sustentou o desenvolvimento deste trabalho.

Aos Professores Dr. José Roberto Simões Moreira e Dr. Daniel Setrak Sowmy, pela importante contribuição em minha carreira de pesquisa desde o primeiro curso de energias renováveis pelo PECE USP.

À Escola Politécnica da Universidade de São Paulo, pela oportunidade de realização do curso de Mestrado.

Aos colegas do curso, com quem firmei um alto grau de amizade, de companheirismo e de união. 
Perseguimos o saber, com a missão de abastecer de conhecimento àqueles que 0 buscam.

(Alvaro Nakano) 


\section{RESUMO}

As tecnologias usualmente aplicadas no mercado fotovoltaico mundial são, em sua maioria, voltadas aos painéis rígidos de células de silício cristalino, em função da redução de seus preços proporcionada pela economia de escala. No entanto, a crescente demanda no País de novos domicílios, principalmente de apartamentos, tem exigido soluções mais apropriadas: com menor ocupação de área horizontal e instaladas na fachada dos edifícios. Nesse sentido vão surgindo tecnologias fotovoltaicas como as de filmes finos como soluções mais apropriadas do que as emergentes de terceira geração, pelo fato dessas últimas ainda se encontrarem em fase de maturação técnica com poucas opções de fornecimento no mercado em nível comercial. Portanto, a abordagem desta dissertação se limitou às tecnologias de filmes finos e de vidros fotovoltaicos semitransparentes, além daquela mais usual que é a de silício cristalino. Contudo, o dinamismo do mercado mundial vem estimulando uma evolução no fator de desempenho dessas tecnologias, o que justificou a necessidade de uma revisão bibliográfica. Além disso, a maioria dos projetos fotovoltaicos vem adotando como base os painéis rígidos com células de silício cristalino, sem, no entanto, avaliarem alternativas com a aplicação de outras tecnologias. O que se nota é a falta de conhecimento mais profundo dos projetistas sobre as tecnologias de filmes finos e das melhores opções para sua aplicação em um edifício, no que tange ao seu desempenho e seu comportamento dentro do espectro de frequência. Assim, esta dissertação teve por objetivo contribuir com uma análise de desempenho energético com base em simulações para tomada de decisão técnica sobre as tecnologias mais adequadas de célula fotovoltaica para sistemas a serem instalados em fachadas de edifícios, auxiliadas por uma ferramenta computacional existente no mercado, o PVSYST. A tomada de decisão foi vista pela perspectiva de desempenho na geração de energia elétrica, pela análise comparativa dos resultados de simulações aplicadas na fachada de um edifício hipotético em São Paulo. Os resultados mostraram que as tecnologias baseadas no silício cristalino são as mais adequadas nos casos em que o pico de demanda de energia no ano seja no verão, como nos edifícios comerciais. Já os sistemas compostos pelos filmes finos do grupo do seleneto de índio e cobre são os mais indicados para os edifícios residenciais, em que o período de maior demanda é no inverno.

Palavras-Chave: Tecnologias fotovoltaicas. Silício cristalino. Filmes finos. Vidros fotovoltaicos. Simulações. Fachadas de edifícios. Desempenho energético. 


\begin{abstract}
Technologies commonly applied in the global photovoltaic market are mostly with the rigid panels of crystalline silicon cells, due to the reduction of their prices provided by economies of scale. However, growing demand in the country of new housing units, mainly apartments, has required more appropriated solutions: with lower occupancy of horizontal area and installed on the building's facade. In this direction photovoltaic technologies are emerging such as thin films as better solutions than the emerging technologies of third generation, because still they are in technical maturation phase with few options of suppliers in the commercial market. Therefore, the approach of this dissertation was limited to technologies of thin films and semitransparent photovoltaic glazing, in addition to the more usual one that is crystalline silicon. However, the dynamism of the global market has stimulated an evolution in the performance factor of these technologies, which justified the necessity of literature review. Furthermore, most PV projects have been based on the rigid panels with crystalline silicon cells, not considering the alternatives using other technologies. What is noticed is the lack of deeper understanding of the designers about the thin film technologies and the best options for their application in a building, in terms of their performance and their behavior within the frequency spectrum. Thus, this work aimed to contribute to an energy performance analysis based on simulations for technical decision on the most appropriate photovoltaic cell technologies for systems to be installed on the facades of buildings, aided by an existing software tool on the market, PVSYST. Decision making was seen from the perspective of performance in electricity generation, by comparative analysis of simulations results applied on the facade of a hypothetical building in São Paulo. The results showed that the technologies based on crystalline silicon are the most appropriate in cases where energy demand peak in the year is in the summer, as in commercial buildings. On the other hand, the systems composed of the thin films based on indium and copper selenium group are the most suitable for residential buildings, where the period of greatest demand is in the winter.
\end{abstract}

Keywords: Photovoltaic Technologies. Crystalline silicon. Thin films. Photovoltaic glazing. Simulations. Facades of buildings. Energy performance. 


\section{LISTA DE FIGURAS}

Figura 1.1 - Evolução do nível dos reservatórios das usinas hidrelétricas do subsistema SE/CO.........20

Figura 1.2 - Matriz de capacidade instalada de geração de energia elétrica do Brasil ........................23

Figura 1.3 - Participação das tecnologias fotovoltaicas no mercado mundial ...................................24

Figura 2.1 - Perspectiva do mercado mundial fotovoltaico …......................................................27

Figura 4.1 - Diagrama de blocos de sistema fotovoltaico conectado à rede de baixa tensão.................38

Figura 4.2 - Curva I-V de uma célula solar fotovoltaica típica ….....................................................39

Figura 4.3 - Variação da curva I-V em função da radiação e da temperatura .....................................39

Figura 4.4- Variação da potência gerada em função das perdas internas da célula ..............................40

Figura 4.5 - Fator de forma: relação entre a máxima potência real PMP e a potência teórica ideal PT 41

Figura 4.6 - Diagrama esquemático de um inversor com monitoramento e controle ..........................45

Figura 4.7 - Interligação de células fotovoltaicas ..........................................................................

Figura 4.8 - Curva característica de corrente-tensão do módulo solar ................................................49

Figura 4.9 - Efeito causado na curva I-V do módulo em função do nível de radiação .........................49

Figura 4.10 - Efeito causado na curva I-V do módulo fotovoltaico pela variação da temperatura.........50

Figura 4.11 - Agrupamentos das tecnologias de células fotovoltaicas .............................................52

Figura 4.12 - Estrutura do painel rígido fotovoltaico de silício cristalino .........................................54

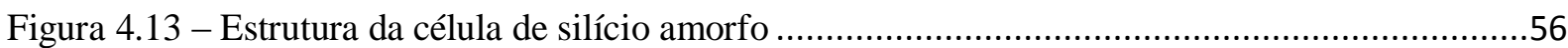

Figura 4.14 - Desenho esquemático de uma célula típica de CdTe.................................................58

Figura 4.15 - Participação das tecnologias fotovoltaicas nos BIPVs................................................63

Figura 5.1 - Modelo conceitual do método aplicado (visão macro) ..................................................70

Figura 5.2 - Top Ten mundial de fabricantes de módulos fotovoltaicos (ano 2015)............................75

Figura 5.3- Edifício hipotético com módulos fotovoltaicos na fachada ............................................81

Figura 5.4 - Carta solar para o município de São Paulo - base tempo solar.........................................83

Figura 5.5- Edifício hipotético inserido e posicionado no software PVSYST ....................................84

Figura 5.6- Posicionamento dos módulos fotovoltaicos no software PVSYST .................................88 
Figura 5.7 - Diagrama esquemático das variáveis de entrada do software PVSYST

Figura 5.8 - Diagrama esquemático das simulações sucessivas e variáveis adicionais .........................96

Figura 6.1 - Diagrama funcional básico do sistema fotovoltaico ..................................................98

Figura 6.2 - Diagrama de perdas no sistema fotovoltaico (anual) ................................................101

Figura 6.3- Perdas devido à temperatura e à variação de irradiância ...............................................104

Figura 6.4 - Pareto da Densidade de Energia anual gerada por tecnologia ....................................108

Figura 6.5 - Comparativo da Densidade de Energia anual gerada por unidade de área de módulos...109

Figura 6.6- Sensibilidade espectral dos materiais e do olho humano......

Figura 6.7 - Parcela de variação da densidade de energia gerada por unidade de área de módulos fotovoltaicos no inverno em relação ao verão

Figura 6.8 - Densidade de energia gerada e degradação das tecnologias fotovoltaicas .117

Figura 6.9- Densidade de energia gerada e sua variação entre estações verão-inverno 118 


\section{LISTA DE TABELAS}

Tabela 4.1 - Resumo das revisões da RN 687/2015 e tributárias ....................................................31

Tabela 4.2 - Resumo das alterações propostas nas revisões das Normas da ABNT …..........................36

Tabela 4.3 - Classificação das aplicações de BIPVs.....................................................................62

Tabela 5.1 - Critérios de classificação dos módulos fotovoltaicos segundo PBE ................................73

Tabela 5.2 - Eficiência Energética - Sistema de Energia Fotovoltaica - Módulos (Resumo) ..............74

Tabela 5.3 - Eficiências de módulos terrestres confirmadas sob regime STC ...................................76

Tabela 5.4 - Matriz de seleção das tecnologias simuladas............................................................77

Tabela 5.5 - Variáveis meteorológicas do município de São Paulo ...................................................85

Tabela 5.6 - Valores usuais para o albedo - base banco de dados do PVSYST …...........................87

Tabela 5.7-Composição dos sistemas fotovoltaicos por tecnologia ................................................93

Tabela 6.1 - Resumo dos resultados - Energia anual gerada por tecnologia ....................................99

Tabela 6.2 - Eficiências por tecnologia e fabricante adotado .....................................................102

Tabela 6.3 - Resultados das simulações - Energias anuais geradas pelo sistema fotovoltaico............105

Tabela 6.4- Resultados das simulações - Densidade de energia anual gerada (Earray) e de potência por área ocupada pelo arranjo fotovoltaico …….......................................................................106

Tabela 6.5 - Participação (\%) da energia gerada em corrente contínua por estação em relação ao

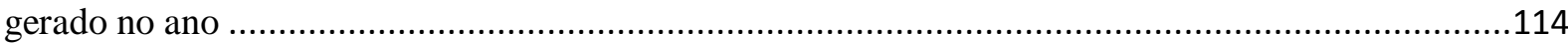

Tabela 6.6 - Índices de degradação de células fotovoltaicas .......................................................116 


\section{LISTA DE ABREVIATURA E SIGLAS}

A

ABNT

ACR

ANEEL

$\mathrm{a}-\mathrm{Si} / \mathrm{m}-\mathrm{Si}$

$\mathrm{a}-\mathrm{Si} / \mathrm{nc}-\mathrm{Si}$

$\mathrm{a}-\mathrm{Si}: \mathrm{H}$

B2H6

$B A P V$

BDMEP

BIG

$B I P V$

$B O S$

CA

CBIC

$\mathrm{CC}$

$\mathrm{CdTe}$

CE

$\mathrm{CGH}$

CIGS(S)

COFINS

CONFAZ

CPV

CRESESB

$\mathrm{c}-\mathrm{Si}$

DOU

DSSC

EAR

EMUC

EPE
Amperes

Associação Brasileira de Normas Técnicas

Ambiente de Contratação Regulada

Agencia Nacional de Energia Elétrica

Junção de silício amorfo/silício policristalino

Junção de silício amorfo/silício nano cristalino

Célula de silício amorfo hidrogenado

Diborano

Building Attached (ou Adapted) Photovoltaic (fotovoltaico anexado ou adaptado à edificação)

Banco de Dados Meteorológicos para Ensino e Pesquisa

BOLETIM DE INFORMAÇÕES DE GERAÇÃO da ANEEL

Building Integrated Photovoltaic (fotovoltaico integrado à edificação)

Balance of System

Corrente alternada

Câmara Brasileira da Indústria da Construção Civil

Corrente contínua

Célula de telureto de cadmio

Comissão de Estudos

Central geradora hidrelétrica

Célula de (dis)seleneto de cobre, índio e gálio

Contribuição para Financiamento da Seguridade Social

Conselho Nacional de Política Fazendária

Concentradores fotovoltaicos

Centro de Referência para Energia Solar e Eólica

Silício monocristalino

Diário Oficial da União

Dye Sensitized Solar Cell (célula solar sensibilizada por corante)

Índice de Energia Armazenada por Região das UHEs

Empreendimento com múltiplas unidades consumidoras

Empresa de Pesquisa Energética 
$\mathrm{eV}$

EVA

FDI

FF

FIAM ou Fator IAM

FT

$\mathrm{FV}$

GaAs

GaAsAl

GD

GW

GWp

HOMER

IAM

IBGE

ICMS

IEA

IEC

INMET

INMETRO

INSEL

IPI

I-V

K

$\mathrm{kW}$

KWh

LER

LID ou $S W$

$\mu \mathrm{m}$

$\mathrm{MJ} / \mathrm{m}^{2} \mathrm{dia}$

MME

$\mathrm{m} / \mathrm{s}$
Elétron-Volt

Acetato de vinil etileno

Fator de dimensionamento do inversor

Fator de forma ou fill fator

Fator modificador do ângulo de incidência

Fator de transposição

Fotovoltaico

Arseneto de gálio

Arseneto de galio e alumínio

Geração Distribuída de energia elétrica

Gigawatts

Gigawatts-pico

Hybrid Optimization Model for Electric Renewable

Fator modificador do ângulo de incidência

Instituto Brasileiro de Geografia e Estatística

Imposto sobre circulação de mercadorias e serviços

International Energy Agency

International Electrotechnical Commission

Instituto Nacional de Meteorologia

Instituto Nacional de Metrologia, Qualidade e Tecnologia

Integrated Simulation Enviroment Language

Imposto sobre produto industrializado

Corrente-tensão

Kelvin

Quilo-Watt

Quilo-Watt-hora

Leilões de Energia de Reserva

Efeito de degradação induzida pela luz ou efeito Staebler-Wronski

Micrômetro

Mega Joules por metro quadrado dia

Ministério de Minas e Energia

Metros por segundo 
m-Si

MW

MWp

nm

NREL

O.N.S

$O P V$

P,D\&I

PBE

PH3

PIS

PVF

RTE

SEAC

SFCR

$\mathrm{SiH} 4$

SIN

$\mathrm{SnO} 2$

SPMP

STC

SUPSI

TCO

TF

TNOC

ucSi-aSiH

UHE

UTE

V

Vidro FVST

W

$\mathrm{Wh} / \mathrm{m}^{2}$

$\mathrm{W} / \mathrm{m}^{2} \mathrm{~K}$
Silício policristalino ou multicristalino

Mega-Watt

Megawatts-pico

Nanômetro

National Renewable Laboratory

Operador Nacional do Sistema Elétrico

Organic Photovoltaic Cell (célula fotovoltaica orgânica)

Pesquisa, Desenvolvimento e Inovação

Programa Brasileiro de Etiquetagem

Hidreto de fósforo

Programas de Integração Social

Fluoreto de polivinila

Revisão Tarifária Extraordinária.

Solar Energy Application Centre

Sistemas fotovoltaicos conectados a rede

Silano

Sistema Interligado Nacional de energia elétrica

Dióxido de estanho

Seguidor do Ponto de Máxima Potência

Standard Test Condition

University of Applied Sciences and Arts of Southern Switzerland

Óxido condutor transparente

Thin Films Cell (célula de filme fino)

Temperatura nominal de operação da célula

Junção de silício microcristalino-silício amorfo hidrogenado

Usina Hidrelétrica com reservatório

Usina Termelétrica

Volts

Vidro fotovoltaico semitransparente

Watts

Watt-hora por metro quadrado

Watt por metro quadrado Kelvin 


\section{LISTA DE SÍMBOLOS}

bo

$\mathrm{E}_{\text {dia gerada } \mathrm{FV}}$

$E_{\text {dia gerada sist }}$

$E_{\text {Grid }}$

$\mathrm{E}_{\text {mes gerada sist }}$

Earray

EarrMPP

EarrNom

EffarrR

EffsysR

efic

Efic $_{\text {STC }}$

Eoutinv

Ghor

Ginc

GlobEff

GlobHor

GlobInc

$\mathrm{H}$

$\mathrm{H}_{\text {refS }}$

$\mathrm{H}_{\text {refT }}$

$\mathrm{Ht}$

HT

i

$\mathrm{Ib}$

Icc ou Isc

Id

Imp

$\mathrm{N}$

$\mathrm{n}_{\text {mes }}$

$\mathrm{P}_{\text {carga }}$
Índice de refração da superfície (FIAM)

Energia entregue pelo gerador fotovoltaico

Energia diária média mensal gerada pelo sistema fotovoltaico

Corrente alternada injetada na rede (PVSYST)

Energia média mensal gerada pelo sistema fotovoltaico

Energia em corrente contínua produzida pelo gerador fotovoltaico

Energia fornecida ao inversor PMP (PVSYST)

Energia nominal do arranjo fotovoltaico a condições STC (PVSYST)

Eficiência do gerador fotovoltaico (PVSYST)

Eficiência do sistema (PVSYST)

Eficiência do módulo fotovoltaico

Eficiência do módulo sob condições de teste padrão (STC)

Energia disponível na saída do inversor (PVSYST)

Irradiação global no plano horizontal

Irradiância solar local no plano horizontal

Irradiação global efetiva sobre o módulo (PVSYST)

Irradiação global no plano horizontal (PVSYST)

Irradiação global sobre o plano do coletor (PVSYST),

Radiação integrada diária

Irradiação de referência nas condições STC

Irradiação de referência nas condições de teste para TNOC

Irradiação média mensal sobre a superfície inclinada

Radiação integrada diária média mensal sobre a superfície inclinada

Ângulo de incidência sobre o plano (FIAM)

Irradiância direta

Corrente de curto-circuito

Irradiância difusa

Corrente de potência máxima

Duração diária média mensal de insolação

Quantidade de dias no mês

Potência máxima demandada pela carga 
Pirrad

$\mathrm{Pm}_{\text {entregue ao inv }}$

Pm gerada FV

Pm

Pmp

$\mathrm{Pn}_{\text {inv }}$

PT

Ptemperat

$\mathrm{Qt}_{\text {modulos }}$

Qts min

Ta

Tamb

$\mathrm{Ta}_{\text {refT }}$

Tc

Tcel

$\mathrm{Tc}_{\text {refS }}$

$\mathrm{U}$

Uc

Uv

V

$\mathrm{Vm}$

$\mathrm{V}_{\text {módulo } 70^{\circ} \mathrm{C}}$

Vmp

Voc

$\mathrm{V}_{\text {PMP min }}$

Wp

$\alpha$

$\beta$

$\gamma$

$\gamma$
Perda em função da variação de irradiância

Potência máxima entregue ao inversor

Potência máxima gerada pelo arranjo fotovoltaico

Potência máxima gerada pelo coletor fotovoltaico

Potência máxima do coletor fotovoltaico, nas condições STC

Potência nominal do inversor ou sistema conversor

Potência teórica em condições ideais

Perda em função da temperatura do arranjo fotovoltaico

Quantidade de módulos fotovoltaicos

Quantidade mínima de módulos ligados em série do string

Temperatura ambiente média mensal

Temperatura ambiente

Temperatura ambiente de referência nas condições de teste para TNOC

Temperatura média mensal da célula

Temperatuta da célula

Temperatura de referência da célula nas condições STC

Fator de perda térmica (ou antigo valor-K)

Constante do fator de perda térmica

Fator de perda térmica proporcional à velocidade do vento

Velocidade do vento

Tensão de máxima potência nas condições STC

Tensão do módulo à temperatura de $70^{\circ} \mathrm{C}$

Tensão de potência máxima

Tensão de circuito aberto

Tensão mínima de PMP do inversor

Watts-pico

Coeficiente de absorção da radiação solar

Ângulo de inclinação da superfície

Ângulo de azimute da superfície

Coeficiente de temperatura na potência Pm 


\section{SUMÁRIO}

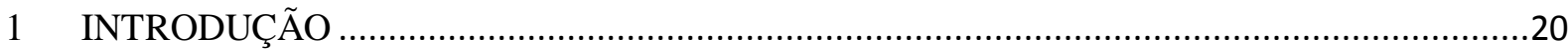

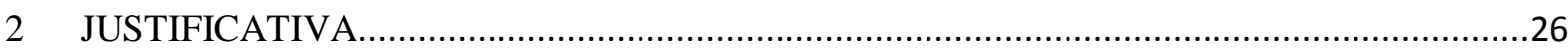

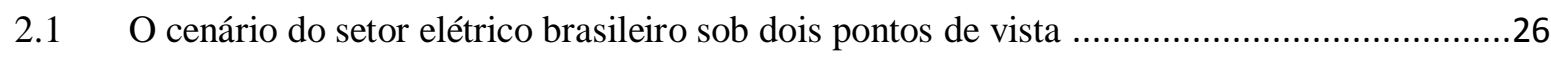

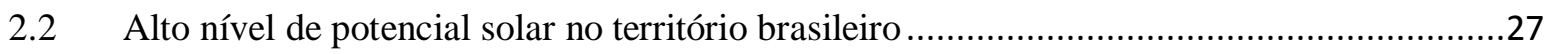

2.3 A inovação na construção de edificações sob a ótica do consumidor ....................................28

2.4 O panorama tecnológico, regulatório e tributário brasileiro …..........................................28

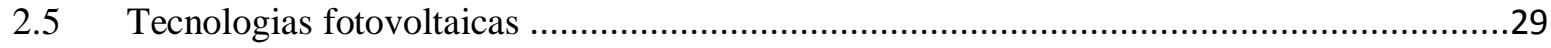

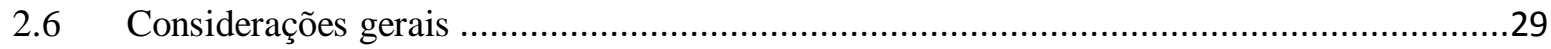

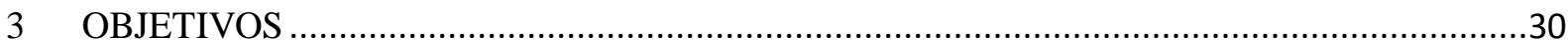

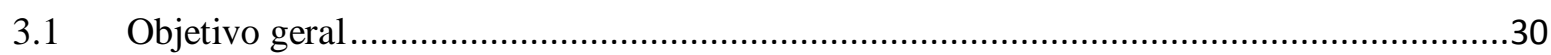

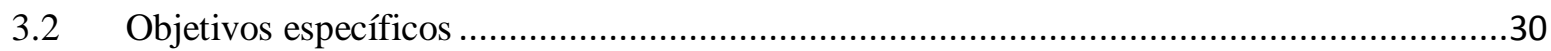

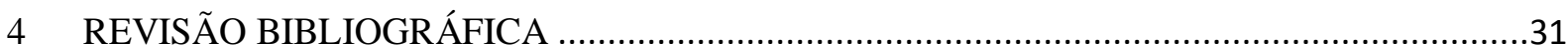

4.1 Revisão das normas e regulamentações técnicas e tributárias..............................................31

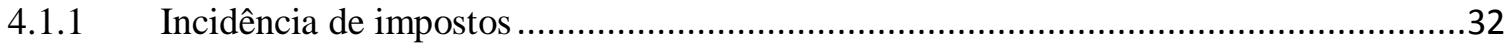

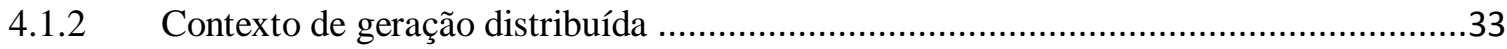

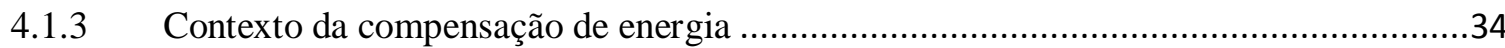

4.1.4 Custos do sistema de medição e de melhorias no sistema de distribuição ......................35

4.2 Normas técnicas da ABNT: aprimoramento em curso ..................................................35

4.2.1 NBR 16274: Sistemas fotovoltaicos conectados à rede — Requisitos mínimos para documentação, ensaios de comissionamento, inspeção e avaliação de desempenho ......................36

4.2.2 NBR 5410: Instalações elétricas de baixa tensão........................................................36

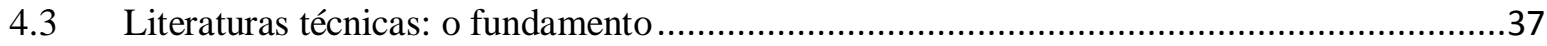

4.3.1 Conceito de Ponto de Máxima Potência - PMP ............................................................38

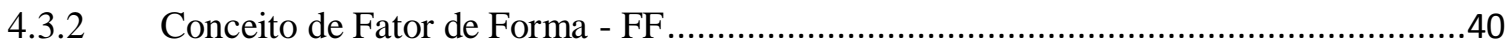

4.3.3 Determinação da potência fornecida pelo gerador fotovoltaico ....................................41

4.3.4 Determinação de energia produzida pelo gerador fotovoltaico …................................44

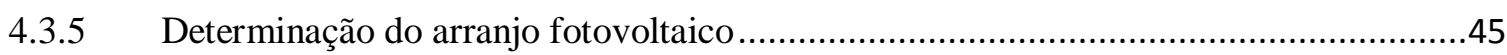

4.3.5.1 Dimensionamento do inversor - conversor CC-CA...............................................45

4.3.5.2 Dimensionamento do gerador fotovoltaico ....................................................... 48

4.4 Tecnologias fotovoltaicas: Estado da Arte................................................................. 52

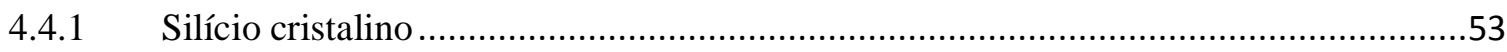

4.4.1.1 Painéis rígidos com células de silício cristalino......................................................53 


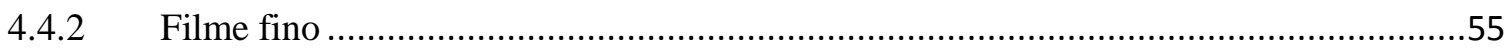

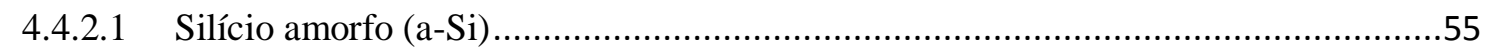

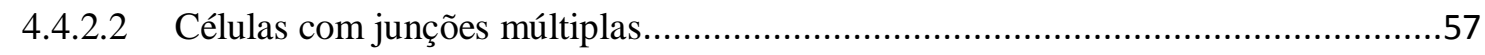

4.4.2.3 Telureto de cádmio (Cd-Te) ….........................................................................58

4.4.2.4 Disselenetos de cobre-índio (CIS) e de cobre-índio-gálio (CIGS) ............................59

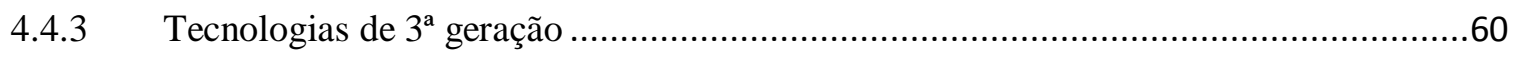

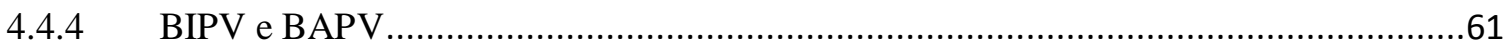

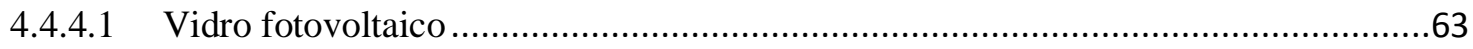

4.5 Ferramenta computacional: Software de simulação solar..................................................64

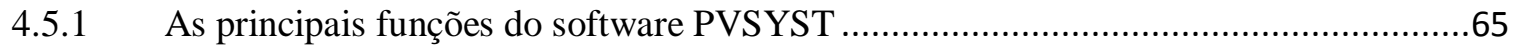

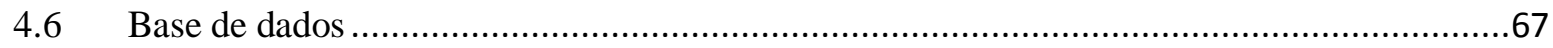

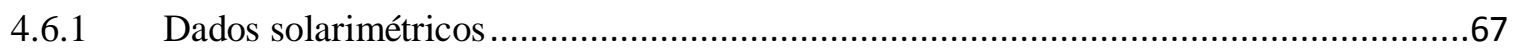

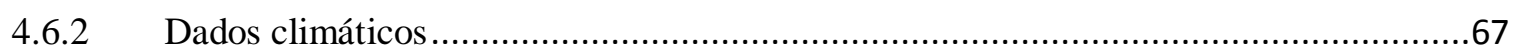

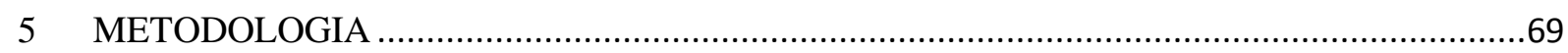

5.1 Modelo conceitual simplificado do método aplicado ......................................................69

5.2 Seleção das tecnologias simuladas ............................................................................

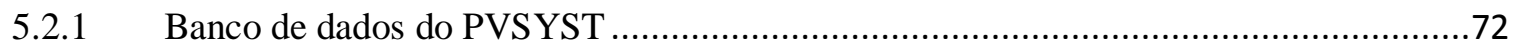

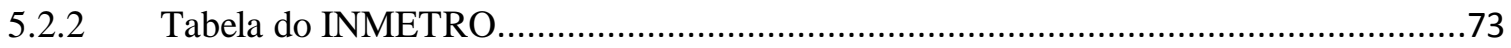

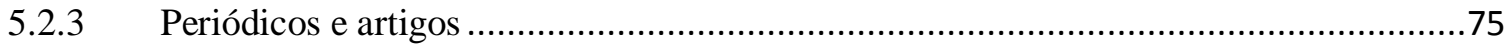

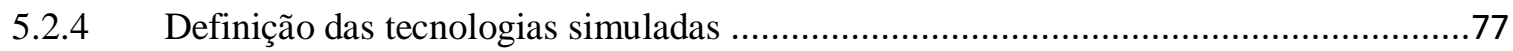

5.3 Definições básicas do sistema fotovoltaico (FV) ...........................................................79

5.3.1 Determinação das bases conceituais do projeto ...................................................... 80

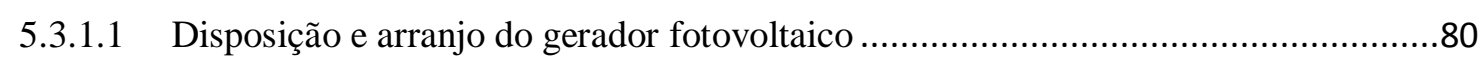

5.3.2 Definição das variáveis fixas do sistema fotovoltaico ............................................... 82

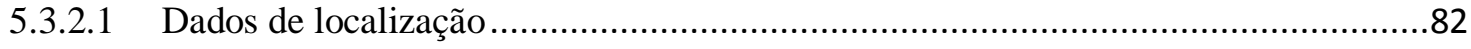

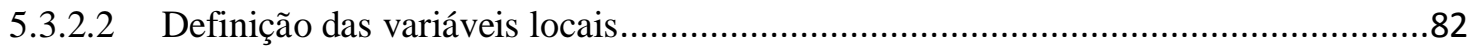

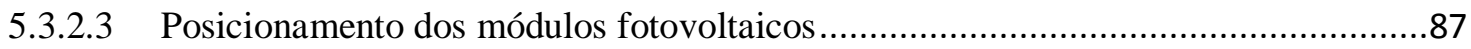

5.3.3 Definição das variáveis específicas de cada tecnologia fotovoltaica ............................91

5.3.3.1 Fator modificador do ângulo de incidência ........................................................91

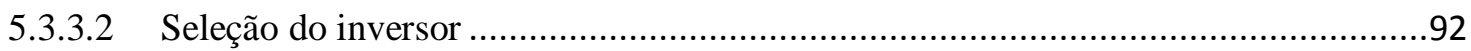

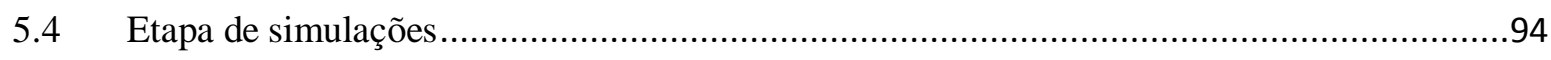

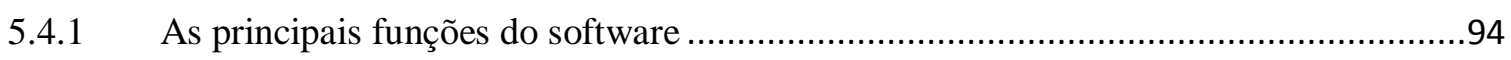

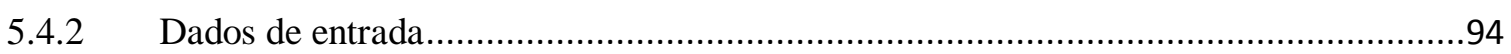




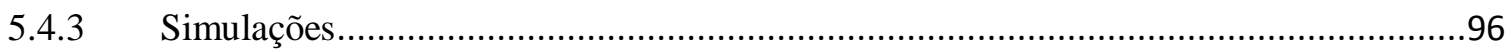

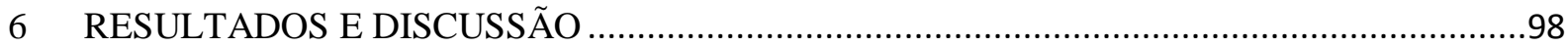

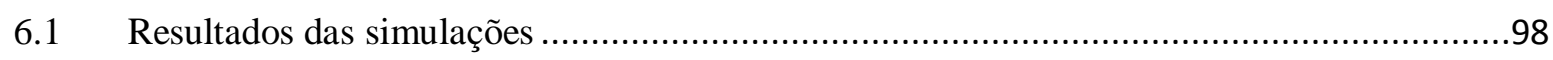

6.1.1 Diagrama funcional e resumo dos resultados .......................................................98

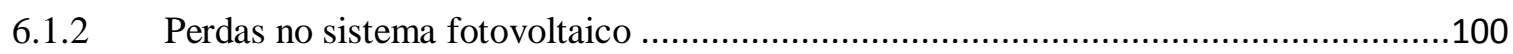

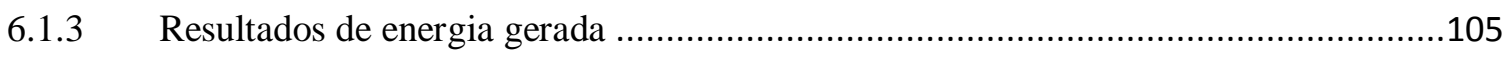

6.1.4 Comportamento da energia gerada em função da resposta espectral ..........................110

6.2 Índice de degradação das células .............................................................................116

6.3 Eficiência e degradação das tecnologias fotovoltaicas ....................................................117

6.4 Eficiência e ganho de energia gerada no inverno …......................................................118

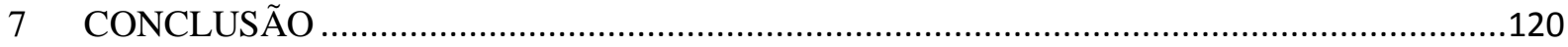

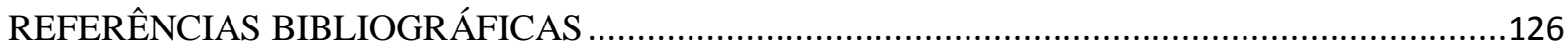

APÊNDICE A - Resultados das simulações - Energia anual gerada por tecnologia ..................133

APÊNDICE B - Resultados das simulações - Perdas anuais no sistema fotovoltaico ................134

APÊNDICE C - Resultados das simulações - Energia mensal gerada por tecnologia ...............135

APÊNDICE D - Energia gerada por estação do ano e por tecnologia .......................................136

APÊNDICE E - Densidade de energia gerada por estação e por tecnologia .............................137

APÊNDICE F - Participação e variação da energia gerada por estação e por grupo de tecnologia .138

APÊNDICE G - Relação entre a densidade de energia gerada (Earray) e o índice de degradação dos módulos

APÊNDICE H - Relação entre a densidade de energia gerada (Earray) e sua variação entre as estações verão-inverno

ANEXO A - Tabela de eficiência de células solares (Solar cell efficiency tables - version 48) ....141

ANEXO B - Tabela de eficiência de células solares (Solar cell efficiency tables - version 48).....142

ANEXO C - Gráfico da evolução de eficiência de células $N R E L$ 


\section{INTRODUÇÃO}

No Brasil, a energia elétrica gerada é proveniente de uma matriz com predominância em usinas hidrelétricas com reservatório (UHE), cuja participação é de 64,4\% ${ }^{1}$ (BOLETIM DE INFORMAÇÕES DE GERAÇÃO, 2016)². Nos últimos anos os níveis médios anuais dos reservatórios das usinas hidrelétricas vêm caindo em função dos baixos índices pluviométricos nessas localidades, atingindo níveis críticos e não apresentando possibilidades de recuperação a curto ou médio prazo. A Figura 1.1 mostra a evolução da energia armazenada mensal (EAR) ${ }^{3}$ do subsistema Sudeste/Centro-Oeste (SE/CO), no período de janeiro de 2012 a 31 de dezembro de 2016 (BOLETIM MENSAL DE MONITORAMENTO DO SISTEMA..., 2016) ${ }^{4}$.

Figura 1.1 - Evolução do nível dos reservatórios das usinas hidrelétricas do subsistema SE/CO

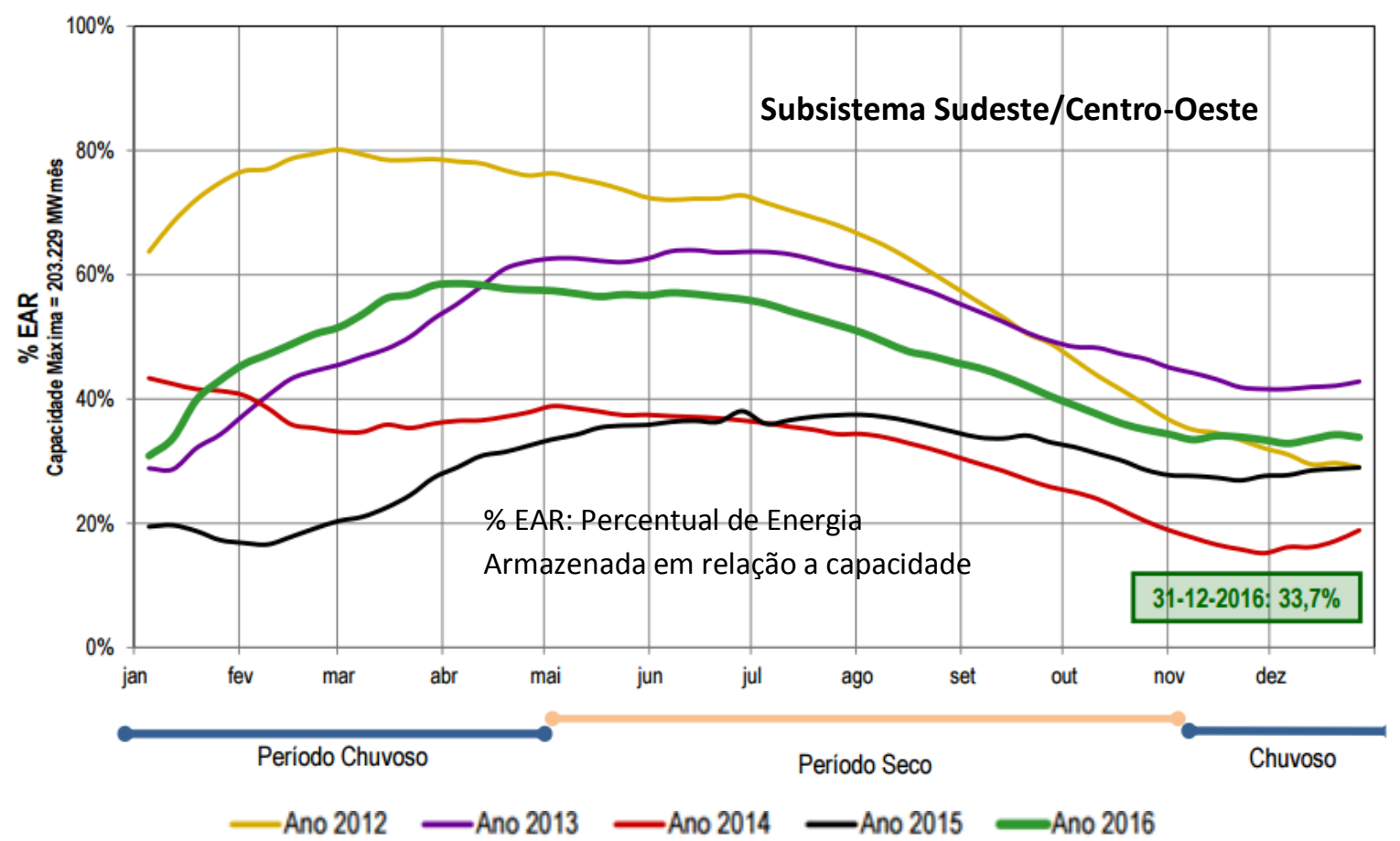

Fonte: Ministério de Minas e Energia (MME, 2016)

\footnotetext{
${ }^{1}$ Participação na matriz elétrica. Inclui usinas instaladas nos sistemas isolados e de autoprodução, não inclui a parcela de importação de Itaipu não consumida pelo sistema elétrico paraguaio. Registro de dezembro de 2016.

2 BIG [da] Agencia Nacional de Energia Elétrica (ANEEL). Mensal.

${ }^{3}$ EAR: índice de Energia Armazenada por Região - mede o nível dos reservatórios das UHE (ONS).

${ }^{4}$ Boletim mensal de monitoramento do Sistema Elétrico Brasileiro [da] Secretaria de Energia Elétrica [do] Ministério de Minas e Energia (MME).
} 
Pode-se notar claramente na Figura 1.1 a tendência de queda dos níveis dos reservatórios ano a ano, com exceção do ano de 2016, mas mesmo assim fechando o ano em 33,7\% da capacidade de energia armazenada. Observa-se também que o ciclo úmido recupera parcialmente os níveis dos reservatórios para garantir o atendimento ao consumo de energia elétrica durante o período seco. No entanto, esses volumes de reposição nos anos de 2014 e 2015 foram muito abaixo do normal.

Essa tendência de queda propicia um aumento na participação de usinas termelétricas convencionais (UTE) ${ }^{5}$ na matriz de geração elétrica brasileira para atendimento ao consumo de energia demandada: o que antes era de 13,3\% em 2012 passando para 20,0\% em 2013, 29,0\% em 2014, 29,5\% em 2015 e chegando a 28,8\% em 2016 (BOLETIM MENSAL DE MONITORAMENTO DO SISTEMA... , 2016). Esse fato vem ocasionando um aumento significativo do preço da tarifa ao consumidor, na faixa de $18,6 \%$ a $66,5 \%$ só em 2015 , dependendo da Concessionária local (COSTA M. , 2015) ${ }^{6}$. Somem-se a isso, os aumentos nas contas de energia elétrica dos consumidores relativos à revisão tarifária extraordinária ${ }^{7} \mathrm{e}$ o início da vigência das bandeiras tarifárias onerando em até R \$3,50/100 Quilowatts-hora (KWh) consumido (CRAIDE, 2017) ${ }^{8}$.

Considerando a problemática dos reservatórios das UHEs e a relevância do impacto na conta do consumidor, são necessárias ações emergenciais que apontem para as alternativas de geração de energia elétrica por fontes não hídricas e ambientalmente mais corretas do que as UTEs, como é o caso das usinas solares.

Outro aspecto importante: o modelo do sistema elétrico brasileiro apresenta uma arquitetura complexa com longas redes de transmissão de energia interligando as usinas de geração (padrão de geração centralizada) e conectando-as às várias redes de distribuição dos subsistemas. Denominada de Sistema Interligado Nacional (SIN), responde pelo fornecimento de 98,3\% da energia elétrica do país, segundo o Operador Nacional do Sistema Elétrico (ONS, 2015). Esse modelo torna o sistema suscetível às perdas técnicas, frequentes interrupções no fornecimento de energia e às causas naturais e climáticas.

Além disso, o fator de simultaneidade de demanda (pico de potência instantânea dos consumidores) gera ociosidades momentâneas em certos trechos da rede elétrica, enquanto que em áreas de concentração de consumidores, como em zonas urbanas ou industriais, há um

\footnotetext{
${ }^{5}$ Inclui UTE de Gás Natural, Biomassa, Petróleo, Carvão e Nuclear.

${ }^{6}$ Machado da Costa [do] Jornal A Folha de S. Paulo, 7/2/15. "Conta de luz deve subir, em média, 42\% no ano".

${ }^{7}$ RTE: inclui revisão orçamentária da Conta de Desenvolvimento Energético, aumento dos preços de energia de Itaipu (devido falta de chuva), reflexos dos preços do último leilão e ingresso de novas cotas de energia.

${ }^{8}$ Agencia Brasil EBC. 14 Fev. 2017.
} 
déficit de energia disponibilizada, requerendo manobras de equipamentos em campo que nem sempre são feitos em curto tempo.

A adoção de um modelo baseado em geração distribuída de energia elétrica é visto como uma solução mais adequada, favorecendo o balanço energético no sistema, além de contribuir com o atendimento ao crescimento da demanda e a redução de investimentos para ampliação de linhas de transmissão.

Outro aspecto importante nesse contexto está relacionado ao tipo de fonte para abastecer o modelo de geração distribuída de energia elétrica.

A participação de fontes solares fotovoltaicas na matriz elétrica mundial mostrou uma evolução considerável na última década em função do aumento de eficiência, da queda dos custos dos componentes ${ }^{9}$ e das iniciativas de incentivo ao setor em cada país. Esse fato, porém, foi amenizado nos últimos anos nos países europeus e nos EUA em função das crises econômicas. Contudo, o ano de 2014 mostrou uma recuperação do mercado americano na tecnologia solar e um crescimento do mercado asiático, liderado pela China e o Japão, ambas apoiadas em uma política baseada na tarifa Feed-in ${ }^{10}$.

Segundo a European Photovoltaic Industry Association (EPIA, 2014) ${ }^{11}$, a capacidade instalada mundial em 2012 que era de 100,5 Gigawatts-pico (GWp) passou para 138,9 GWp em 2013. O ano de 2014 registrou mais $40 \mathrm{GWp}$ de novos sistemas fotovoltaicos, atingindo o patamar global de 178,4 GWp de capacidade instalada (SOLAR POWER EUROPE, 2015) ${ }^{12}$, chegando a 229,3 GWp em 2015 e com uma estimativa de crescimento médio anual de $22 \%$ até 2020 (SOLAR POWER EUROPE, 2016) $)^{13}$.

No território brasileiro a capacidade instalada de sistemas fotovoltaicos chegou a apenas 80 Megawatts-pico (MWp) em dezembro de 2016 (BOLETIM MENSAL DE MONITORAMENTO DO SISTEMA..., 2016) ${ }^{14}$. A Figura 1.2 mostra a pequena participação das fontes solares fotovoltaicas na matriz de geração elétrica brasileira, cuja capacidade atingiu 150,4 GW em dezembro de 2016.

\footnotetext{
${ }^{9}$ Redução de $75 \%$ do custo de sistemas fotovoltaicos nos últimos 10 anos (SOLAR POWER EUROPE, 2015).

${ }^{10}$ Mecanismo governamental destinado a incentivar a geração de energia por fontes renováveis, baseado em contratos de longo prazo e no custo de geração de cada tecnologia (WIKIPEDIA, 2015).

${ }^{11}$ Global Market Outlook - for Photovoltaics 2014-2018. Sweden, 2014.

12 Global Market Outlook for Solar Power 2015-2019. Belgium, 2015.

${ }^{13}$ Global Market Outlook for Solar Power 2016-2020 - Webinar. Belgium, 2016.

${ }^{14}$ Inclui os sistemas em geração distribuída enquadradas na RN 482/2012.
} 


\section{Figura 1.2 - Matriz de capacidade instalada de geração de energia elétrica do Brasil}

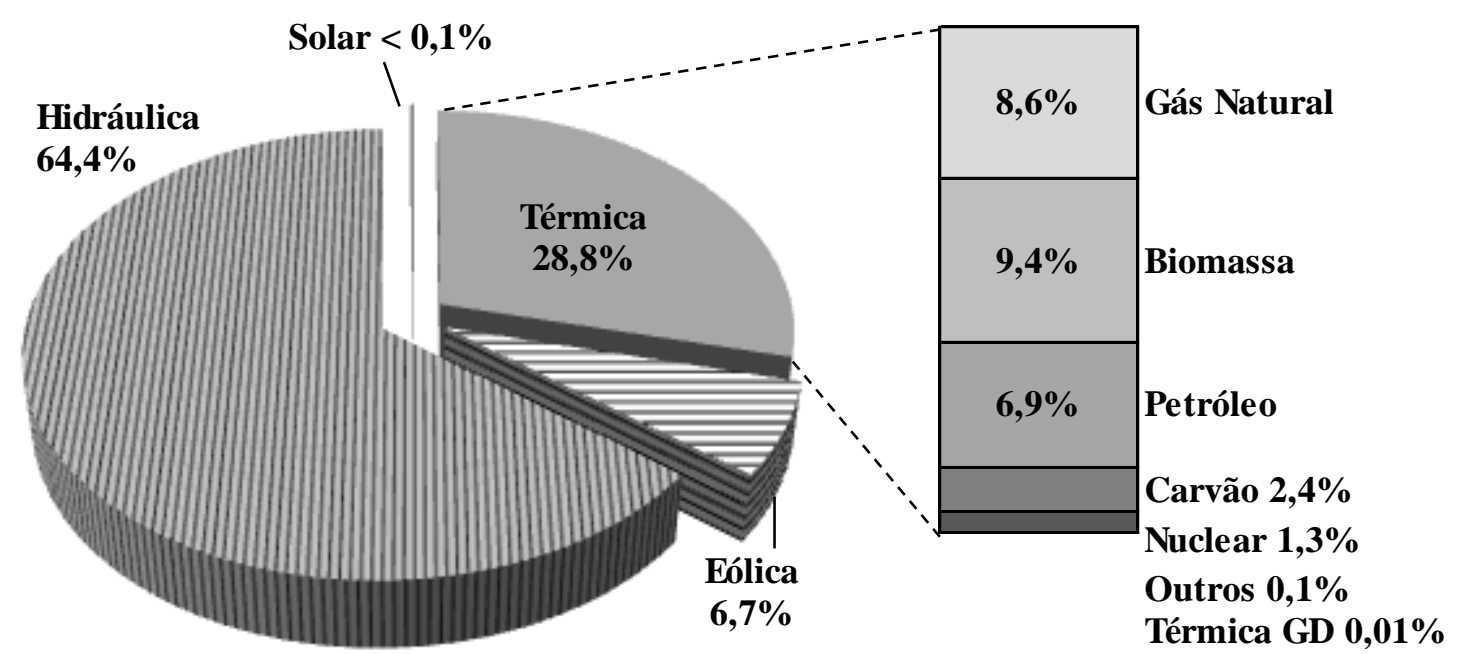

Fonte: Próprio autor. Base nos dados da ANEEL (2016).

A magnitude relativamente pequena de instalações fotovoltaicas no Brasil se deve a vários fatores como: preços elevados dos componentes do sistema quase todos importados, falta de política de incentivos fiscais mais agressivas e de opções para financiamento a taxas atrativas, e ausência de um modelo adequado para comercialização de energia. Somem-se a isso os aspectos culturais baseados fortemente na fonte hidrelétrica e ao pouco conhecimento por parte do consumidor sobre a fonte. Esse panorama criou uma barreira para a inserção dessa tecnologia no país, não permitindo progredir para um nível de economia de escala que resultasse em uma redução de custos dos projetos.

No entanto, vai se tornando cada vez mais atrativa a exploração da energia fotovoltaica no Brasil para aproveitamento do alto nível de potencial solar no território por conta de sua localização geográfica ${ }^{15}$, mais em função das questões ambientais e de capacidade de geração hídrica do que da queda dos preços dos componentes da usina ocorrida nos anos mais recentes no mercado mundial. Embora a condição econômica do país não seja favorável neste momento, alguns elementos serviram como componentes motivadores no sentido de alavancar a participação dessas fontes na matriz elétrica brasileira, com a atuação inicial das instituições governamentais e entidades de classe rumo à regulamentação dessa tecnologia.

As metodologias usualmente praticadas no dimensionamento de sistemas fotovoltaicos conectados à rede são, em sua maioria, voltadas às aplicações com painéis rígidos de células

\footnotetext{
${ }^{15}$ A irradiação solar média diária sobre o território brasileiro é de $4.500 \mathrm{Wh} / \mathrm{m} 2$ a $6.300 \mathrm{Wh} / \mathrm{m} 2$. O nível é $40 \%$ superior ao da Alemanha, um dos países com maior capacidade instalada de painéis fotovoltaicos no mundo (GRANDIN, 2013).
} 
de silício cristalino, tecnologia atualmente dominante no mercado fotovoltaico mundial (ESPOSITO; FUCHS, 2013).

Os módulos fotovoltaicos de silício cristalino (ou de primeira geração) respondem por cerca de $90 \%$ do mercado global, enquanto que a tecnologia de filmes finos $(T F)$ representa apenas $10 \%$ do mercado. Essa última (de segunda geração) pode ser subdividida em três tipologias sendo 5\% correspondente às células de telureto de cádmio (CdTe), de amorfo hidrogenado (aSi: $\mathrm{H}$ ) com $2 \%$ e de disseleneto de cobre, índio e gálio (CIGS) com outros 2\%. Já os concentradores fotovoltaicos (CPV) participam com menos de 1\%. Segundo a International Energy Agency $(I E A, 2014)^{16}$, os sistemas de geração distribuída representam aproximadamente $60 \%$ do mercado global, enquanto os sistemas centralizados em torno de $40 \%$, e os sistemas isolados (Off-grid) menos que 1\%. A Figura 1.3 mostra a participação no mercado mundial.

\section{Figura 1.3 - Participação das tecnologias fotovoltaicas no mercado mundial}

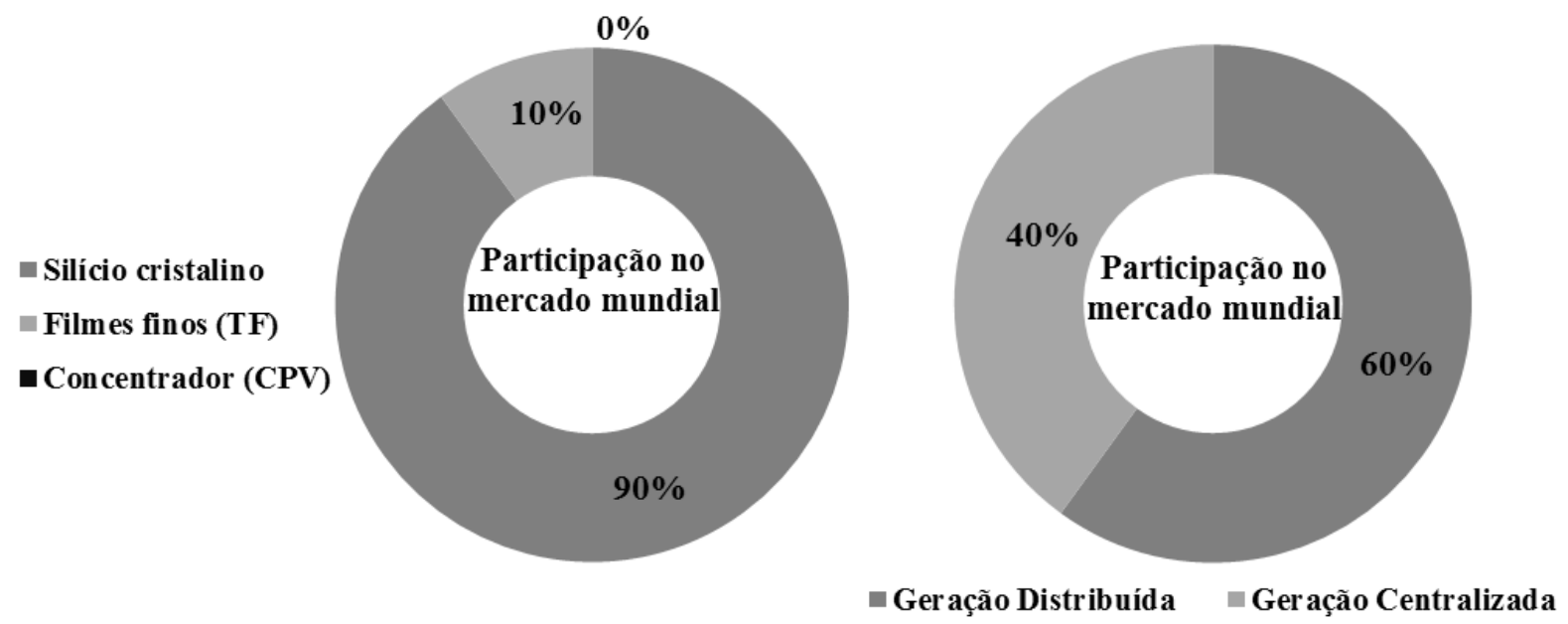

Fonte: Próprio autor (2015). Base nos dados de Technology Roadmap 2014 edition. IEA (2014)

Muito embora a eficiência dos módulos com células de silício, comercializadas no mercado mundial, tenha demonstrado uma evolução nos últimos dez anos, a crescente demanda por uma solução com melhor relação custo-benefício e ao mesmo tempo com menor ocupação de áreas horizontais, propulsionou um rápido desenvolvimento de novas tecnologias fotovoltaicas.

Segundo Gunther $(2015)^{17}$, módulos de filme fino chegam atualmente a apresentar, em alguns casos, desempenhos melhores que os de silício cristalino com o mesmo custo, principalmente

\footnotetext{
${ }^{16}$ Technology Roadmap 2014 edition. Solar Photovoltaic Energy. France.

${ }^{17}$ Are Glowing Reports of New Solar Cell Material Mostly Hype? Mar. 2015 (GUNTHER, 2015).
} 
aqueles compostos por elementos calcogêneos como o telureto de cádmio (CdTe) ou o disseleneto de cobre, índio e gálio (CIGS).

As células fotovoltaicas emergentes de película fina (ou de terceira geração) utilizam tecnologias com grande potencial de superar o limite Shockley-Queisser ${ }^{18}$, e surgem para atender ao apelo do mercado com menores custos relativos aos materiais e ao processo produtivo, maiores eficiências e flexibilidade de aplicação. Essa geração inclui a célula solar do tipo Dye Sensitized (DSSC), a célula fotovoltaica orgânica $(O P V)$ e a célula Perovskite. As características de flexibilidade, ajuste de cores e de nível de transparência e possibilidade de cores diversificadas, levam a uma fácil adaptação para integração nas edificações. No entanto, a maioria dessas células ainda se encontra em fase de desenvolvimento ou de pesquisas experimentais, não fornecendo ainda um nível de confiabilidade suficiente para aplicações práticas.

O conceito de Building Integrated Photovoltaic (BIPV), ou sistema fotovoltaico integrado à edificação, vem contribuir no atendimento aos requisitos de desempenho do setor de construção civil no que tange a sustentabilidade e eficiência energética, além de favorecer no balanço energético brasileiro dentro do contexto do consumo de energia elétrica.

A flexibilidade e versatilidade de aplicação proporcionada pelos filmes finos torna essa tecnologia um grande aliado do conceito BIPV, como elemento alternativo na parte estrutural do envelopamento ou arquitetônico de um edifício, como telhados, fachadas, revestimentos de paredes, dispositivos de sombreamento ou janelas.

No entanto, sua aplicação como elemento integrado à estrutura do edifício, substituindo as vedações ou as fachadas, deve ser previamente avaliada, confrontando-se as características técnicas dos fabricantes com os requisitos das normas e regulamentações brasileiras, no que tange a Engenharia e segurança na construção civil. Diante disso, a adoção de vidros fotovoltaicos em substituição aos vidros convencionais das edificações surge como alternativa mais simples e com maiores chances de aplicação neste momento.

Por outro lado, outro conceito denominado Building Attached (ou Adapted) Photovoltaic $(B A P V)$, ou sistema fotovoltaico anexado (ou adaptado) à edificação, vem ganhando força no mercado mundial, pois permite o aproveitamento da área vertical disponível do edifício (fachadas cegas) sem a necessidade de interferência significativa na parte estrutural da construção. Além disso, possibilita a aplicação de tecnologias fotovoltaicas mais maduras, como aquelas de primeira e de segunda geração.

\footnotetext{
${ }^{18}$ Máxima eficiência teórica de uma célula solar com junção p-n para conversão em energia.
} 


\section{JUSTIFICATIVA}

O momento crítico por que tem passado o sistema elétrico brasileiro nos últimos anos, tanto no aspecto de abastecimento quanto no de qualidade de fornecimento, vem sinalizando para uma necessidade de mudança de seu modelo. Alinhado aos fatores de sustentabilidade, de crescimento habitacional e ambiental, e potencializado pelo nível de disponibilidade de seu fomento, o modelo de geração distribuída de eletricidade com fonte solar fotovoltaica vem se apresentando como uma solução cada vez mais atrativa no País. Contudo, a crescente evolução da participação de domicílios unifamiliares em edifícios, que dispõem de menores áreas horizontais per capita, exige alternativas de arranjos verticais sem, no entanto afetar significativamente o seu desempenho.

São comentadas a seguir as principais razões que motivaram o tema desta dissertação.

\subsection{O cenário do setor elétrico brasileiro sob dois pontos de vista}

O primeiro relativo aos níveis hidrológicos dos reservatórios das usinas hidrelétricas, suscetíveis às variações climáticas e aos níveis pluviométricos, que respondem por $64,4 \%$ da matriz de geração de eletricidade no País. Nos últimos anos esses níveis vêm caindo em função dos baixos índices pluviométricos, atingindo patamares críticos e não apresentando possibilidades de recuperação a curto ou médio prazo. Esse fato vem propiciando um aumento significativo no preço final ao consumidor. Portanto, são necessárias ações emergenciais que apontem para as alternativas de geração de energia elétrica por fontes não hídricas e ambientalmente mais corretas. A fonte solar fotovoltaica é um desses casos.

O outro ponto de vista é relacionado ao modelo do sistema elétrico brasileiro. O modelo apresenta uma arquitetura complexa e linhas de transmissão extensas (conceito de geração centralizada), causando perdas técnicas, frequentes interrupções e maior suscetibilidade frente às causas naturais e climáticas. A adoção de um modelo baseado em geração distribuída de energia elétrica é visto como uma solução mais adequada, favorecendo o balanço energético no sistema, além de contribuir com o atendimento ao crescimento da demanda e a redução de investimentos para ampliação de linhas de transmissão. 


\subsection{Alto nível de potencial solar no território brasileiro}

O Brasil possui alto nível de potencial solar por conta de sua localização geográfica, cuja irradiação ${ }^{19}$ solar anual em seu menor nível é $40 \%$ superior ao maior nível da Alemanha, país que tem a maior capacidade instalada no mundo (GRANDIN, 2013).

Estudo recente de âmbito mundial elaborado pela Solar Power Europe $(2016)^{20}$ mostrou, tanto no cenário otimista como no cenário conservador, uma tendência de crescimento mundial da tecnologia entre 2016 e 2020, conforme a Figura 2.1.

\section{Figura 2.1 - Perspectiva do mercado mundial fotovoltaico}

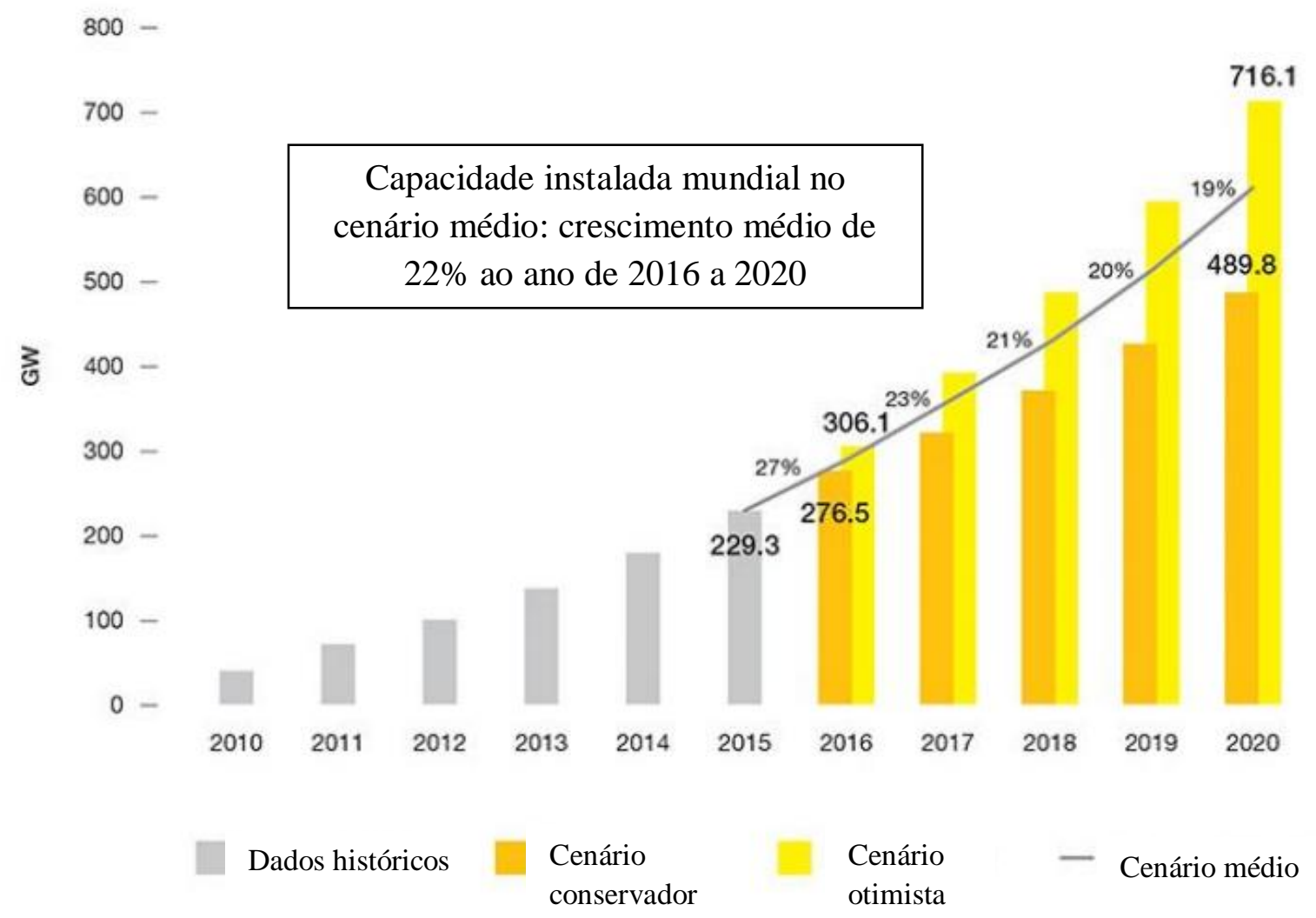

Fonte: SOLAR POWER EUROPE (2016). Tradução nossa.

O cenário conservador leva em conta a queda dos mercados europeus e dificuldade de estabelecer novos mercados duráveis em países emergentes. Já o cenário otimista considera o mercado em baixa na Europa e crescente nas regiões emergentes, em que o Brasil se enquadra.

\footnotetext{
${ }^{19}$ Irradiação solar é a quantidade de radiação solar incidente por unidade de área; ou a irradiância integrada em um intervalo de tempo, cuja unidade é watt hora (ou dia, mês) por metro quadrado $\left(\mathrm{Wh} / \mathrm{m}^{2}\right)$.

${ }^{20}$ Global Market Outlook - for Solar Power 2016-2020. Sweden, 2016.
} 


\subsection{A inovação na construção de edificações sob a ótica do consumidor}

A Câmara Brasileira da Indústria da Construção Civil (CBIC, 2014) ${ }^{21}$ contratou uma pesquisa nacional relativa à inovação na construção civil no Brasil sob a ótica do consumidor, divulgada em março de 2014. Esse trabalho teve como objetivo avaliar a percepção dos consumidores com relação às inovações tecnológicas nos imóveis residenciais, focalizando a inovação do ponto de vista da demanda. O resultado mostrou que $81,9 \%$ dos entrevistados aprovam as inovações nos imóveis, sendo que o aspecto de economia foi o item mais destacado com 30,2\%. Na escolha do item mais importante, os principais resultados relacionados à economia foram: racionalização do uso de energia $(21,4 \%)$, racionalização do uso de água $(12,1 \%)$, teto para geração de energia solar $(8,5 \%)$.

No Brasil, a taxa registrada de crescimento de moradias do tipo apartamento entre os anos de 2000 e 2010 (IBGE, 2013) ${ }^{22}$ foi de 43\%. Índice relevante se comparado ao de crescimento de domicílios nos próximos dez anos previsto em 17,2\% (EPE, 2013) ${ }^{23}$.

Nota-se a importância cada vez maior das tecnologias fotovoltaicas integradas ou adaptadas aos edifícios para contribuir não somente com a solução do setor elétrico e o fator de desempenho, mas também no atendimento aos anseios do consumidor.

\subsection{O panorama tecnológico, regulatório e tributário brasileiro}

Embora o momento político-econômico do País não seja favorável, o novo modelo de geração fotovoltaica em geração distribuída vem contando com iniciativas de diversos agentes da cadeia. Alguns desses exemplos: a resolução normativa da ANEEL RN 482/2012 revisada pela RN 687/2015, a norma técnica brasileira NBR-5410 em revisão pelo Grupo de Estudos da Associação Brasileira de Normas Técnicas (ABNT, 2015) visando incorporar aspectos inerentes à tecnologia fotovoltaica, os programas de incentivos fiscais (IPI, ICMS) para componentes do sistema e de isenção de ICMS sobre a parcela de energia injetada à rede $\left(\right.$ CONFAZ, 2015) ${ }^{24}$, e os financiamentos em P,D\&I para aplicações de fontes alternativas de energia elétrica.

\footnotetext{
${ }^{21}$ Pesquisa nacional da Câmara Brasileira da Indústria da Construção: A Inovação na Construção Civil no Brasil sob a Ótica do Consumidor. Instituto Sensus, Mar. 2014

22 Instituto Brasileiro de Geografia e Estatística. Censo Demográfico 2010: Características da População e dos Domicílios - Resultados do Universo.

${ }^{23}$ Empresa de Pesquisa Energética. Nota Técnica DEA 28/13 - Projeção da demanda de energia elétrica para os próximos 10 anos (2014-2023). MME, dez. 2013.

${ }^{24}$ CONFAZ-Conselho Nacional de Política Fazendária, Convênio ICMS nº16 de 27 Abr. 2015.
} 
Vale ressaltar que o avanço da tecnologia no País tem sofrido uma aceleração maior nos últimos anos motivada pela problemática da matriz de geração elétrica.

\subsection{Tecnologias fotovoltaicas}

As metodologias usualmente praticadas no dimensionamento de sistemas fotovoltaicos são, em sua maioria, voltadas às aplicações com painéis rígidos de células de silício cristalino, tecnologia que corresponde a 90\% do mercado fotovoltaico mundial (ESPOSITO; FUCHS, 2013). Apesar da evolução efetiva de sua eficiência nos últimos dez anos, a crescente demanda por uma solução com melhor relação custo-benefício e ao mesmo tempo com menor ocupação de áreas horizontais, propulsionou um rápido desenvolvimento de novas tecnologias fotovoltaicas, dentre elas as de filme fino, já aplicadas mundialmente, e as de terceira geração que são mais recentes.

\subsection{Considerações gerais}

Diante do cenário apresentado, essa dissertação buscou contribuir com uma análise de desempenho energético com base em simulações para tomada de decisão técnica sobre as tecnologias mais adequadas de célula fotovoltaica para sistemas a serem instalados em fachadas de edifícios, sob os pontos de vista da geração de energia elétrica e eficiência do sistema. 


\section{OBJETIVOS}

\subsection{Objetivo geral}

O objetivo dessa dissertação foi realizar uma análise de desempenho energético com base em simulações, para tomada de decisão técnica sobre as tecnologias mais adequadas de célula fotovoltaica para sistemas a serem instalados em fachadas de edifícios, dentro do conceito de geração distribuída conectada à rede.

O método teve como fronteira o estudo aplicado a um edifício hipotético habitacional localizado no município de São Paulo. Em função de uma maior disponibilidade de dados técnicos, a pesquisa teve como foco as tecnologias fotovoltaicas de filme fino, de painéis rígidos de silício cristalino e de vidros fotovoltaicos semitransparentes.

\subsection{Objetivos específicos}

a) Análise e revisão das regulamentações e das normas técnicas brasileiras do setor, bem como dos principais conceitos e fundamentos técnicos envolvidos;

b) Definição do modelo conceitual do método aplicado para o desenvolvimento do trabalho;

c) Estudo das funcionalidades do software solar PVSYST;

d) Determinação das variáveis técnicas relevantes para efeito de simulação e obtenção dos dados de referência e seus acessos;

e) Investigação das características e propriedades técnicas de cada tecnologia fotovoltaica envolvida neste trabalho: silício cristalino, filme fino e vidros fotovoltaicos;

f) Estabelecimento dos critérios de seleção de módulos fotovoltaicos relacionados às tecnologias simuladas neste trabalho;

g) Pesquisa exploratória de fabricantes, em âmbito mundial, e seleção dos modelos de módulos fotovoltaicos atualmente comercializados e que atendessem aos critérios estabelecidos;

h) Determinação do modelo de edifício padrão para efeito de simulação e dos arranjos fotovoltaicos dispostos em sua fachada;

i) Realização de simulações para cada tecnologia de célula e análise de seus resultados, com comparação de desempenho entre elas. 


\section{REVISÃO BIBLIOGRÁFICA}

\subsection{Revisão das normas e regulamentações técnicas e tributárias}

A Resolução Normativa (RN) 482/2012 da Agência Nacional de Energia Elétrica (ANEEL), trata, dentre outros assuntos, das condições para o acesso de geração distribuída aos sistemas de distribuição de energia elétrica e do sistema de compensação de energia elétrica.

A primeira iniciativa no País abrangendo as regulamentações e normas técnicas relativas aos sistemas fotovoltaicos e ao sistema de geração distribuída de energia elétrica, nos aspectos que impactaram nas diretrizes e na forma de condução no desenvolvimento deste trabalho. A regulamentação relativa à geração distribuída (RN 482/2012) sofreu revisão conforme ditada pela RN 687 de 24 de novembro de 2015 e com vigência a partir de março de 2016, sendo que uma das principais alterações veio de encontro com a aplicação da base desta simulação: um edifício, enquadrando seus usuários como "unidades integrantes de um empreendimento de múltiplas unidades consumidoras", conforme item II do Art. $6^{\circ}$ da referida resolução.

Os principais pontos abordados nesta revisão ${ }^{25}$, e que estão relacionados ao tema desta dissertação, são contextualizados a seguir. A Tabela 4.1 fornece uma visão resumida destes pontos técnicos, adicionando o aspecto tributário inerente ao assunto.

Tabela 4.1 - Resumo das revisões da RN 687/2015 e tributárias

\begin{tabular}{|c|c|c|c|c|}
\hline Item & Aspecto & Texto anterior & Revisão & $\begin{array}{c}\text { Situação e } \\
\text { impacto no tema }\end{array}$ \\
\hline \multirow[t]{2}{*}{1} & \multirow[t]{2}{*}{$\begin{array}{l}\text { Incidência de } \\
\text { impostos na } \\
\text { geração } \\
\text { distribuída (GD) }\end{array}$} & $\begin{array}{l}\text { Convênio ICMS } 6 \\
\text { (CONFAZ, 2013): } \\
\text { incidência de ICMS } \\
\text { sobre toda a energia } \\
\text { consumida sem } \\
\text { compensar a } \\
\text { energia injetada }\end{array}$ & $\begin{array}{c}\text { Convênio ICMS } 16 \\
\text { (2015): incidência de } \\
\text { ICMS somente sobre a } \\
\text { diferença positiva do } \\
\text { balanço de energia elétrica } \\
\text { para Goiás, Pernambuco e } \\
\text { São Paulo }\end{array}$ & $\begin{array}{l}\text { Em vigor. } \\
\text { Influi no balanço } \\
\text { econômico de } \\
\text { energia elétrica }\end{array}$ \\
\hline & & $\begin{array}{l}\text { PIS }^{26} \text { e COFINS } \\
\text { incidem em valor } \\
\text { integral: regime não } \\
\text { cumulativo }(9,25 \%)\end{array}$ & $\begin{array}{l}\text { Isenção destes tributos } \\
\text { sobre a parcela } \\
\text { correspondente à energia } \\
\text { injetada na rede }\end{array}$ & $\begin{array}{l}\text { Em vigor. } \\
\text { Impacta na } \\
\text { viabilidade }\end{array}$ \\
\hline & & & \multicolumn{2}{|c|}{ Continua } \\
\hline \multicolumn{5}{|c|}{$\begin{array}{l}{ }^{25} \text { Resolução Normativa n }{ }^{\circ} .687 \text { de } 24 \text { de Novembro de } 2015 \text {. Altera a Resolução Normativa no } 482 \text {, de } 17 \text { de } \\
\text { abril de 2012, e os Módulos } 1 \text { e } 3 \text { dos Procedimentos de Distribuição - PRODIST (ANEEL, 2015). } \\
\text { PIS (Lei Complementar n }{ }^{\circ} 7 / 1970 \text { ): contribuição tributária de caráter social, que tem como objetivo financiar o } \\
\text { pagamento aos trabalhadores do seguro-desemprego, abono e participação na receita dos órgãos e entidades } \\
\text { (SITE CONTABIL, 2015). }\end{array}$} \\
\hline
\end{tabular}




\begin{tabular}{|c|c|c|c|c|}
\hline Item & Aspecto & Texto anterior & Revisão & $\begin{array}{c}\text { Situação e } \\
\text { impacto no tema }\end{array}$ \\
\hline 2 & $\begin{array}{l}\text { Contexto de } \\
\text { micro e } \\
\text { minigeração } \\
\text { distribuída }\end{array}$ & $\begin{array}{l}\text { Limitava a potência } \\
\text { para micro }(100 \\
\mathrm{kW}) \text { e minigeração } \\
(1 \mathrm{MW})\end{array}$ & $\begin{array}{c}\text { Limite para micro }(75 \mathrm{~kW}) \\
\text { e minigeração }(5 \mathrm{MW}) \\
\text { exceto fontes hídricas } \\
(3 \mathrm{MW})\end{array}$ & $\begin{array}{l}\text { Em vigor. } \\
\text { Enquadramento } \\
\text { do sistema }\end{array}$ \\
\hline 3 & $\begin{array}{l}\text { Contexto da } \\
\text { compensação de } \\
\text { energia: } \\
\text { titularidade da } \\
\text { unidade } \\
\text { consumidora }\end{array}$ & $\begin{array}{l}\text { Permitia compensar } \\
\text { apenas em outra } \\
\text { unidade com o } \\
\text { mesmo CPF ou } \\
\text { CNPJ }\end{array}$ & $\begin{array}{l}\text { Permite utilizar os créditos } \\
\text { nas unidades de um } \\
\text { empreendimento com } \\
\text { múltiplas unidades } \\
\text { consumidoras (EMUC) }\end{array}$ & $\begin{array}{l}\text { Em vigor. } \\
\text { Possibilita a } \\
\text { aplicação em } \\
\text { condomínios }\end{array}$ \\
\hline 4 & $\begin{array}{l}\text { Contexto da } \\
\text { potência instalada } \\
\text { da central } \\
\text { geradora } \\
\text { (EMUC) }\end{array}$ & Não mencionava & $\begin{array}{l}\text { Limitada na potência } \\
\text { disponibilizada pela } \\
\text { distribuidora para o } \\
\text { empreendimento }\end{array}$ & $\begin{array}{l}\text { Em vigor. } \\
\text { Limita a potência } \\
\text { global do gerador } \\
\text { fotovoltaico }\end{array}$ \\
\hline 5 & $\begin{array}{l}\text { Contexto da } \\
\text { solicitação de } \\
\text { acesso à } \\
\text { distribuidora } \\
\text { (EMUC) }\end{array}$ & Não mencionava & $\begin{array}{l}\text { Instrumento jurídico de } \\
\text { compromisso de } \\
\text { solidariedade entre os } \\
\text { integrantes }\end{array}$ & $\begin{array}{c}\text { Em vigor. Somente } \\
\text { impacto } \\
\text { documental }\end{array}$ \\
\hline 6 & $\begin{array}{l}\text { Contexto dos } \\
\text { custos de } \\
\text { eventuais } \\
\text { melhorias ou } \\
\text { reforços no } \\
\text { sistema de } \\
\text { distribuição }\end{array}$ & $\begin{array}{l}\text { Participação do } \\
\text { consumidor }\end{array}$ & $\begin{array}{c}\text { Microgeração: } \\
\text { responsabilidade da } \\
\text { distribuidora (exceto para } \\
\text { geração compartilhada). } \\
\text { Minigeração: participação } \\
\text { do consumidor }\end{array}$ & $\begin{array}{l}\text { Em vigor. } \\
\text { Reduz os custos de } \\
\text { implantação }\end{array}$ \\
\hline 7 & $\begin{array}{c}\text { Custo de } \\
\text { adequação do } \\
\text { sistema de } \\
\text { medição para GD }\end{array}$ & $\begin{array}{l}\text { Investimento era do } \\
\text { consumidor }\end{array}$ & $\begin{array}{l}\text { Microgeração: } \\
\text { responsabilidade da } \\
\text { distribuidora. } \\
\text { Minigeração: } \\
\text { responsabilidade do } \\
\text { consumidor }\end{array}$ & $\begin{array}{l}\text { Em vigor. } \\
\text { Reduz os custos de } \\
\text { implantação }\end{array}$ \\
\hline
\end{tabular}

Fonte: Próprio autor com base nas informações da revisão RN 687/2015 (2016).

\subsubsection{Incidência de impostos}

O Conselho Nacional de Política Fazendária (CONFAZ) aprovou em 2013 o Convênio ICMS 6, que estabelecia a aplicação do Imposto sobre Circulação de Mercadorias e Serviços (ICMS) sobre toda a energia consumida sem considerar qualquer compensação de energia produzida pelo micro ou minigerador.

Revendo alguns conceitos, o CONFAZ estabeleceu em abril de 2015, o Convênio ICMS n ${ }^{\circ}$. 16, autorizando originalmente as unidades federadas dos Estados de Goiás, Pernambuco e São 
Paulo a concederem isenção do ICMS sobre a diferença positiva entre a energia elétrica consumida e a injetada dos micro ou minigeradores conectados à rede. Caso a energia injetada na rede seja superior ao consumo, a base de cálculo é apenas o valor do custo de disponibilidade $^{28}$ (CONFAZ, 2015).

Além disso, havia a incidência dos tributos do Programa de Integração Social (PIS) e da Contribuição para o Financiamento da Seguridade Social (COFINS), praticada por todas as distribuidoras de energia elétrica, de $9,25 \%$ sobre o valor integral da fatura, sem ao menos descontar a parcela equivalente à energia gerada pelo consumidor e injetada na rede.

No dia 07 de outubro de 2015 o Governo Federal publicou a Lei ${ }^{\circ} 13.169$ que trata da desoneração do PIS e do COFINS que incide sobre a geração distribuída de energia solar. A Lei reduziu a zero essas alíquotas incidentes sobre a energia elétrica ativa fornecida pela distribuidora ao consumidor, no montante correspondente à soma da energia injetada por ele na rede com os créditos de energia da própria unidade consumidora ou de outra unidade consumidora do mesmo titular $\left(\right.$ DOU $\left.^{29}, 2015\right)$. Essa desoneração foi mais um incentivo ao setor, aumentando a viabilidade para instalação de Sistemas de Geração de Energia Solar Fotovoltaica.

\subsubsection{Contexto de geração distribuída}

A RN 482/2012 definia como microgeração e minigeração distribuída as centrais geradoras de energia elétrica conectadas à rede de distribuição de unidades consumidoras com potências instaladas de até $100 \mathrm{KW}$ e $1 \mathrm{MW}$, respectivamente, ambas utilizando fontes baseadas em energia hidráulica, solar, eólica, biomassa ou cogeração qualificada.

Um ponto de discussão era relativo ao limite mínimo exigido de potência da central nos

Leilões de Energia de Reserva (LER) ${ }^{30}$ para contratação de energia no Ambiente de Contratação Regulada (ACR). Os empreendimentos de geração de menor porte, abaixo do limite de 5 MW de capacidade instalada, além de serem excluídos dos leilões regulados, também não se enquadravam no limite de geração distribuída estabelecido pela RN 482/2012.

\footnotetext{
${ }^{28}$ Valor equivalente a $30 \mathrm{kWh}$ (mono ou bifásico a 2 fios), $50 \mathrm{kWh}$ (bifásico a 3 fios) ou $100 \mathrm{kWh}$ (trifásico) para consumidores do grupo B (baixa tensão), conforme art. 98 da REN n 414/2010 (ANEEL, 2012).

${ }^{29}$ Diário Oficial da União (DOU): texto na Seção 1 . Art. $8^{\circ}$.

${ }^{30}$ Inciso II, $\$ 2^{\circ}$, Art. $3^{\circ}$, Portaria MME n ${ }^{\circ} 236$, de 30/5/2014.
} 
Face ao exposto, a revisão determinou o aumento do limite da potência instalada para $5 \mathrm{MW}$, exceto para central geradora hidrelétrica $(\mathrm{CGH})$, cujo limite legal ${ }^{31}$ para o registro na ANEEL é $3 \mathrm{MW}$.

Por outro lado, da potência instalada da central geradora de um empreendimento de múltiplas unidades consumidoras (EMUC) ficou limitada à potência disponibilizada pela distribuidora. Com base na capacidade nominal dos arranjos fotovoltaicos, os sistemas adotados nas simulações deste trabalho estão enquadrados como microgeração distribuída, com potências nominais menores do que este limite.

\subsubsection{Contexto da compensação de energia}

Outro aspecto revisado se relaciona à titularidade da unidade consumidora no processo de compensação de energia excedente injetada na rede. Na versão anterior somente era permitido ao consumidor compensar a energia injetada excedente apenas em unidades cujo titular tenha o mesmo Cadastro de Pessoa Física (CPF) ou Cadastro de Pessoa Jurídica (CNPJ). A partir dessa revisão, os créditos de energia puderam ser utilizados também em outras unidades consumidoras localizadas em áreas contíguas não necessariamente com a mesma titularidade, como ocorre em condomínios residenciais e comerciais, que podem ser caracterizados como uma comunhão de interesse de fato. Nesse caso, um edifício pode ser enquadrado como "empreendimento com múltiplas unidades consumidoras".

O inciso II do Art. $6^{\circ}$ da RN 687/2015 é citado abaixo:

[...] Podem aderir ao sistema de compensação de energia elétrica os consumidores responsáveis por unidade consumidora:

$[\ldots]$

II - integrante de empreendimento de múltiplas unidades consumidoras;

$[\ldots]$

Empreendimento com múltiplas unidades consumidoras (condomínios): caracterizado pela utilização da energia elétrica de forma independente, no qual cada fração com uso individualizado constitua uma unidade consumidora e as instalações para atendimento das áreas de uso comum constituam uma unidade consumidora distinta, de responsabilidade do condomínio, da administração ou do proprietário do empreendimento, com microgeração ou minigeração distribuída, e desde que as unidades consumidoras estejam localizadas em uma mesma propriedade ou em propriedades contíguas, sendo vedada a utilização de vias públicas, de passagem aérea ou subterrânea e de propriedades de terceiros não integrantes do empreendimento. [...] (ANEEL, 2015).

\footnotetext{
${ }^{31}$ Conforme $\S^{\circ}$ do art. $8^{\circ}$ da Lei n ${ }^{\circ} 9.074$, de 7/7/1995, com redação dada pela Lei 13.097, de 19/1/2015.
} 
A energia excedente do empreendimento de múltiplas unidades consumidoras (EMUC) deve ser rateada entre as unidades consumidoras, na proporção informada à distribuidora de energia elétrica.

\subsubsection{Custos do sistema de medição e de melhorias no sistema de distribuição}

O investimento para adequação do sistema de medição, equivalente a diferença entre o custo do medidor convencional e o do sistema bidirecional, recaía sobre qualquer consumidor que decidisse adotar a geração distribuída.

Em função de uma falta de padronização, há uma variedade de modelos de equipamentos adotados pelas distribuidoras voltados à medição em regime de compensação de energia. Este fato causa uma discrepância nos preços praticados que variam entre $\mathrm{R} \$ 80,00$ e $\mathrm{R} \$ 1.800,00$, segundo pesquisa ${ }^{32}$ elaborada pela ANEEL (2014).

A revisão da norma transferiu os custos do sistema de medição da microgeração distribuída para a responsabilidade da distribuidora, enquanto que para a minigeração o consumidor passou a participar dessas despesas, sustentado pelo fato que o mesmo princípio é adotado em outros regulamentos da ANEEL.

Em relação aos custos de eventuais melhorias ou reforços no sistema de distribuição por conta da conexão de uma microgeração, essas despesas ficaram por conta da distribuidora, exceto para a geração compartilhada. No entanto, para uma minigeração haverá a participação financeira do consumidor.

\subsection{Normas técnicas da ABNT: aprimoramento em curso}

Em relação às normas para os sistemas fotovoltaicos, a Associação Brasileira de Normas Técnicas (ABNT) publicou em 2014 a NBR 16274, relativa à documentação e testes de desempenho. Além disso, a última edição da NBR 5410, que trata sobre as instalações elétricas de baixa tensão, está passando por um período de revisão com base nas alterações do texto da International Electrotechnical Commission (IEC) correspondente e nas contribuições de participantes da Comissão de Estudos (CE) da ABNT (PORTAL SETOR ELÉTRICO, $2015)^{33}$.

\footnotetext{
${ }^{32}$ Ofício Circular $n^{\circ}$ 0022/2014-SRD/SCG/ANEEL, de 18/12/2014: micro e minigeradores que solicitaram acesso até 31/12/2014.

${ }^{33}$ Edição 110 de março de 2015. Obtido em: http://www.osetoreletrico.com.br/web/a-empresa/1631-aplicacoesda-abnt-nbr-5410.html.
} 
A seguir são apresentados os principais pontos que estão relacionados com o tema desta dissertação. A Tabela 4.2 mostra um resumo destes pontos.

Tabela 4.2 - Resumo das alterações propostas nas revisões das Normas da ABNT

\begin{tabular}{|c|c|c|c|c|}
\hline Item & Norma & Texto atual/anterior & Proposta & $\begin{array}{c}\text { Situação e impacto no } \\
\text { tema }\end{array}$ \\
\hline 1 & $\begin{array}{l}\text { NBR 16274: } \\
\text { Sistemas } \\
\text { Fotovoltaicos } \\
\text { conectados à rede }\end{array}$ & $\begin{array}{c}\text { Norma de 2014: } \\
\text { condições para } \\
\text { documentação, ensaios, } \\
\text { inspeção e avaliação de } \\
\text { desempenho. }\end{array}$ & & $\begin{array}{l}\text { Em vigor desde abril de } \\
2014 . \\
\text { Impacta nos custos de } \\
\text { projeto e } \\
\text { comissionamento. }\end{array}$ \\
\hline 2 & $\begin{array}{c}\text { Revisão da NBR } \\
\text { 5410: Instalações } \\
\text { elétricas de Baixa } \\
\text { Tensão }\end{array}$ & $\begin{array}{l}\text { Contexto não abrange o } \\
\text { sistema fotovoltaico. }\end{array}$ & $\begin{array}{l}\text { O sistema } \\
\text { fotovoltaico está } \\
\text { no contexto da } \\
\text { revisão. }\end{array}$ & $\begin{array}{l}\text { Em fase de Consulta } \\
\text { Pública. } \\
\text { Estabelece os requisitos } \\
\text { técnicos do projeto } \\
\text { elétrico do sistema } \\
\text { fotovoltaico. }\end{array}$ \\
\hline
\end{tabular}

Fonte: Próprio autor com base nas informações das revisões das Normas (2016).

\subsubsection{NBR 16274: Sistemas fotovoltaicos conectados à rede - Requisitos mínimos para documentação, ensaios de comissionamento, inspeção e avaliação de desempenho}

Essa Norma estabelece os requisitos mínimos para os procedimentos pós-instalação de um sistema fotovoltaico conectado à rede, abrangendo: a documentação, os ensaios de comissionamento e os critérios de inspeção. As atividades após o startup também estão englobadas tais como: inspeções periódicas e avaliação do desempenho do sistema.

A Norma é destinada especificamente às instalações de baixa tensão e voltada aos sistemas que não utilizem módulos de corrente alternada (CA), armazenamento de energia ou tecnologia híbrida.

Dentre outros aspectos, a Norma descreve diferentes regimes de ensaio adequados para diferentes tipos de sistemas fotovoltaicos, pois é recomendado que esses sejam adequados à escala, ao tipo e à complexidade, específicos de cada sistema.

\subsubsection{NBR 5410: Instalações elétricas de baixa tensão}

A NBR 5410, edição de 2004 na versão corrigida de 2008, tem por objetivo estabelecer as condições mínimas de projeto, execução e verificação de instalações elétricas de baixa tensão, 
a fim de garantir a segurança de pessoas e animais, o funcionamento adequado da instalação e a conservação dos bens. As instalações de baixa tensão são caracterizadas pela tensão nominal igual ou inferior a 1.000 Volts (V) em CA para frequência inferior a $400 \mathrm{Hertz}(\mathrm{Hz})$ ou 1.500 V em corrente contínua (CC). Sua aplicação é direcionada às instalações elétricas de edificações (inclusive sua área externa) sejam elas residenciais, comerciais ou industriais, incluindo as pré-fabricadas.

Em função da necessidade de atualização em sincronismo com a IEC e do avanço tecnológico do setor elétrico no País, dentre outros motivos, foi aberta a proposta de uma nova revisão da NBR 5410. Assim, a partir de março de 2012 foi desenvolvido o novo texto com base nas alterações da IEC correspondente e nas contribuições de participantes da Comissão de Estudos (CE) da ABNT. A nova edição foi aprovada na reunião plenária pela comissão e estará prosseguindo para a etapa de consulta pública ${ }^{34}$.

Acompanhando as tendências tecnológicas do setor, a nova redação insere em seu contexto a instalação fotovoltaica, estabelecendo dessa maneira uma diretriz técnica para seus circuitos elétricos de baixa tensão (MORENO, 2012) ${ }^{35}$.

\subsection{Literaturas técnicas: o fundamento}

Nesta seção são abordados os principais fundamentos envolvidos no tema deste trabalho.

O sistema fotovoltaico conectado à rede elétrica em geração distribuída pode ser visualizado em um diagrama esquemático conforme a Figura 4.1.

\footnotetext{
${ }^{34}$ Próximos passos serão: consulta pública, analise das contribuições, conclusão do texto, chancela da ABNT e publicação (ABNT).

${ }^{35}$ Engenheiro eletricista, consultor, professor e membro da comissão de estudos da ABNT NBR 5410 (O SETOR ELÉTRICO, 2015).
} 
Figura 4.1 - Diagrama de blocos de sistema fotovoltaico conectado à rede de baixa tensão

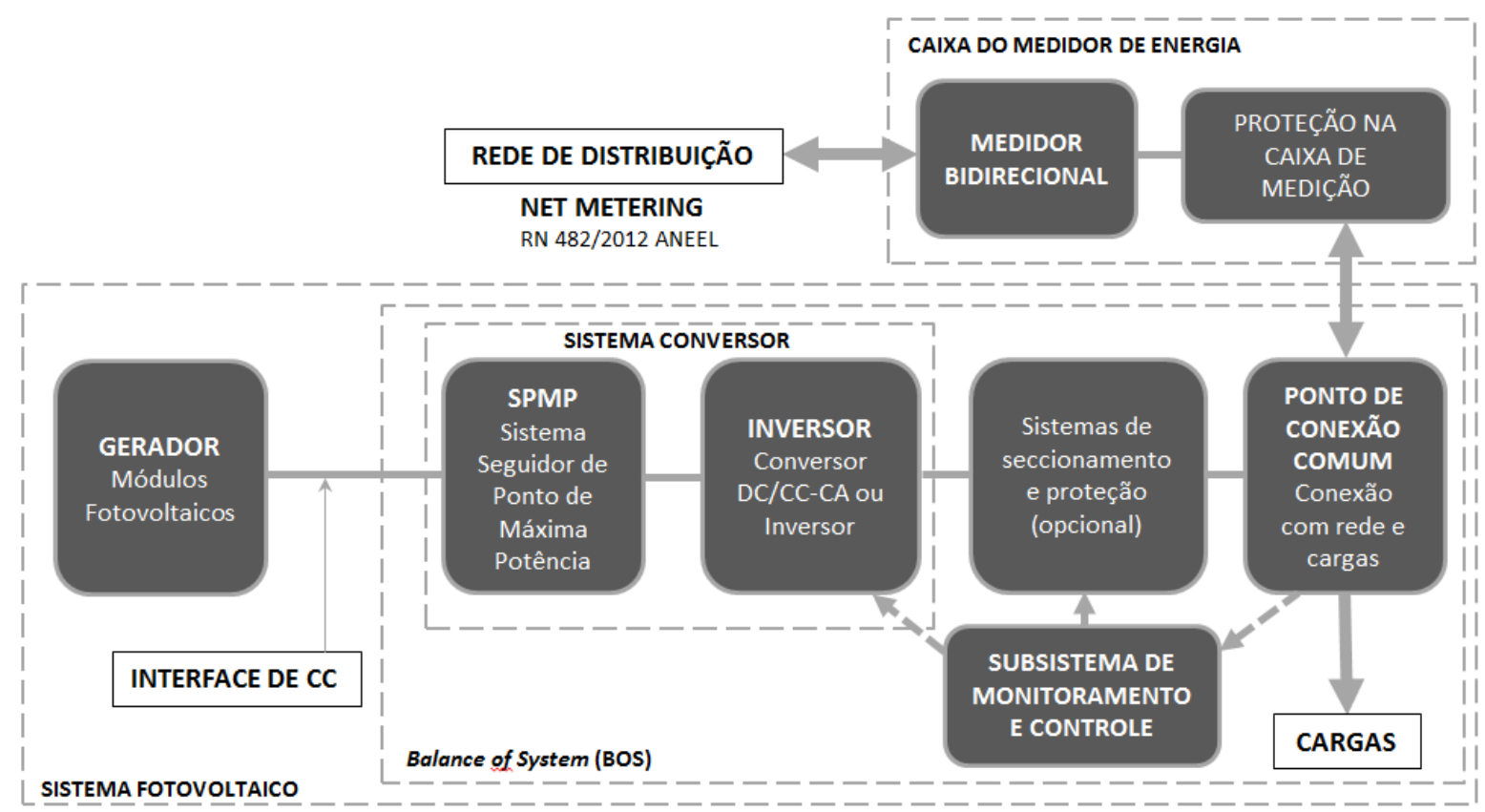

Fonte: Próprio autor com base na ABNT (2016).

O sistema fotovoltaico é formado basicamente por três partes principais: o gerador fotovoltaico, o conjunto de elementos que compõem o Balance of System (BOS) e o sistema de medição. O sistema conversor é composto pelos inversores que geralmente incorporam as funções do Seguidor do Ponto de Máxima Potência (SPMP) e as funções de monitoramento e controle.

\subsubsection{Conceito de Ponto de Máxima Potência - PMP}

O rastreamento do ponto de energia máximo ou seguidor de PMP (SPMP) é uma técnica que os inversores para conexão a rede (grid-tie) adotam para obter a potência máxima possível de um gerador fotovoltaico.

As células solares fotovoltaicas têm uma relação entre a irradiação solar, a temperatura e a resistência total (perdas), resultando em uma eficiência de saída não linear que pode ser analisada com base na curva de corrente-tensão (I-V), como mostrada na Figura 4.2. 
Figura 4.2 - Curva I-V de uma célula solar fotovoltaica típica

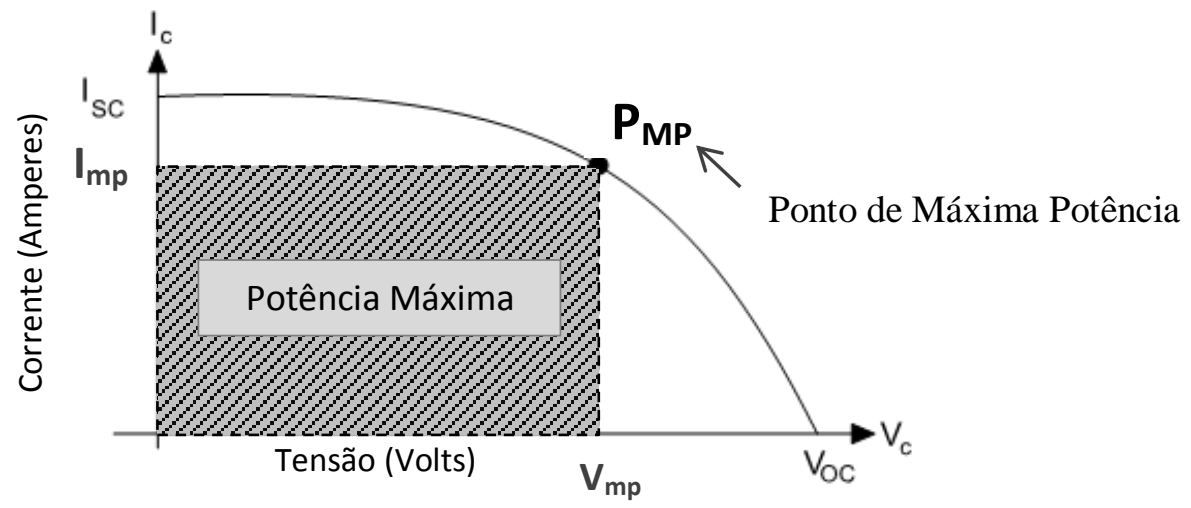

Fonte: Adaptado de Lopes; Garcia (2014)

Em que, Vmp e Imp são respectivamente os valores de tensão e de corrente que conduzem ao valor de potência máxima da célula. Para condição de curto-circuito, sendo $\mathrm{V}=0$, obtém-se o valor da corrente de curto-circuito (Icc ou Isc).

Para condição de circuito em aberto, sendo $I=0$, tem-se a tensão de circuito aberto (Voc). O rendimento é em função da potência máxima e da potência da luz incidente, conforme mostra a Equação (4.1).

$$
\eta=\frac{P_{\text {max }}}{P_{\text {luz incidente }}}=\left[V_{m p \times} I_{m p}\right] / P_{\text {luz incidente }}
$$

A curva típica I-V pode variar em função da intensidade de radiação solar incidente, da temperatura da célula e das perdas dinâmicas internas, como demonstrado na Figura 4.3.

Figura 4.3 - Variação da curva I-V em função da radiação e da temperatura

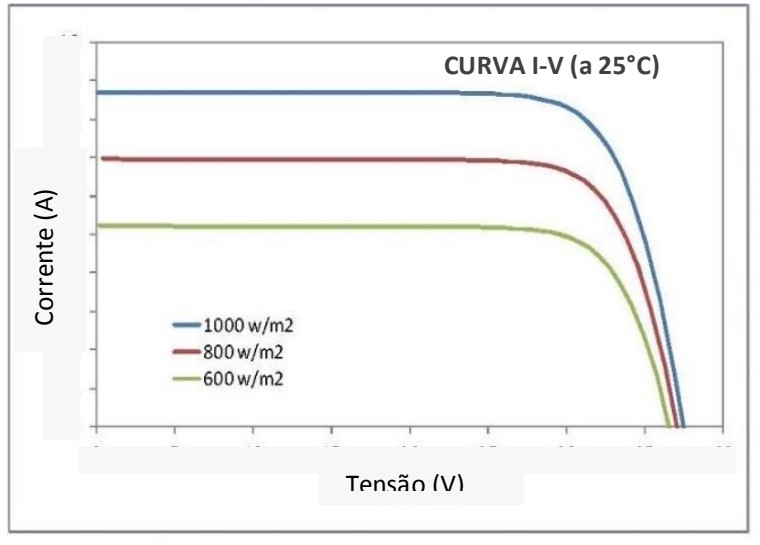

Variação I-V em função da radiação incidente.

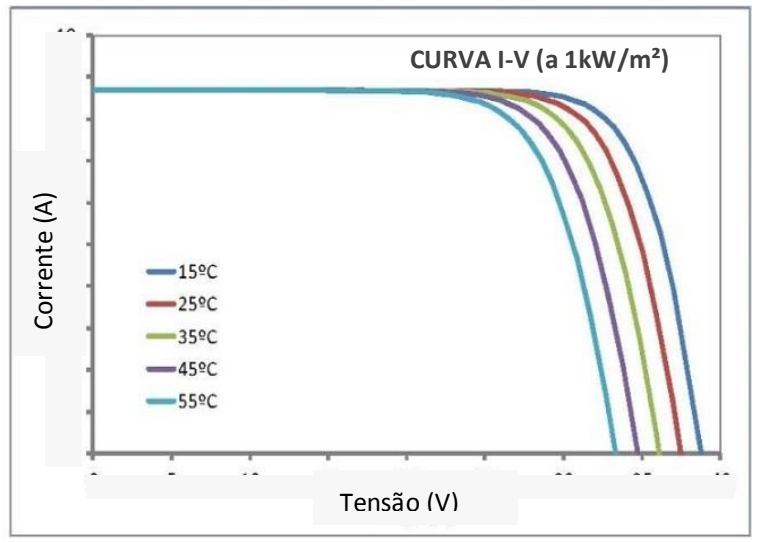

Variação I-V em função da temperatura da célula.

Fonte: Adaptado de Ingemecanica (2012). Tradução nossa. 
Pode-se observar a redução da radiação solar incidente causa uma queda da intensidade de corrente da célula, enquanto que a variação da temperatura influi inversamente em seu nível de tensão, conforme a Figura 4.4.

\section{Figura 4.4- Variação da potência gerada em função das perdas internas da célula}

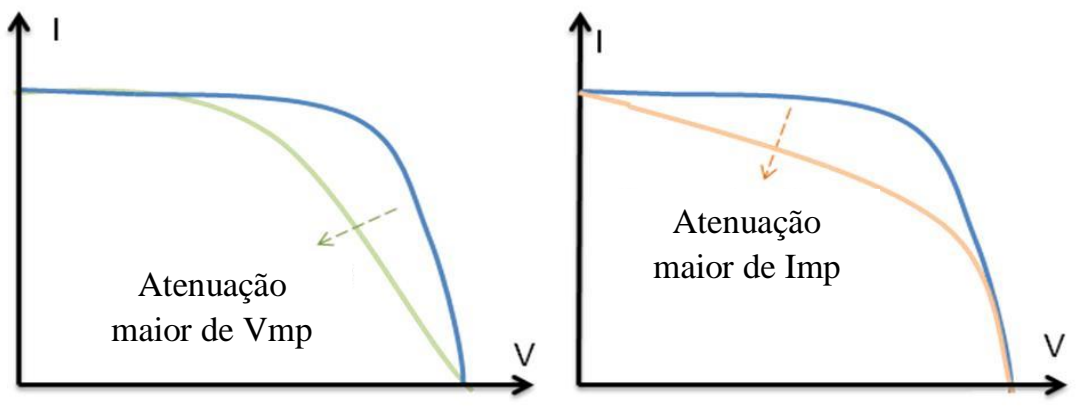

Fonte: Adaptado de National Instruments Corporation (2012). Tradução nossa.

As perdas dinâmicas internas das células deslocam seu ponto de máxima potência, resultando em menores eficiências. Esse deslocamento pode ocorrer com maior influência na atenuação da tensão de máxima potência (Vmp), como mostrado na figura à esquerda, ou na de corrente de máxima potência (Imp) mostrado na figura à direita.

O sistema de SPMP monitora a saída das células por meio de amostras de corrente e de tensão em períodos programados e aplica a resistência adequada para obter a potência máxima (PMP), localizada na região do joelho da curva I-V.

\subsubsection{Conceito de Fator de Forma - FF}

O fator de forma (FF) ou fill factor, é um parâmetro que caracteriza o comportamento elétrico não linear da célula fotovoltaica, e é definido como a razão entre a máxima potência gerada pela célula em condições reais (PMP) e a sua potência teórica em condições ideais (PT), dada pelo produto da tensão de circuito aberto (Voc) com a corrente de curto-circuito (Isc), conforme Equação (4.2).

$$
F F(\%)=\left[\frac{P M P}{V o c \times I s c}\right] \times 100
$$

Onde:

PMP: ponto de máxima potência em Watts;

Voc: tensão de circuito aberto do gerador fotovoltaico em Volts; 
Isc: corrente de curto-circuito do gerador fotovoltaico em Amperes.

O fator de forma representa o quão distante está o valor de máxima potência (PMP) em condições reais de funcionamento da célula em relação ao valor correspondente a máxima energia em condições ideais (PT), cuja situação está ilustrada na Figura 4.5.

Figura 4.5 - Fator de forma: relação entre a máxima potência real PMP e a potência teórica ideal PT

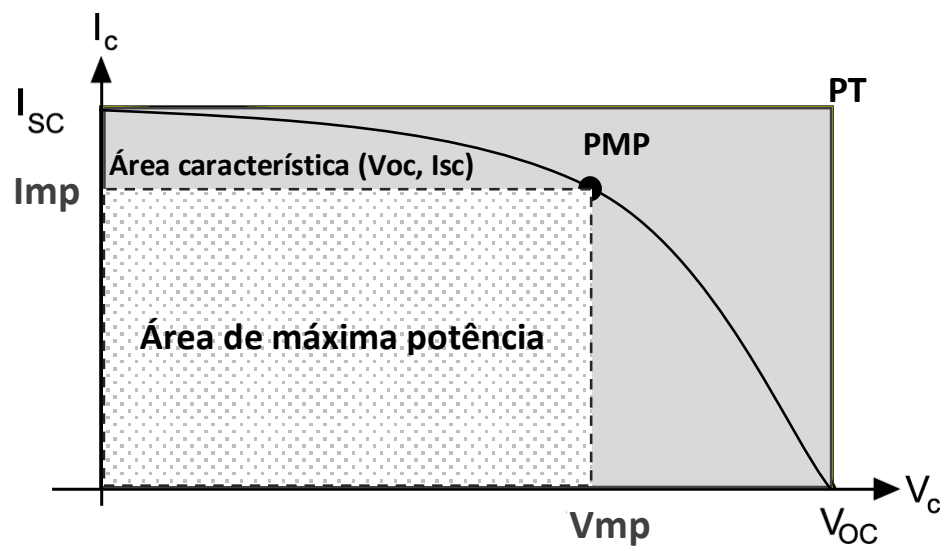

Fonte: Adaptado de Ingemecanica (2012).

Valores típicos de fatores de forma giram em torno de 0,50 a 0,82 , segundo a National Instruments $(2012)^{36}$.

\subsubsection{Determinação da potência fornecida pelo gerador fotovoltaico}

Inicialmente, é necessário analisar o perfil anual de potência entregue pelo gerador fotovoltaico dimensionado. Para tanto, devem ser considerados os parâmetros de radiação integrada diária média mensal sobre a superfície inclinada (HT) de ângulo de inclinação da superfície $(\beta)$ e a duração diária média mensal de insolação $(\mathrm{N})$, para se obter os valores correspondentes à irradiação média mensal sobre a superfície inclinada (Ht), expressa por:

$$
H_{t}=\frac{H T \times 1000}{N}
$$

Onde:

Ht: irradiação média mensal sobre superfície inclinada, em W/m²;

\footnotetext{
${ }^{36}$ Teoria das características I-V de células fotovoltaicas (National Instruments, Mai/2012).
} 
HT: radiação integrada diária média mensal sobre superfície inclinada, em $\mathrm{KWh} / \mathrm{m}^{2}$.dia;

$\mathrm{N}$ : duração da insolação média diária mensal, em h/dia.

Segundo o método baseado no modelo Polinomial de potência (ZILLES et al, 2012), a radiação solar incidente e a temperatura de operação das células têm influência na potência gerada pelo arranjo fotovoltaico.

Com base na irradiação média mensal sobre superfície inclinada (Ht), nos valores de temperatura ambiente média mensal da localidade (Ta) e nas informações do catálogo do fabricante do coletor, obtém-se o valor da temperatura média mensal da célula (Tc).

$$
T c=T a+\left\{H t \times\left[\frac{\left(T N O C-T a_{r e f T}\right)}{H_{r e f T}}\right] \times 0,9\right\}
$$

Onde:

Tc: temperatura média mensal da célula, em ${ }^{\circ} \mathrm{C}$;

Ta: temperatura ambiente média mensal do local, em ${ }^{\circ} \mathrm{C}$;

Ht: irradiação média mensal sobre superfície inclinada, em W/m²;

TNOC: temperatura nominal de operação da célula, especificada pelo fabricante, em ${ }^{\circ} \mathrm{C}$, nas condições de temperatura $\mathrm{Ta}_{\text {refT }}$, irradiância $\mathrm{H}_{\mathrm{refT}}$, velocidade do vento de $1 \mathrm{~m} / \mathrm{s}$ e montagem com parte de trás aberta;

$\mathrm{Ta}_{\text {refT }}$ : temperatura ambiente de referência nas condições de teste para $\mathrm{TNOC}^{37}$, que é de $20^{\circ} \mathrm{C}$;

$\mathrm{H}_{\mathrm{refT}}$ : irradiação de referência nas condições de teste para TNOC, que é de $800 \mathrm{~W} / \mathrm{m}^{2}$.

A partir deste resultado, podem ser calculadas as potências máximas geradas por um módulo fotovoltaico, em valores médios mensais, conforme a Equação (4.5).

$$
P m=P m p \times\left(\frac{H t}{H_{r e f S}}\right) \times\left\{1-\left[\gamma \times\left(T c-T c_{r e f S}\right)\right]\right\}
$$

Onde:

Pm: potência máxima gerada pelo coletor fotovoltaico, em W/modulo;

Pmp: potência máxima do coletor fotovoltaico, nas condições STC ${ }^{38}$, informada pelo fabricante;

Ht: irradiação média mensal sobre superfície inclinada, em W/m²;

$\mathrm{H}_{\text {refs: }}$ : irradiação de referência nas condições STC, que é de $1.000 \mathrm{~W} / \mathrm{m}^{2}$;

$\gamma$ : coeficiente de temperatura na potência Pm, especificado pelo fabricante;

\footnotetext{
${ }^{37}$ Nominal Operating Cell Temperature, é definida como a temperatura atingida pela célula em um módulo com irradiância na superfície da célula de $800 \mathrm{~W} / \mathrm{m}^{2}$, temperatura do ar em $20^{\circ} \mathrm{C}$ e velocidade do vento de $1 \mathrm{~m} / \mathrm{s}$.

${ }^{38}$ STC é uma referencia de condições de teste padrão, laboratorial, a $1.000 \mathrm{~W}$ por metro quadrado de "luz do sol", a temperatura da célula em $25^{\circ} \mathrm{C}$.
} 
Tc: temperatura média mensal da célula, em ${ }^{\circ} \mathrm{C}$;

$\mathrm{Tc}_{\text {refs: }}$ : temperatura de referência da célula nas condições STC, que é de $25^{\circ} \mathrm{C}$.

Os valores médios mensais de potência máxima que pode ser gerada pelo arranjo fotovoltaico são resultantes da seguinte equação.

$$
\boldsymbol{P m}_{\text {gerada FV }}=\frac{P m \times Q t_{\text {modulos }}}{1000}
$$

Onde:

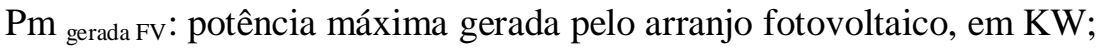

Pm: potência máxima gerada pelo coletor fotovoltaico, em W/modulo;

$\mathrm{Qt}_{\text {modulos: }}$ quantidade de módulos fotovoltaicos.

Dessa forma, podem-se dimensionar os valores médios mensais de potência máxima CC a serem entregues ao inversor e de potência máxima a ser gerada no sistema fotovoltaico, conforme as equações abaixo.

$$
\begin{aligned}
& P m_{\text {entregue ao inv }}=P m_{\text {gerada } F V}-\text { Perdas }_{\text {interface } C C} \\
& \text { Pm }_{\text {gerada sist }}=P m_{\text {entregue a } \text { inv }}-\text { Perdas }_{\text {inv }}
\end{aligned}
$$

Em que:

Pm gerada Fv: potência máxima gerada pelo arranjo fotovoltaico, em KW;

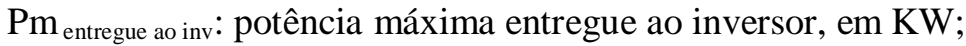

$\mathrm{Pm}$ gerada sist: potência máxima gerada pelo sistema fotovoltaico, em KW;

$\mathrm{P}_{\text {carga: }}$ potência máxima demandada pela carga, em KW.

É importante também realizar uma análise de coerência técnica entre os valores mensais de potência máxima gerada pelo sistema fotovoltaico e os de potência máxima demandada pelas cargas.

$$
P m_{\text {gerada sist }}>P_{\text {carga }} \Rightarrow \text { requisito mínimo para sistema isolados }
$$

$P m_{\text {gerada }}$ sist $\leq P_{\text {carga }} \Rightarrow$ permitido somente para geração distribuída ou para carga parcial

Sistema fotovoltaico que gera uma potência máxima maior que a potência demandada pela carga pode ser um caso aplicável em geradores isolados ou em geração distribuída, sendo que esse último implicará em uma parcela desnecessária de investimentos. Caso contrário, 
somente será permitida a aplicação do sistema em geração distribuída para atendimento à carga parcial.

\subsubsection{Determinação de energia produzida pelo gerador fotovoltaico}

Os valores máximos de energia diária média mensal entregues pelo gerador fotovoltaico são fornecidos através da equação abaixo.

$$
E_{\text {dia gerada FV }}=\left(\frac{P m \times N}{1000}\right) \times Q t_{\text {modulos }}
$$

Em que:

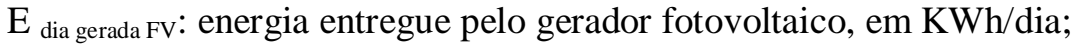

Pm: potência máxima gerada pelo coletor fotovoltaico, em W/modulo;

$\mathrm{N}$ : duração da insolação média diária mensal, em h/dia;

$\mathrm{Qt}_{\text {modulos: }}$ quantidade de módulos fotovoltaicos.

A energia gerada pelo sistema fotovoltaico, no ponto de entrega à carga, é dimensionada pela seguinte equação.

$$
E_{\text {dia gerada sist }}=E_{\text {dia gerada FV }}-\text { Perdas técnicas }
$$

Em que:

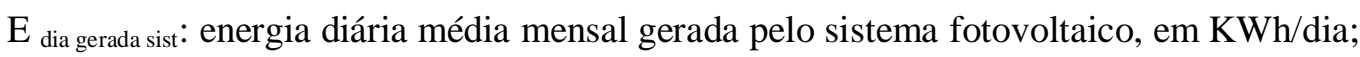

$\mathrm{E}_{\text {dia gerada } \mathrm{Fv}}$ : energia entregue pelo gerador fotovoltaico, em $\mathrm{KWh} / \mathrm{dia}$;

Perdas técnicas: perdas técnicas no sistema (instalação, inversor, CC, dispersão dos módulos, componentes).

Multiplicando-se os valores diários médios mensais de energia gerada pelas quantidades de dias em cada mês, pode-se visualizar o perfil de geração durante o ano.

$$
\boldsymbol{E}_{\text {mes gerada sist }}=\boldsymbol{E}_{\text {dia gerada sist }} \times \boldsymbol{n}_{\text {mes }}
$$

Em que:

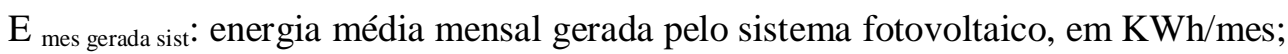

$\mathrm{n}_{\text {mes }}$ : quantidade de dias no mês. 
Assim, é possível realizar uma avaliação do balanço, mensal e anual, envolvendo a energia gerada e aquela que será consumida.

\subsubsection{Determinação do arranjo fotovoltaico}

As características do arranjo do gerador fotovoltaico (FV) devem estar em sintonia com as características do inversor, resultando na maximização da eficiência do sistema como um todo.

\subsubsection{Dimensionamento do inversor-conversor CC-CA}

\subsection{Conceito de inversores}

O inversor ou conversor CC-CA é um equipamento eletroeletrônico constituído de componentes semicondutores, sendo um dos principais elementos de uma instalação fotovoltaica e a sua principal função é converter o sinal elétrico de corrente contínua (CC) proveniente do gerador fotovoltaico em um sinal de corrente alternada (CA).

Os inversores constituem num ponto onde ocorre todo fluxo de potência, tendo a responsabilidade de dar maior eficiência ao sistema.

Nos sistemas fotovoltaicos conectados a rede (SFCR) o inversor é ligado diretamente à rede elétrica principal, injetando potência direta na rede.

A Figura 4.6 mostra um diagrama esquemático de um inversor de frequência típico.

Figura 4.6 - Diagrama esquemático de um inversor com monitoramento e controle

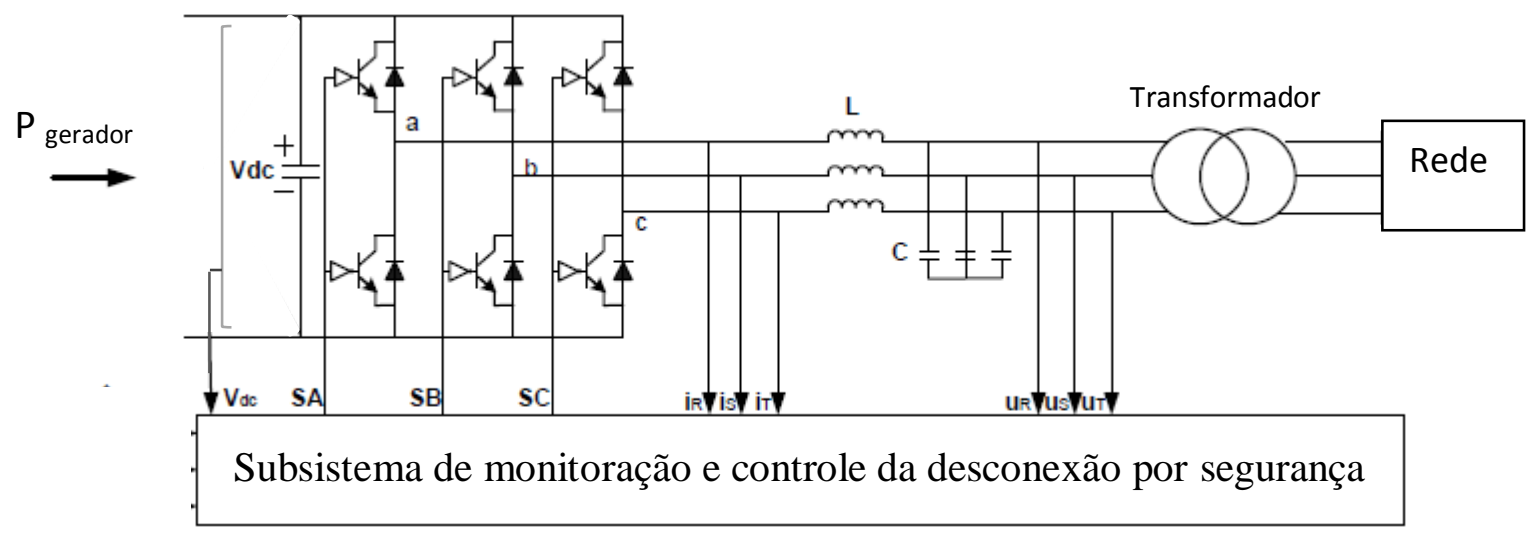

Fonte: Adaptado de Lopes (2013). 
Além da função de converter o sinal elétrico, o inversor assume outras atribuições como o ajuste do ponto operacional do inversor ao Ponto de Máxima Potência - Seguidor do Ponto de Máxima Potência (SPMP) do gerador fotovoltaico, a proteção na entrada e na saída de energia e a monitoração dos parâmetros elétricos com comando de atuação.

Os inversores devem proporcionar o maior fluxo de potência na conversão, devendo, portanto, estarem operando no ponto de máxima potência da geração (PMP). Para tanto, possuem um mecanismo de rastreio desse ponto que é o seguidor de PMP (SPMP), constituído de um conversor CC ligado em série com um dispositivo que ajusta a tensão de entrada do inversor à tensão correspondente ao PMP.

Os principais tipos de inversores existentes no mercado são baseados em três conceitos:

- Inversor central: os strings ${ }^{39}$ são conectados a um único inversor, o que restringe a aplicação em casos de incompatibilidade entre os módulos e de sombreamento parcial;

- Inversor de string: é uma versão reduzida do inversor central, sendo que cada conjunto de string é associado a um inversor e, portanto a um SPMP. Permite assim minimizar o impacto das influências de sombreamento parcial e de incompatibilidade entre módulos;

- Inversor multi-strings: semelhante ao inversor de string, porém com a diferença de possuir várias entradas de string (ou ao conjunto de strings), cada uma com seu SPMP independente. Essa solução permite usar, na mesma instalação, diferentes módulos fotovoltaicos com diferentes tecnologias e em diferentes orientações.

\subsection{Conceito do Fator de Dimensionamento do Inversor}

O fator de dimensionamento do inversor (FDI) é uma grandeza adimensional que relaciona a potência máxima do gerador fotovoltaico e a potência nominal do inversor, e é calculado conforme a seguinte equação.

$$
F D I=\frac{P n_{\text {inv }}}{P m p_{\text {gerador }}}
$$

Em que:

$\mathrm{Pn}_{\text {inv }}$ : potência nominal do inversor ou sistema conversor $(\mathrm{kW})$;

Pmp gerador: potência máxima do gerador fotovoltaico $(\mathrm{kWp})$.

\footnotetext{
${ }^{39}$ Conjunto de módulos fotovoltaicos interligados em série, de modo a formar a tensão de saída DC da unidade geradora. O termo string é de origem anglo-saxónica e significa "sequência ou série".
} 
A potência máxima do gerador fotovoltaico (Pmpgerador) pode ser obtida pela seguinte equação.

$$
P m p_{\text {gerador }}=P m p \times Q t_{\text {modulos }}
$$

Onde:

$\mathrm{Qt}_{\text {modulos: }}$ quantidade de módulos fotovoltaicos;

Pmp: potência máxima do módulo fotovoltaico $(\mathrm{kWp})$

É de fundamental importância a adoção de um FDI que permita ao SFCR utilizar ao máximo a energia gerada com uma maior eficiência.

O inversor deve ser adequadamente dimensionado para converter toda, ou ao menos a maior parte da potência, que é recebida do gerador, levando-se em conta as condições mais adversas de irradiação. Dessa forma, ele deve ser dimensionado de forma a se aproximar do ponto de equilíbrio entre duas vertentes técnicas:

- Se a potência nominal do inversor $\left(\mathrm{Pn}_{\text {inv }}\right)$ for inferior à potência máxima do gerador fotovoltaico $\left(\right.$ Pmp $\left._{\text {gerador }}\right)$, em picos mais elevados de potência o inversor poderá não conseguir processar toda a potência gerada pelo arranjo, resultando em perdas de potência e sobrecarga excessiva que afeta a sua vida útil. No entanto, na prática é muito improvável que os módulos do gerador atinjam seu pico de potência máxima nominal (condição STC) nas regiões com latitudes intermediárias;

- Se a potência do inversor for superior à potência do gerador, apesar de se obter um maior aproveitamento de potência, o inversor irá operar em baixo regime de carregamento diminuindo sua eficiência e como consequência reduzindo a potência total do sistema.

Portanto, o inversor deve estar numa faixa de dimensionamento que não leve o sistema a perder potência, ou seja, entre $20 \%$ a $90 \%$ da potência nominal do inversor que é a região para sua boa eficiência, e próximo da potência máxima do gerador dependendo da localidade. Especialistas definem uma faixa de potência do inversor de $75 \%$ a $120 \%$ da potência nominal do gerador fotovoltaico.

Em regiões de baixas latitudes, próximas à linha do Equador, os picos de radiação são mais frequentes e mais intensos, fazendo com que o gerador fotovoltaico opere mais próximo de sua potência nominal, exigindo assim uma maior potência de operação por parte dos 
inversores. Nesse caso o FDI deverá estar na faixa de $100 \%$ a $120 \%$. Em contrapartida, em locais com latitudes maiores o FDI poderá estar em faixas inferiores.

\subsection{Dimensionamento dos inversores}

Levando-se em conta as informações básicas de FDI, Pmp e $\mathrm{Qt}_{\text {módulos, }}$ pode-se dimensionar a potência nominal do sistema conversor, conforme equação:

$$
P n_{\text {inv }}=\text { Pmp }_{\text {gerador }} \times F D I
$$

Em que:

$\mathrm{Pn}_{\text {inv }}$ : potência nominal do inversor ou sistema conversor $(\mathrm{kW})$;

$\mathrm{Pmp}_{\text {gerador: }}$ potência máxima do gerador fotovoltaico $(\mathrm{kWp})$;

FDI: fator de dimensionamento do inversor.

\subsubsection{Dimensionamento do gerador fotovoltaico}

\subsection{Conceito de módulos fotovoltaicos}

O módulo fotovoltaico é a unidade onde ocorre o processo da conversão de energia através do efeito fotovoltaico e é constituído por diversas células solares agrupadas a fim de se obter uma potência nominal em níveis aplicáveis, como pode se observar na Figura 4.7.

\section{Figura 4.7 - Interligação de células fotovoltaicas}

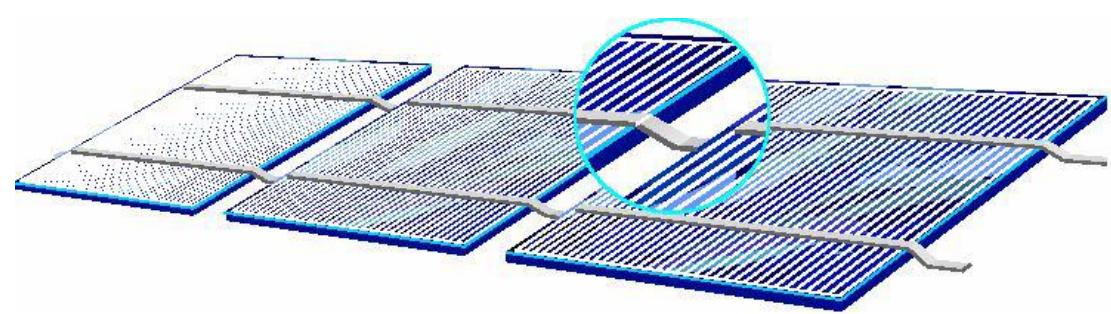

Fonte: Costa H. J. (2010).

Os módulos fotovoltaicos apresentam uma curva I-V, conforme Figura 4.8. 
Figura 4.8 - Curva característica de corrente-tensão do módulo solar

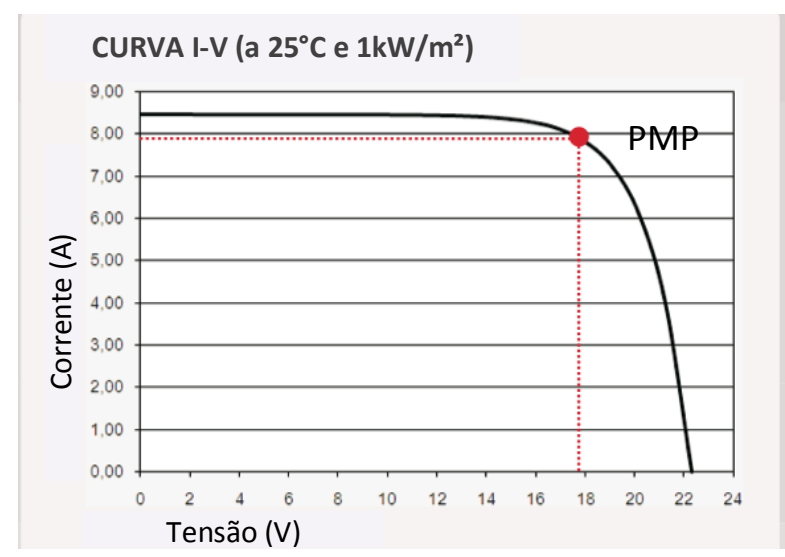

Fonte: Adaptado de Costa H. J. (2010).

Para cada ponto da curva o produto: tensão x corrente representa a potência gerada para aquela determinada condição de operação. Conforme mostrado na Figura 4.8, para um módulo fotovoltaico existe somente uma tensão e uma corrente das quais a potência máxima (PMP) pode ser extraída.

O ponto de potência máxima (PMP) corresponde, ao produto máximo [ tensão x corrente ]. A potência máxima de um módulo solar fotovoltaico, em Watts-pico (Wp), é referenciada às condições padrões de radiação, de temperatura da célula e de massa de ar, conforme STC/CPT: irradiação de $1.000 \mathrm{~W} / \mathrm{m} 2$, espectro de massa de ar AM de 1,5 e temperatura de célula de $25^{\circ} \mathrm{C}$.

Dois fatores relevantes influenciam o desempenho dos módulos fotovoltaicos: a irradiação e a temperatura da célula.

A influência da irradiação sobre o valor da corrente nos módulos tem um comportamento linear, conforme observado na Figura 4.9.

Figura 4.9 - Efeito causado na curva I-V do módulo em função do nível de radiação

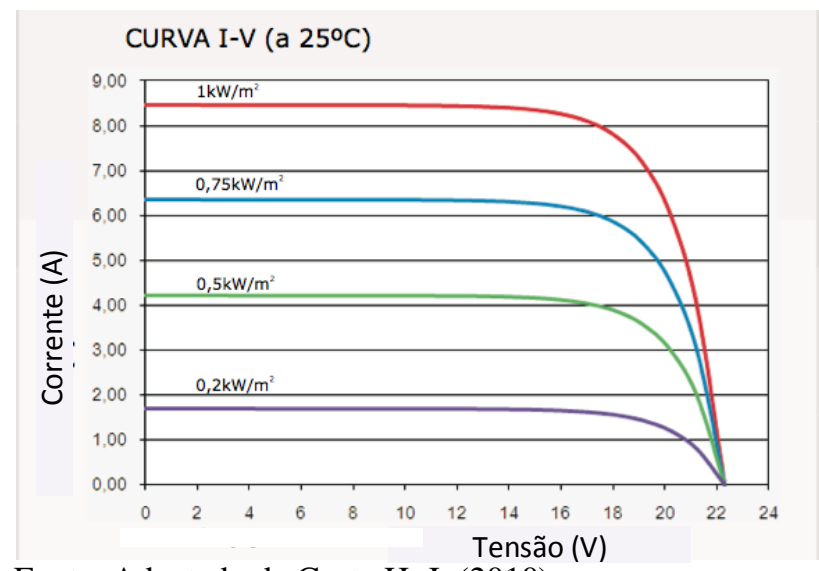

Fonte: Adaptado de Costa H. J. (2010). 
A temperatura das células, por sua vez, também altera as características elétricas dos módulos da seguinte forma: a incidência de um nível alto de insolação implica num aumento de temperatura das células dos módulos, e consequentemente numa menor potência de saída, conforme demonstrado na Figura 4.10 (COSTA H. J., 2010).

\section{Figura 4.10 - Efeito causado na curva I-V do módulo fotovoltaico pela variação da temperatura}

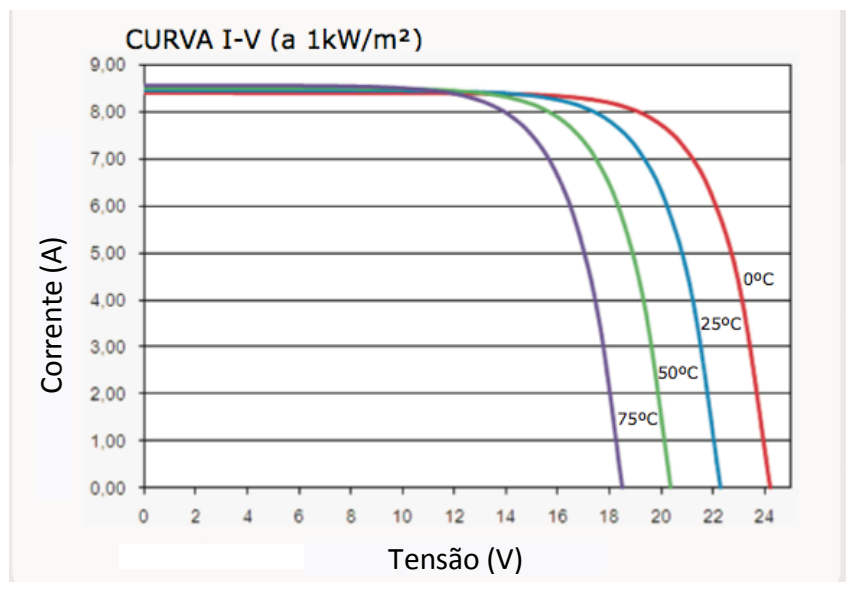

Fonte: Adaptado de Costa H. J. (2010).

Tanto o efeito causado pela variação do nível de radiação quanto a de temperatura, convergem para uma redução do nível de sua potência de saída, reduzindo, portanto, a sua eficiência.

\subsection{Ligações série e paralelo}

Os módulos são combinados entre si por meio de ligações em série (strings) ou em paralelo, a fim de maximizar a potência do sistema. No entanto, para evitar perdas de potência é recomendado o uso de módulos iguais nessas ligações.

No caso da conexão em série dos módulos fotovoltaicos, a corrente total do conjunto interligado será a mesma de um módulo individual e a tensão total do conjunto será a somatória das tensões individuais de cada módulo, permitindo, dessa forma, ajustar à tensão nominal da carga a ser alimentada.

Em locais ou momentos de elevados níveis de radiação, o procedimento de busca do ponto de máxima potência (PMP) executada pelo inversor, faz com que a tensão de saída do gerador fotovoltaico sofra uma redução em função das elevadas temperaturas das células dos módulos, comprometendo a eficiência do SFCR. 
Em casos críticos essa temperatura nos módulos pode ficar acima de $70^{\circ} \mathrm{C}$, assim costuma-se usar $70^{\circ} \mathrm{C}$ como base. Considerando esse aspecto, além de outros já citados neste estudo, o sistema deverá ser dimensionado de tal modo que o número mínimo de módulos ligados em série derive do quociente entre a tensão mínima de PMP do inversor ( $\left.\mathrm{V}_{\mathrm{PMP} \min }\right)$ e a tensão do módulo à temperatura de $70^{\circ} \mathrm{C}\left(\mathrm{V}_{\text {módulo }} 70^{\circ} \mathrm{C}\right)$, conforme equação (COSTA H. J., 2010).

$$
\text { Qts } S_{\text {min }}=\frac{V_{P M P \min }}{V_{\text {modulo } 70^{\circ} \mathrm{C}}}
$$

Em que:

Qts min: quantidade mínima de módulos ligados em série do string, nas condições especificadas;

$\mathrm{V}_{\mathrm{PMP} \text { min: }}$ tensão mínima aceitável pelo inversor para o PMP, do catálogo do fabricante, em Volts;

$\mathrm{V}_{\text {módulo } 70^{\circ} \mathrm{C}}$ : tensão simulada do módulo a temperatura da célula em $70^{\circ} \mathrm{C}$, em Volts.

A tensão mínima de PMP do inversor $\left(\mathrm{V}_{\mathrm{PMP} \text { min }}\right)$ é informada pelos fabricantes, porém a tensão do módulo à temperatura de $70^{\circ} \mathrm{C}\left(\mathrm{V}_{\text {módulo }} 70^{\circ}\right)$ deve ser dimensionada da seguinte forma.

$$
V_{\text {modulo } 70^{\circ} \mathrm{C}}=V m+\left\{\left[\left(70^{\circ} \mathrm{C}-\boldsymbol{T c}_{\text {refs }}\right) \times\left(\frac{\gamma}{100}\right)\right] \times V_{m}\right\}
$$

Em que:

Vm: tensão de máxima potência nas condições STC ${ }^{40}$, do catálogo do fabricante do inversor, em Volts;

$\mathrm{Tc}_{\text {refs: }}$ : temperatura de referência na célula nas condições STC, do catálogo do fabricante do módulo $\mathrm{FV}, \mathrm{em}{ }^{\circ} \mathrm{C}$;

$\gamma$ : coeficiente de temperatura nas condições STC, do catálogo do fabricante do módulo FV, em [\% / $\left.{ }^{\circ} \mathrm{C}\right]$.

Na forma de conexão em paralelo a tensão resultante do conjunto de módulos interligados tem o mesmo valor da tensão de um módulo individual, porém o nível de corrente total gerado pelo conjunto interligado é o resultado da somatória dos valores individuais de corrente dos módulos.

Na necessidade de se atingir níveis maiores de potência do SFCR, vastamente aplicados na prática, são feitas interligações mistas, série e paralela dos módulos, permitindo, assim, somar

\footnotetext{
${ }^{40} \mathrm{STC} / \mathrm{CPT}$ : irradiação de $1.000 \mathrm{~W} / \mathrm{m} 2$, espectro de massa de ar AM de 1,5 e temperatura de célula de $25^{\circ} \mathrm{C}$.
} 
as resultantes de máxima potência de cada módulo, gerando um fator multiplicativo na potência do sistema.

Uma vez definido o modelo do conversor CC/CA, é sempre importante avaliar qual a melhor configuração dos strings em função das características da(s) entrada(s) CC do inversor.

\subsection{Tecnologias fotovoltaicas: Estado da Arte}

As tecnologias fotovoltaicas usualmente são agrupadas em três categorias: as de $1^{\mathrm{a}}, 2^{\mathrm{a}}$ ou $3^{\mathrm{a}}$ geração, como mostrado na Figura 4.11.

Figura 4.11 - Agrupamentos das tecnologias de células fotovoltaicas

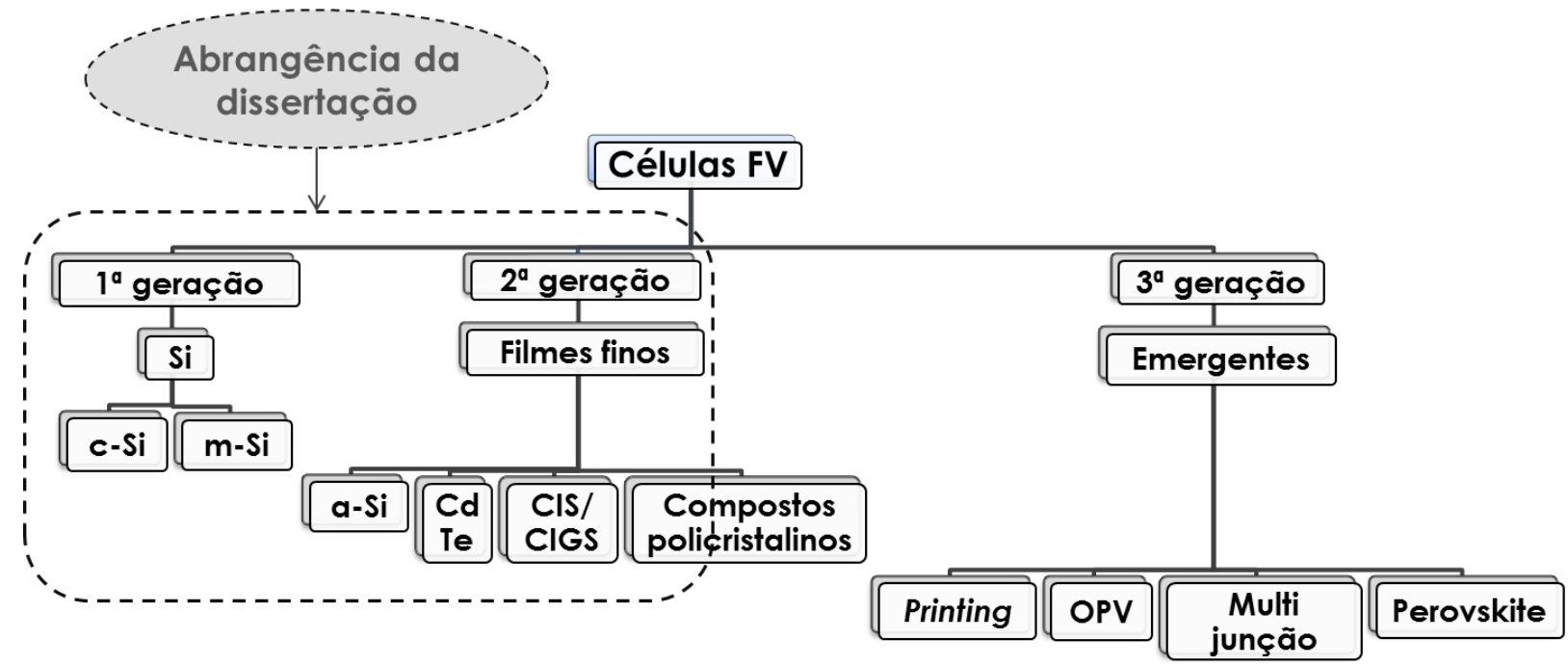

Fonte: Próprio autor (2016).

O grupo de $1^{\circ}$ geração é composto pelos módulos com painéis rígidos com células de silício cristalino. As células fotovoltaicas classificadas como de $2^{\mathrm{a}}$ geração são basicamente as tecnologias de filme fino. O terceiro agrupamento é formado pelas tecnologias mais recentes chamadas de emergentes.

Atualmente, o mercado internacional oferece, em volume relevante de escala industrial, três tipos de módulos fotovoltaicos: monocristalino, policristalino ou multicristalino e filme fino, os quais são abordados a seguir. 


\subsubsection{Silício cristalino}

O silício puro é um semicondutor intrínseco, apresentando uma separação (gap de energia) entre a banda de valência contendo quatro elétrons, e a banda de condução, totalmente vazia. Ao se aquecer o silício, os elétrons de valência se ligam aos seus átomos vizinhos, formando a rede cristalina.

A dopagem do silício com o boro gera um buraco de elétron na rede cristalina, e, portanto tendo um papel de receptor de elétrons, ou seja, um dopante do tipo p. Inversamente ao boro, a dopagem com o fósforo resultará em acréscimo de um elétron na rede cristalina, criando uma condição instável, necessitando de uma pequena energia para que o elétron seja transferido para a banda de condução. Dessa forma, o fósforo atua como um doador de elétrons ou dopante do tipo $n$.

A justaposição do material do tipo p com o do tipo n (junção p-n) produz um campo elétrico permanente na região da junção. A exposição da célula à luz causa uma excitação em alguns elétrons devido à absorção de fótons, acelerando os elétrons e gerando uma corrente através da junção. Essa corrente, por sua vez, faz surgir uma diferença de potencial entre as duas faces dessa junção, criando assim o efeito fotovoltaico.

\subsubsection{Painéis rígidos com células de silício cristalino}

São dois os tipos de células de silício cristalino que formam a chamada $1^{\text {a }}$ geração: monocristalino (c-Si) e policristalino ou multicristalino ( $\mathrm{m}-\mathrm{Si})$.

As células de silício monocristalino são fabricadas a partir de um único cristal com orientação definida e imerso em silício fundido (processo de Czochralski), produzindo, assim, lingotes com vários metros de comprimento (COSTA H. J., 2010).

O c-Si é o que apresenta as maiores eficiências entre as diversas tecnologias de junção única disponíveis no mercado.

Segundo Green et al $(2016)^{41}$, a maior eficiência desse tipo de célula ${ }^{42}$ é da Panasonic com $25,6 \%$, sendo que o módulo com maior eficiência ${ }^{43}$ no mercado é do mesmo fabricante, com

\footnotetext{
${ }^{41}$ Solar cell efficiency tables (Version 45). Prog. Photovolt: Res. Appl. 2015; 23:1-9. Sydney, Australia.

${ }^{42}$ Confirmed terrestrial cell and submodule efficiencies measured under the global AM1.5 spectrum (1000 W/m2) at $25^{\circ} \mathrm{C}$ (IEC 60904-3: 2008, ASTM G-173-03 global).

${ }^{43}$ Confirmed terrestrial module efficiencies measured under the global AM1.5 spectrum (1000 W/m2) at a cell temperature of $25^{\circ} \mathrm{C}$ (IEC 60904-3: 2008, ASTM G-173-03 global).
} 
23,8\%. Salvo módulos com características especiais, dispositivos baseados em células de silício monocristalino possuem eficiências na faixa de 13 a $18 \%$.

As células de silício policristalino, também denominado de multicristalino, são fabricadas mediante um processo de fundição do silício em estado bruto e depois esfriado, formando vários cristais. Os cristais de silício, então, são dopados, gerando uma junção p-n (COSTA H. J., 2010). Sua eficiência é tanto menor quanto menores forem os cristais que a formam.

A eficiência de módulos com células policristalinas normalmente está na faixa de $12 \%$ a 16\%, embora seja possível encontrar módulos dessa tecnologia com eficiências maiores. A máxima eficiência constatada recentemente dessas células está registrada em nome da empresa Trina Solar com 21,3\%, enquanto os módulos comercializados pela Hanwha Q-Cells oferece 19,5\% de eficiência (GREEN et al, 2016).

A estrutura de um painel fotovoltaico típico com células de silício cristalino é mostrada na Figura 4.12.

\section{Figura 4.12 - Estrutura do painel rígido fotovoltaico de silício cristalino}

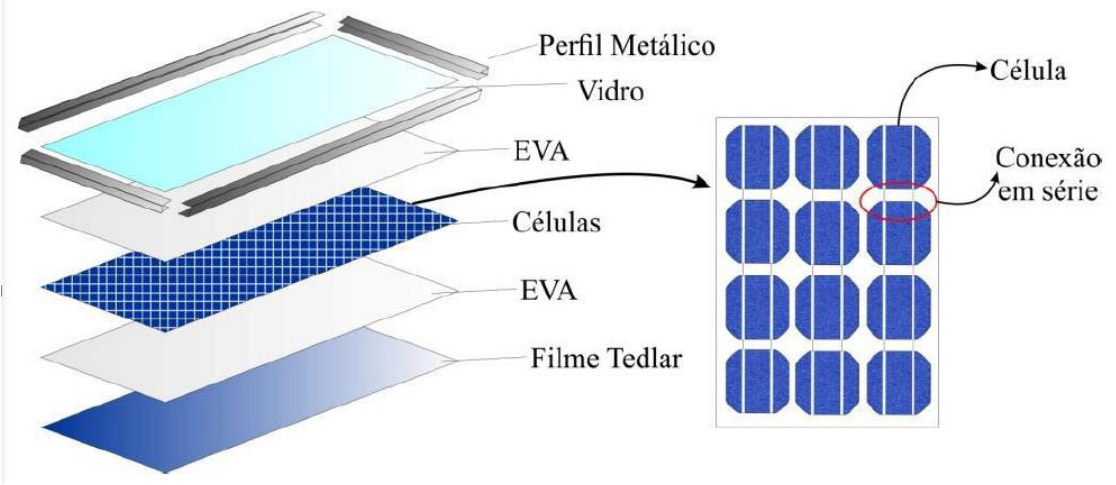

Fonte: Machado; Miranda (2014).

Os painéis comercializados, em sua maioria, são formados por módulos de células conectados em série por meio de filamentos condutores e encapsuladas em folhas de acetato de vinil etileno (EVA). A parte frontal do painel recebe uma cobertura de vidro temperado e a parte posterior uma proteção com filme de fluoreto de polivinila (PVF). O conjunto é enquadrado em um perfil metálico, geralmente em alumínio (MACHADO; MIRANDA, 2014). Seu ciclo de vida é estimado em 25 anos e a razão de ocupação de área está na faixa de 10 a $30 \mathrm{~m}^{2}$ por $\mathrm{kWp}$ instalado. 


\subsubsection{Filme fino}

Os módulos de filme fino são produzidos pelo processo de deposição de finas camadas, com espessuras da ordem de um milímetro, de semicondutores fotoativos em um substrato, como por exemplo, o vidro.

Os semicondutores adotados na maioria das aplicações, em junção única, são: o silício amorfo, o disseleneto de cobre e índio (CIS), o telureto de cádmio (CdTe) e o disseleneto de cobre, índio e gálio (CIGS).

\subsubsection{Silício amorfo (a-Si)}

As células de silício amorfo hidrogenado (a-Si:H) são fabricadas dispondo finas camadas de silício em um substrato.

As células de silício amorfo possuem uma estrutura com uma rede cristalina não uniforme apresentando muitas ligações pendentes e formação de buracos, que tendem a prejudicar o fluxo de corrente através delas. A hidrogenação do silício amorfo traz um benefício na eficiência da célula com a ocupação de parte dos buracos pelos hidrogênios.

Segundo Machado e Miranda (2014), a fabricação de filmes finos de silício amorfo hidrogenado faz uso do processo de deposição de silano $(\mathrm{SiH} 4)^{44}$ via descarga induzida por radiofrequência ou de deposição de vapor químico induzida por plasma. A mistura dessa atmosfera com $1 \%$ de hidreto de fósforo $(\mathrm{PH} 3)$ forma o material tipo $\mathrm{n}$, enquanto que a mesma porção de diborano (B2H6) na mistura resulta na dopagem do tipo p.

A célula de silício amorfo apresenta estrutura do tipo pi-n, conforme mostrado na Figura 4.13. A junção $\mathrm{p}-\mathrm{i}-\mathrm{n}^{45}$ tem por função gerar um campo elétrico ao longo da camada de a-Si intrínseco, criando um mecanismo de tração para aumentar o fluxo de elétrons.

\footnotetext{
${ }^{44} \mathrm{O}$ silano é um composto químico análogo ao metano $\left(\mathrm{CH}_{4}\right)$, porém derivado do silício, podendo ser empregado na deposição química de vapor de silício (wikipedia).

${ }^{45}$ Conceito criado por Carlson e Wronski em 1976 (Machado; Miranda, 2014).
} 


\section{Figura 4.13 - Estrutura da célula de silício amorfo}

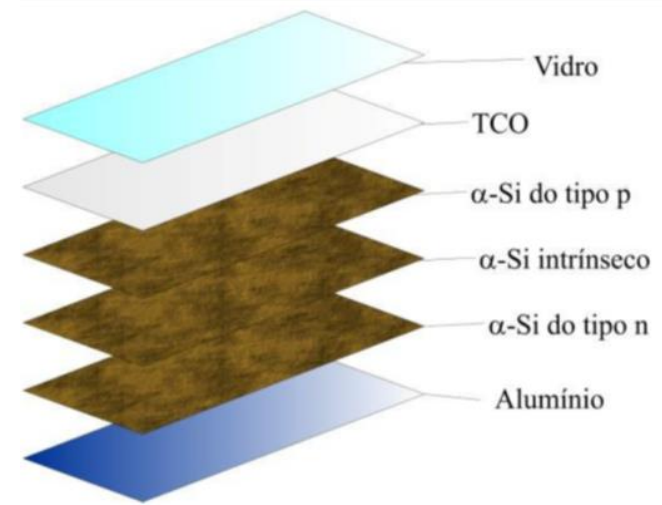

Fonte: Machado; Miranda (2014)

A parte central da estrutura é composta por três camadas sobrepostas de filmes de silício amorfo: filme dopado do tipo p, filme de silício intrínseco e filme dopado do tipo n. Na parte posterior é aplicada uma folha de alumínio cuja função é conduzir a corrente produzida e na parte frontal um óxido condutor transparente (TCO) que geralmente é o dióxido de estanho ( $\mathrm{SnO} 2)$. O conjunto é encerrado por uma proteção frontal por um vidro transparente.

Nessa tecnologia, os módulos são formados pelas próprias células pré-fabricadas, sem a necessidade de conexões entre elas.

A concepção de filme fino permite a aplicação dessa tecnologia em diversos tipos de materiais, como vidro, metais e plásticos, podendo ser flexíveis permitindo deformações. Outra vantagem do silício amorfo é obtida pela sua elevada absorção ótica na região da luz visível, com uma eficiência 40 vezes maior que o silício monocristalino, o que permite que uma lâmina de apenas $1 \mu \mathrm{m}$ seja capaz de absorver 90\% da energia solar útil (LASNIER; ANG, 1990). Além disso, essa tecnologia tem a sua resposta espectral mais voltada para a região do azul do espectro de frequência, levando a um aumento de eficiência sob a irradiação difusa.

Contudo, essa tecnologia apresenta nos primeiros meses de aplicação uma degradação induzida pela luz, chamada de efeito Staebler-Wronski (SW), causando uma redução em seu desempenho elétrico. Essa redução, normalmente especificada pelos fabricantes na ordem de $15 \%$, pode chegar a 35\% de acordo com Rüther et al (2003). Após o período de duração desse efeito, estimado na ordem de três a cinco meses, a eficiência estabiliza em valores próximos ao nominal informado nos catálogos dos fabricantes.

Esse fenômeno tem uma importância relevante no dimensionamento de um sistema fotovoltaico que aplique essa tecnologia, tanto na seleção de inversores quanto de outros 
elementos do sistema que tenham características inerentes à elevação de tensões causada pela eficiência das células nos primeiros meses.

Outro efeito denominado de thermal annealing, ou recozimento térmico, ocorre quando o módulo de silício amorfo é exposto a altas temperaturas causadas pela irradiação solar. Nesse caso, parte do efeito Staebler-Wronski é revertida, aumentando a eficiência dos módulos. Esse fato sugere a aplicação desse tipo de tecnologia em regiões de climas quentes (MAKRIDES et al, 2012), podendo sofrer um aumento de eficiência em até $20 \%$ nos meses mais quentes do ano.

Uma vantagem do silício amorfo em relação ao silício cristalino é a taxa de redução da potência em função do aumento da temperatura da célula, que ocorre em menores níveis.

Segundo Green et al (2016), a eficiência máxima registrada dessas células está em 10,2\% produzida pela empresa AIST, sendo que os valores normalmente praticados no mercado estão na faixa de 6 a $9 \%$.

\subsubsection{Células com junções múltiplas}

As junções múltiplas têm por função aumentar a eficiência da célula, com base na absorção de uma porção maior do espectro solar. As diferenças das sensibilidades espectrais entre os tipos de materiais podem ser exploradas sobrepondo-os em camadas, formando assim várias junções p-n dispostas de tal forma a absorver uma amplitude maior do espectro de frequência. Contudo, essas células são mais dispendiosas e por isso sendo direcionadas, geralmente, para os casos em que a limitação área é o fator mais importante, como por exemplo, nas aplicações espaciais.

As células de dupla junção podem ter como base o silício, como o a-Si/nc-Si e o a-Si/m-Si, ou outros materiais como o CdTe/CdS. Segundo Green et al (2016), a eficiência das células aSi/nc-Si variam na faixa de 12,3\% (TEL Solar em tandem) a 12,7\% (AIST).

Nas células de junção tripla, uma maior porção do espectro solar pode ser absorvida adotando uma composição adequada de materiais, de forma a absorver a luz azul na parte superior da célula, a luz verde na intermediária e a luz vermelha na inferior. A maior eficiência dessa tecnologia até o momento está registrada em 37,9\% obtida de um dispositivo com multijunção de InGaP/GaAs/InGaAs, produzido pela Sharp (GREEN et al, 2016). 


\subsubsection{Telureto de cádmio (Cd-Te)}

A célula de CdTe é composta de filmes sobrepostos formando uma heterojunção denominada janela/absorvedor. O alto gap da camada janela permite a transmissão da luz solar para dentro da camada absorvente, e assim, ocorrendo o efeito fotovoltaico.

Um desenho esquemático da célula de telureto de cádmio é mostrado na Figura 4.14.

\section{Figura 4.14 - Desenho esquemático de uma célula típica de CdTe}

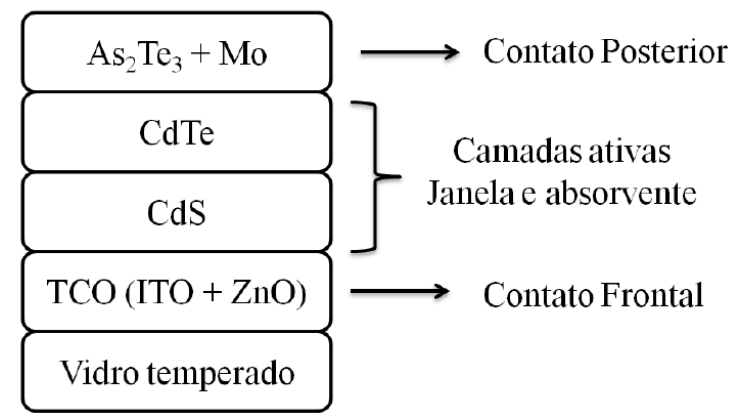

Fonte: Machado; Miranda (2014).

O contato frontal é feito a partir de uma camada de óxido condutor transparente (TCO) depositado sobre um vidro temperado. A camada seguinte é o sulfeto de cádmio (CdS), um semicondutor do tipo $\mathrm{n}$ opticamente transparente, que faz o papel da camada janela. Em contato com o CdS está a camada absorvente, o CdTe, um semicondutor do tipo p, formando a junção p-n. Para o contato posterior normalmente é adotado um metal.

Estas células podem possuir eficiências próximas as das tecnologias de silício policristalino, em função de seu alto grau de absortividade ótica. A diferença está no custo de materiais aplicados em cada tecnologia, sendo que para produzir a célula de CdTe é necessário o correspondente a $1 \%$ ou $2 \%$ do material requerido para a tecnologia mc-Si.

Os módulos formados com células de CdTe apresentam o efeito chamado de light soaking, ou imersão de luz, cuja característica é o aumento de sua eficiência após um tempo, que varia conforme o método de fabricação, de exposição à radiação solar.

Esse efeito tem uma influência relevante no dimensionamento do sistema fotovoltaico, pois a tensão de circuito aberto do módulo pode aumentar em até $6 \%$ após algumas centenas de horas de exposição à irradiação solar (DEL CUETO; VON ROEDEM, 2006). 
A eficiência máxima registrada até o momento para a célula está sob o domínio do fabricante First Solar (sobre vidro) no valor de $21 \%$, enquanto que para o módulo (monolítico) é de 18,6\% do mesmo fabricante (GREEN et al, 2016).

\subsubsection{Disselenetos de cobre-índio (CIS) e de cobre-índio-gálio (CIGS)}

A estrutura dessas células são semelhantes ao da célula de CdTe, apresentando as camadas janela e absorvente, e é baseada em uma camada condutora de lâmina fina de cobre, índio e selênio (CIS) ou de cobre, índio, gálio, e selênio (CIGS).

De acordo com especialistas, o CIGS é a tecnologia solar que atualmente tem o maior potencial e oferece grandes vantagens sobre as outras tecnologias de filme fino e de células de silício cristalino.

Enquanto as células cristalinas atuais têm espessura por cerca de $200 \mu \mathrm{m}$, o absorvedor do CIGS tem menos do que $2 \mathrm{~mm}$ de espessura, reduzindo o custo de material de produção.

Assim como a célula de CdTe, os materiais CIS e CIGS apresentam o efeito de light soaking e, portanto, os cuidados no dimensionamento do sistema fotovoltaico com relação à tensão de circuito aberto também devem ser observados.

O coeficiente de absorção de uma célula CIGS de espessura na faixa de $1 \mu \mathrm{m}$ a $3 \mu \mathrm{m}$, permite absorver em torno de $90 \%$ dos fótons incidentes que contenham energia superior a $1 \mathrm{eV}$, o que justifica o grande interesse do mercado nessa tecnologia (RAMPINELLI; BÜHLER 2012).

A variação da eficiência do CIGS em função da temperatura é similar a dos módulos de silício cristalino. No entanto, apresenta um maior rendimento a temperaturas mais elevadas do módulo.

Segundo Green et al (2016), os valores máximos obtidos atualmente para as células e módulos CIGS são, respectivamente, 21,0\% (sobre vidro) e 18,7\% ambos da Solibro, além dos módulos da Solar Frontier com 17,5\% (Cd free) e da Miasole com 15,7\% (filme fino).

Tal qual o a-Si ou o CdTe esses materiais apresentam uma excelente aparência estética possibilitando a aplicações integradas às fachadas dos edifícios, e, portanto para instalações verticais. 


\subsubsection{Tecnologias de $3^{\text {a }}$ geração}

As células e os módulos de $3^{\text {a }}$ geração ou nanoPV, compreendem as tecnologias emergentes, ainda com poucas opções de fabricantes no mercado mundial, e mesmo assim geralmente comercializada de forma casada com projetos específicos.

Com o objetivo de oferecer soluções que possibilitem a associação de eficiência com baixo custo e flexibilidade de aplicação, uma gama de novas tecnologias vem surgindo, algumas delas somente testadas em laboratórios e outras poucas em início de comercialização.

Essas tecnologias são produzidas por processos com temperaturas mais baixas em relação aos da tecnologia de $2^{a}$ geração, que são baseados na deposição a vácuo em altas temperaturas, e, portanto reduzindo os custos de fabricação.

Nesse cenário, situam-se, dentre outras, as células orgânicas, as células sensibilizadas por corante ou dye-sensitized solar cell (DSSC) e as células baseadas em pontos quânticos ou quantum dots.

As células orgânicas são formadas pela junção de duas camadas principais, onde ocorre o efeito fotovoltaico: uma delas tem a função de doar elétrons, enquanto que a outra camada é receptora de elétrons. Os principais fabricantes dessa tecnologia são a Toshiba e a Mitsubishi Chemical, detentores das maiores eficiências de células do mercado com 11,2\% e 11,1\%, respectivamente (GREEN et al, 2016).

As células DSSC têm como base um corante capaz de transferir um elétron no estado excitado para um óxido semicondutor, iniciando assim o processo de geração de corrente elétrica. Existem várias frentes de pesquisa focadas nos corantes que leve a uma maior eficiência das células, sendo os complexos de rutênio estão entre os mais utilizados no momento (MACHADO; MIRANDA, 2014).

Tanto a tecnologia DSSC como a orgânica, possuem propriedades que possibilitam opções com diferentes graus de transparência, diversificação na coloração e facilidade de ajuste nas propriedades óticas e de transporte de carga (NOGUEIRA, 2013).

Os resultados iniciais de eficiência obtidos pelo fabricante Sharp foram 11,9\% para as células e $8,8 \%$ para os submódulos, enquanto que a do minimódulo da Fujikura atingiu 10\% (GREEN et al, 2016).

As células baseadas em pontos quânticos, conhecidas como quantum dots solar cells, são classificadas em três tipos, em função dos materiais que compõem a sua junção com os nanocristais: metal-semicondutor ou junção Schottky, células orgânicas e quantum dots sensitized solar cells. 
Essa tecnologia faz uso dos quantum dots, que são nanocristais semicondutores com tamanho reduzido o suficiente para apresentar propriedades quânticas e comportamentos óticoeletrônicos específicos. No entanto, essas células ainda apresentam eficiências muito baixas, em torno de $1 \%$ a $3 \%$.

\subsubsection{BIPV e BAPV}

O sistema fotovoltaico integrado à edificação ou Building Integrated Photovoltaic (BIPV) tem por conceito a substituição de elementos de construção, como telhados e fachadas, por dispositivos fotovoltaicos com a função adicional de gerar energia elétrica e com a finalidade de reduzir os custos de investimento em materiais e serviços em relação às soluções tradicionais.

A integração pode ser do tipo funcional quando o elemento tem a função de envelopamento do edifício, enquanto que a integração estética tem o conceito arquitetônico de aparência e reconhecimento visual.

Os $B I P V s$ devem ter características de tal forma a satisfazer a proteção contra degradação à chuva e aos efeitos ambientais por todo seu ciclo de vida, e serem instalados de tal maneira a permitir um fluxo de ar na parte posterior dos módulos a fim de reduzir as perdas de eficiência em função das temperaturas das células. Outros fatores como inclinação, posição geográfica e orientação devem ser considerados durante a integração dos sistemas BIPVs, além de variáveis inerentes aos invólucros dos edifícios: por exemplo, a umidade.

Segundo a University of Applied Sciences and Arts of Southern Switzerland e a Solar Energy Application Centre (SUPSI; SEAC, 2015) os BIPVs podem ser classificados em função das áreas de aplicação: telhados inclinados, telhados planos e curvos, fachadas e outros, conforme mostrado na Tabela 4.3. 
Tabela 4.3 - Classificação das aplicações de BIPVs

\begin{tabular}{cl}
\hline Grupos & \multicolumn{1}{c}{ Classificação } \\
\hline & Sistemas de montagem sobre telhado \\
& Telhado completo (opaco/transparente) \\
Telhados & Telhas ou ardósias \\
inclinados & Painéis metálicos \\
& Vidros Solares \\
& Laminados flexíveis \\
& Telhas solares \\
\hline \multirow{2}{*}{ Telhados } & Painéis metálicos \\
planos e & Membranas solares \\
curvos & Vidros solares \\
& Clarabóias e telhado semitransparente \\
\hline \multirow{2}{*}{ Fachadas } & Fachada (elementos ou vidro) \\
& Sistema de sombreamento \\
& Vistema solar passivo \\
& Janelas \\
& Sistemas de revestimento \\
\hline \multirow{2}{*}{ Outros } & Mobiliário e estruturas urbanas \\
& Projetos BIPV customizados \\
\hline
\end{tabular}

Fonte: Próprio autor (2016).

Os grupos de telhados, inclinados ou curvos, abrangem desde soluções completas até telhas com montagens individualizadas, opacas ou semitransparentes. No entanto, as alternativas atualmente comercializadas no mercado mundial são focadas, em sua maioria, em telhados do tipo ardósia, laminados ou planos, pelo fato dos principais fabricantes serem de origem Europeia ou Asiática. As soluções para fachadas incluem elementos de vidros e sistemas de sombreamento, enquanto que existem outras aplicações para estruturas urbanas, como as coberturas de estacionamento.

Os BAPVs ou Building Applied (ou Attached ou Adapted) Photovoltaic são considerados elementos adicionados ao envelopamento dos edifícios. A diferença básica entre o BIPV e o $B A P V$ é que, enquanto o primeiro já é previsto durante a fase de projeto arquitetônico, o segundo geralmente é adicionado durante ou após a construção.

Tanto o $B I P V$ quanto o $B A P V$ surgem para contribuir no atendimento aos requisitos de desempenho do setor de construção civil no que tange a sustentabilidade e eficiência energética, além de favorecer o balanço energético brasileiro dentro do contexto do consumo de energia elétrica. No entanto, sua aplicação deverá sempre atender aos requisitos normativos em relação à segurança e aos aspectos técnicos do setor. 
Segundo a SUPSI-SEAC (2015), existem mais de 200 tipos de produto para BIPV na Europa, sendo fabricados com base em tecnologias de células fotovoltaicas tradicionais. Na Figura 4.15 pode-se observar a distribuição destas tecnologias no universo de soluções já adotadas.

\section{Figura 4.15 - Participação das tecnologias fotovoltaicas nos BIPVs}
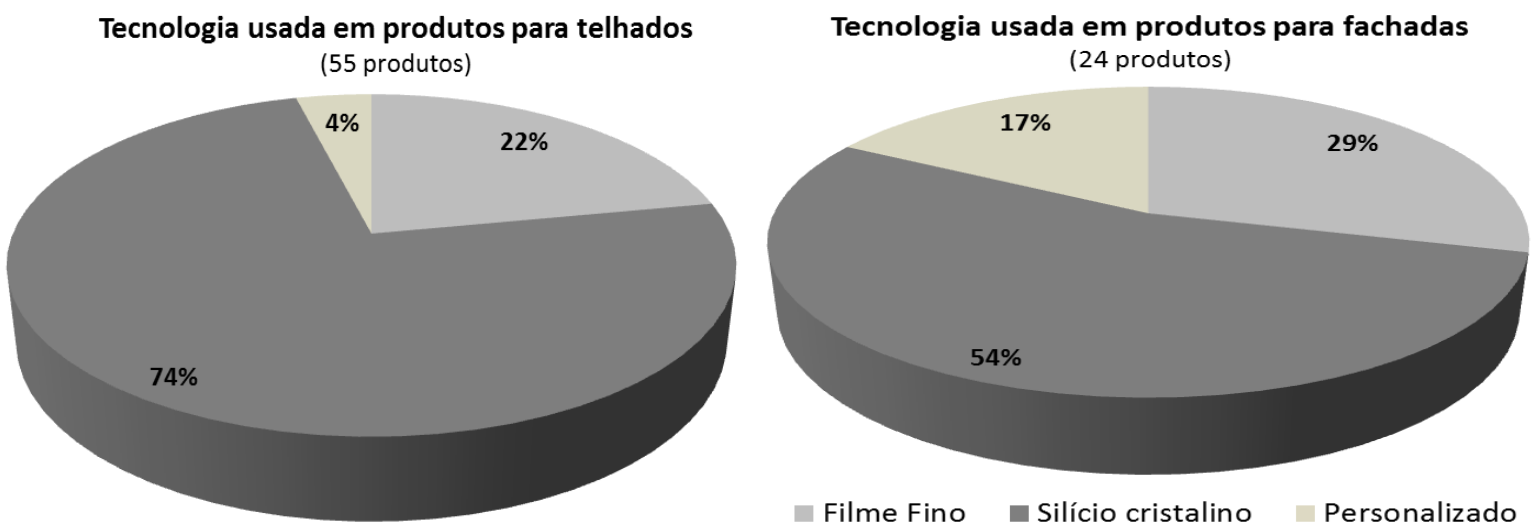

Fonte: Adaptado de SUPSI-SEAC (2015). Tradução nossa.

Nota-se na figura acima que a tecnologia de filme fino é utilizada em $22 \%$ dos produtos $B I P V$ para telhados, enquanto que sua participação nos produtos para fachadas é de $29 \%$. Esses percentuais são elevados comparando com a participação dos filmes finos na fabricação de módulos fotovoltaicos convencionais, devido ao seu menor custo e sua flexibilidade de aplicação. Por outro lado, o silício cristalino é adotado em $74 \%$ dos produtos para telhados e $54 \%$ das soluções em fachadas.

\subsubsection{Vidro fotovoltaico}

A tecnologia de BIPV glazing, ou vidro fotovoltaico para integração a edificação, ainda não possui participação significativa no mercado mundial por serem mais recentes e por estarem ainda em busca de melhores resultados em eficiência. Os modelos ofertados no mercado adotam as tecnologias de células fotovoltaicas convencionais ou, em poucos casos, as tecnologias de $3^{\mathrm{a}}$ geração.

Nos modelos que utilizam o silício cristalino, normalmente as células são depositadas entre dois vidros e distribuídas de forma a resultar em uma semitransparência e permitindo uma dosagem para cada tipo de aplicação. 
Outros fabricantes oferecem soluções com tecnologias CIS/CIGS e de silício amorfo, com grau de transparência em diversos níveis. Disponibilizado em forma laminada ou com vidros duplos, o semicondutor é aplicado em camadas muito finas ( $<1 \mathrm{~mm}$ ) no vidro.

As principais características dos vidros fotovoltaicos com tecnologia CIGS são: rendimento adicional de energia devido ao efeito de imersão luz e coeficiente de baixa temperatura que proporciona maior rendimento.

\subsection{Ferramenta computacional: Software de simulação solar}

O elevado valor inicial no investimento de um sistema fotovoltaico além da variabilidade do recurso solar e a grande gama de especificações de tecnologias de células fotovoltaicas comercializadas no mundo são alguns dos fatores que levam à necessidade de uma adequada ferramenta computacional para auxílio no desenvolvimento de projetos com resultados mais atrativos, fruto de simulações que permitam uma análise técnica e econômica com maior precisão e agilidade.

As ferramentas disponíveis no mercado mundial, gratuitas ou pagas, devem ser selecionadas em função das características específicas do projeto. Demandando uma maior ou menor interação com o usuário, nenhuma delas dispensa a necessidade de dados de entrada confiáveis e o mínimo de conhecimento técnico da tecnologia fotovoltaica por parte do projetista, principalmente para a interpretação dos resultados.

Há diversos softwares para simulação solar no mundo, tais como: o Hybrid Optimization Model for Electric Renewable (HOMER) desenvolvido e lançado em 2000 pelo National Renewable Laboratory (NREL) nos EUA e que requer uma interação maior com o usuário, o Integrated Simulation Enviroment Language (INSEL) da Universidade de Oldenburg na Alemanha, um dos mais antigos com ênfase nas áreas de aquecimento e resfriamento solar, o PV-DESIGNPRO da Maui Solar Energy Software Corporation disponibilizado a altos preços, o PVSYST da Universidade de Genebra que engloba todas as etapas de um projeto seja conectado à rede ou em sistema isolado, e o SOLARPRO originado em Kyoto, Japão, um dos mais completos do setor, mas com custos mais elevados. Há opções de ferramentas gratuitas como: o HYBRID2 criado em 1996 pela Universidade de Massachusetts em parceria com o NREL, mais voltado para sistemas isolados híbridos, o RETSCREEN do Minister of Natural Resources do Canadá, aplicado em projetos de energias renováveis em planilha MS-Excel, e o brasileiro PVSIZE desenvolvido pela Universidade Federal do Rio Grande do Sul e aplicado a sistemas isolados (CEPEL-CRESESB, 2014). 
Para auxílio no desenvolvimento desta dissertação foi selecionado o software PVSYST em função de suas características técnicas compatíveis com o método proposto e melhor custobenefício em relação aos demais.

Desenvolvido pela Universidade de Genebra na Suíça, o PVSYST é comercializado pela empresa PVSYST S/A. Capaz de tratar os projetos desde o seu estágio preliminar até a simulação em níveis mais complexos, incluindo visualização em um plano tridimensional que possibilita o estudo de sombreamento mútuo ou de objetos em seu entorno.

Dispondo de uma base de dados de irradiação de 222 localidades espalhadas pelo mundo, permite importar outros dados dos programas Meteonorm ${ }^{46}$ para comparação de valores simulados e medidos. Voltado preferencialmente para simulação de sistemas fotovoltaicos conectados à rede, possui um banco de dados com as especificações técnicas dos principais fabricantes mundiais de módulos e inversores.

Como resultado final o PVSYST fornece uma série de parâmetros técnicos do sistema simulado, incluindo suas perdas e seu grau de desempenho, além de permitir uma projeção de custos de produção de energia elétrica.

\subsubsection{As principais funções do software PVSYST}

O Software dispõe de quatro funções principais, sendo:

A primeira função é o estudo preliminar ou Preliminary design que permite uma rápida avaliação das potencialidades e possíveis restrições de um projeto fotovoltaico sob determinadas condições, contudo sua precisão é limitada.

A função de desenvolvimento do projeto ou Project design, parte principal do software, é uma ferramenta para o estudo completo de um projeto fotovoltaico, envolvendo: escolha de dados meteorológicos, desenho do sistema, estudo de sombreamento, determinação das perdas do sistema e apoio à análise econômica. Permite a simulação em regime horário por um período de um ano e fornece relatórios das simulações e dos resultados.

Com a finalidade de fornecer subsídios às funções anteriores, a base de dados ou Databases (terceira função) é formada por um banco de dados contendo registros climáticos horários e mensais, valores horários sintetizados e possibilita a importação de dados provenientes de outras bases externas.

\footnotetext{
${ }^{46}$ Meteonorm é um banco de dados de irradiação, temperatura e outros parâmetros meteorológicos, em formato compatível aos softwares de simulação térmica ou fotovoltaica. Base: 8.325 estações meteorológicas, cinco satélites geoestacionários e histórico de 30 anos.
} 
A última função que é a de ferramentas do software ou Tools auxilia na estimativa e na visualização do comportamento de um sistema fotovoltaico. Além disso, permite importar resultados de desempenho de instalações existentes para compará-los com a simulação.

Os dados meteorológicos utilizados como entrada consiste nas seguintes grandezas: irradiação global no plano horizontal, temperatura ambiente média, irradiação difusa no plano horizontal e opcionalmente a velocidade do vento. As duas primeiras grandezas são obtidas em base de dados externa, com o Meteonorm, e são selecionadas com a interação do usuário. As outras duas grandezas também podem ser encontradas da mesma forma, no entanto, na sua falta o software pode estimá-los com base em modelos matemáticos pré-estabelecidos.

A fonte de dados meteorológicos built-in do PVSYST é o programa Meteonorm, definido como padrão caso nenhum outro seja especificado. Alternativamente, é possível escolher dados, em diferentes formatos, via satélite a partir do sistema NASA-SSE ou via fontes públicas disponíveis na internet como SolarGIS, Satellight e Photon, ou ainda via empresas de meteorologia.

Antes mesmo da simulação é possível gerar relatórios relativos aos dados de entrada, em valores mensais, diários ou horários. Como as informações meteorológicas das bases de dados geralmente estão disponibilizadas em valores mensais, o PVSYST utiliza algoritmos específicos para gerar os valores horários.

A simulação pode ser realizada para cada uma das configurações definidas para o sistema fotovoltaico, havendo uma interação com o usuário para avaliações dos resultados e ajustes necessários. Ao final, o usuário poderá comparar todos os resultados.

Realizando simulações sucessivas, o usuário pode ajustar as variáveis básicas e inserir outras progressivamente, obtendo assim resultados adicionais como: sombreamento da linha do horizonte, sombreamento do entorno e do arranjo, perdas específicas etc.

A subseção de definições adicionais envolve o sombreamento do entorno (proximidades) e perfil do horizonte. O perfil do horizonte é aplicável para os objetos de sombreamento localizados à distância relevante do gerador fotovoltaico, ou seja, a uma distância maior que 10 vezes o tamanho do arranjo de módulos.

O tratamento de sombreamento do entorno ou dos objetos na proximidade, requer uma representação completa do sistema fotovoltaico em três dimensões (3D), que pode ser realizada por meio de um editor de $3 \mathrm{D}$ do software em plataforma com modelagem por objeto. 


\subsection{Base de dados}

\subsubsection{Dados solarimétricos}

A base de registros solarimétricos pode ser obtida de programas com acesso livre, sendo que os principais são:

- SunData: programa do Centro de Referência para Energia Solar e Eólica (CRESESB) que fornece a irradiação solar global diária média mensal, dentro do território brasileiro, em Quilowatt-hora por metro quadrado dia $\left(\mathrm{kWh} / \mathrm{m}^{2} \mathrm{dia}\right)$, relativa à localidade mais próxima da latitude informada e em quatro condições de inclinação do módulo: no plano horizontal, ângulo de inclinação igual à latitude, ângulo que resulta na maior média anual e ângulo que resulta no maior mínimo mensal;

- Atlas solarimétrico do Brasil - Banco de dados terrestres: coordenado por Chiguero Tiba et al (2000), que mostra os mapas de isolinhas de radiação solar global diária em plano horizontal, média mensal e média anual, em Mega Joules por metro quadrado dia $\left(\mathrm{MJ} / \mathrm{m}^{2}\right.$ dia $)$ e mapas de isolinhas de insolação diária, média mensal e média anual, em horas por dia (h/dia);

- Meteonorm: software que se comunica com a ferramenta computacional PVSYST, fornecendo uma gama de parâmetros de radiação solar como: radiação direta normal e sobre plano horizontal, radiação difusa extraterrestre, do nascer do Sol e sob céu claro, radiação global sobre plano horizontal, do nascer do Sol e sob céu claro, radiação integrada diária $(\mathrm{H})$, altura solar, albedo e duração do dia.

\subsubsection{Dados climáticos}

A variação de temperatura influi diretamente na eficiência dos módulos, e, portanto esses dados devem ser introduzidos no método proposto baseados, na maioria dos casos, nas médias máximas ou mínimas históricas. Os dados climáticos podem ser obtidos por meio de sites dos municípios, que possuem convênio com as estações meteorológicas mais próximas, ou através do Banco de Dados Meteorológicos para Ensino e Pesquisa (BDMEP) do Instituto Nacional de Meteorologia (INMET), ou ainda por meio de outros sites confiáveis. As variáveis atmosféricas disponibilizadas no banco de dados do INMET são: precipitação, temperaturas 
de bulbo úmido e seco, temperaturas máxima e mínima, umidade relativa do ar, pressão atmosférica ao nível da estação, insolação, direção e velocidade do vento.

É possível ainda obter os dados, no âmbito mundial, no programa Meteonorm que pode fornecer os seguintes parâmetros: níveis pluviométricos, temperatura ambiente média, mínima e máxima mensal, temperatura de orvalho e de bulbo seco, velocidade e direção do vento, pressão atmosférica, umidade relativa e dias com precipitação. 


\section{METODOLOGIA}

\subsection{Modelo conceitual simplificado do método aplicado}

Objetivando dar uma visão básica do método adotado neste trabalho foi elaborado um desenho esquemático conceitual com abordagem qualitativa, sendo dividido em seções contendo suas principais funções e suas relações.

Alinhado ao objetivo do trabalho, o modelo conceitual teve como foco as questões analíticas dos resultados técnicos relativos à geração de energia elétrica, para se comparar as diferentes tecnologias de célula fotovoltaica dispostas na fachada de um edifício. Assim, o método proposto contou com o apoio de um software (neste caso o PVSYST) como ferramenta auxiliar para os cálculos e dimensionamentos a fim de facilitar o processo de simulação. Uma visão macro do modelo conceitual é mostrada na Figura 5.1. 
Figura 5.1 - Modelo conceitual do método aplicado (visão macro)

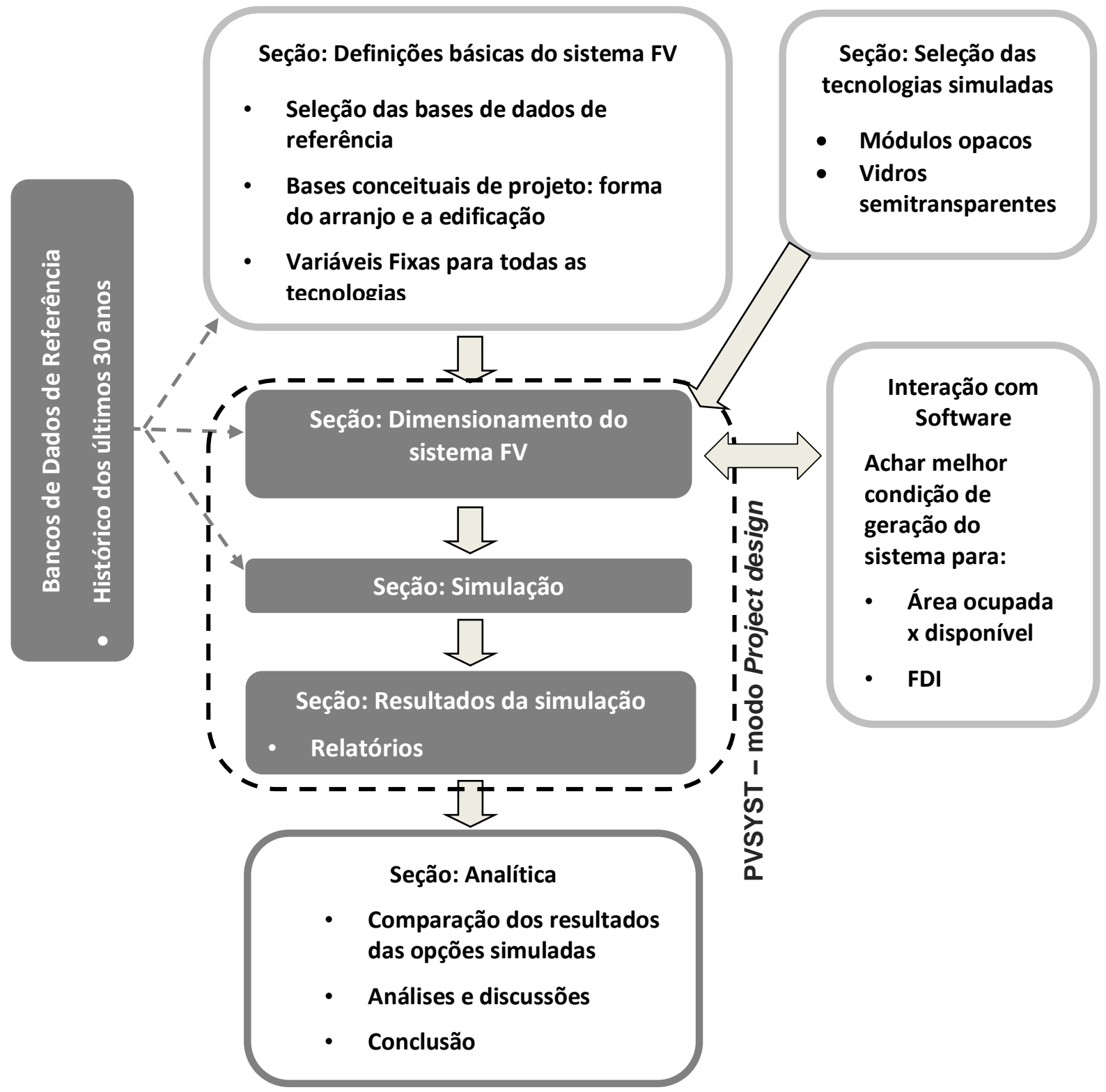

Fonte: Próprio autor (2016).

Pode-se observar que o modelo possui duas seções de entrada de dados (dados iniciais): uma denominada "Definições básicas do sistema FV" para inserção no software dos dados básicos para a simulação, pela da escolha de dados já cadastrados no "Banco de Dados de Referência" selecionado. Essa seção é formada por um conjunto, de variáveis fixas, aplicado em todas as simulações exercitadas, com a finalidade de equalizar os critérios para uma comparação entre os resultados das simulações com a minimização de influências específicas de cada tecnologia, como por exemplo: informações do local (país, cidade), orientação e inclinação dos módulos fotovoltaicos, entre outras. Pelo mesmo motivo, adotou-se uma edificação-tipo 
com área em sua fachada disponibilizada para o gerador fotovoltaico, conforme especificações estabelecidas nas "Bases conceituais de projeto". O conjunto de variáveis específicas, inerentes a cada tipo de tecnologia fotovoltaica, foi formado com base nos dados disponibilizados no "Banco de Dados de Referência", tais como dimensões dos módulos e área ocupada pelas células fotovoltaicas.

Outra seção do método aplicado foi a "Seleção das tecnologias simuladas", em que foram definidas as tecnologias de células fotovoltaicas selecionadas para as simulações, representadas pelos fabricantes e seus modelos. Essa seleção foi orientada por pesquisas e comparações entre as tecnologias, à luz de um critério com cinco variáveis: relevância na participação do mercado mundial, grau de eficiência nominal de conversão de energia, condição de cadastro no banco de dados do software PVSYST, situação perante o Instituto Nacional de Metrologia, Qualidade e Tecnologia (INMETRO) e situação relativa à comercialização. As tecnologias fotovoltaicas selecionadas foram agrupadas em: módulos opacos ou vidros semitransparentes.

A seção de "Bancos de Dados de Referência", contida no software PVSYST, reúne os endereços eletrônicos dos principais websites para obtenção do histórico de registros inerentes às bases para o dimensionamento técnico do sistema, tais como: base de dados de radiação solar ou climáticos por localidade e especificações de fabricantes de equipamentos.

A seção "Dimensionamento do sistema FV" estabeleceu os elementos e a configuração do sistema fotovoltaico, fornecendo, após "Simulação" no software PVSYST, os resultados como, por exemplo, a energia elétrica gerada, as perdas em função do sombreamento e as características do sistema fotovoltaico (seção "Resultados da simulação"). Houve uma "Interação com Software" pelo usuário no momento da definição inversor-arranjo fotovoltaico, a fim de buscar a melhor solução em desempenho do sistema.

$\mathrm{Na}$ seção "Analítica" do método aplicado, o resultado da simulação de cada tecnologia foi analisado e comparado com as demais, considerando seu comportamento em relação à geração de energia elétrica e suas perdas específicas.

A seguir são apresentados os passos e as definições relativos ao método aplicado no desenvolvimento deste trabalho.

\subsection{Seleção das tecnologias simuladas}

A escolha das tecnologias fotovoltaicas simuladas teve como critério básico cinco variáveis, conforme comentadas a seguir. 


\subsubsection{Banco de dados do PVSYST}

A primeira variável foi quanto à disponibilidade da tecnologia e do modelo do módulo fotovoltaico no banco de dados do PVSYST.

O módulo de banco de dados do PVSYST (Databases) contém, dentre outras informações, as especificações técnicas dos módulos fotovoltaicos existentes no mercado internacional, que podem ser carregadas de duas formas: inserindo todos os dados técnicos manualmente com base em catálogos de fabricantes ou importando-os da base de dados do site www.photon. Info ${ }^{47}$, já em formato compatível na versão free access.

O procedimento manual evidencia certa dificuldade no que tange a obtenção dos dados, pois a maioria dos fabricantes não disponibilizam em seus catálogos, e mesmo em consultas verbais, todas as informações técnicas necessárias de seus produtos para o completo preenchimento da tabela do banco de dados do PVSYST. Esse fato colocaria em risco a confiabilidade dos casos a serem simulados, sendo ainda mais relevante para as tecnologias mais recentes, as quais sofrem os efeitos de degradação inicial no desempenho do sistema e apresentam uma diversificação no aproveitamento da radiação solar difusa.

No entanto, a base de dados de acesso gratuito do photon database não está mais disponível desde março de $2016^{48}$, devido à reconfiguração de seu site $\left(\right.$ MERMOUD $^{49}, 2016$; PHOTON, 2016), implicando, a partir de então, na necessidade de carregamentos manuais para atualização do banco de dados do PVSYST.

Diante desse panorama, optou-se pela adoção dos dados disponibilizados no banco de dados do PVSYST, atualizado até março de 2016, pelas seguintes razões:

- Evitar riscos de perda de confiabilidade nos casos simulados em função da falta de informações nos catálogos dos fabricantes;

- Facilitar a etapa de simulações, pois o foco deste estudo é a discussão comparativa dos resultados obtidos de cada tecnologia fotovoltaica;

- Os principais fabricantes (e seus produtos) das tecnologias de primeira geração, caso dos módulos rígidos de silício cristalino, permanecem em posições relevantes no mercado mundial;

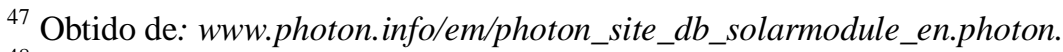

${ }^{48}$ Obtido de: http://forum.pvsyst.com/viewtopic.php?t=21\&p=21.

${ }^{49}$ André Mermoud, Ph.D em Física de partículas, autor do software PVSYST e fundador da PVSYST SA.
} 
- Em relação às tecnologias de segunda geração, caso do CIS e do CIGS, há fabricantes com histórico confiável no mercado internacional e que constam no banco de dados do PVSYST, não implicando em alterações significativas de desempenho durante o período de março de 2016 até hoje.

Dentre todos os modelos de módulos fotovoltaicos cadastrados no banco de dados do PVSYST, foram somente considerados aptos para a simulação aqueles disponíveis para comercialização pelos fabricantes. Essa condição (segunda variável) foi obtida também do banco de dados do PVSYST.

\subsubsection{Tabela do INMETRO}

A terceira variável do critério de escolha das tecnologias e dos modelos dos módulos simulados teve como base a condição de aprovação pelo órgão certificador brasileiro: o Instituto Nacional de Metrologia, Qualidade e Tecnologia (INMETRO) ${ }^{50}$.

O INMETRO, por meio de seu Programa Brasileiro de Etiquetagem (PBE), realiza ensaios laboratoriais no produto englobando atributos, como a eficiência energética, e emite a etiqueta classificando seu respectivo desempenho em função dos resultados obtidos frente aos requisitos das normas técnicas. Quando a principal informação é a eficiência energética do produto, caso deste estudo, o selo é chamado de Etiqueta Nacional de Conservação de Energia, e estabelece faixas coloridas que variam da classificação mais eficiente (A) a menos eficiente (E), como é mostrado na Tabela 5.1.

Tabela 5.1 - Critérios de classificação dos módulos fotovoltaicos segundo PBE

\begin{tabular}{|c|c|c|c|}
\hline \multirow{2}{*}{$\begin{array}{c}\text { EFICIÊNCIA } \\
\text { ENERGÉTICA }\end{array}$} & CLASSES & \multicolumn{2}{|c|}{ ÍNDICE DE MÓDULO } \\
\cline { 2 - 4 } & SILICIO CRISTALINO & FILMES FINO \\
\hline Mais eficiênte & $A$ & $E E>13,5$ & $E E>9,5$ \\
\hline & $B$ & $13,5>=>13,0$ & $9,5>>>7,5$ \\
\hline & $C$ & $13,0>=E E>12,0$ & $7,5>=E E>6,5$ \\
\hline & $D$ & $12,0>=E E ~>11,0$ & $6,5>=E E>5,5$ \\
\hline Menos eficiênte & E & $E E<11,0$ & $E E<5,5$ \\
\hline
\end{tabular}

Fonte: adaptado do INMETRO (2016)

\footnotetext{
${ }^{50}$ INMETRO é uma autarquia federal brasileira, no formato de uma agência executiva, vinculada ao Ministério do Desenvolvimento, Indústria e Comércio Exterior (MDIC).
} 
Pode-se observar na Tabela 5.1 que, no caso dos módulos fotovoltaicos, a classificação é baseada no índice de módulo que é categorizada por tecnologia: silício cristalino e filmes finos. Essa separação se deve ao fato da tecnologia de primeira geração, o silício cristalino, se encontrar em uma fase de desenvolvimento mais madura e suportado por um histórico de evolução bem solidificado. Por outro lado, as tecnologias de segunda geração, como os filmes finos, possuem uma eficiência menor em relação ao silício cristalino, porém ainda se encontra em fase de evolução. Isso sugere a necessidade futura de revisões dos parâmetros do índice de módulo.

O INMETRO divulga periodicamente, dentre outras, a Tabela de Eficiência Energética para Sistema de Energia Fotovoltaica, com o objetivo de informar os modelos etiquetados e sua respectiva condição dentro do programa.

Um resumo da totalização dos módulos fotovoltaicos etiquetados e divulgados na edição 01/2016 da tabela do INMETRO de 31 de maio de 2016, é mostrado na Tabela 5.2.

Tabela 5.2 - Eficiência Energética - Sistema de Energia Fotovoltaica - Módulos (Resumo)

\begin{tabular}{|c|c|c|c|c|c|c|}
\hline \multirow{2}{*}{ CLASSES } & \multicolumn{2}{|c|}{ ÍNDICE DE MÓDULO } & \multicolumn{2}{|c|}{ SILICIO CRISTALINO } & \multicolumn{2}{|c|}{ FILMES FINOS } \\
\hline & SILICIO CRISTALINO & FILMES FINO & TOTAL & $\%$ & TOTAL & $\%$ \\
\hline A & $E E>13,5$ & $\mathrm{EE}>9,5$ & 491 & 86,7 & 14 & 56 \\
\hline B & $13,5>=>13,0$ & $9,5>=>7,5$ & 23 & 4,1 & 3 & 12,0 \\
\hline c & $13,0>=E E>12,0$ & $7,5>=E E>6,5$ & 27 & 4,8 & 1 & 4 \\
\hline D & $12,0>=E E>11,0$ & $6,5>=E E>5,5$ & 8 & 1,4 & 3 & 12 \\
\hline E & $E E<11,0$ & $E E<5,5$ & 17 & 3,0 & 4 & 16,0 \\
\hline & & & 566 & 100 & 25 & 100 \\
\hline
\end{tabular}

Fonte: INMETRO (2016)

Observa-se que há módulos classificados com etiqueta $\mathrm{A}$ em percentuais relevantes no universo testado: $86,7 \%$ na categoria de silício cristalino e $56 \%$ na de filmes finos. Assim, para a seleção dos módulos simulados levou-se em conta, inicialmente, a condição de atendimento à classificação $\mathrm{A}$.

No entanto, para alguns casos pré-selecionados nesse quesito as condições exigidas pelas variáveis relacionadas com o banco de dados do PVSYST (cadastrados e comercializados) não foram atendidas. Nesses casos, optou-se por modelos de módulos com características mais próximas daqueles que constam na tabela do INMETRO, como por exemplo, a tecnologia de filme fino de CIS do fabricante alemão Avancis. 
Outros modelos de módulos também foram incluídos nas simulações pelo fato de serem citados em periódicos científicos, ou por opção tecnológica, mesmo não sendo contemplados na tabela do INMETRO, tais como os fabricantes com tecnologia de vidros fotovoltaicos (BIPV glazing): Vidursolar, Schott Solar e SolarWatt, além da TSMC com sua tecnologia CIGS.

\subsubsection{Periódicos e artigos}

A quarta variável do critério de escolha das tecnologias e dos modelos dos módulos simulados, com um peso menor, se baseou no grau de relevância de sua participação no mercado mundial, citado em artigos ou na tabela de eficiência de células solares do periódico Solar cell efficiency tables em sua edição 48 de maio de 2016 (GREEN et al, 2016).

A tecnologia de primeira geração com seus módulos rígidos de silício cristalino, dominante no mercado mundial, apresenta uma grande gama de fabricantes disseminados em vários países, sendo que boa parte desses possuem o selo brasileiro do INMETRO. Na escolha dos fabricantes e dos módulos simulados, foram selecionados aqueles que, além de atenderem aos requisitos do INMETRO (com as devidas exceções) e constarem no banco de dados do PVSYST, tinham participação relevante no mercado mundial.

A Figura 5.2 apresenta os dez maiores fabricantes mundiais de 2015 com base em seus embarques, segundo Mints ${ }^{51}$ (2016).

Figura 5.2 - Top Ten mundial de fabricantes de módulos fotovoltaicos (ano 2015)

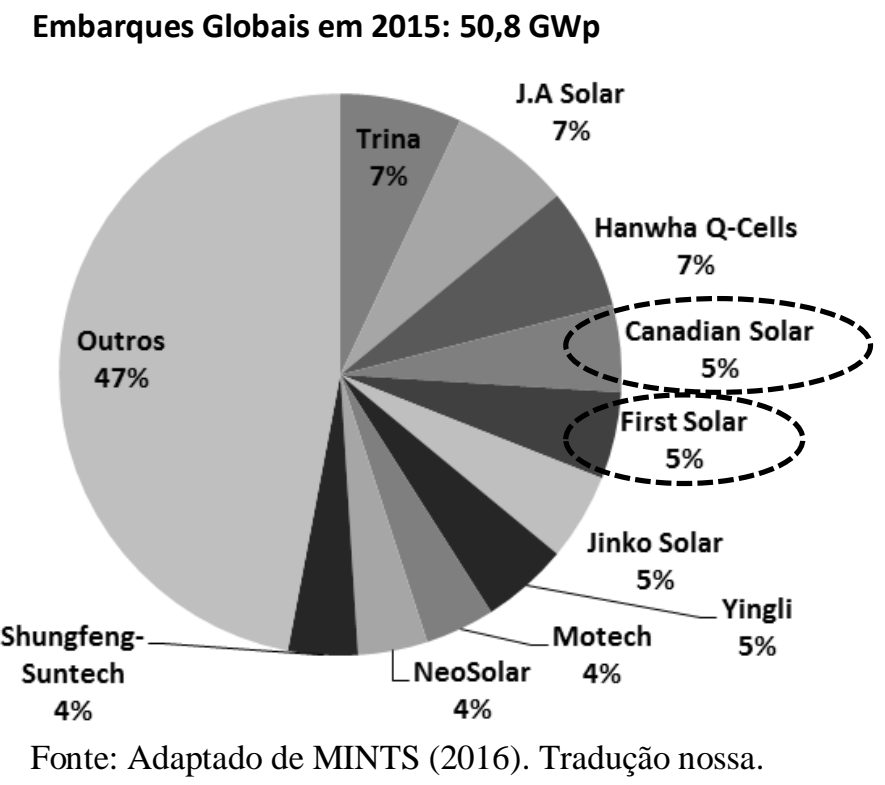

${ }^{51}$ Paula Mints: Fundadora e Analista de pesquisa de Mercado da SPV Market Research. 
Nota-se na Figura 5.2 que a Canadian Solar participa com 5\% da matriz de produção mundial aplicando a tecnologia de silício cristalino, e a First Solar com outros 5\% divididos entre a tecnologia de telureto de cadmio e de silício cristalino. Segundo Mints (2016), em 2015, os dez maiores fabricantes tiveram $46 \%$ de participação na matriz mundial de fabricação de módulos rígidos e $42 \%$ na de filmes finos e células fotovoltaicas.

Portanto, esses fabricantes foram selecionados para a simulação deste estudo, sendo a Canadian Solar com sua tecnologia de silício cristalino e a First Solar com a de telureto de cadmio.

Outra referência de desempenho, mas voltada para o aspecto de eficiência fotovoltaica (quinta variável do critério), foi o periódico Solar cell efficiency tables (GREEN et al, 2016) em sua edição de número 48 de maio de 2016, e divulgado pela Progress in Photovoltaics. Essa pesquisa apresentou e comparou os melhores resultados de eficiência até janeiro de 2016 para cada tecnologia fotovoltaica do mercado mundial, sendo agrupadas conforme sua forma de aplicação: como célula, em módulos ou em concentradores. Os resultados foram obtidos por meio de testes e ensaios efetuados em laboratórios independentes (não pelos próprios fabricantes) e com reputação reconhecida.

Para efeito deste trabalho foi adotada a Tabela II do periódico que mostra os resultados de eficiência na forma de módulo fotovoltaico, conforme apresentado na Tabela 5.3.

Tabela 5.3 - Eficiências de módulos terrestres confirmadas sob regime STC

\begin{tabular}{|c|c|c|c|c|c|c|c|}
\hline Classificação & $\begin{array}{c}\text { Eficiência } \\
(\%)\end{array}$ & $\begin{array}{l}\text { Área } \\
\left(\mathrm{cm}^{2}\right)\end{array}$ & $\begin{array}{l}\text { Voc } \\
(\mathrm{V}) \\
\end{array}$ & $\begin{array}{l}\text { Isc } \\
\text { (A) } \\
\end{array}$ & $\begin{array}{l}\mathrm{FF} \\
(\%) \\
\end{array}$ & $\begin{array}{c}\text { Local dos } \\
\text { ensaios }\end{array}$ & Descrição \\
\hline Silicio cristalino & $23,8 \pm 0,5$ & $11.562,0$ & 53,4 & 6,32 & 81,6 & AIST (1/16) & Panasonic (72 células) \\
\hline Silicio policristalino & $19,5 \pm 0,4$ & $15.349,0$ & 41,53 & 9,299 & 77,4 & FhG-ISE (12/15) & Hanwha Q Cells (120 cells) \\
\hline GaAs (Filme Fino) & $24,1 \pm 1,0$ & 858,5 & 10,89 & 2,255 & 84,2 & NREL (11/12) & Alta Devices \\
\hline CdTe (Filme Fino) & $18,6 \pm 0,6$ & $7.038,8$ & 110,6 & 1,533 & 74,2 & NREL $(4 / 15)$ & First Solar, monolítico \\
\hline CIGS (livre de cadmic & o) $17,5 \pm 0,5$ & 808,0 & 47,6 & 0,408 & 72,8 & AIST (6/14) & Solar Frontier (70 cells) \\
\hline CIGS (largo) & $15,7 \pm 0,5$ & $9.703,0$ & 28,24 & 7,254 & 72,5 & NREL (11/10) & Miasole \\
\hline a-Si/nc-Si (tandem) & $12,3 \pm 0,39$ & $14.322,0$ & 280,1 & 0,902 & 69,9 & ESTI $(9 / 14)$ & TEL Solar, Trubbach Labs \\
\hline Organico & $8,7 \pm 0,3$ & 802,0 & 17,47 & 0,569 & 70,4 & AIST (5/14) & Toshiba \\
\hline Multijunção & $312+12$ & 9680 & 2305 & 1506 & 036 & & Sharn (32 cells) \\
\hline InGaP/GaAs/InGas & J1,2I1,2 & 900,0 & 25,93 & 1,500 & 93,0 & AIS $1(2 / 10)$ & snarp ( 32 cells) \\
\hline
\end{tabular}

Fonte: Adaptado de GREEN et al (2016). Tradução nossa. 
A Tabela 5.3 mostra que o fabricante americano First Solar apresentou um resultado relevante $(18,6 \%)$ com sua tecnologia de filme fino em telureto de cadmio. Já para o CIGS o melhor resultado foi do fabricante alemão Solar Frontier (17,5\%). Esses dois fabricantes foram selecionados para a etapa de simulações, porém trazendo modelos de módulos que atendessem aos requisitos, já descritos anteriormente, do critério estabelecido.

\subsubsection{Definição das tecnologias simuladas}

Como resultado desta etapa de seleção, a Tabela 5.4 resume o universo das tecnologias abrangidas nesta simulação.

Tabela 5.4 - Matriz de seleção das tecnologias simuladas

\begin{tabular}{|c|c|c|c|c|c|c|c|c|c|}
\hline Tipo & Fabricante & Sede & Tecnologia & Modelo & $\begin{array}{c}\text { Relevancia } \\
\text { no mercado } \\
2015\end{array}$ & $\begin{array}{c}\text { Eficiência } \\
\text { relevante } \\
2016\end{array}$ & $\begin{array}{l}\text { BD do } \\
\text { PVSYST }\end{array}$ & $\begin{array}{l}\text { Tabela do } \\
\text { INMETR0 }\end{array}$ & $\begin{array}{c}\text { Comercializado } \\
\text { atualmente }\end{array}$ \\
\hline \multirow{6}{*}{$\begin{array}{c}\text { Vidro } \\
\text { fotovoltaico } \\
\text { semi } \\
\text { transparente }\end{array}$} & VIDURSOLAR & Espanha & Si-Poli & $\begin{array}{l}\text { FV VS36 C54 (36\% } \\
\text { transp) P180 (2009) }\end{array}$ & $\mathrm{X}$ & $\mathrm{X}$ & 0 & $\mathrm{X}$ & 0 \\
\hline & VIDURSOLAR & Espanha & Si-Poli & $\begin{array}{l}\text { FV VS16 C54 (16\% } \\
\text { transp) P120 (2009) }\end{array}$ & $\mathrm{X}$ & $\mathrm{X}$ & 0 & $\mathrm{X}$ & 0 \\
\hline & NEXPOWER & Taiwan & a-SiH & NB 150AN (1\% transp) & $\mathrm{X}$ & $X$ & $\mathrm{X}$ & OA2016 & $\mathrm{X}$ \\
\hline & NEXPOWER & Taiwan & a-SiH & NB $120 \mathrm{AS}$ (20\% transp) & $\mathrm{X}$ & $\mathrm{X}$ & $\mathrm{X}$ & $\mathrm{X}$ & 0 \\
\hline & SCHOTT SOLAR & Alemanha & Tandem a-Si/a-Si & $\begin{array}{l}\text { ASI THRU } 4 \text { I0 20\% } \\
\text { (2010) }\end{array}$ & $\mathrm{X}$ & $\mathrm{X}$ & 0 & $\mathrm{X}$ & 0 \\
\hline & SOLARWATT & Alemanha & Si-Mono & $\begin{array}{l}\text { 36M GLASS 160WP 20\% } \\
\text { (2015) }\end{array}$ & $\mathrm{X}$ & $\mathrm{X}$ & 0 & $X$ & 0 \\
\hline \multirow{9}{*}{$\begin{array}{c}\text { Módulo } \\
\text { fotovoltaico } \\
\text { opaco }\end{array}$} & CANADIAN & Canada & Si-Poli & CS 6P 265P (2013) & O5\% & $\mathrm{X}$ & 0 & OA2016 & 0 \\
\hline & CANADIAN & Canada & Si-Mono & CS 6P 265M (2013) & $05 \%$ & $\mathrm{X}$ & 0 & OA2016 & 0 \\
\hline & FIRST SOLAR & EUA & Filme F. CaTe & FS 41152 (2015) & O5\% & 0 & 0 & OA2016 & 0 \\
\hline & NEXPOWER & Taiwan & Tandem ucSi-aSiH & NT-160 AG (2011) & $\mathrm{X}$ & $X$ & 0 & OA2016 & 0 \\
\hline & NEXPOWER & Taiwan & a-SiH & NH-100AT 5A (2009) & $X$ & $\mathrm{X}$ & 0 & $\mathrm{X}$ & 0 \\
\hline & AVANCIS & Alemanha & Filme F. CIS & PowerMax 120 (2012) & $\mathrm{X}$ & $\mathrm{X}$ & 0 & OA2013 & $\mathrm{X}$ \\
\hline & AVANCIS & Alemanha & Filme F. CIS & $\begin{array}{c}\text { PowerMax } 3.5120 \\
(2015) \\
\end{array}$ & $X$ & $\mathrm{X}$ & 0 & $X$ & 0 \\
\hline & $\begin{array}{l}\text { SOLAR FRONTIER } \\
\end{array}$ & Alemanha & Filme F. CIS & SF-170 S (2013) & $\mathrm{X}$ & 0 & 0 & $\mathrm{X}$ & 0 \\
\hline & TSMC SOLAR & Alemanha & CIGS & TS 160 C1 (2015) & $\mathrm{X}$ & $\mathrm{X}$ & 0 & $\mathrm{X}$ & 0 \\
\hline
\end{tabular}

Fonte: Próprio autor (2016).

Onde:

Tecnologia: Si-Poli (silício policristalino), Si-Mono (silício monocristalino), a-SiH (silício amorfo hidrogenado), Fime F. (filme fino), CaTe (telureto de cadmio), ucSi (silício micro cristalino), CIS (disseleneto de cobre e índio - CuInSe2), CIGS (seleneto de cobre, índio, galio - CuInGaSe2);

Modelo: modelo do módulo fotovoltaico (entre parênteses o ano de início de comercialização e/ou grau de transparência do vidro); 
Relevância no mercado 2015: demarcados com circulo aqueles fabricantes que constam no Top Ten de fabricantes de células fotovoltaicas em 2015 (entre parênteses a participação no mercado) segundo Mints (2016);

Eficiência relevante 2016: demarcados com circulo aqueles fabricantes que constam na pesquisa Solar cell efficiency tables (GREEN et al, 2016) em sua edição de número 48 de maio de 2016 como maiores eficiências em suas tecnologias até janeiro de 2016;

BD do PVSYST: demarcados com circulo os modelos de módulos fotovoltaicos constantes do banco de dados do software PVSYST (PVSYST, mar/2016);

Tabela INMETRO: demarcados com circulo os modelos de módulos fotovoltaicos constantes da tabela de Eficiência Energética - Sistema de Energia Fotovoltaica - Módulos, do INMETRO edição 01/2016 de 31 de maio de 2016 (entre parênteses a classificação do selo e seu ano de aprovação pelo INMETRO);

Comercializado atualmente: demarcados com circulo aqueles módulos que estão sendo comercializados no momento (PVSYST, mar de 2016).

Observa-se na Tabela 5.4, que há dois agrupamentos com base no tipo de tecnologia: os vidros fotovoltaicos semitransparentes (BIPV glazing) e os módulos fotovoltaicos opacos $(B A P V)$. Os modelos simulados neste trabalho estão demarcados com a linha em cor cinza.

O primeiro grupo é formado pelos fabricantes Vidursolar, Schott Solar, Nexpower e SolarWatt. Essas tecnologias voltadas ao mercado de BIPV glazing ainda não possuem participação significativa no mercado mundial por serem mais recentes e por estarem ainda em busca de melhores resultados em eficiência. Pelos mesmos motivos ainda não constam na tabela do INMETRO. Sua seleção foi baseada principalmente na disponibilidade de dados no PVSYST database e no quesito de comercialização.

Os módulos da família FV VS C54 da espanhola Vidursolar são fabricados com células de silício poli cristalino depositadas entre dois vidros oferecendo uma transparência global entre 16 a $41 \%$. Neste trabalho foram simulados dois modelos: com $16 \%$ e $36 \%$ de fator de transparência.

Os vidros fotovoltaicos da Nexpower de Taiwan não foram selecionados para essa simulação, pois o único modelo que consta na tabela do INMETRO já não é mais comercializado.

Um dos principais fabricantes de produtos fotovoltaicos do mundo, a alemã Schott Solar oferece soluções com tecnologias de silício cristalino, de película fina e de módulos especiais à base de silício amorfo, estes últimos da linha ASI. O módulo selecionado para simulação é do tipo semitransparente com fator de $20 \%$ e é disponibilizado em forma laminada ou com 
vidros duplos. O semicondutor utilizado é composto por $99 \%$ de silício e livre de metais pesados como o cádmio, sendo aplicado em camadas muito finas $(<1 \mathrm{~mm})$ no vidro.

O modelo recente de vidro fotovoltaico da empresa alemã SolarWatt, série 36M Glass 160W com $20 \%$ de fator de transparência, também foi selecionado para simulação. Sua tecnologia é composta por células solares monocristalinas de alto desempenho dispostas entre dois vidros.

O grupo de tecnologias de módulos opacos é composto por dois dos maiores fabricantes mundiais: a Canadian Solar para os módulos rígidos de silício cristalino (mono e poli cristalino) e a First Solar, líder no segmento de filmes finos em telureto de cadmio. Esses, além do filme fino em sistema Tandem com silício da Nexpower e do filme fino de CIS da Avancis, constam na tabela do INMETRO. Como o modelo Power Max 120 da Avancis não é mais comercializado, foi selecionado um modelo similar (do mesmo fabricante) com início de comercialização mais recente (2015).

Foi simulado também outro fabricante com tecnologia de filme fino com CIS, a Solar Frontier da Alemanha, por se tratar de uma empresa de ponta nesse segmento, apresentando resultado relevante em eficiência em um de seus módulos, conforme citado no periódico Solar cell efficiency tables (GREEN et al, 2016) em sua edição de número 48 de maio de 2016.

A empresa alemã TSMC Solar foi selecionada pelo fato de ser um dos poucos registros de tecnologia CIGS no banco de dados do PVSYST e com o quesito de comercialização atendido. Essa tecnologia tem como principais características: rendimento adicional de energia devido ao efeito de imersão de luz, coeficiente de baixa temperatura que proporciona maior rendimento e conceito construtivo do módulo com vidro duplo.

\subsection{Definições básicas do sistema fotovoltaico (FV)}

A simulação das tecnologias, representadas pelos módulos selecionados, foi balizada por um procedimento que adotou como princípio básico a minimização de variáveis diferentes na composição do sistema fotovoltaico, a fim de facilitar a comparação dos resultados simulados. Esta etapa do trabalho teve por objetivo gerar resultados de geração de energia elétrica para cada tipo de tecnologia selecionada, quer seja em valores absolutos ou em forma de densidade de energia gerada por área ocupada pelo sistema fotovoltaico.

Assim, foi de suma importância a determinação das bases conceituais de projeto, conforme descritas a seguir. 


\subsubsection{Determinação das bases conceituais do projeto}

Esta etapa procurou determinar as características construtivas básicas do sistema como sendo as premissas para as simulações e alinhadas às exigências das regulamentações relativas à geração distribuída com compensação de energia elétrica.

A regulamentação relativa à geração distribuída $(\mathrm{RN}$ 482/2012) sofreu revisão com base na Resolução Normativa 687 da ANEEL com vigência a partir de março de 2016. Dentre outras alterações, essa resolução permitiu que os usuários integrantes de empreendimento de múltiplas unidades consumidoras possam aderir ao sistema de compensação de energia elétrica, e assim não se limitando aos circuitos de uso comum do condomínio.

Esse fato contribuiu para a ampliação do potencial de mercado para a adoção de sistemas de geração distribuída, com base em fonte solar fotovoltaica, por parte dos condomínios verticais. Assim, a base conceitual desta dissertação foi direcionada para esse foco.

\subsubsection{Disposição e arranjo do gerador fotovoltaico}

O grande desafio para a disseminação da tecnologia fotovoltaica em condomínios verticais, seja ela empresarial ou residencial, está no aproveitamento de suas fachadas, uma vez que há pouca disponibilidade de área livre nas coberturas ou nos áticos. Além disso, esses espaços são, muitas vezes, ocupados por elementos relacionados com o sistema hidráulico de água, ventilações, sistema de telecomunicações e sistema solar de aquecimento de água.

O aproveitamento da área de estacionamento de veículos com os módulos fotovoltaicos dispostos como cobertura é, na maioria dos condomínios verticais, inviabilizado devido ao efeito de sombreamento do próprio edifício ou de edificações vizinhas.

Assim, este trabalho optou por realizar simulações em um edifício hipotético com aproveitamento da fachada para a alocação dos módulos fotovoltaicos. Como o objetivo deste trabalho é realizar a comparação do desempenho de cada tecnologia fotovoltaica, foi adotado somente umas das fachadas, aquela voltada para o Norte geográfico, livre de elementos de sombreamento.

O edifício adotado para a simulação possui vinte andares além do piso térreo, com dimensões para habitação de famílias de classe média, conforme apresentado na Figura 5.3. 
Figura 5.3- Edifício hipotético com módulos fotovoltaicos na fachada

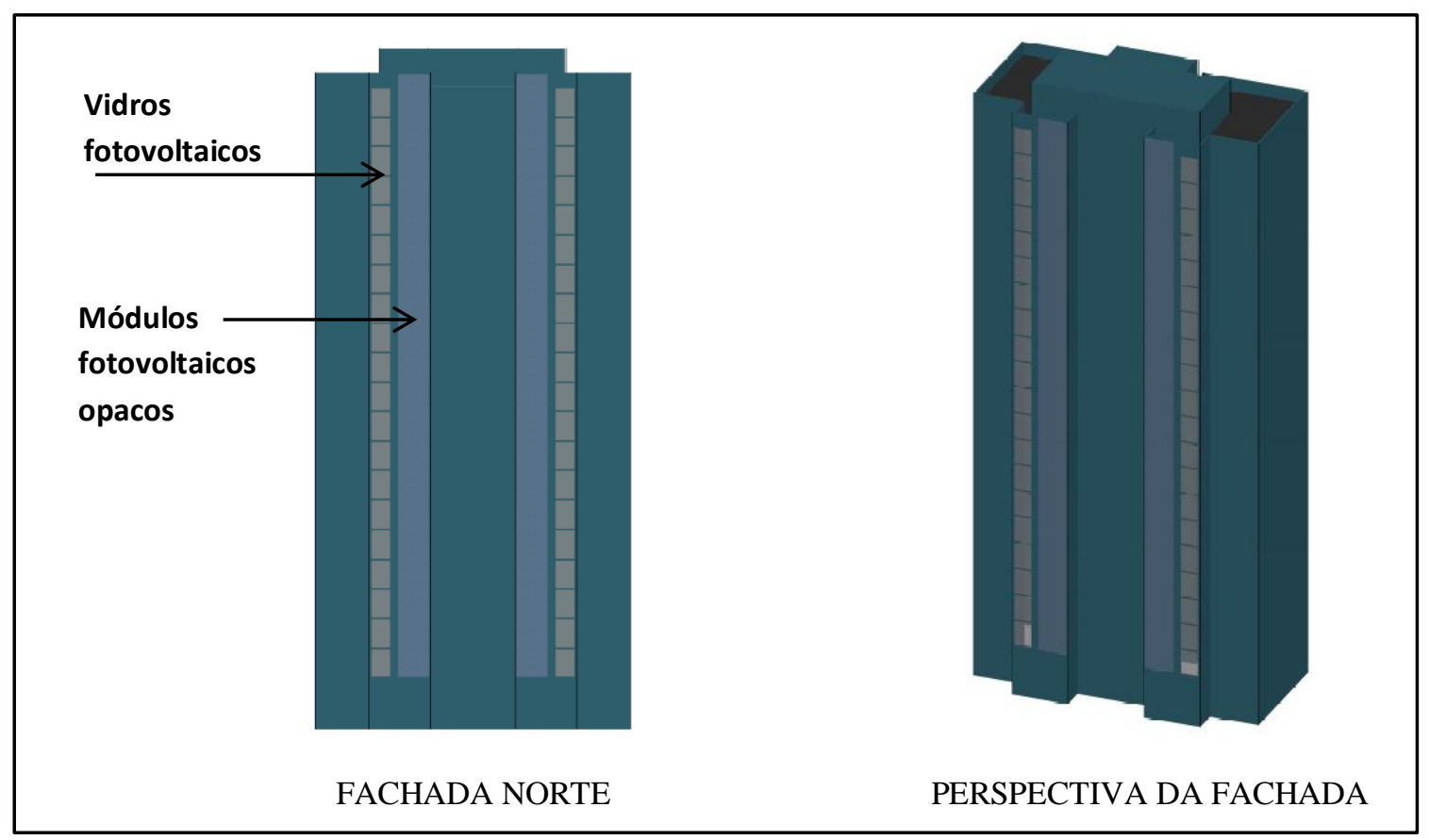

Fonte: Próprio autor (2016).

Observa-se na Figura 5.3 que a fachada Norte do edifício possui duas torres, sendo que cada uma delas disponibiliza uma área vertical frontal de $442 \mathrm{~m}^{2}$, com 68 metros de altura e 6,5 metros de largura. Essa área é dividida por uma parte da fachada que é cega e outra que é envidraçada (janelas).

Na porção da fachada cega foram simuladas as tecnologias com módulos opacos em forma de $B A P V$, sendo que os vidros fotovoltaicos semitransparentes foram alocados nas janelas $(B I P V$ glazing).

Dentro das aplicações em BIPV existem, atualmente, além dos vidros fotovoltaicos semitransparentes, alternativas para vedações verticais externas sem revestimento como fachada envidraçada e telhas fotovoltaicas. As telhas fotovoltaicas não são escopo deste trabalho uma vez que não são normalmente aplicáveis no caso de edifícios. As vedações verticais externas (fachadas do edifício) devem atender a vários requisitos normativos ou legais, aumentando significativamente o grau de complexidade desse tipo de aplicação, necessitando confrontar minuciosamente as referências e certificações internacionais de cada produto com as exigências normativas brasileiras, tais como: normas da Associação Brasileira de Normas Técnicas (ABNT), legislação em vigor regida pelo Código de Obras e Edificações do respectivo município, além das normas de segurança do Corpo de Bombeiros. Diante 
disso, definiu-se, dentre as aplicações em BIPV, somente a opção de vidros fotovoltaicos semitransparentes para aplicações em janelas para efeito deste trabalho.

\subsubsection{Definição das variáveis fixas do sistema fotovoltaico}

Com o intuito de amenizar a influência de variáveis de projeto na interpretação dos resultados finais deste trabalho, foram determinados alguns parâmetros fixos, comuns a todas as simulações exercitadas, conforme descritos a seguir.

\subsubsection{Dados de localização}

O local escolhido para o edifício hipotético foi o município de São Paulo por ser o maior centro urbano do País, porém apresentando um nível de irradiação solar diária média mensal abaixo da média entre as principais capitais brasileiras. Esse fato não foi relevante neste trabalho face ao seu objetivo principal que foi uma análise comparativa entre os resultados obtidos de cada tecnologia fotovoltaica.

Uma vez selecionado o município de São Paulo, a primeira variável introduzida no software PVSYST foi a sua localização geográfica, cujas coordenadas foram:

- São Paulo: Latitude $23,5^{\circ} \mathrm{S}$, Longitude $46,6^{\circ} \mathrm{W}$, Altitude 760 metros.

Isto determinou o percurso do Sol ao longo do ano e permitiu a interpolação dos dados meteorológicos da estação mais próxima do local com base nos registros do banco de dados Meteornorm, versão 7.1. Esses assuntos estão comentados nas subseções seguintes.

\subsubsection{Definição das variáveis locais}

Na Figura 5.4 pode-se visualizar a carta solar que mostra o posicionamento do caminho do Sol durante um ano para a localidade, com base no tempo solar. 
Figura 5.4 - Carta solar para o município de São Paulo - base tempo solar

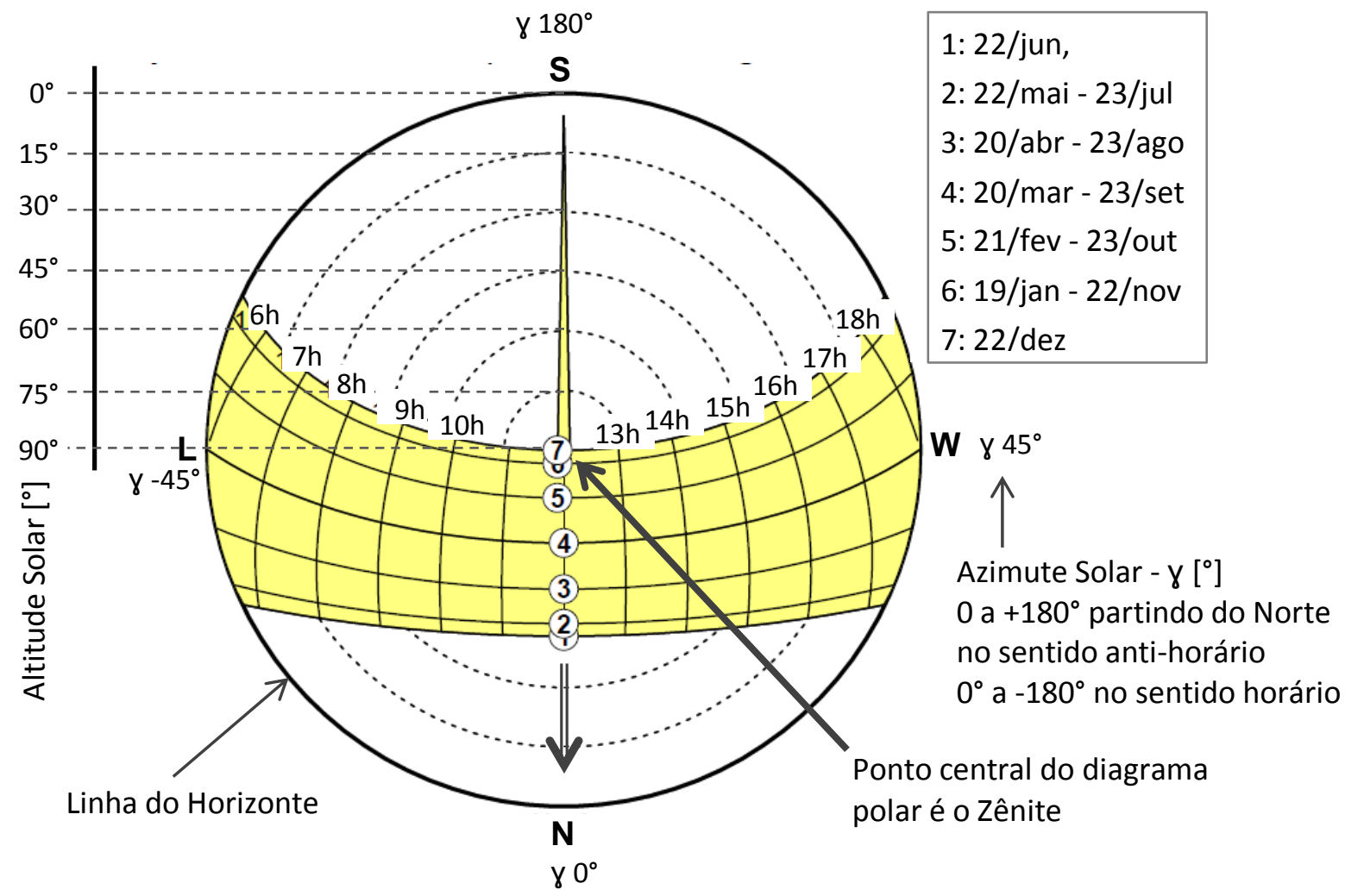

Fonte: adaptado do PVSYST com dados do Meteonorm 7.1 (2016).

A figura acima foi obtida do software PVSYST com algumas adaptações para uso em locais no hemisfério Sul: inversão das coordenadas Leste (L) e Oeste (W) e dos horários do dia. Ficou esclarecido que essas inversões foram aplicadas somente no desenho da carta solar, não necessitando intervir na simulação do software. O diagrama mostra uma formação de círculos concêntricos sendo que o círculo externo com linha mais espessa representa a linha do horizonte, vista por um observador localizado no ponto central do conjunto, denominado Zênite.

O desenho em 3D do edifício hipotético foi inserido no software PVSYST e posicionado de forma a centralizar o conjunto de módulos fotovoltaicos disposto em sua fachada, no ponto do Zênite, como mostrado na Figura 5.5. 
Figura 5.5- Edifício hipotético inserido e posicionado no software PVSYST

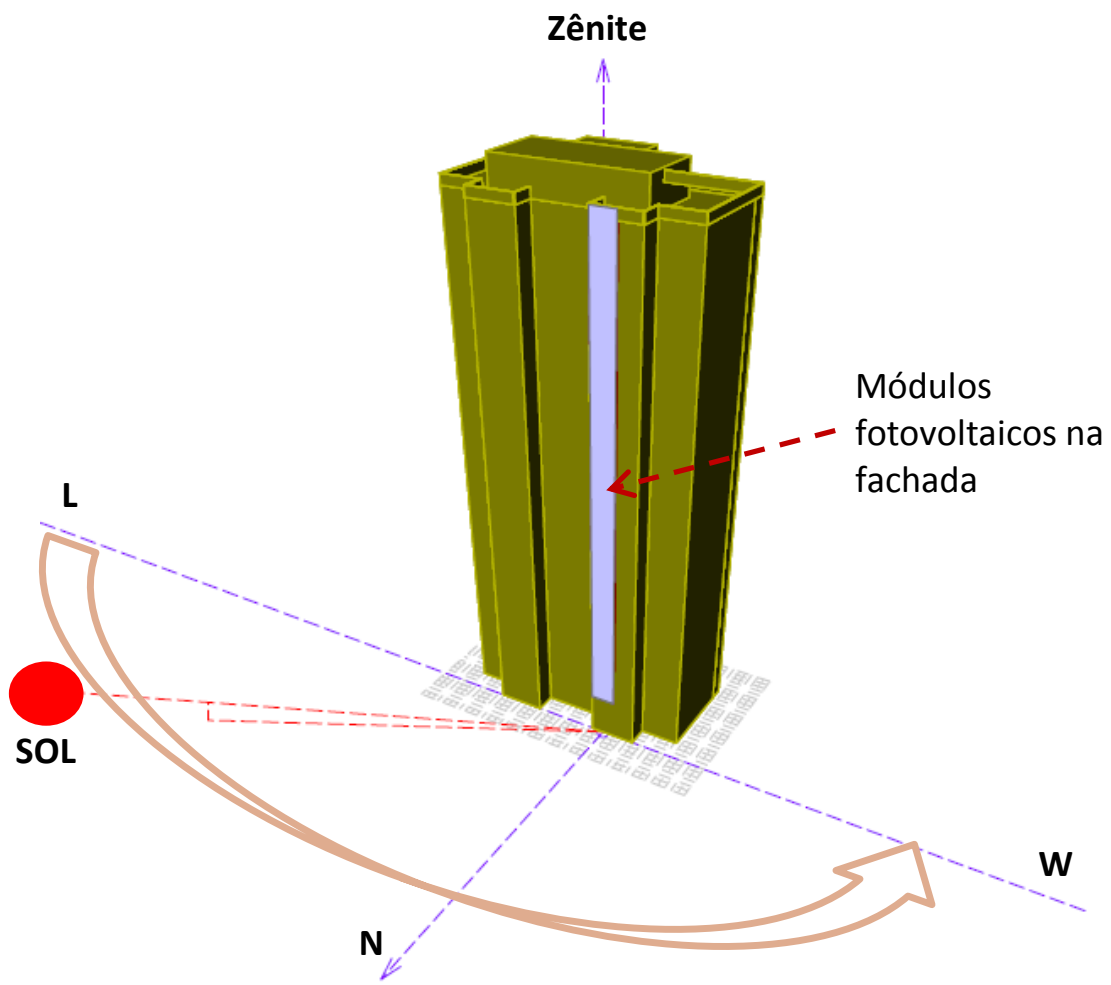

Fonte: Próprio autor com a plataforma do PVSYST (2016).

O ângulo de Azimute, tanto o Solar quanto o da superfície dos módulos fotovoltaicos, pelo conceito do software PVSYST ${ }^{52}$, estabelece o início na coordenada Norte, devendo estar contido no intervalo entre $-180^{\circ}$ a $+180^{\circ}$, negativo para o sentido horário. Como se pode visualizar na Figura 5.5, a fachada do edifício hipotético, ocupada pelos módulos fotovoltaicos, ficou orientada para o Norte que é o caso ideal em termos de incidência de radiação solar, e cujo ângulo de Azimute é $0^{\circ}$ seguindo o conceito do software utilizado para simulação.

Enquanto a linha do horizonte está relacionada com o ângulo de Azimute solar, as linhas pontilhadas estão com a altitude solar. Essas grandezas, que variam em função do horário e do dia do ano, têm influência principalmente sobre a eficiência do sistema fotovoltaico uma vez que os módulos foram dispostos de forma fixa sem seguidor solar ou sistema tracking ${ }^{53}$

\footnotetext{
${ }^{52}$ A referência do Azimute é diferente do que é normalmente praticado no Brasil. A referência “zero" no PVSYST é o Norte ao invés do Sul.

${ }^{53}$ Seguidor solar ou sistema tracking: sistema de automação eletromecânico que movimenta o gerador ou conjunto de módulos fotovoltaicos acompanhando o percurso do Sol, podendo ser de um ou dois eixos.
} 
Os dados meteorológicos da estação mais próxima do local foram obtidos do banco de dados Meteonorm, versão 7.1, sendo selecionados com a interação usuário-PVSYST, sendo mostrados na Tabela 5.5.

Tabela 5.5 - Variáveis meteorológicas do município de São Paulo

\begin{tabular}{cccccccccccccc}
\hline Variável & jan & fev & mar & abr & mai & jun & jul & ago & set & out & nov & dez & Ano \\
\hline $\begin{array}{c}\text { Irradiação } \\
\text { Global h }\end{array}$ & 139,8 & 139,7 & 125,7 & 107,9 & 98,8 & 88,5 & 99,6 & 115,2 & 112,2 & 124,8 & 149,7 & 140,6 & $1.442,5$ \\
\hline $\begin{array}{c}\text { Irradiação } \\
\text { Difusa } h\end{array}$ & 78,4 & 72,8 & 75,8 & 55,8 & 47,2 & 41,3 & 47,0 & 61,5 & 73,5 & 69,8 & 77,3 & 91,8 & 792,2 \\
\hline $\begin{array}{c}\text { Irradiação } \\
\text { Direta h }\end{array}$ & 61,4 & 66,9 & 49,9 & 52,1 & 51,6 & 47,2 & 52,6 & 53,7 & 38,7 & 55,0 & 72,4 & 48,8 & 650,3 \\
\hline $\begin{array}{c}\text { Temperatura } \\
\text { ambiente }\end{array}$ & 22,7 & 22,8 & 22,6 & 21,0 & 18,1 & 17,4 & 16,6 & 18,0 & 18,2 & 20,5 & 20,6 & 21,8 & 20,0 \\
\hline
\end{tabular}

Fonte: próprio autor com dados do Meteonorm 7.1 (2016).

Em que:

Irradiação Global h: irradiação global no plano horizontal [kWh/m².mês ou ano]; Irradiação Difusa h: irradiação difusa no plano horizontal [kWh/m².mês ou ano]; Irradiação Direta h: irradiação direta no plano horizontal [kWh/m².mês ou ano]; Temperatura ambiente: temperatura média mensal ou anual (bulbo seco) $\left[{ }^{\circ} \mathrm{C}\right]$.

A Tabela 5.5 apresenta os dados meteorológicos utilizados como variáveis fixas, isto é, variáveis cujos valores foram mantidos a todas as simulações, e consiste nas seguintes grandezas: irradiação solar global no plano horizontal, irradiação solar difusa no plano horizontal, irradiação solar direta no plano horizontal e temperatura ambiente média mensal. Neste trabalho foi considerada uma velocidade média e constante do vento de 1,5 m/s, cujo critério de escolha está descrito mais adiante.

Os níveis de radiação solar global incidente na superfície terrestre, ou irradiância solar global, sofrem atenuações em função de condições atmosféricas e variam conforme a hora e o dia do ano. Essa grandeza é resultado da soma de dois componentes: a irradiância ${ }^{54}$ direta (geralmente representada por Ib) e a difusa (normalmente representada por Id).

A porção de radiação solar incidente na superfície terrestre proveniente do efeito de espalhamento e de reflexão de elementos intervenientes compõe a radiação solar Difusa, que

\footnotetext{
${ }^{54}$ Irradiância (I): É o quociente entre o fluxo de energia incidente em uma superfície e a respectiva área de incidência deste elemento, com unidade em W/m².
} 
por sua vez tem uma relação direta com os efeitos de claridade do céu e de iluminação indireta do Sol, com base no índice de claridade tratado por Liu e Jordan (1960). Nota-se pela Tabela 5.5 que a fração de irradiação solar difusa, que soma 792,2 kWh/m²ano, corresponde a $55 \%$ da radiação global incidente na superfície terrestre, enquanto que a porção de irradiação direta participa em $45 \%$.

Segundo Grimm (1999), o efeito de espalhamento surge devido aos gases e aerossóis da atmosfera e é dependente do comprimento de onda e do tamanho de suas partículas, conforme Rayleigh.

De acordo com Grimm (1999), a parcela de radiação solar direta incidente na superfície terrestre corresponde a aproximadamente $25 \%$ do valor global incidente na atmosfera, enquanto a porção correspondente à energia solar refletida ao espaço é por volta de $30 \%$ já incluindo a porção retroespalhada. A parcela da radiação incidente que é refletida por uma superfície corresponde ao seu albedo, variável que depende da natureza da superfície e da altura do Sol. O albedo da atmosfera é representado de forma relevante pelos topos das nuvens, cujos valores podem variar entre $40 \%$ a $80 \%$ em função de sua espessura (GRIMM, 1999).

No conceito do software PVSYST o Albedo, ou coeficiente de reflexão, é a razão entre a radiação refletida pela superfície e a radiação incidente sobre ela. Expressa como uma percentagem numa escala que parte do zero, quando não há reflexão, e indo até $100 \%$ para o caso de reflexão perfeita. Segundo Mermoud et al (2014), áreas com areia ou neve possuem um alto albedo próximo de 0,9 , pois não absorvem a radiação, enquanto que locais de florestas e os oceanos possuem um albedo próximo de 0,2 , pois absorvem a radiação e refletem apenas uma parte dela. O albedo varia em função do comprimento de onda da radiação, no entanto, normalmente é adotado um valor médio ao longo do espectro da luz visível.

Para escolha do valor do albedo o software fornece parâmetros para referência dos tipos mais comuns de projeto, variando em função de suas condições e limitações, como mostrado na Tabela 5.6. 
Tabela 5.6 - Valores usuais para o albedo - base banco de dados do PVSYST

\begin{tabular}{cc}
\hline Características locais & Albedo [\%] \\
\hline Situação urbana & 14 a 22 \\
\hline Grama & 15 a 25 \\
\hline Grama fresca & 26 \\
\hline Neve fresca & 82 \\
\hline Neve molhada & 55 a 75 \\
\hline Asfalto seco & 9 a 15 \\
\hline Asfalto molhado & 18 \\
\hline Concreto & 25 a 35 \\
\hline Telhas vermelhas & 33 \\
\hline Alumínio & 85 \\
\hline Aço galvanizado novo & 35 \\
\hline Aço galvanizado muito sujo & 8 \\
\hline
\end{tabular}

Fonte: Mermoud et al (tradução nossa).

Nota-se pela tabela acima que o valor de albedo varia em função das características locais, sendo tanto maiores quanto mais favoráveis forem as condições para reflexão da radiação solar, como por exemplo, locais cobertos de neve e elementos em alumínio.

Em situações urbanas, como é o caso de São Paulo, o albedo do local pode variar entre 14\% a $22 \%$. Dessa forma, ficou estabelecido um valor de albedo de $20 \%$ para efeito deste trabalho, constante para todas as simulações.

O efeito das reflexões e desvios do ângulo de incidência da radiação solar sobre os módulos fotovoltaicos é tratado mais adiante, por se tratar de uma variável específica para cada tecnologia simulada.

\subsubsection{Posicionamento dos módulos fotovoltaicos}

Na função de gerenciamento das variáveis do sistema do software PVSYST, foram inseridos os dados relativos ao tipo de instalação dos painéis fotovoltaicos e os ângulos de inclinação e azimute da superfície, conforme mostrado na Figura 5.6. 


\section{Figura 5.6- Posicionamento dos módulos fotovoltaicos no software PVSYST}

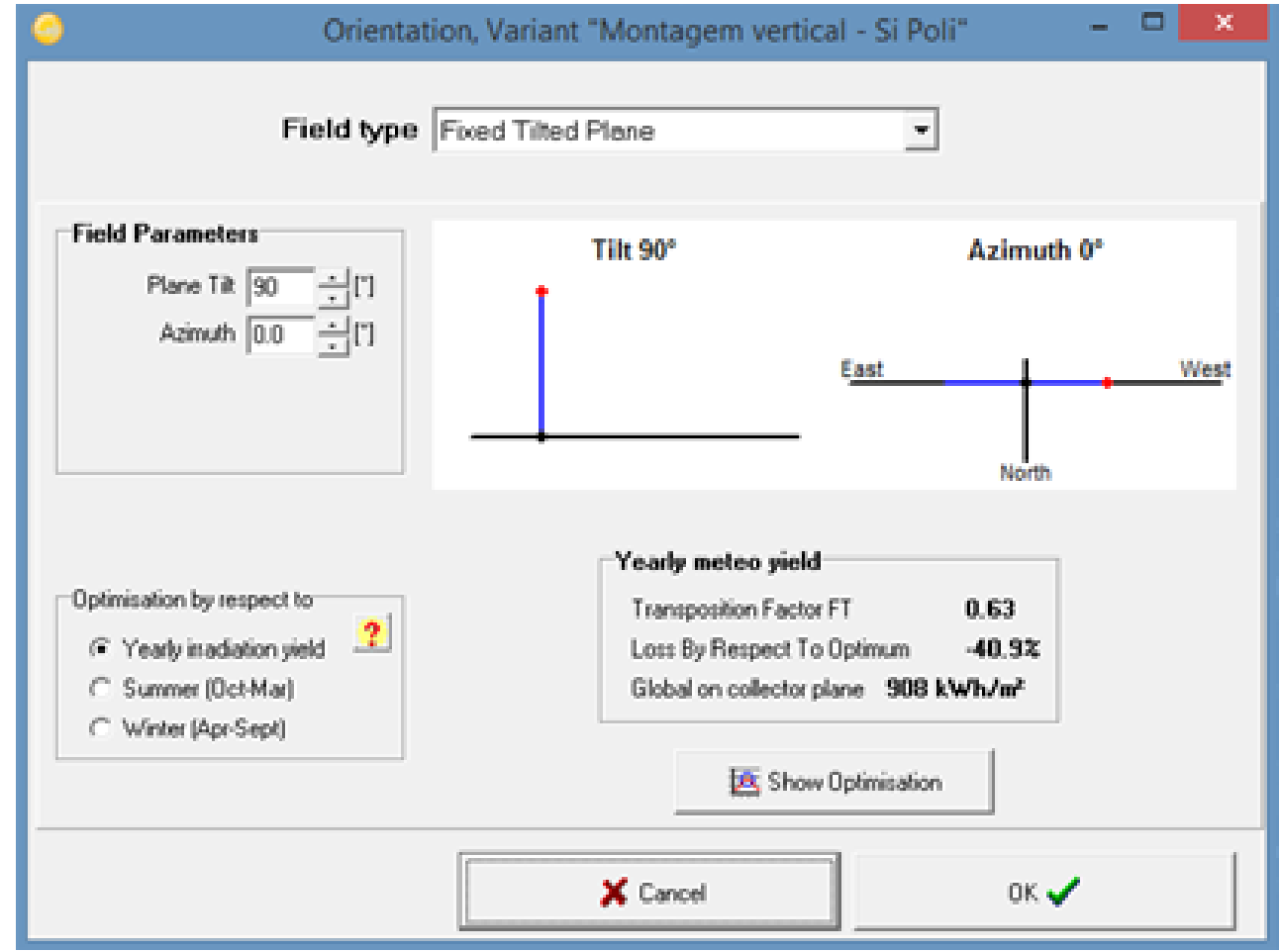

Fonte: PVSYST (2016)

Em que:

Field Type: tipo do arranjo dos módulos fotovoltaicos (plano com inclinação fixa);

Field Parameters: parâmetros do arranjo dos módulos fotovoltaicos;

Plane Tilt: ângulo de inclinação do plano de módulos $\left(90^{\circ}\right)$;

Azimuth: ângulo de azimute da superfície $\left(0^{\circ}=\mathrm{N}\right)$;

Optimization by respect to: considerar a melhor condição;

Yearly irradiation yield: produção annual de irradiação (opção selecionada);

Yearly meteo yield: desempenho annual dos fatores climáticos;

Transposition Factor FT: fator de transposição $(0,63)$;

Loss By Respect to Optimum: perda em relação a condição ótima $(-40,9 \%)$;

Global on collector plane: global sobre o plano do coletor $\left(908 \mathrm{kWh} / \mathrm{m}^{2}\right)$.

A Figura 5.6 mostra a tela do software PVSYST onde foram definidas as informações inerentes ao posicionamento dos módulos fotovoltaicos. Sua inclinação acompanhou paralelamente a fachada do edifício hipotético, isto é, $90^{\circ}$ (montagem vertical). O ângulo de azimute da superfície, como já comentado anteriormente, ficou orientado a $0^{\circ}$ obedecendo ao conceito do software, ou seja, sua face voltada para o Norte. Esses valores foram constantes para todas as tecnologias simuladas. 
Foi estabelecido o modo de montagem fixa, sem adoção de sistema de seguidor solar, dispondo os módulos fotovoltaicos, no caso dos opacos, de forma paralela a vedação vertical da fachada do edifício e mantendo uma distância para circulação de ar com a finalidade de reduzir a influência dos efeitos térmicos sobre a eficiência do sistema. Já os vidros semitransparentes foram justapostos a vedação vertical na mesma face da edificação, em substituição as janelas.

Assim foram determinados dois modos de montagem dos módulos fotovoltaicos: o primeiro afastado a certa distância da vedação do edifício e o outro justaposto como janela na fachada. Ambos estão relacionados com a questão da temperatura da célula e sua eficiência.

O comportamento térmico do local tem uma grande influencia no desempenho elétrico dos módulos fotovoltaicos, e pode ser analisado pelo balanço de energia entre a temperatura ambiente e a de aquecimento da célula devido à radiação incidente, expresso da seguinte forma:

$$
\text { U. }(\text { Tcel }- \text { Tamb })=\alpha . \text { Ginc. }(1-\text { efic })
$$

Em que:

$\mathrm{U}$ : fator de perda térmica (ou antigo valor-K) em $\left[\mathrm{W} / \mathrm{m}^{2} \mathrm{~K}\right]$;

$\alpha$ : coeficiente de absorção da radiação solar, usualmente 0,9 ;

efic: eficiência do módulo fotovoltaico, da especificação do fabricante;

Ginc: irradiância solar local no plano horizontal em W/m²;

Tcel: temperatuta da célula em [K];

Tamb: temperatura ambiente em $[\mathrm{K}]$.

O fator de perda térmica, denominado valor $\mathrm{U}$, é composto por um componente constante (Uc) e um fator que é proporcional à velocidade do vento (Uv):

$$
\mathbf{U}=\mathbf{U} \mathbf{c}+\mathbf{U v} \cdot \mathbf{v}
$$

Em que:

Uc: constante em $\left[\mathrm{W} / \mathrm{m}^{2} \mathrm{k}\right]$;

Uv: fator de perda térmica proporcional à velocidade do vento em $\left[\mathrm{W} / \mathrm{m}^{2} \mathrm{~K}\right]$;

$\mathrm{v}$ : velocidade do vento em $[\mathrm{m} / \mathrm{s}]$.

Esses fatores variam em função do modo em que são instalados os módulos fotovoltaicos: com livre circulação de ar em todas as faces dos módulos, semi-integrados à construção com 
passagem de ar em sua face posterior ou integrado à construção com sua face posterior isolada do ambiente externo.

Para situações em que há livre circulação de ar nas duas faces do módulo, esse coeficiente deve ser duplicado. Se a parte posterior do módulo estiver isolada termicamente, esse deve ser reduzido pela metade, pois a face posterior não participa da convecção térmica.

O banco de dados do PVSYST possui registros dos coeficientes Uc e Uv provenientes de medições em campo, porém mais voltados para os casos de arranjos montados com faces livres, por se tratar do modo mais usualmente aplicado mundialmente. Além disso, no caso dos módulos semi-integrados, pode haver grande diferença no valor do fator U entre as regiões do arranjo: próximas da entrada de ar e da saída. Com o objetivo de simplificar a análise comparativa de desempenho das tecnologias simuladas, essa diferença de temperatura do arranjo não foi computada.

Outra questão é relativa ao conhecimento de forma confiável da velocidade do vento no nível onde se encontram os módulos fotovoltaicos. Esses geralmente são dispostos em alturas diferentes daquelas referenciais das medições registradas no banco de dados Meteonorm, cujo padrão é a 10 metros de altura em ambiente livre. Assim, não se pode aplicar o mesmo valor de Uv para ambos os casos. Nesta simulação ficou estabelecido o valor de Uv em "zero".

Nesse caso, o software PVSYST transfere a contribuição dependente do vento ao fator Uc, assumindo uma velocidade média e constante do vento de $1,5 \mathrm{~m} / \mathrm{s}$.

Essa condição foi adotada em todas as simulações exercitadas neste trabalho, sendo que os valores de Uc ficaram estabelecidos com base nas recomendações citadas no software, ou seja:

- $\mathrm{Uc}=29 \mathrm{~W} / \mathrm{m}^{2} \mathrm{~K}$ para os arranjos com circulação de ar em torno dos módulos;

- $\mathrm{Uc}=20 \mathrm{~W} / \mathrm{m}^{2} \mathrm{~K}$ para módulos semi-integrados com passagem de ar em sua face posterior;

- $\mathrm{Uc}=15 \mathrm{~W} / \mathrm{m}^{2} \mathrm{~K}$ para módulos integrados à construção.

Diante disso, as tecnologias abrangidas neste trabalho foram classificadas em função do modo em que os módulos são dispostos na fachada do edifício, conforme abaixo:

- $\mathrm{Uc}=20 \mathrm{~W} / \mathrm{m}^{2} \mathrm{~K}$ : aplicado às tecnologias de módulos opacos, montados sobre suportes vazados na fachada do edifício a certa distância. Classificados como semi-integrados à construção; 
- $\mathrm{Uc}=15 \mathrm{~W} / \mathrm{m}^{2} \mathrm{~K}$ : aplicado às tecnologias de vidros semitransparentes, montados de forma justaposta na fachada, nas aberturas para janelas. Classificados como integrados à construção.

Relacionando essa classificação do modo de montagem do arranjo fotovoltaico com as afirmações de Jelle (2015), pode-se dizer que os sistemas integrados são chamados Building Integrated Photovoltaic (BIPV) Systems, pois substituem um dos elementos construtivos do edifício, isto é, os vidros das janelas. Enquanto que os sistemas semi-integrados são relacionados com o Building Attached Photovoltaic (BAPV) Systems, considerados como partes complementares dos edifícios, e, portanto, não diretamente relacionados com os aspectos funcionais das estruturas da edificação.

O Fator de Transposição, tratado no software PVSYST, pode variar em função da orientação e da inclinação dos módulos do sistema fotovoltaico, fornecendo informações relacionadas à quantidade de radiação incidente nos módulos fotovoltaicos.

Esse fator pode ser obtido pela seguinte equação:

$$
\text { FT }=\text { Ginc/Ghor }
$$

Em que:

Ginc: irradiação global incidente no plano do coletor;

Ghor: irradiação global no plano horizontal.

Pelo fato do arranjo fotovoltaico estar disposto com um ângulo de inclinação de $90^{\circ}$, o seu fator de transposição (FT) ficou em 0,63 ou $63 \%$.

\subsubsection{Definição das variáveis específicas de cada tecnologia fotovoltaica}

\subsubsection{Fator modificador do ângulo de incidência}

O efeito das reflexões e desvios do ângulo de incidência da radiação solar sobre os módulos fotovoltaicos é tratado pelo software PVSYST sob o termo chamado de fator modificador do ângulo de incidência (Fator IAM), que corresponde à porção reduzida de irradiância que realmente atinge a superfície das células fotovoltaicas, em relação à irradiância sob uma condição de incidência normal. 
Esse fenômeno obedece às leis de Fresnel no que tange a transmissão e a reflexão na interface de dois materiais transparentes com diferentes índices de refração, permitindo avaliar o efeito na interface da camada protetora do módulo (normalmente um vidro) com a superfície das células fotovoltaicas, depositadas em revestimento antirreflexivo ou transparente.

A American Society of Heating, Refrigerating and Air-Conditioning Engineers (ASHRAE $\left.{ }^{55}\right)$ estabeleceu uma parametrização para o cálculo dessa perda de incidência em função do ângulo de incidência sobre o plano e o índice de refração da superfície, conforme a expressão abaixo.

\section{$\operatorname{FIAM}=1-$ bo $\bullet(1 / \cos \mathbf{i}-1)$}

Onde:

i: ângulo de incidência sobre o plano;

bo: índice de refração da superfície.

Para os módulos solares térmicos com vidros simples é adotado um valor de bo por volta de 0,1 , enquanto que para um módulo fotovoltaico cristalino é normalmente 0,05 , devido à sua interface inferior, que em contato com a célula, apresenta um índice de refração elevado.

Nas simulações efetuadas foram adotados os valores de cada tecnologia fotovoltaica, com base nas especificações de fabricantes cadastrados no banco de dados do PVSYST.

O fator de IAM relacionado à radiação difusa também foi considerado nas simulações, o que contribuiu nos períodos de baixa incidência solar.

\subsubsection{Seleção do inversor}

Foi adotado o fabricante de inversores Fronius por alguns motivos: estabelecido no Brasil com disponibilidade de treinamentos, assessoria e assistência técnica. Além disso, possui produtos certificados pelo Instituto Nacional de Metrologia, Qualidade e Tecnologia (INMETRO) e tecnologias compatíveis com parâmetros elétricos brasileiros.

A escolha do inversor adequado em cada simulação sempre deve ser sincronizada com os parâmetros elétricos do gerador fotovoltaico, tais como: Voc, Vmpp, Vmaxcc, Vnom, quantidade de strings, módulos em série etc.

\footnotetext{
${ }^{55}$ Sociedade global fundada em 1984, com foco em sistemas de construção, eficiência energética, qualidade do ar interior, refrigeração e sustentabilidade.
} 
Além disso, na busca do conjunto mais adequado do sistema para cada tecnologia simulada, isto é, arranjo dos módulos e inversores, foram efetuadas tantas tentativas quanto necessárias para resultar no atendimento a todos os requisitos técnicos. Em função disso, a área do arranjo físico do gerador fotovoltaico foi ajustada para cada tipo de tecnologia.

O Fator de Dimensionamento do Inversor (FDI) não variou significativamente entre os casos simulados. Procurou-se também manter bem próximos os valores de potência nominal dos inversores individuais para cada caso simulado.

A Tabela 5.7 mostra um resumo da composição final de cada sistema fotovoltaico simulado.

Tabela 5.7- Composição dos sistemas fotovoltaicos por tecnologia

\begin{tabular}{|c|c|c|c|c|c|}
\hline Tecnologia de módulo FV & Inversor & Arranjo FV & $\begin{array}{l}\text { Potência } \\
\text { CA }(k W)\end{array}$ & $\begin{array}{c}\text { Potência } \\
\text { CC } \\
(\mathrm{kWp})\end{array}$ & FDI \\
\hline Si-Mono (rígido) & $6 \times 4,5 \mathrm{~kW}$ & $126 \times 265 \mathrm{Wp}$ & 27 & 33,4 & $80,8 \%$ \\
\hline Si-Poli (rígido) & $6 \times 4,5 \mathrm{~kW}$ & $126 \times 265 \mathrm{Wp}$ & 27 & 33,4 & $80,8 \%$ \\
\hline CaTe (Filme Fino) & $6 \times 4,5 \mathrm{~kW}$ & $280 \times 115 \mathrm{Wp}$ & 27 & 32,2 & $83,9 \%$ \\
\hline ucSi-aSiH (Filme Fino) & $4 \times 4,6 \mathrm{~kW}$ & $132 \times 160 \mathrm{Wp}$ & 18,4 & 21,12 & $87,1 \%$ \\
\hline CIS (Filme Fino) AV & $4 \times 4,5 \mathrm{~kW}$ & $180 \times 120 \mathrm{Wp}$ & 18 & 21,6 & $83,3 \%$ \\
\hline CIS (Filme Fino) SF & $5 \times 4,5 \mathrm{~kW}$ & $160 \times 170 \mathrm{Wp}$ & 23 & 27,2 & $84,6 \%$ \\
\hline CIGS (Filme Fino) & $6 \times 4,6 \mathrm{~kW}$ & $198 \times 160 \mathrm{Wp}$ & 28 & 31,7 & $88,3 \%$ \\
\hline Vidro FVST (Si-Poli, 36\%) & $3 \times 4,6 \mathrm{~kW}$ & $90 \times 180 \mathrm{Wp}$ & 13,8 & 16,2 & $85,2 \%$ \\
\hline Vidro FVST (Si-Poli, 16\%) & $4 \times 4,6 \mathrm{~kW}$ & $176 \times 120 \mathrm{Wp}$ & 18,4 & 21,12 & $87,1 \%$ \\
\hline Vidro FVST (a-Si, 20\%) & $2 \times 4 \mathrm{~kW}$ & $72 \times 140 \mathrm{Wp}$ & 8 & 10,08 & $79,4 \%$ \\
\hline Vidro FVST (Si-Mono, 20\%) & $6 \times 4,5 \mathrm{~kW}$ & $210 \times 160 \mathrm{Wp}$ & 27 & 33,6 & $80,4 \%$ \\
\hline
\end{tabular}

Fonte: próprio autor (2016).

Observa-se que, no intuito de minimizar as influências do inversor na análise comparativa dos resultados de geração de energia, procurou-se selecionar aqueles cujas características técnicas e funcionais não divergissem significativamente. Portanto, os inversores adotados nas simulações variam entre 4,0 kW a 4,6 kW. No entanto, a quantidade de inversores variou em função das características técnicas do arranjo fotovoltaico de cada tecnologia de módulos.

Note-se também que o FDI teve uma variação dentro de uma faixa entre 79,4\% e 88,3\%, na tentativa de equalizar o comportamento do conjunto arranjo-inversor em relação ao seu ponto de máxima potência. 


\subsection{Etapa de simulações}

\subsubsection{As principais funções do software}

Como já apresentado em subseção anterior, o Software dispõe de quatro funções principais, sendo:

A primeira função é para um estudo preliminar ou Preliminary design que permite uma rápida avaliação das potencialidades e possíveis restrições de um projeto fotovoltaico sob determinadas condições, contudo sua precisão é limitada.

A função de desenvolvimento do projeto ou Project design, parte principal do software, é uma ferramenta para o estudo completo de um projeto fotovoltaico, envolvendo: escolha de dados meteorológicos, desenho do sistema, estudo de sombreamento, determinação das perdas do sistema e apoio à análise econômica. Permite a simulação em regime horário por um período de um ano e fornece relatórios das simulações e dos resultados. As simulações foram realizadas nesse ambiente de Project design para sistemas conectados à rede (Gridconnected).

Com a finalidade de fornecer subsídios às funções anteriores, a base de dados ou Databases é formada por um banco de dados contendo registros climáticos horários e mensais, valores horários sintetizados e possibilita a importação de dados provenientes de outras bases externas.

A última função que é a de ferramentas do software ou Tools auxilia na estimativa e na visualização do comportamento de um sistema fotovoltaico. Além disso, permite importar resultados de desempenho de instalações existentes para compará-los com a simulação.

\subsubsection{Dados de entrada}

A tela inicial para inserção de dados no software é composta por dois grupos: um relativo às definições básicas do projeto e outro de gerenciamento de variáveis do sistema. Esse assunto já foi abordado nas subseções anteriores, mas pode ser visualizado esquematicamente na Figura 5.7. 
Figura 5.7 - Diagrama esquemático das variáveis de entrada do software PVSYST

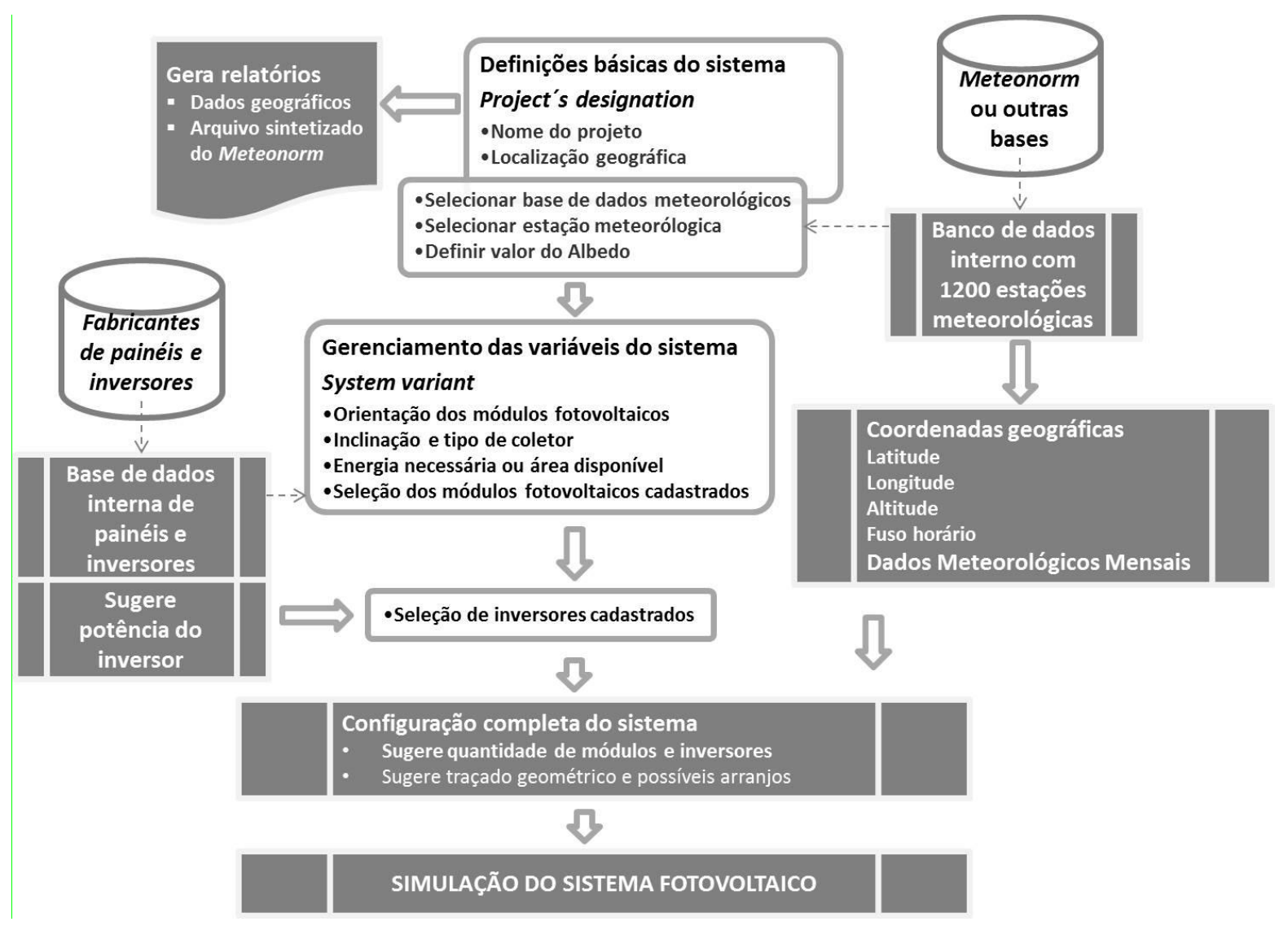

Fonte: Próprio autor com base nas informações do manual do software PVSYST 6 (2015).

Conforme já explicitado nas subseções anteriores, as primeiras variáveis de entrada do PVSYST foram a denominação do projeto e sua localização geográfica com base no município de São Paulo, permitindo dessa forma a interpolação dos dados meteorológicos da estação mais próxima do local.

Foi adotada como base das simulações a fonte de dados meteorológicos built-in do PVSYST que é o programa Meteonorm.

$\mathrm{Na}$ função de gerenciamento das variáveis do sistema, foi estabelecido o tipo de instalação com painéis fotovoltaicos planos inclinados e fixos e determinados os ângulos de inclinação em $90^{\circ}$ e de azimute da superfície em $0^{\circ}$.

Os módulos fotovoltaicos foram selecionados do banco de dados do PVSYST de modo a compor um conjunto heterogêneo de tecnologias, a fim de comparar seus resultados de desempenho. $\mathrm{O}$ inversor foi escolhido, para cada caso simulado, em função da configuração do arranjo de módulos fotovoltaicos para se obter um aproveitamento próximo do Ponto de Máxima Potência (PMP) com um Fator de Dimensionamento do Inversor (FDI) em torno de $80 \%$. 
Uma vez inserida a base conceitual do projeto, foi determinado um valor referencial de área disponível na fachada do edifício para instalação do gerador fotovoltaico, entre 200 a $210 \mathrm{~m}^{2}$, localizada em uma das torres frontais.

\subsubsection{Simulações}

A simulação foi realizada para cada uma das tecnologias fotovoltaicas definidas, com uma interação com o usuário para avaliações dos resultados parciais e ajustes necessários.

A Figura 5.8 mostra um diagrama esquemático do processo de simulação sucessiva relacionado com variáveis adicionais ou detalhes específicos do sistema.

Figura 5.8- Diagrama esquemático das simulações sucessivas e variáveis adicionais

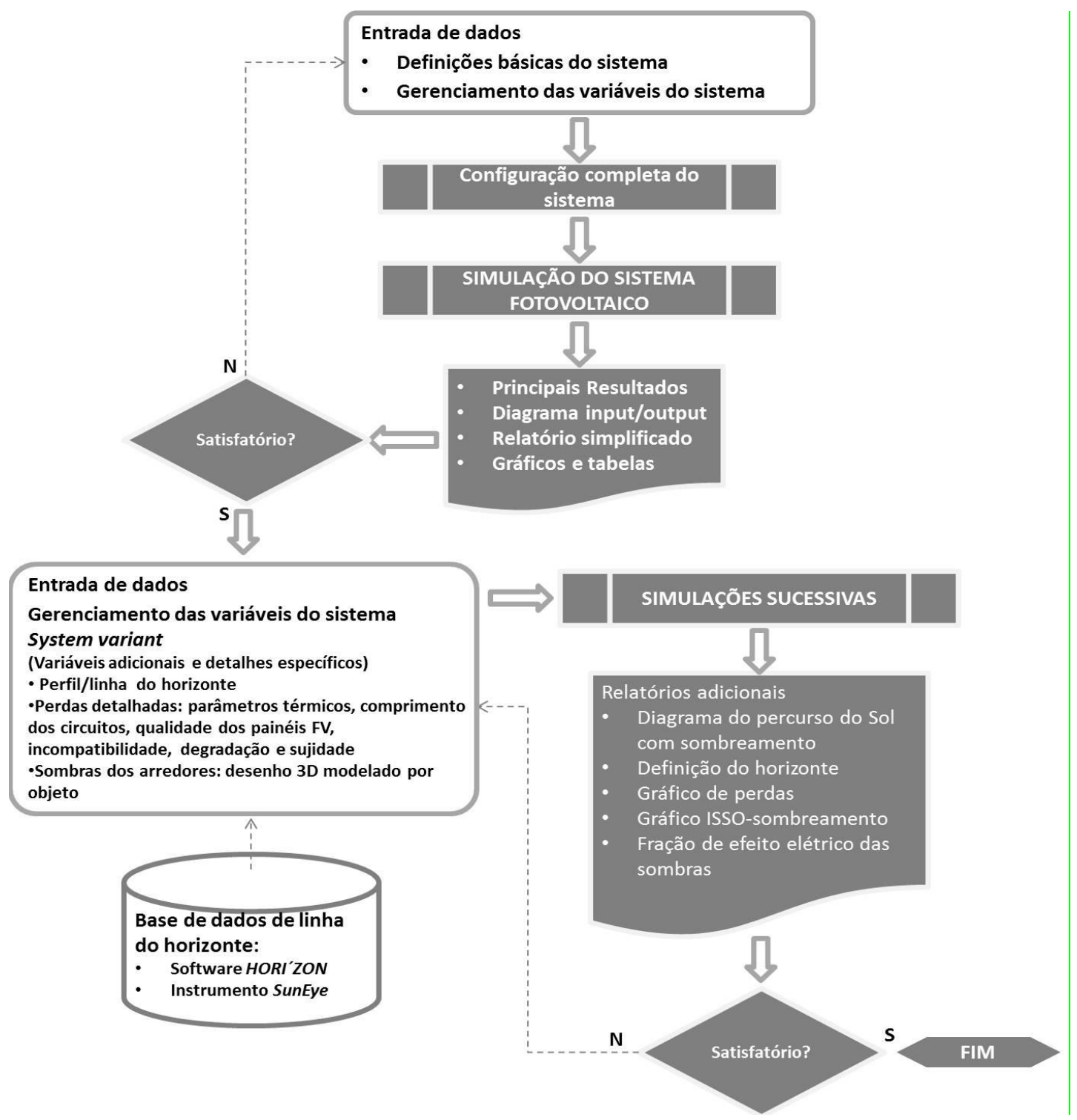

Fonte: Próprio autor com base nas informações do manual do software PVSYST 6 (2015). 
Uma vez definida toda a configuração do sistema efetuou-se a simulação de cada tecnologia, sendo que seus resultados forneceram subsídios para análise e ajustes em sintonia com as variáveis da função de gerenciamento das variáveis do sistema. Esses resultados foram mostrados na forma de diagramas, tabelas, gráficos e relatórios, os quais são comentados na subseção de resultados e discussões.

Na etapa de simulação sucessiva foram ajustadas algumas variáveis adicionais relativas ao fator de sombreamento e às perdas detalhadas do sistema, permitindo dessa forma uma avaliação de sua influência do desempenho de geração de energia elétrica do sistema fotovoltaico. O efeito de sombreamento teve uma influência irrelevante no desempenho do sistema, por dois motivos: o edifício hipotético não possui elementos de sombreamento no entorno e nem elementos construtivos que possam causar sombreamento sobre o arranjo fotovoltaico. Algumas exceções foram observadas próximo aos horários do nascer e do por do Sol em certas épocas do ano.

As variáveis relacionadas às perdas do sistema, como perdas térmicas, perdas Ôhmicas do circuito de corrente contínua $(\mathrm{CC})$ e perdas por fator modificador do ângulo de incidência (Fator IAM), foram ajustadas para avaliação de resultados adicionais. 


\section{RESULTADOS E DISCUSSÃO}

\subsection{Resultados das simulações}

\subsubsection{Diagrama funcional e resumo dos resultados}

A Figura 6.1 mostra o diagrama funcional básico do sistema fotovoltaico adotado nas simulações.

Figura 6.1 - Diagrama funcional básico do sistema fotovoltaico

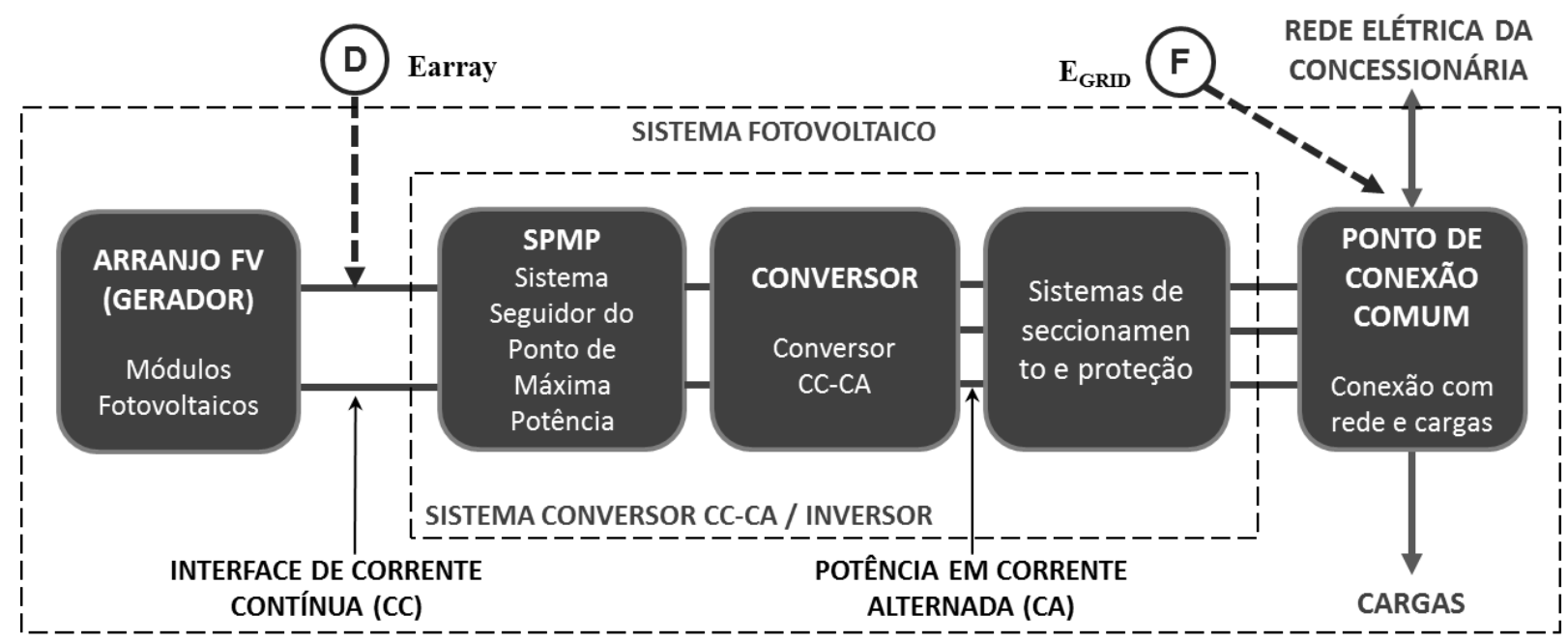

Fonte: Próprio autor (2016).

O diagrama funcional mostra os pontos no sistema onde foram obtidos os resultados principais das simulações. A energia elétrica gerada pelo gerador fotovoltaico (arranjo dos módulos) foi registrada no ponto D da figura, onde é a interface de corrente contínua (CC) do sistema, na unidade $\mathrm{kWh}$ mensal e totalizado no ano. A energia injetada na rede elétrica da Concessionaria, em corrente alternada (CA), foi medida no ponto $\mathrm{F}$, em $\mathrm{kWh}$ mensal e totalizado no ano.

A Tabela 6.1 resume e compara os resultados simulados. 
Tabela 6.1 - Resumo dos resultados - Energia anual gerada por tecnologia

\begin{tabular}{|c|c|c|c|c|c|}
\hline Fabricante & Tecnologia & $\begin{array}{c}\text { Energia de Saída } \\
\text { do Gerador } \\
(E \text { array })\end{array}$ & $\begin{array}{c}\text { Energia Injetada } \\
\text { na Rede } \\
(E \text { Grid }) \\
\end{array}$ & $\begin{array}{c}\text { Eficiência } \\
\text { do Gerador } \\
(\text { Eff } \text { ArrR })\end{array}$ & $\begin{array}{r}\text { Eficiência } \\
\text { do Sistema } \\
(\text { Eff SysR }) \\
\end{array}$ \\
\hline & & $\mathrm{kWh} / \mathrm{ano}$ & $\mathrm{kWh} / \mathrm{ano}$ & $\%$ & $\%$ \\
\hline Canadian & Si-Mono (rígido) & $25.604,00$ & $24.710,00$ & 14,70 & 14,19 \\
\hline Canadian & Si-Poli (rígido) & $25.583,00$ & $24.692,00$ & 14,69 & 14,18 \\
\hline First Solar & CaTe (Filme Fino) & $23.722,00$ & $22.916,00$ & 13,70 & 13,23 \\
\hline Nexpower & ucSi-aSiH (Filme Fino) & $16.107,00$ & $15.003,00$ & 9,22 & 8,59 \\
\hline Avancis & CIS (Filme Fino) AV & $15.748,00$ & $15.185,00$ & 9,66 & 9,32 \\
\hline Solar Frontier & CIS (Filme Fino) SF & $21.130,00$ & $20.359,00$ & 12,52 & 12,06 \\
\hline TSMC Solar & CIGS (Filme Fino) & $23.327,00$ & $21.712,00$ & 12,62 & 11,75 \\
\hline Vidursolar & Vidro FVST (Si-Poli, 36\%) & $11.840,00$ & $11.025,00$ & 6,98 & 6,50 \\
\hline Vidursolar & Vidro FVST (Si-Poli, 16\%) & $15.454,00$ & $14.386,00$ & 8,87 & 8,26 \\
\hline Schott Solar & Vidro FVST (a-Si, 20\%) & $7.164,10$ & $6.765,80$ & 3,95 & 3,73 \\
\hline SolarWatt & Vidro FVST (Si-Mono, 20\%) & $25.159,00$ & $24.259,00$ & 12,92 & 12,46 \\
\hline
\end{tabular}

Fonte: Próprio autor (2016).

Em que:

Si-Mono (rígido): módulo rígido de células de silício monocristalinas;

Si-Poli (rígido): módulo rígido de células de silício policristalinas;

CaTe (Filme Fino): Filme Fino de telureto de cádmio;

ucSi-aSiH (Filme Fino): Filme Fino de silício microcristalino e silício amorfo hidrogenado em montagem Tandem;

CIS (Filme Fino) AV: Filme Fino de seleneto de cobre e índio do fabricante Avancis;

CIS (Filme Fino) SF: Filme Fino de seleneto de cobre e índio do fabricante Solar Frontier;

CIGS (Filme Fino): Filme Fino de disseleneto de cobre, índio e gálio;

Vidro FVST (Si-Poli, 36\%): vidro fotovoltaico semitransparente com células de silício policristalino e $36 \%$ de fator de transparência;

Vidro FVST (Si-Poli, 16\%): vidro fotovoltaico semitransparente com células de silício policristalino e $36 \%$ de fator de transparência;

Vidro FVST (a-Poli, 20\%): vidro fotovoltaico semitransparente com células de silício amorfo e $20 \%$ de fator de transparência;

Vidro FVST (Si-Mono, 20\%): vidro fotovoltaico semitransparente com células de silício monocristalino e $20 \%$ de fator de transparência.

Observa-se na Tabela 6.1 os resultados de energia em corrente contínua produzida pelo gerador fotovoltaico (arranjo de módulos), com a nomenclatura Earray no PVSYST, que alimenta o sistema conversor CC-CA (inversor). Esse, por sua vez, transforma a energia 
recebida de corrente contínua em corrente alternada, injetando-a na rede de distribuição elétrica da Concessionária, denominada de E Grid no PVSYST.

Esses resultados apresentaram valores que variaram, principalmente, em função da tecnologia aplicada de módulos fotovoltaicos, de seu arranjo e do inversor selecionado. No entanto, algumas condições iniciais foram comuns a todas as tecnologias simuladas, a saber:

- Irradiação global mensal no plano horizontal (GlobHor), totalizando 1.442,50 kWh/m²ano;

- Temperatura ambiente média mensal, cuja média anual foi de $20,02^{\circ} \mathrm{C}$;

- Irradiação global mensal incidente no coletor plano após fator de transposição, mas sem correções óticas, somando 859,20 kWh/m²ano (GlobInc).

Vale lembrar que já foram explanados nas subseções anteriores outros aspectos que foram comuns a todas as simulações: montagem vertical dos módulos na fachada do edifício em São Paulo, ângulo de azimute da superfície $(\gamma)$ de $0^{\circ}$ pelo critério do PVSYST, ângulo de inclinação da superfície $(\beta)$ de $90^{\circ}$.

A eficiência do gerador fotovoltaico, representada por EffarrR no PVSYST, foi obtida dividindo-se o valor da energia de saída do gerador (Earray), pelo produto da irradiação global incidente no coletor após transposição e a área do módulo. Esses valores também são mostrados no APÊNDICE A. Por outro lado, a eficiência do sistema (EffsysR) foi obtida dividindo-se o valor de energia injetada na rede $\left(E_{G R I D}\right)$, pelo produto da irradiação global incidente no coletor após transposição e a área do módulo. Comparando os valores de eficiência do gerador com os do sistema, nota-se que há uma variação entre 3,5\% a 7\% dentre os casos simulados, e, portanto sem impacto relevante no resultado final de geração de energia. Nos casos em que se adotou o inversor do tipo IG Plus de $4 \mathrm{~kW}$ e 4,6 kW, houve uma variação entre $5 \%$ e $7 \%$.

\subsubsection{Perdas no sistema fotovoltaico}

Por outro lado, a eficiência do gerador fotovoltaico sofre a influência de importantes variáveis, algumas inerentes ao tipo de tecnologia e outras às interferências externas. A Figura 6.2 mostra essas influências em um diagrama de perdas anuais no sistema fotovoltaico, obtida do software PVSYST. 
Figura 6.2 - Diagrama de perdas no sistema fotovoltaico (anual)

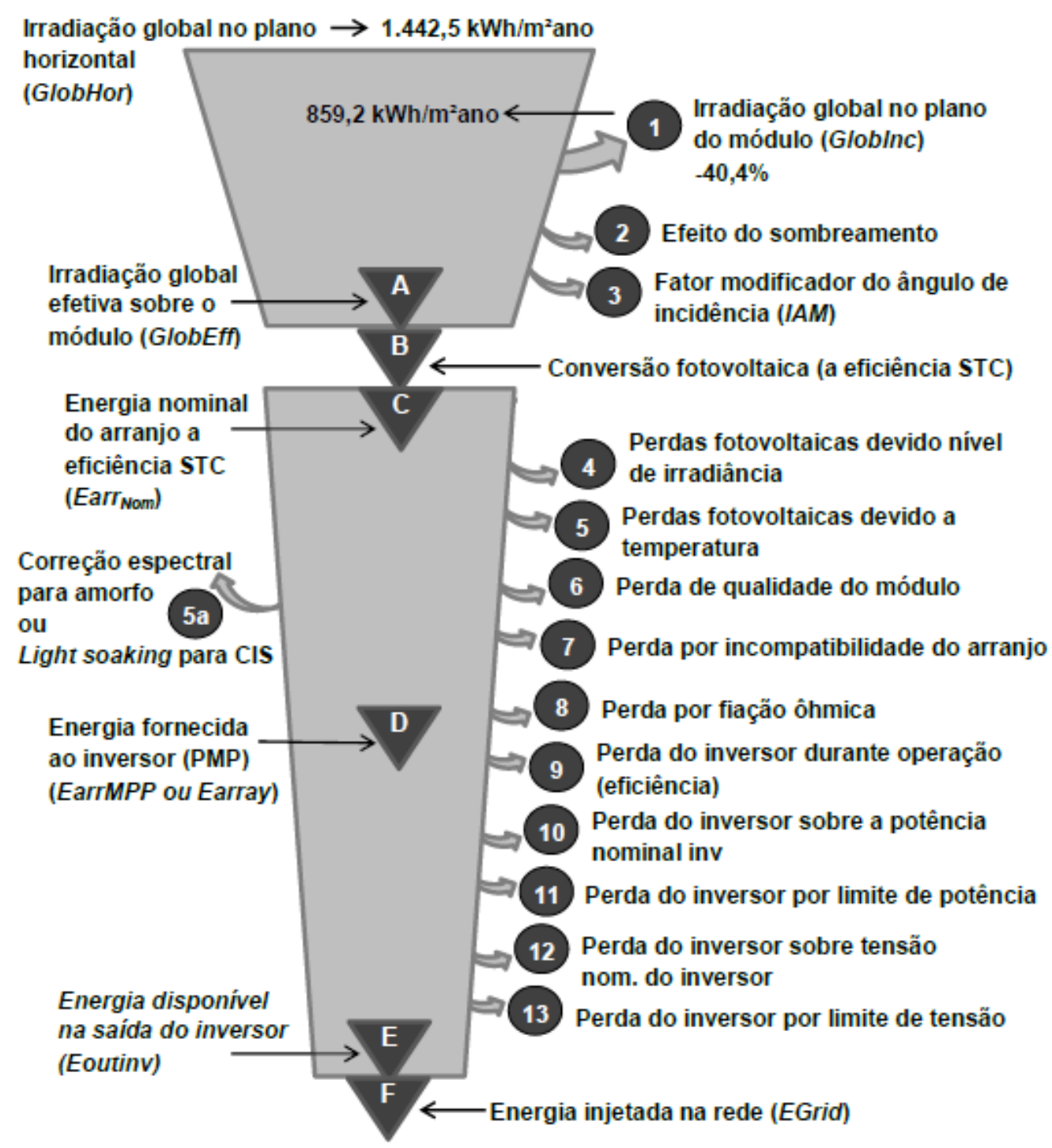

Fonte: Próprio autor com base nas informações do PVSYST. Tradução nossa (2016).

A irradiação global no plano horizontal (GlobHor no PVSYST) no valor de 1.442,5 $\mathrm{kWh} / \mathrm{m}^{2}$ ano corresponde à somatória dos valores mensais obtidos do banco de dados do Meteonorm para a localidade.

Pode-se observar que houve uma perda inicial de 40,4\% da radiação global incidente no plano horizontal, ou irradiação global, em função somente da inclinação dos módulos, resultando em um valor de $859,20 \mathrm{kWh} / \mathrm{m}^{2}$ ano sobre o plano do coletor (GlobInc no PVSYST), cuja inclinação foi de $90^{\circ}$, e após fator de transposição e sem correções óticas. Tanto esse valor como o da perda por efeito de sombreamento, que é de $0,5 \%$, foi comum para todas as simulações efetuadas. 
Portanto, as diferenças entre as tecnologias simuladas puderam ser notadas a partir do fator modificador do ângulo de incidência $(I A M)$, aqui representado por suas perdas. Lembrando que esse fator corresponde à porção reduzida de irradiância que realmente atinge a superfície das células fotovoltaicas, em relação à irradiância sob uma condição de incidência normal, fruto dos efeitos de reflexões e desvios do ângulo de incidência da radiação solar, conforme já explanado anteriormente. Esse efeito varia em função das características do vidro adotado em cada tecnologia e da forma como os elementos do módulo estão montados.

Observa-se pela tabela do APÊNDICE B que esse fator de perda variou entre 3,2\% a 5,1\%, sendo menor para as tecnologias de silício cristalino e maiores para as de filme fino e de vidros fotovoltaicos.

Como resultado parcial obteve-se os valores de irradiação global efetiva (GlobEff no PVSYST) sobre os módulos após perdas óticas (A da Figura 6.2).

Na sequência surge a conversão pelo efeito fotovoltaico (B da Figura 6.2), com base no valor da eficiência do módulo sob condições de teste padrão $\left(S T C^{56}\right)$. Esses valores, conforme mostrados na Tabela 6.2, foram obtidos nas especificações dos catálogos de cada fabricante selecionado e confirmado nos registros do banco de dados do PVSYST, resultando na energia

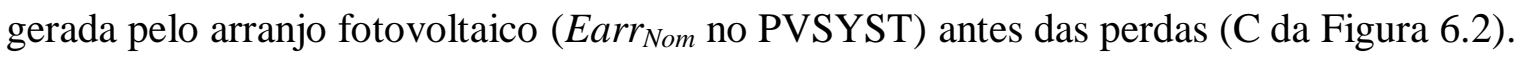

Tabela 6.2 - Eficiências por tecnologia e fabricante adotado

\begin{tabular}{ccc}
\hline Tecnologia de módulo FV & $\begin{array}{c}\text { Efic }_{\text {STC }} \\
\%\end{array}$ & Fabricante \\
\hline Si-Mono (rígido) & 16,54 & Canadian \\
\hline Si-Poli (rígido) & 16,49 & Canadian \\
\hline CaTe (Filme Fino) & 15,97 & First Solar \\
\hline ucSi-aSiH (Filme Fino) & 10,57 & Nexpower \\
\hline CIS (Filme Fino) AV & 11,36 & Avancis \\
\hline CIS (Filme Fino) SF & 13,90 & Solar Frontier \\
\hline CIGS (Filme Fino) & 14,73 & TSMC Solar \\
\hline Vidro FVST (Si-Poli, 36\%) & 8,24 & Vidursolar \\
\hline Vidro FVST (Si-Poli, 16\%) & 10,46 & Vidursolar \\
\hline Vidro FVST (a-Si, 20\%) & 4,82 & Schott Solar \\
\hline Vidro FVST (Si-Mono, 20\%) & 14,83 & SolarWatt \\
\hline
\end{tabular}

Fonte: Próprio autor (2016).

$\overline{56}$ Standard Test Conditions (STC): irradiação de $1.000 \mathrm{~W} / \mathrm{m}^{2}$, massa de ar (AM) de 1,5 e temperatura de célula de $25^{\circ} \mathrm{C}$. 
Em que:

Efic $_{\text {STC: }}$ : eficiência do módulo sob condições de teste padrão (STC);

FVST: fotovoltaico semitransparente.

Nota-se que as menores eficiências nominais apresentadas são aquelas relacionadas às tecnologias de vidros fotovoltaicos e de filmes finos, sendo que dentro desses grupos a aplicação de silício amorfo reduziu significativamente o seu rendimento.

Essa energia elétrica em corrente contínua alimenta o inversor (D da Figura 6.2) após descontar as perdas na interface $\mathrm{CC}$, as quais são compostas pelas perdas inerentes ao processo fotovoltaico: pela variação do nível de irradiância, temperatura e pela própria qualidade do módulo. Esse último parâmetro (item 6 da Figura 6.2) reflete a confiança de desempenho real em relação à especificação do fabricante, com base na faixa de tolerância estabelecida para o valor de potência em relação ao nominal do produto.

A maioria dos valores variou na faixa de $-2,5 \% \mathrm{a}+1,3 \%$, tendo um caso mais crítico relativo ao vidro fotovoltaico do fabricante SolarWatt apresentando um desvio de $-5,0 \%$, conforme pode ser visto no APÊNDICE B.

As tecnologias com base no silício apresentam um efeito de degradação induzida pela luz, (LID) chamada de efeito Staebler-Wronski (SW), causando uma redução em seu desempenho elétrico. Essa redução acontece nas primeiras horas de operação do módulo de silício cristalino em torno de $2 \%$ (o que foi adotado nas simulações). No caso do silício amorfo, isto ocorre nos primeiros meses de aplicação, normalmente especificada pelos fabricantes na ordem de $15 \%$, podendo atingir 35\%. Após o período de duração desse efeito, estimado na ordem de três a cinco meses, a eficiência estabiliza em valores próximos ao nominal informado nos catálogos dos fabricantes (RÜTHER et al, 2003).

Para efeito desta simulação, esse aspecto não foi considerado para o silício amorfo. No entanto, para essa tecnologia foi considerada uma correção espectral de $+1 \%$.

Tanto os módulos formados com células de telureto de cadmio quanto os filmes finos de CIGS/CIS apresentam o efeito chamado de light soaking, ou imersão de luz, cuja característica é o aumento de sua eficiência após um tempo de exposição à radiação solar. Esse efeito tem uma influência relevante no dimensionamento do sistema fotovoltaico, pois a tensão de circuito aberto do módulo pode aumentar em até $6 \%$ após algumas centenas de horas de exposição à irradiação solar (DEL CUETO; VON ROEDEM, 2006). Esse efeito foi considerado nas simulações. 
A perda em função da temperatura do arranjo fotovoltaico (item 5 da Figura 6.2) é calculada com base em um balanço térmico que envolve o fator de perda de calor (U), como já citado anteriormente. Esse fator foi estabelecido em função da forma como o arranjo está disposto na fachada do edifício, permitindo a circulação de ar livre na totalidade das faces dos módulos ou parcialmente. Essa variável, além daquela devido à variação da irradiância, causou perdas significativas em todos os casos simulados, conforme mostrado na Figura 6.3.

\section{Figura 6.3- Perdas devido à temperatura e à variação de irradiância}

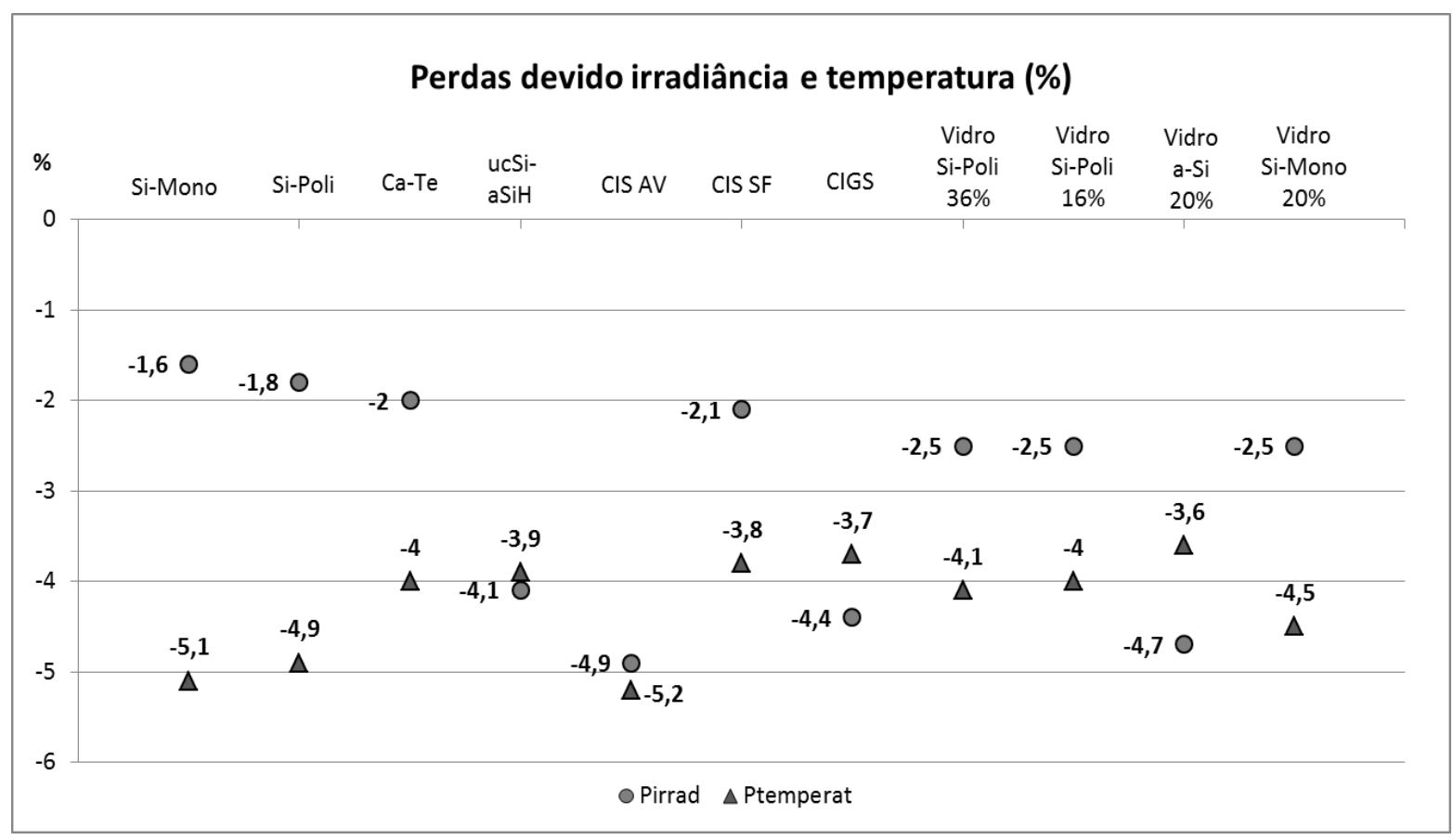

Fonte: Próprio autor com base nos resultados do PVSYST (2016).

Em que:

Ptemperat: perda em função da temperatura do arranjo fotovoltaico;

Pirrad: perda em função da variação de irradiância.

Nota-se que as menores perdas relacionadas à temperatura dos módulos correspondem às tecnologias que utilizam o silício amorfo $(3,6 \%$ a 3,9\%) e aquelas com base em filmes finos (3,8\% a 4,0\%) com exceção do CIS do fabricante Avancis (5,2\%). As tecnologias com base no silício cristalino foram as que apresentaram maiores perdas nesse quesito $(4,0 \%$ a 5,1\%). Já as perdas devido à variação do nível de irradiância (item 4 da Figura 6.2) se concentram em uma faixa menor, sendo o silício cristalino o que apresenta menor perda tanto em módulos rígidos como em vidros fotovoltaicos $(1,6 \%$ a $2,5 \%)$. Por outro lado, as tecnologias de filmes finos e de silício amorfo apresentam valores entre $2,0 \%$ a $4,9 \%$. 
Outras perdas são relativas ao arranjo, às instalações elétricas no percurso entre os módulos e a conexão no inversor, e ao ajuste do conjunto na busca do Ponto de Máxima Potência (PMP). A perda por incompatibilidade do arranjo está relacionada com o fato de seus módulos fotovoltaicos não apresentarem exatamente as mesmas características I/V (curva do "joelho"). A corrente elétrica de uma string (série de módulos) do arranjo fotovoltaico é limitada pelo desempenho do módulo que apresente as piores condições. Quanto mais heterogeneo for o conjunto, maior será a influência dessas perdas no resultado.

A energia disponível na saída do inversor (Eoutinv no PVSYST) pode ser a mesma injetada à rede (EGrid no PVSYST) desde que as perdas dos circuitos elétricos de sua interface sejam irrelevantes. Essa energia em corrente alternada é o produto da conversão CC-CA, sendo que suas perdas são exclusivamente dependentes das características construtivas e técnicas do inversor.

No APÊNDICE B são apresentados os dados mais completos e detalhes dessas perdas.

\subsubsection{Resultados de energia gerada}

As simulações apresentaram comportamentos e resultados diferentes para cada tecnologia fotovoltaica, conforme valores mostrados no APÊNDICE C e na Tabela 6.3.

Tabela 6.3 - Resultados das simulações - Energias anuais geradas pelo sistema fotovoltaico

\begin{tabular}{|c|c|c|c|c|c|c|c|}
\hline \multirow[b]{2}{*}{ Tecnologia de módulo FV } & \multicolumn{7}{|c|}{ Energias geradas pelo sistema fotovoltaico (anual) } \\
\hline & $\begin{array}{c}\begin{array}{c}\text { A } \\
\text { (GlobEff) } \\
\mathrm{kWh} / \mathrm{m}^{2} \mathrm{ano}\end{array} \\
\end{array}$ & $\begin{array}{c}\text { Área } \\
\text { arranjo } \\
\mathrm{m}^{2} \\
\end{array}$ & $\begin{array}{c}\text { B } \\
\text { (STC) } \\
\% \\
\end{array}$ & $\begin{array}{c}\text { C } \\
\left(\text { Earr }_{\text {nom }}\right) \\
\text { MWh/ano }\end{array}$ & $\begin{array}{c}\text { D } \\
\text { (Earray) } \\
\text { MWh/ano }\end{array}$ & $\begin{array}{c}\mathbf{E} \\
\text { (Eout }_{\text {inv }} \text { ) } \\
\text { MWh/ano }\end{array}$ & $\begin{array}{c}\mathbf{F} \\
\left(\mathbf{E}_{\mathbf{G R I D}}\right) \\
\text { MWh/ano }\end{array}$ \\
\hline Si-Mono (rígido) & 827,4 & 203,0 & 16,54 & 27,72 & 25,60 & 24,71 & 24,71 \\
\hline Si-Poli (rígido) & 827,4 & 203,0 & 16,49 & 27,62 & 25,58 & 24,69 & 24,69 \\
\hline CaTe (Filme Fino) & 814,5 & 202,0 & 15,97 & 26,22 & 23,72 & 22,92 & 22,92 \\
\hline ucSi-aSiH (Filme Fino) & 811,1 & 203,0 & 10,57 & 17,43 & 16,11 & 15,00 & 15,00 \\
\hline CIS (Filme Fino) AV & 811,1 & 190,0 & 11,36 & 17,50 & 15,75 & 15,18 & 15,18 \\
\hline CIS (Filme Fino) SF & 811,1 & 196,0 & 13,90 & 22,15 & 21,13 & 20,36 & 20,36 \\
\hline CIGS (Filme Fino) & 811,1 & 215,0 & 14,73 & 25,70 & 23,33 & 21,71 & 21,71 \\
\hline Vidro FVST (Si-Poli, 36\%) & 811,1 & 197,0 & 8,24 & 13,19 & 11,84 & 11,02 & 11,02 \\
\hline Vidro FVST (Si-Poli, 16\%) & 811,1 & 203,0 & 10,46 & 17,19 & 15,45 & 14,39 & 14,39 \\
\hline Vidro FVST (a-Si, 20\%) & 811,1 & 211,0 & 4,82 & 8,25 & 7,16 & 6,77 & 6,77 \\
\hline Vidro FVST (Si-Mono, 20\%) & 811,1 & 227,0 & 14,83 & 27,25 & 25,16 & 24,26 & 24,26 \\
\hline
\end{tabular}

Fonte: Próprio autor (2017). 
Em que:

A: irradiação global efetiva sobre o módulo (GlobEff);

B: eficiência de conversão fotovoltaica sob condições STC;

C; energia nominal do arranjo fotovoltaico a condições STC (EarrNom);

D: energia fornecida ao inversor PMP (EarrMPP ou Earray);

E; energia disponível na saída do inversor (Eoutinv);

F; energia injetada na rede (EGrid);

Irradiação global no plano horizontal (GlobHor): 1.442,5 kWh/m²ano;

Irradiação global no plano do módulo (GlobInc): 859,2 KWh/m²ano.

A Tabela 6.3 resume os pontos mais importantes do sistema fotovoltaico para análise de energia gerada, considerando as perdas comentadas na subseção anterior. Essas etapas do sistema fotovoltaico correspondem às nomenclaturas citadas na Figura 6.2.

Nota-se que cada tecnologia simulada apresentou um valor diferente de energia anual injetada à rede elétrica $\left(E_{G R I D}\right)$, em função de suas características técnicas, forma de instalação do arranjo fotovoltaico e de sua área. No entanto, essas grandezas são compostas por valores absolutos, o que não permite uma comparação confiável de seu desempenho.

Assim, foram estabelecidos indicadores de produtividade com base na densidade de energia gerada e de potência por unidade de área ocupada pelo respectivo arranjo fotovoltaico, conforme é mostrado na Tabela 6.4.

Tabela 6.4- Resultados das simulações - Densidade de energia anual gerada (Earray) e de potência por área ocupada pelo arranjo fotovoltaico

\begin{tabular}{|c|c|c|c|c|c|}
\hline \multirow{3}{*}{ Tecnologia de módulo FV } & \multicolumn{2}{|c|}{$\begin{array}{c}\text { Densidade de Energia } \\
\text { Gerada } \\
\end{array}$} & \multicolumn{2}{|c|}{$\begin{array}{c}\text { Densidade de Potencia do } \\
\text { gerador FV }\end{array}$} & \multirow{2}{*}{$\begin{array}{c}\text { Relação de } \\
\text { Energia } \\
\text { Gerada e } \\
\text { Potencia }\end{array}$} \\
\hline & $\begin{array}{c}\text { por unidade } \\
\text { de área de } \\
\text { módulos }\end{array}$ & $\begin{array}{c}\text { por unidade } \\
\text { de área de } \\
\text { celulas }\end{array}$ & $\begin{array}{c}\text { por unidade } \\
\text { de área de } \\
\text { módulos }\end{array}$ & $\begin{array}{c}\text { por unidade } \\
\text { de áre a de } \\
\text { celulas }\end{array}$ & \\
\hline & $\mathrm{kWhano} / \mathrm{m}^{2} \mathrm{mod}$ & $\mathrm{kWhano} / \mathrm{m}^{2} \mathrm{cel}$ & $\mathrm{Wp} / \mathrm{m}^{2} \bmod$ & $\mathrm{Wp} / \mathrm{m}^{2} \mathrm{cel}$ & kWhano/kWp \\
\hline Si-Mono (rígido) & 126,1 & 141,5 & 164,5 & 184,5 & 766,6 \\
\hline Si-Poli (rígido) & 126,0 & 139,0 & 164,5 & 181,5 & 766,0 \\
\hline CaTe (Filme Fino) & 117,4 & 125,5 & 159,4 & 170,4 & 736,7 \\
\hline ucSi-aSiH (Filme Fino) & 79,3 & 83,9 & 104,0 & 110,0 & 762,6 \\
\hline CIS (Filme Fino) AV & 82,9 & 82,9 & 113,7 & 113,7 & 729,1 \\
\hline CIS (Filme Fino) SF & 107,8 & 107,8 & 138,8 & 138,8 & 776,8 \\
\hline CIGS (Filme Fino) & 108,5 & 119,6 & 147,4 & 162,6 & 735,9 \\
\hline Vidro FVST (Si-Poli, 36\%) & 60,1 & 60,1 & 82,2 & 82,2 & 730,9 \\
\hline Vidro FVST (Si-Poli, 16\%) & 76,1 & 76,1 & 104,0 & 104,0 & 731,7 \\
\hline Vidro FVST (a-Si, 20\%) & 34,0 & 34,0 & 47,8 & 47,8 & 710,7 \\
\hline Vidro FVST (Si-Mono, 20\%) & 110,8 & 110,8 & 148,0 & 148,0 & 748,8 \\
\hline
\end{tabular}

Fonte: Próprio autor (2017). 
Em que:

Densidade de Energia Gerada: Energia anual gerada pelo gerador fotovoltaico em corrente contínua (Earray) por unidade de área do arranjo de módulos/área de células;

Densidade de Potência do gerador FV: Potência nominal do gerador fotovoltaico por unidade de área do arranjo de módulos/área de células;

Relação de Energia Gerada e Potência: Energia anual gerada pelo gerador fotovoltaico em corrente contínua por unidade de potência nominal do arranjo fotovoltaico.

A Tabela 6.4 compara as diversas tecnologias simuladas através dos valores de densidade de energia gerada em corrente contínua por unidade de área do arranjo dos módulos ou do conjunto de células fotovoltaicas. A energia gerada nesse ponto já considera as perdas por transposição, óticas e de eficiência, além daquelas relacionadas com o nível de irradiância, temperatura e qualidade dos módulos fotovoltaicos.

A relevância dessa análise foi justificada pelo fato de possibilitar uma análise do desempenho das tecnologias fotovoltaicas antes mesmo de entrar no mérito das perdas do inversor e dos elementos do circuito de corrente alternada, evitando dessa forma distorções nas conclusões desta pesquisa.

A Figura 6.4 faz uma comparação dos resultados de densidade de energia anual gerada por unidade de área do arranjo fotovoltaico, obtida para cada tecnologia simulada. 
Figura 6.4 - Pareto da Densidade de Energia anual gerada por tecnologia

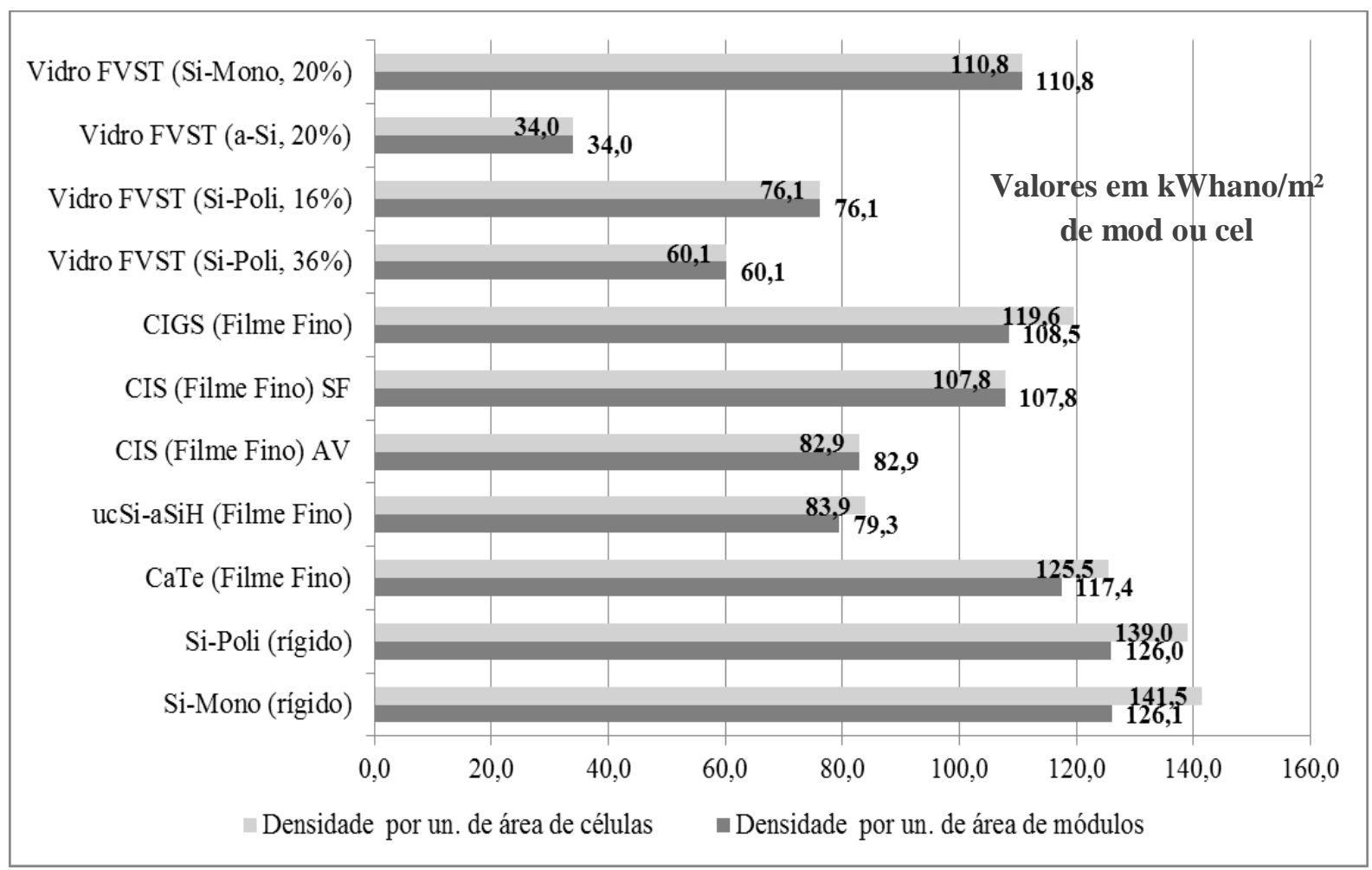

Fonte: Próprio autor (2017).

Observa-se no pareto que as tecnologias de módulos rígidos e de filmes finos, caso do telureto de cadmio, do CIGS e da junção Tandem em silício, apresentaram uma diferença entre os valores de densidade por unidade de área de módulos e por unidade de células. Esse fato foi decorrente principalmente pela forma com que os módulos foram fabricados: com esquadrias ou molduras em suas bordas ou com áreas improdutivas energeticamente. Essas porções variaram entre $5 \%$ a $11 \%$ da área total do módulo.

Os resultados detalhados por tecnologia são apresentados no APÊNDICE E.

Considerando que o objetivo deste trabalho é a comparação de desempenho técnico de tecnologias disponibilizadas no mercado, foi determinado que o parâmetro ideal para o avanço desta pesquisa seria a densidade de energia gerada por unidade de área de módulos, pois esses são os produtos comercializados para o mercado da construção civil, e não as células.

Assim, foram comparados os resultados tomando como referência a tecnologia que apresentou o maior desempenho dentre as que foram simuladas, sendo as demais inseridas em um pareto, na proporção de sua densidade de energia gerada em relação a essa referência. A Figura 6.5 mostra esse comparativo. 
Figura 6.5 - Comparativo da Densidade de Energia anual gerada por unidade de área de módulos

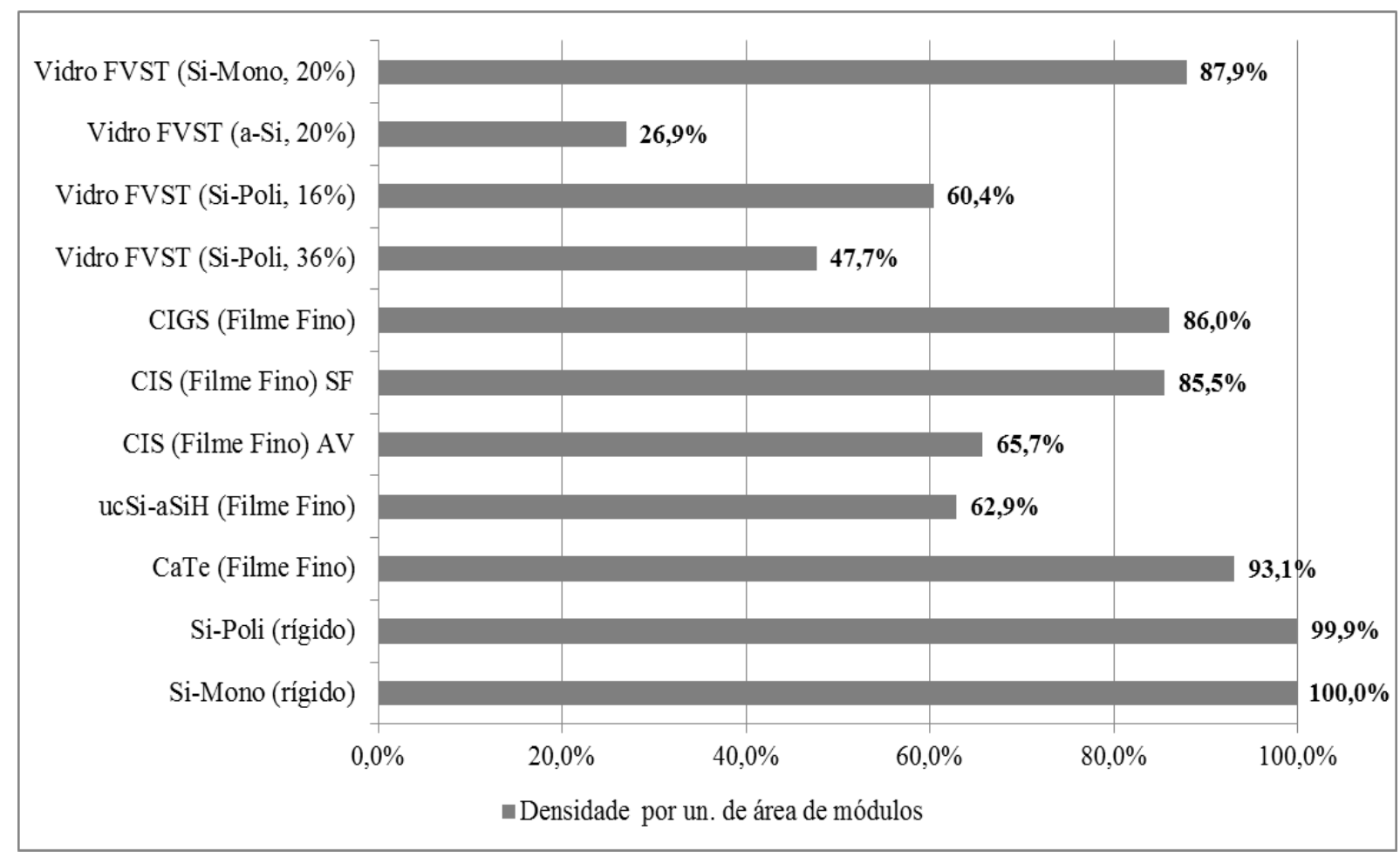

Fonte: Próprio autor (2017).

A Figura 6.5 mostra que a tecnologia de maior desempenho técnico foi a de silício cristalino, mono ou policristalino, na forma de painéis rígidos, evidenciando o motivo pelo qual é a mais comercializada mundialmente até hoje.

A tecnologia que mais se aproximou dela foi a de telureto de cadmio, apresentando um desempenho aproximadamente $7 \%$ menor, seguido pelos filmes finos CIS e CIGS com comportamento inferior na faixa de $14 \%$ a $15 \%$ em relação a do silício cristalino. O produto CIS da Avancis teve um comportamento bem abaixo (34\% menor) comparado ao da Solar Frontier (SF).

Os piores desempenhos ficaram por conta das tecnologias de filme fino com junção Tandem em silício (provavelmente devido à composição com silício amorfo), com uma queda de 37\%, e a de vidros fotovoltaicos semitransparentes (FVST) utilizando o silício amorfo ou o silício policristalino. A tecnologia de silício amorfo aplicado no vidro FVST apresentou o menor resultado dentre todos os casos simulados, com 73\% de redução em seu desempenho.

Os vidros FVST com base no silício policristalino, apresentaram resultados na faixa entre $40 \%$ a $52 \%$ inferiores em relação aos dos painéis rígidos de silício cristalino. No entanto, a 
adoção do silício monocristalino no vidro FVST da SolarWatt propiciou uma elevação de seu desempenho, resultando em uma diferença de apenas $12 \%$ em relação à mesma referência.

Observa-se ainda que houve uma queda acentuada de desempenho entre os casos do vidro FVST que adotou o silício monocristalino e aquele com silício amorfo, apresentando 69\% de diferença, mesmo que ambos tenham o mesmo grau de semitransparência. Já os vidros FVST com base no silício policristalino mostraram resultados intermediários de desempenho: entre $31 \%$ a $45 \%$ menores em relação ao do vidro FVST com silício monocristalino, que se pesem seus diferentes níveis de semitransparência.

\subsubsection{Comportamento da energia gerada em função da resposta espectral}

Além de outras perdas, certas características dos materiais utilizados nas células fotovoltaicas limitam sua eficiência na conversão da luz solar incidente sobre ela: a resistência natural do material semicondutor, a temperatura de operação, índices de absorção ótica a radiação solar do material, a resistência elétrica de suas conexões e a resposta no espectro de frequência.

A resistência natural ao fluxo de elétrons em uma célula diminui a eficiência da célula. Essas perdas ocorrem predominantemente em três pontos: no material solar primário, na fina camada superior e na interface entre a célula e os contatos elétricos (US DEPARTMENT OF ENERGY $Y^{57}$, 2013).

Por regra, as células perdem eficiência com o aumento da temperatura de operação, seguindo as propriedades de seus materiais. Portanto é necessário ter um arranjo tal que permita a dissipação do calor, seja por efeito natural ou forçado.

Segundo o US Department of Energy (2013), a eficiência da célula aumenta com a redução da quantidade de radiação refletida em sua superfície, como por exemplo, o silício não tratado que reflete mais do que $30 \%$ da luz incidente. A aplicação de revestimentos antirreflexos na face superior da célula proporciona uma maior absorção de radiação, sendo geralmente dispostos em várias camadas para abranger um intervalo mais amplo de comprimentos de onda. Outro processo usual é a texturização da superfície superior da célula, fazendo com que a radiação refletida incida em uma segunda superfície antes de deixar a célula, aumentando assim sua probabilidade de absorção ótica. Um exemplo disso, de forma mais potencializada, é a texturização em forma de pirâmides, o que faz com que a radiação incidente seja direcionada a uma segunda superfície polida, porém não tratada.

\footnotetext{
${ }^{57}$ Departamento de Energia dos EUA que trata da segurança, ciência e tecnologia do país para assuntos energéticos, ambientais e nucleares.
} 
Quanto maior o contato elétrico menor será sua resistência elétrica. No entanto, deve-se encontrar um tamanho de contato que reduza ao mesmo tempo os efeitos de sombreamento sobre a célula fotovoltaica. $\mathrm{O}$ modelo com contato na face traseira da superfície da célula tem um processo mais simples do que o de topo, por possuir apenas uma camada de metal, além do que aumenta a resistência à deterioração provocada por alterações na temperatura ou humidade. Outro modelo também adotado é um arranjo de contatos dispostos em torno da superfície da célula, ou ainda por deposição de uma camada fina de um óxido condutor transparente em toda a célula, como em alguns filmes finos.

A luz é um fluxo de fótons, sendo que cada fóton contém uma energia e é associado com um comprimento de onda. Quando a luz atinge a superfície de uma célula solar, alguns fótons são refletidos enquanto outros passam através do material. Desses, alguns são absorvidos, porém com energia suficiente apenas para gerar calor, e outros têm energia capaz de separar os elétrons de suas ligações atômicas e assim produzir a corrente elétrica. Esses últimos dispõem de uma quantidade de energia capaz de liberar um elétron de seu vínculo (bandgap ${ }^{58}$ ), apresentando diferentes intervalos de valores em função do tipo do material semicondutor aplicado e de sua temperatura de operação. O bandgap do material mais difundido na fabricação de células fotovoltaicas (silício) encontra-se na faixa de 1,2 elétron-Volt $(\mathrm{eV})$, sendo que sua sensibilidade espectral está em um patamar acima de 1,2 $\mu \mathrm{m}$ de comprimento de onda (BAUMGAERTNER $\left.{ }^{59}, 2013\right)$.

A eficiência de conversão é uma medida que caracteriza o desempenho da célula fotovoltaica, e é mensurada pela razão entre a quantidade de cargas coletadas por uma célula fotovoltaica e a quantidade de fótons incidentes sobre a mesma, ou seja, é a resposta de uma célula solar para os vários comprimentos de onda no espectro de radiação incidente. Portanto, pode-se afirmar que a eficiência de conversão para fótons cuja energia esteja abaixo do bandgap de certo material semicondutor, é zero.

Um fato importante é que quanto menor o comprimento de onda, ou maior a frequência, maior será a energia do fóton. O efeito fotovoltaico tem um comportamento baseado principalmente nessa energia. Por outro lado, grande parte dos fótons de onda curta, que contêm muita energia, pode não ser absorvida.

\footnotetext{
${ }^{58}$ Bandgap: quantidade mínima de energia capaz de separar os elétrons de suas ligações atômicas e assim produzir a corrente elétrica, para certo tipo de material semicondutor, expressa em eletron-Volt.

${ }^{59}$ CEO e fundador da Green Rhino Energy Ltd, localizada na Inglaterra. Especialista em fotovoltaica, possui MBA pela London Business School, MPhil em Energia Renovável pela Universidade de Loughborough e Mestrado em Engenharia Elétrica pela Universidade de Stuttgart.
} 
Segundo o US Department of Energy (2013), 25\% da energia incidente nas células fotovoltaicas tradicionais (silício) é composta por fótons com energia inferior ao bandgap do material, e, portanto não sendo absorvida. Por outro lado, os fótons com energia acima do bandgap também não são aproveitados, sendo reemitidos em forma de calor ou de luz e proporcionando uma perda adicional em torno de 30\%. Portanto, o índice de ineficiência dos materiais das células relativo à resposta no espectro de frequência é na ordem de $55 \%$ da energia incidente.

Devido às sensibilidades espectrais, a taxa de resposta para conversão fotovoltaica dos materiais semicondutores é dependente principalmente do comprimento de onda da luz incidente. A Figura 6.6 mostra alguns exemplos de sensibilidade espectral em função do material que compõe as células fotovoltaicas.

Figura 6.6- Sensibilidade espectral dos materiais e do olho humano

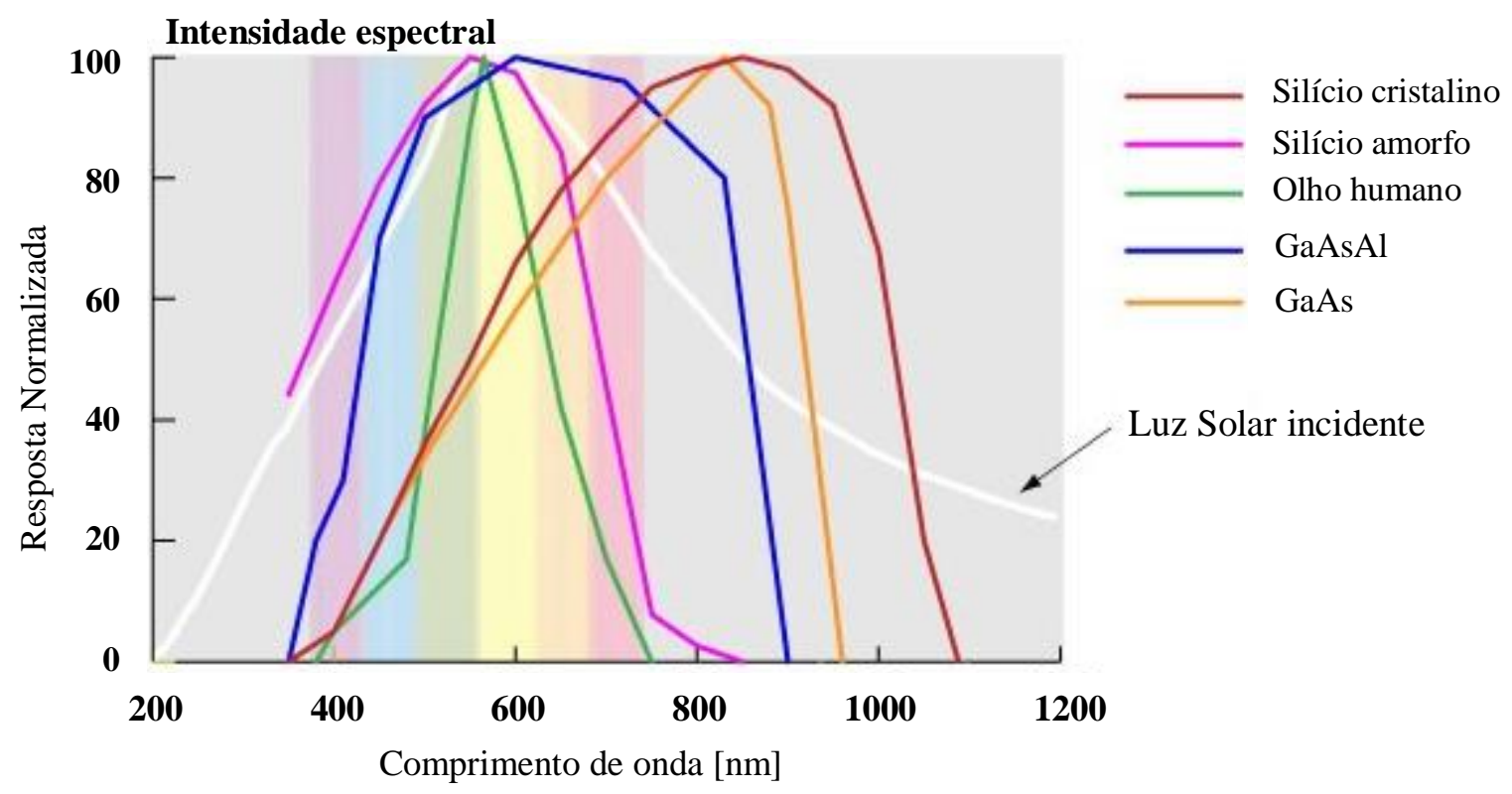

Fonte: Adaptado de Baumgaertner (2013). Tradução nossa.

O silício cristalino possui uma resposta espectral em um intervalo maior do que a do olho humano, porém em uma faixa deslocada da luz visível, e, portanto menos eficiente na conversão do espectro visível, região que corresponde a aproximadamente $48 \%$ da energia proveniente do Sol. Já o silício amorfo bem como o composto de arseneto de gálio e alumínio (GaAsAl), respondem em intervalos em que a sensibilidade espectral é melhor adaptada à luz solar incidente, aumentando assim a eficiência da célula, porém dentro dos limites de conversão estabelecidos pelo próprio material empregado. 
A captura de um espectro mais amplo por uma célula fotovoltaica pode ser obtida pelo uso de dois materiais distintos dispostos em configuração tandem ou multi-junção.

Como já citado, o efeito fotovoltaico tem seu comportamento baseado principalmente na energia dos fótons incidentes, e que estejam dentro da faixa de resposta do espectro de frequência da tecnologia de célula adotada. Porém o efeito é proveniente não somente da incidência de radiação direta, mas também da parcela de radiação difusa.

A radiação que atinge a superfície terrestre é atenuada pelas camadas da atmosfera e é formada por dois componentes: a radiação direta e a radiação difusa.

Enquanto que a radiação direta é a parcela que penetra diretamente na superfície da Terra sem nenhuma interferência da atmosfera, a radiação difusa é um resultado da absorção e dispersão causada pelos gases e aerossóis da atmosfera ou de sua reflexão de volta para a Terra. A radiação difusa é a responsável pela claridade do céu durante o dia, sendo notada com menor influência em dias com céu limpo e com maior evidência quando há nuvens que são importantes elementos refletores.

Entende-se, portanto, que o comportamento da eficiência na conversão de energia das tecnologias de células fotovoltaicas deva variar no decorrer do ano em função, além das variáveis de geometria solar, da proporção dos dois componentes da radiação global incidente em sua superfície, pois cada tecnologia apresenta a sua respectiva resposta no espectro de frequência. Para tanto, outras variáveis como temperatura, índice de sujidade e ciclo de vida devem ser equalizadas.

Comparando-se os casos simulados neste trabalho pôde-se obter uma noção da influência da radiação difusa no comportamento de cada tecnologia fotovoltaica, considerando as condições impostas nas simulações. Analisando sob o ponto de vista dos resultados obtidos na saída do gerador fotovoltaico (em corrente contínua), este estudo contou com alguns parâmetros fixos para cada tecnologia, e, portanto, sem influência em sua eficiência durante o ano, tais como: índice de sujidade, degradação física zero, área do arranjo fotovoltaico, resistência natural e índice de absorção do material semicondutor e resistência elétrica das conexões. Outras variáveis como: localidade da instalação, condições ambientais e posicionamento do arranjo de módulos foram comuns a todas as simulações.

Assim, pôde-se avaliar o comportamento de cada tecnologia fotovoltaica simulada em função de sua respectiva resposta espectral, com base em seus desempenhos em cada estação do ano, cujos resultados são apresentados no APÊNDICE F e na Tabela 6.5 em termos de participação no total gerado anualmente. Objetivando facilitar a análise os casos simulados foram agrupados por semelhança tecnológica. 
Tabela 6.5 - Participação (\%) da energia gerada em corrente contínua por estação em relação ao gerado no ano

\begin{tabular}{ccccccc}
\hline $\begin{array}{c}\text { Estações } \\
\text { do ano }\end{array}$ & $\begin{array}{c}\text { Grupo do } \\
\text { silício } \\
\text { cristalino }\end{array}$ & $\begin{array}{c}\text { Grupo } \\
\text { do silício } \\
\text { amorfo }\end{array}$ & $\begin{array}{c}\text { Grupo } \\
\text { do CaTe }\end{array}$ & $\begin{array}{c}\text { Grupo dos } \\
\text { CIS/CIGS }\end{array}$ & $\begin{array}{c}\text { Grupo dos } \\
\text { vidros } \\
\text { FVST }\end{array}$ & $\begin{array}{c}\text { Grupo do } \\
\text { Tandem }\end{array}$ \\
\hline Verão & $17,2 \%$ & $17,4 \%$ & $17,1 \%$ & $16,9 \%$ & $17,3 \%$ & $17,5 \%$ \\
\hline Outono & $31,5 \%$ & $31,4 \%$ & $31,6 \%$ & $31,8 \%$ & $31,5 \%$ & $31,3 \%$ \\
\hline Inverno & $34,1 \%$ & $33,9 \%$ & $34,3 \%$ & $34,5 \%$ & $34,1 \%$ & $33,9 \%$ \\
\hline Primavera & $17,1 \%$ & $17,3 \%$ & $17,0 \%$ & $16,8 \%$ & $17,1 \%$ & $17,4 \%$ \\
\hline Ano & $100,0 \%$ & $100,0 \%$ & $100,0 \%$ & $100,0 \%$ & $100,0 \%$ & $100,0 \%$ \\
\hline
\end{tabular}

Fonte: Próprio autor (2017).

Em que:

Grupo do silício cristalino: silício mono e policristalino (rígidos), Vidro FVST Si-Poli 36\% e 16\%, Vidro FVST Si-Mono $20 \%$.

Grupo do silício amorfo: Tandem ucSi-aSiH (Filme Fino), Vidro FVST a-Si 20\%.

Grupo do CaTe: CaTe (Filme Fino)

Grupo dos CIS/CIGS: CIS AV, CIS SF, CIGS (Filmes Finos)

Grupo dos vidros fotovoltaicos semitransparentes (FVST): Vidro FVST Si-Poli 36\% e 16\%, Vidro FVST Si-Mono 20\%, Vidro FVST a-Si $20 \%$.

Grupo do Tandem: ucSi-aSiH (Filme Fino).

Observa-se na Tabela 6.5, de uma forma global, que a estação em que ocorre a maior geração de energia é o inverno em função da inclinação $\left(90^{\circ}\right)$ e da orientação (Norte) dos módulos fotovoltaicos.

Apesar dos resultados positivamente relevantes no que diz respeito à densidade de energia gerada por unidade de área, as tecnologias CIS e CIGS (filmes finos), apresentou uma distribuição de energia anual gerada nas estações do ano com uma maior variação dentre os grupos de tecnologia simulados, conforme mostrado na Tabela 6.5. Seu desempenho no verão foi o menor dentre os grupos, enquanto na estação de inverno se destacou favoravelmente, indicando como a tecnologia mais adequada, dentro do universo simulado, no que tange ao aproveitamento da radiação difusa.

Na sequência surgiu o grupo do telureto de cadmio com comportamento semelhante. 
As demais tecnologias simuladas apresentaram valores com variação menor da energia gerada entre as estações.

Maiores detalhes do comportamento de cada tecnologia são mostrados no APÊNDICE D.

Para uma melhor visualização dessas variações dentro de cada tecnologia, adotou-se como base comparativa relevante a parcela de variação da densidade de energia gerada por unidade de área do arranjo fotovoltaico (módulos) resultante na estação de inverno em relação ao do verão. O Apêndice F e a Figura 6.7 apresentam estas variações em forma gráfica.

Figura 6.7 - Parcela de variação da densidade de energia gerada por unidade de área de módulos fotovoltaicos no inverno em relação ao verão

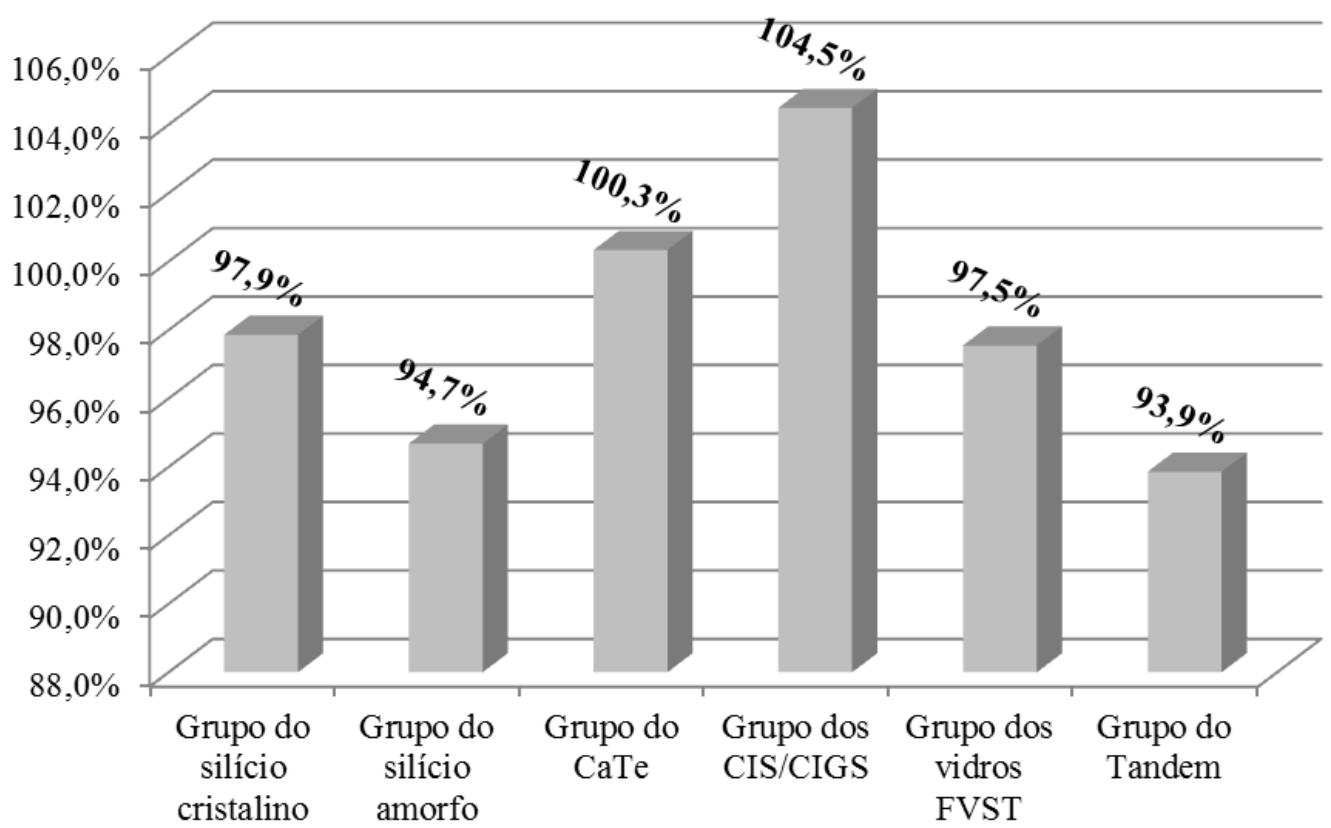

Fonte: Próprio autor (2017).

A Figura 6.7 mostra uma parcela adicional de densidade de energia gerada por metro quadrado do arranjo no inverno, na proporção de 104,5\% além do montante gerado na época de verão para o grupo de tecnologia CIS/CIGS. Valor pouco maior (4\% de diferença) que a tecnologia de telureto de cadmio, mas consideravelmente distante das outras tecnologias simuladas: diferenças na faixa de $7 \%$ a $10 \%$.

Os resultados indicaram as tecnologias tecnicamente mais adequadas, dentre as simuladas, para os casos em que haja necessidade de maior aproveitamento da radiação difusa. 


\section{2 Índice de degradação das células}

A estimativa de geração de energia elétrica ao longo do ciclo de vida de um sistema fotovoltaico necessita como base os respectivos índices de degradação de seus diversos componentes, principalmente dos módulos, dos inversores e da instalação.

Uma pesquisa desenvolvida por Jordan e Kurtz (2011), mostra os resultados revisados abrangendo diversas publicações relativas ao tema ao longo dos últimos 40 anos. Com foco na degradação de módulos e de sistemas, a pesquisa é composta por duas seções básicas: publicações antes e depois do ano 2000, pois somente após esse ano as aplicações no mercado mundial de sistemas com filmes finos se tornaram mais expressivas.

Vale esclarecer que os índices de degradação têm relação com a redução na geração de energia elétrica, sendo que a parcela denominada de instalação engloba todos os elementos do sistema fotovoltaico inclusive os módulos, apesar de possuir também seu índice mostrado à parte, conforme pode ser visualizado na Tabela 6.6 em valores médios a partir do ano 2000.

Tabela 6.6 - Índices de degradação de células fotovoltaicas

\begin{tabular}{cc}
\hline Tecnologia fotovoltaica & $\begin{array}{c}\text { Índice de degradação de } \\
\text { módulos (\% ao ano) }\end{array}$ \\
\hline $\mathrm{Si}-\mathrm{Mono}$ & 0,4 \\
\hline $\mathrm{Si}-\mathrm{Poli}$ & 0,58 \\
\hline $\mathrm{a}-\mathrm{Si}$ & 1,16 \\
\hline $\mathrm{CdTe}$ & 0,65 \\
\hline $\mathrm{CI}(\mathrm{G}) \mathrm{S}$ & 1,31 \\
\hline
\end{tabular}

Fonte: Rampinelli et al (2012).

Os índices de degradação mostrados na tabela acima são valores médios para cada uma das tecnologias fotovoltaicas, calculadas a partir de estudos publicados entre os anos 2000 e 2011 (RAMPINELLI et al, 2012).

Nota-se que o silício cristalino é a tecnologia que apresenta o menor índice de degradação, basicamente em função de sua maturidade tecnológica. Ao contrário, o módulo CIGS possui maior índice de degradação por ser uma tecnologia mais recente.

Diferente dos indicadores de degradação dos módulos, os índices relativos à instalação podem facilmente sofrer alterações em função das diversas variáveis que a compõem. 


\subsection{Eficiência e degradação das tecnologias fotovoltaicas}

Com base nos dados de densidade de energia gerada por unidade de área do arranjo de módulos fotovoltaicos (APÊNDICE E) e de seu respectivo índice de degradação (Tabela 6.6), foi possível realizar uma relação entre eles, como mostrado no APÊNDICE G e de forma gráfica na Figura 6.8.

\section{Figura 6.8 - Densidade de energia gerada e degradação das tecnologias fotovoltaicas}

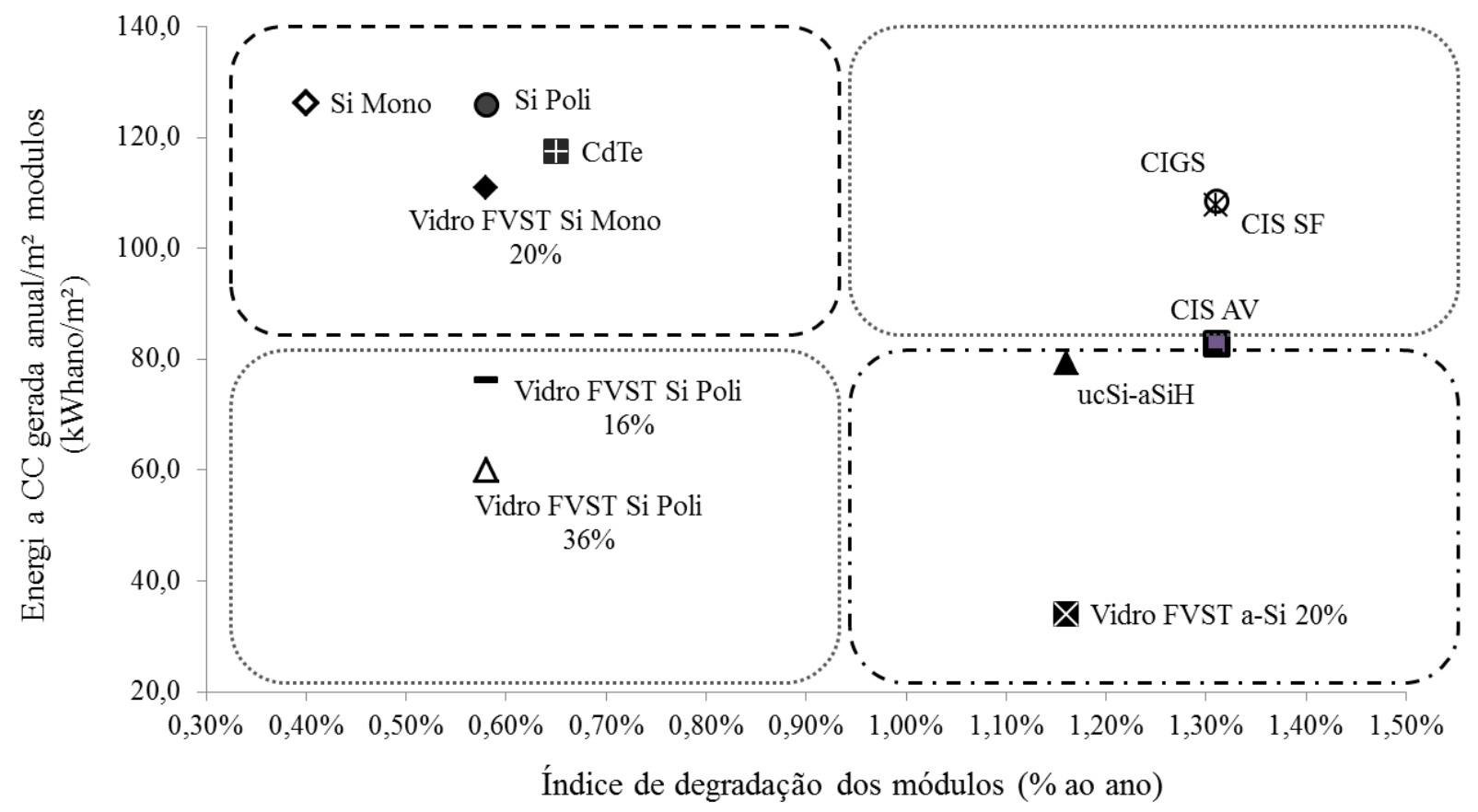

Fonte: Próprio autor (2017).

O gráfico acima mostra quatro quadrantes que classificam cada uma das tecnologias simuladas: o quadrante com contorno pontilhado agrupa as tecnologias com a melhor condição resultante do maior grau de densidade de energia gerada por metro quadrado do arranjo fotovoltaico com os menores índices de degradação dos módulos. Nessa condição e na ordem do melhor para o pior caso se enquadraram as tecnologias de silício cristalino (mono e policristalino) em painéis rígidos, de telureto de cadmio e de vidro fotovoltaico semitransparente que utiliza o silício monocristalino. Isso é justificado por serem as tecnologias mais maduras no mercado mundial, principalmente a de silício cristalino.

Por outro lado, as tecnologias que utilizaram o silício amorfo em sua formação, tanto em sistema Tandem como no vidro fotovoltaico semitransparente, apresentaram os priores resultados dentre os casos simulados, isto é, menor grau de densidade de energia gerada com 
maiores índices de degradação dos módulos. Essa categoria está contida no quadrante com contorno traço-ponto.

Em níveis intermediários se apresentaram as demais tecnologias simuladas, como as do grupo CIS/CIGS com bom grau de densidade de energia gerada prejudicado pelo maior índice de degradação dos módulos, e as do grupo de vidros fotovoltaicos semitransparentes que utilizaram como base o silício policristalino. Esses últimos, apesar de seu baixo grau de degradação, apresentaram densidades de energia gerada em patamares menores.

\subsection{Eficiência e ganho de energia gerada no inverno}

Outra análise que pôde se desenvolvida, mesmo que de forma mais macro, é relativa ao ganho de energia gerada no inverno em relação ao verão e as influências da radiação difusa no comportamento de cada tecnologia simulada.

Para tanto, foi elaborado um gráfico em que se classificou cada tecnologia com base em sua densidade de energia gerada e em seu ganho percentual no inverno em relação ao produzido no verão, conforme mostrado no APÊNDICE H e na Figura 6.9.

Figura 6.9- Densidade de energia gerada e sua variação entre estações verão-inverno

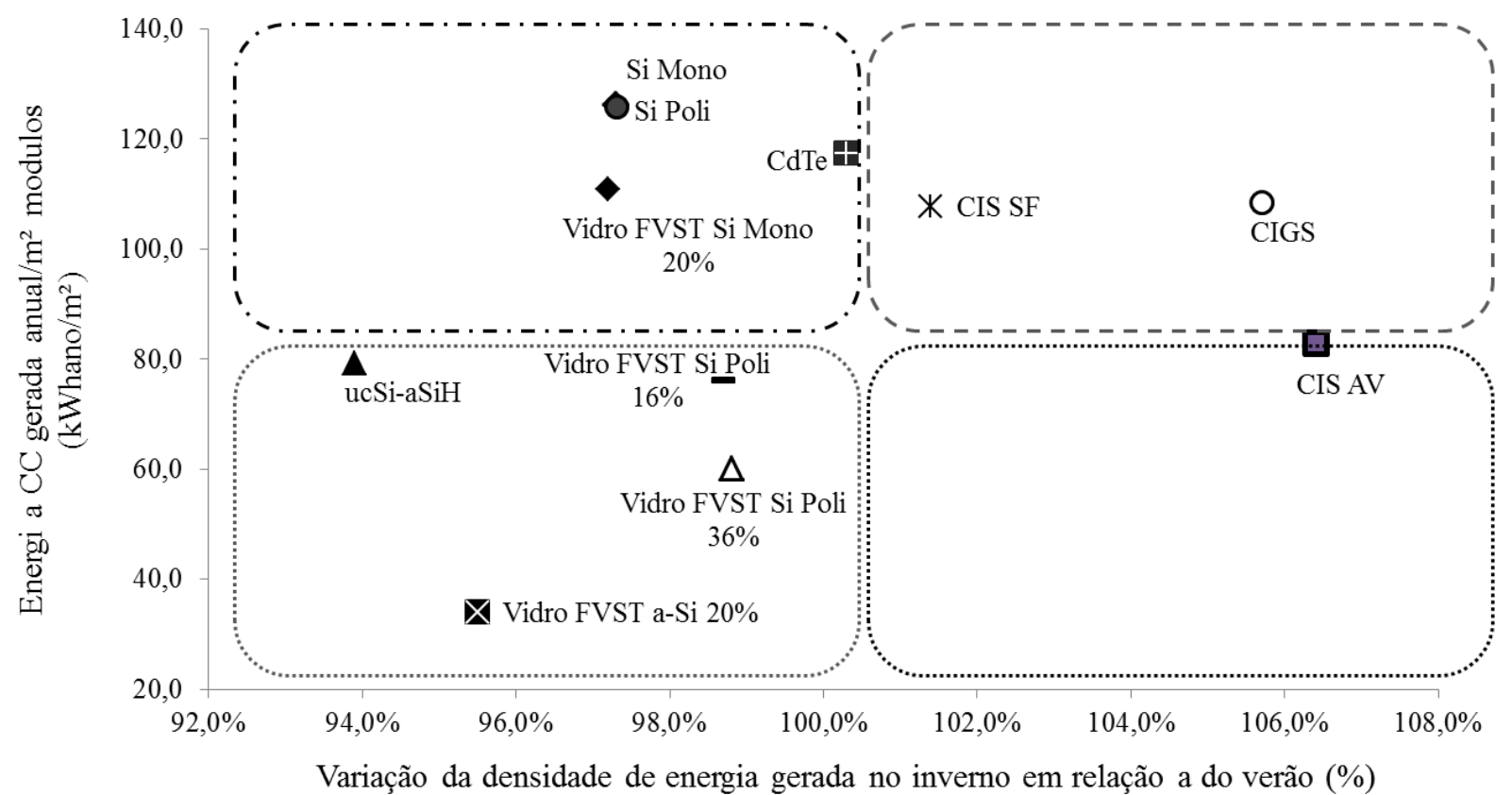

Fonte: Próprio autor (2017). 
O gráfico da Figura 6.9 mostra que as tecnologias fotovoltaicas mais adequadas em termos de densidade de produção de energia por unidade de área do arranjo de módulos são aquelas posicionadas nos dois quadrantes superiores.

As tecnologias do grupo do silício cristalino, mono e poli, se mostraram como as de melhor desempenho nesse quesito, porém mais adequadas para aplicações nos casos em que se requeira uma maior demanda de consumo nas épocas de temperaturas mais altas, como o verão, pois apesar de terem apresentado um ganho de energia gerada no inverno, é comparativamente menor que o das tecnologias CIS/CIGS. Portanto, essas tecnologias, que estão inseridas no quadrante com contorno traço-ponto, são recomendadas para aplicações em fachadas de edifícios comerciais, em que a demanda maior seria dos sistemas de ar condicionado no verão.

Por outro lado, as tecnologias de filmes finos do grupo CIS/CIGS, apesar de terem apresentado uma densidade de energia gerada um pouco inferior que a do grupo do silício cristalino, ofereceu um ganho maior na geração de energia no inverno em relação a do verão, indicando uma melhor aplicação nos casos em que se necessite mais energia nas estações mais frias e nubladas do ano. Essas tecnologias, que fazem uso maior da parcela de radiação difusa, estão posicionadas no quadrante com contorno pontilhado, e são as mais adequadas às fachadas de edifícios residenciais, em que há um acréscimo de demanda de energia proveniente de chuveiros elétricos e aquecedores durante o inverno. 


\section{CONCLUSÃO}

Entre 2011 e 2012, vislumbrava-se o início da consolidação do mercado fotovoltaico no Brasil baseado nas iniciativas que vinham sendo tomadas pelos agentes governamentais e normativos. Foi um momento de expectativas positivas, que não se desenvolveu como se previa, devido à desaceleração do crescimento econômico do país, a desarticulação das ações entre o Governo e os agentes da cadeia produtiva, a escassez de fomentos para alavancar a tecnologia em uma fase inicial e a ausência de Políticas claras voltadas ao desenvolvimento tecnológico e industrial.

Nos anos mais recentes, nos deparamos com um cenário crítico em relação à geração e ao abastecimento de energia elétrica no Brasil, o que veio a ser um fator motivador para o desenvolvimento da tecnologia fotovoltaica.

Com base nas experiências de outros países e nas novas tecnologias fotovoltaicas, com maior eficiência e maior flexibilidade de aplicação nos edifícios, o Brasil pode se reorganizar e estabelecer a sua diretriz no caminho da consolidação da tecnologia no País.

Embora a disseminação dessa tecnologia dependa principalmente da queda dos custos dos de seus componentes, o sistema solar fotovoltaico como elemento fonte de uma usina em geração distribuída, está sendo visto como a melhor solução para aplicação em centros urbanos, devido a sua proximidade de redes públicas para conexão, maior flexibilidade na disposição do sistema e na ocupação de solo, e menor influência do relevo do local na eficiência de geração.

Acompanhando a crescente demanda de moradias em apartamentos, principalmente nos centros urbanos, alternativas de aplicação das tecnologias fotovoltaicas vêm surgindo no sentido de reduzir a sua ocupação de áreas horizontais dos edifícios, e ao mesmo tempo gerar mais energia elétrica convertida per capita aos condôminos. Assim, outros elementos que formam o envelopamento do edifício, além da cobertura e do ático, vêm sendo considerados para tal finalidade, como as janelas e fachadas.

Em função da forma de instalação dos módulos fotovoltaicos no edifício são definidos dois conceitos de sistema: o BIPV - Building Integrated Photovoltaic (fotovoltaico integrado à edificação) e o BAPV - Building Attached (ou Adapted) Photovoltaic (fotovoltaico anexado ou adaptado à edificação).

A adoção de tecnologias fotovoltaicas aplicadas em sistema BIPV é concebida, geralmente, na fase de projeto ou de construção do empreendimento, substituindo elementos estruturais ou arquitetônicos do envelopamento do edifício. Apesar de apresentar maior interação com a 
arquitetura da fachada, suas propriedades funcionais devem atender às exigências normativas do setor de construção civil de cada país, fato que dificulta uma maior disseminação dessa medida. Além disso, a falta de ventilação na parte posterior dos módulos fotovoltaicos ocasiona uma perda maior em sua eficiência de conversão de energia em relação a do sistema $B A P V$.

Já as tecnologias em sistema $B A P V$ são dispostas de forma não integrada funcionalmente ao envelopamento do edifício, podendo ser aplicadas tanto em edifícios novos como serem adaptadas aos existentes. Essa flexibilidade permite a aplicação de tecnologias fotovoltaicas mais maduras, como a dos painéis rígidos de silício cristalino.

Este estudo apresentou uma revisão bibliográfica do estado-da-arte de tecnologias de células fotovoltaicas e uma análise de desempenho energético com base em simulações para tomada de decisão técnica sobre as tecnologias mais adequadas para sistemas a serem instalados em fachadas de edifícios. A tomada de decisão foi vista pela perspectiva de desempenho na geração de energia elétrica, mediante análise comparativa dos resultados de simulações aplicadas em um edifício hipotético em São Paulo, utilizando as tecnologias de silício cristalino e de filmes finos (BAPV), e de vidros fotovoltaicos $(B I P V)$.

O método adotado no desenvolvimento deste trabalho contou com o apoio de um software (neste caso o PVSYST) como ferramenta auxiliar no processo de simulação.

A escolha das tecnologias fotovoltaicas simuladas teve como critério básico cinco variáveis, a saber: disponibilidade da tecnologia e do modelo do módulo fotovoltaico no banco de dados do PVSYST, disponibilidade para comercialização pelos fabricantes, condição de aprovação pelo INMETRO e relevância na participação no mercado mundial, quanto a sua eficiência e a capacidade instalada.

Dentro desses critérios foram selecionadas as tecnologias dos seguintes fabricantes: Vidursolar (Espanha), Nexpower (Taiwan), SchottSolar (Alemanha), SolarWatt (Alemanha), Canadian (Canadá), FirstSolar (EUA), Avancis (Alemanha), Solar Frontier (Alemanha), TSMC Solar (Alemanha).

A simulação das tecnologias foi balizada por um procedimento que adotou como princípio básico a minimização de variáveis diferentes na composição do sistema fotovoltaico, a fim de facilitar a comparação dos resultados simulados. Os parâmetros comuns a todos os casos simulados foram: arranjo fotovoltaico na fachada Norte do edifício hipotético de 20 andares, livre de elementos de sombreamento, no município de São Paulo, cujas coordenadas de Latitude e de Longitude são, respectivamente, $23,5^{\circ} \mathrm{S}$ e $46,6^{\circ} \mathrm{W}$, altitude de 760 metros, 
ângulo de inclinação dos módulos em $90^{\circ}$ (montagem vertical) em montagem fixa e sem adoção de sistema de seguidor solar.

Analisando sob o ponto de vista dos resultados obtidos na saída do gerador fotovoltaico (em corrente contínua), este estudo contou com alguns parâmetros fixos para cada tecnologia, e, portanto, sem influência em sua eficiência durante o ano, tais como: índice de sujidade, degradação física zero, área do arranjo fotovoltaico, resistência natural e índice de absorção do material semicondutor e resistência elétrica das conexões. Outras variáveis como: localidade da instalação, condições ambientais e posicionamento do arranjo de módulos foram comuns a todas as simulações. Assim, pôde-se avaliar o comportamento de cada tecnologia fotovoltaica simulada em função de sua respectiva resposta espectral, com base em seus desempenhos em cada estação do ano.

As simulações forneceram resultados de energia elétrica gerada para cada tipo de tecnologia selecionada, quer seja em valores absolutos ou em forma de densidade de energia gerada por área ocupada pelos módulos fotovoltaicos.

Com base nos resultados obtidos pôde-se chegar a algumas conclusões:

- As tecnologias que apresentaram os melhores desempenhos, com base em sua densidade de energia gerada por unidade de área do arranjo, foram as do grupo de silício cristalino (mono e poli) na forma de painéis rígidos, evidenciando o motivo pelo qual são atualmente as mais comercializadas. As tecnologias com resultados mais próximos delas foram a de telureto de cadmio com desempenho $7 \%$ menor, seguido pelos filmes finos CIS e CIGS com comportamento inferior em 14\% a $15 \%$ em relação ao do silício cristalino em painéis rígidos (desconsiderando o produto do fabricante Avancis). As demais tecnologias apresentaram diferenças, em relação a mesma referência, na faixa de $37 \%$ a $73 \%$, salvo o caso do vidro fotovoltaico semitransparente (FVST) do fabricante SolarWatt com 12\% (silício monocristalino).

- Os desempenhos energéticos dos módulos de vidro FVST com base no silício cristalino ou amorfo, foram menores comparando-os com os dos painéis rígidos formados com mesma tecnologia de célula, como era previsto. No entanto, as diferenças de desempenho entre eles (vidros FVST) foram significativas: $61 \%$ de diferença entre os casos que adotaram como base o silício monocristalino e o silício amorfo, $31 \%$ a $45 \%$ de diferença entre os casos com silício monocristalino e aqueles com silício policristalino. Que se pesem os diferentes níveis de semitransparência pôde-se concluir que, ao se tratar de vidros FVST não seria viável tecnicamente 
considerar as alternativas que tenham como base o silício policristalino e o silício amorfo, dando preferência aos casos que adotem o silício monocristalino.

- O grupo de tecnologia CIS/CIGS apresentou o melhor resultado de variação de ganho de densidade de energia por metro quadrado do arranjo, gerando 104,5\% a mais de energia no inverno em relação ao verão. A tecnologia de telureto de cadmio veio logo abaixo com $4 \%$ a menos. As demais tecnologias simuladas tiveram resultados bem inferiores com diferenças na faixa de $7 \%$ a $10 \%$ comparados aos do CIS/CIGS, indicando menor aproveitamento da fração de radiação difusa.

- As tecnologias com as melhores condições resultantes do maior grau de densidade de energia gerada por metro quadrado do arranjo fotovoltaico com os menores índices de degradação anual dos módulos foram as de silício cristalino (mono e poli) em painéis rígidos, de telureto de cadmio e de vidro fotovoltaico semitransparente com silício monocristalino. Isso é justificado por se basearem em tecnologias mais maduras de células do mercado mundial, principalmente a de silício cristalino. Por outro lado, as tecnologias que utilizaram o silício amorfo em sua formação, tanto em sistema Tandem como no vidro fotovoltaico semitransparente, apresentaram os priores resultados dentre os casos simulados, Em níveis intermediários se apresentaram as demais tecnologias simuladas, como as do grupo CIS/CIGS.

- Dentre as tecnologias com melhor desempenho em densidade de geração de energia, as do grupo do silício cristalino (mono e poli) se mostraram como as mais adequadas para aplicações nos casos em que se requeira uma maior demanda de consumo nas épocas de calor intenso, como o verão. Sendo assim, essas tecnologias, são recomendadas para aplicações em fachadas de edifícios comerciais, em que a demanda energética aumenta de forma acentuada em consequência da utilização intensa de aparelhos de ar-condicionado. Além disso, o período diário de maior consumo de energia é coincidente com o da geração solar.

- Dentre as tecnologias com melhor desempenho em densidade de geração de energia, as do grupo do CIS/CIGS indicaram uma melhor aplicação nos casos em que se necessite de mais energia nas estações mais frias e nubladas do ano. Essas tecnologias, que fazem uso maior da parcela de radiação difusa, são as mais adequadas às fachadas de edifícios residenciais, em que há um acréscimo de demanda de energia proveniente de chuveiros elétricos e aquecedores durante o inverno. 
Fazendo um balanço global dos resultados obtidos, concluiu-se que as tecnologias com base no silício cristalino ainda são as mais indicadas para aplicações como sistemas $B A P V$ em fachadas de edifícios, principalmente nos casos em que há necessidade de atender maiores demandas de energia no verão. Próximo a esse desempenho estão os módulos de telureto de cadmio, porém com a preocupação relativa ao seu maior grau de toxidade, o que deve ser pesado no momento de uma decisão.

Por outro lado, os filmes finos de CIS/CIGS como sistemas BAPV são mais recomendados para os projetos que necessitem de maior geração de energia no inverno. Apesar de seu maior aproveitamento da fração de radiação difusa (6,6\% a mais no inverno), seu índice de degradação anual é maior que o da tecnologia de silício cristalino (mais que o dobro em índice percentual), além de seu desempenho anual em densidade de produção de energia ser inferior em $4 \%$ a $5 \%$ em relação ao do grupo do silício cristalino.

Algumas propriedades são favoráveis à tecnologia CIS/CIGS quando se trata dos aspectos arquitetônicos: podem ser projetados em cores ou impressos com desenhos, ou ainda com ajustes do grau de transparência ou translucidez. Além disso, o coeficiente de baixa temperatura dos módulos CIGS resulta em um rendimento energético significativamente melhor, apesar do aumento do calor superficial em comparação ao dos módulos solares cristalinos. No entanto, tanto esta tecnologia quanto a de telureto de cadmio sofrem o efeito chamado de light soaking, ou imersão de luz, cuja característica é o aumento de sua eficiência após um tempo de exposição à radiação solar. Esse efeito tem uma influência relevante no dimensionamento do sistema fotovoltaico, pois a tensão de circuito aberto do módulo pode aumentar em até $6 \%$ após algumas centenas de horas de exposição à irradiação solar.

Já as tecnologias com base no silício apresentam um efeito de degradação induzida pela luz, (LID) chamada de efeito Staebler-Wronski $(S W)$, causando uma redução em seu desempenho elétrico. Essa redução acontece nas primeiras horas de operação do módulo de silício cristalino em torno de $2 \%$, sendo que para o silício amorfo isso ocorre nos primeiros três a cinco meses de aplicação na ordem de $15 \%$ a $35 \%$, estabilizando sua eficiência em valores próximos ao nominal do fabricante após esse período.

Mesmo que o mercado mundial para aplicação de sistemas $B I P V$ e de $B A P V$ não tenham apresentado um crescimento como era previsto, vem surgindo uma ampla gama de oportunidades para a energia solar dentro do conceito de arquitetura sustentável. A crescente demanda por edifícios de energia quase zero vem contribuindo para redirecionar a visão de envoltória do edifício: de uma barreira passiva para um elemento sensível, ativo e adaptável. 
A indústria e o mercado do setor da construção civil vêm estimulando gradualmente a inovação de seus sistemas, processos e produtos. No entanto, em que se pesem os custos e os conflitos existentes entre os códigos da construção civil, há necessidade de um esforço adicional, à luz de uma abordagem interdisciplinar e colaborativa, de todos os atores da cadeia produtiva da construção civil. 


\section{REFERÊNCIAS BIBLIOGRÁFICAS}

AGENCIA NACIONAL DE ENERGIA ELÉTRICA (ANEEL). Agenda Regulatória 2015/2016. 2015. Disponível em:

<http://www.aneel.gov.br/area.cfm?idArea=703\&idPerfil=2\&idiomaAtual=0 >. Acesso em out. 2015

AGÊNCIA NACIONAL DE ENERGIA ELÉTRICA (ANEEL). Biblioteca: Glossário. Disponível em: <http://www.aneel.gov.br/biblioteca/glossario.cfm?att=T >. Acesso em 03 nov. 2015.

AGÊNCIA NACIONAL DE ENERGIA ELÉTRICA (ANEEL). Cadernos temáticos Micro e Minigeração Distribuída - Sistema de compensação de energia elétrica. $2^{\mathrm{a}}$ edição. Brasília DF, mai/16. Disponível em: <http://www.aneel.gov.br/documents/656877/14913578/Caderno+ +tematico+Micro+e+Minigera\%C3\%A7\%C3\%A3o+Distribuida+-+2+edicao>. Acesso em 11 set. 2016.

AGÊnCIA NaCiOnal DE ENERGia ElÉtriCA (ANeEL). Procedimentos de Distribuição no Sistema Elétrico Nacional - PRODIST. 2012. Módulo 3: Acesso ao sistema de distribuição. Brasília, DF. Disponível em:

<http://www.aneel.gov.br/arquivos/PDF/Módulo3_Revisao_5_Retificação_1.pdf>. Acesso em abr. 2013.

AGÊNCIA NACIONAL DE ENERGIA ELÉTRICA (ANEEL). Resolução Normativa nº 414/2010. Estabelece as condições gerais de fornecimento de energia elétrica: Direitos e deveres do consumidor d e energia elétrica, atualizada até a REN 499/2012. Brasília, DF, 2012. Disponível em:

<http://www.aneel.gov.br/biblioteca/downloads/livros/REN_414_2010_atual_REN_499_201 2.pdf >. Acesso em out. 2015.

AGÊNCIA NACIONAL DE ENERGIA ELÉTRICA (ANEEL). Resolução Normativa nº 482 de 17 de Abril de 2012. Estabelece as condições gerais para o acesso de microgeração e minigeração distribuída aos sistemas de distribuição de energia elétrica, o sistema de compensação de energia elétrica, e dá outras providências. Brasília, DF. Disponível em: <www.aneel.gov.br/cedoc/ren2012482.pdf>. Acesso em mar. 2013.

AGÊNCIA NACIONAL DE ENERGIA ELÉTRICA (ANEEL). Resolução Normativa n . 687 de 24 de Novembro de 2015. Altera a Resolução Normativa $n^{\circ} 482$, de 17 de abril de 2012, e os Módulos 1 e 3 dos Procedimentos de Distribuição - PRODIST. ANEEL, Brasília, DF. Disponível em: <http://www2.aneel.gov.br/cedoc/ren2015687.pdf>. Acesso em mai. 2016.

ASSOCIAÇÃO BRASILEIRA DE NORMAS TÉCNICAS (ABNT). NBR 16274: Sistemas fotovoltaicos conectados à rede - requisitos mínimos para documentação, ensaios de comissionamento, inspeção e avaliação de desempenho. Rio de Janeiro, abr. 2014. 
ASSOCIAÇÃO BRASILEIRA DE NORMAS TÉCNICAS (ABNT). NBR 16149: Sistemas fotovoltaicos $(\mathrm{FV})$ - Características da interface de conexão com a rede elétrica de distribuição. Rio de Janeiro, mar. 2013.

ASSOCIAÇÃO BRASILEIRA DE NORMAS TÉCNICAS (ABNT). NBR 5410: Instalações elétricas de baixa tensão - versão corrigida. Rio de Janeiro, mar. 2008.

ATLAS Solarimétrico do Brasil: Banco de dados solarimétricos. Chigueru Tiba... et al, 2000. 1 atlas. Escalas variam.111 p.

BANCO DE INFORMAÇÕES DE GERAÇÃO (BIG) [da] Agencia Nacional de Energia Elétrica (ANEEL). Brasília, Fev. 2017. Mensal. Disponível em:

<http://www2.aneel.gov.br/aplicacoes/capacidadebrasil/capacidadebrasil.cfm. >. Acesso em 15 fev. 2017.

BAUMGAERTNER, J. PV principles. Green Rhino Energy. London, UK, 2013. VAT registration: GB109451818. Disponível em: 〈http://www.greenrhinoenergy.com>. Acesso em 05 out. 2015.

BOLETIM DIÁRIO DA OPERAÇÃO: ENERGIA ARMAZENADA [do] Operador Nacional do Sistema Elétrico (ONS). Rio de Janeiro, Ago. 2015. Diário. Disponível em: < http://www.ons.org.br/resultados_operacao/boletim_diario >. Acesso em 02 set. 2015.

\section{BOLETIM MENSAL DE MONITORAMENTO DO SISTEMA ELÉTRICO}

BRASILEIRO [da] Secretaria de Energia Elétrica do Ministério de Minas e Energia (MME). Brasília, Dez. 2016. Mensal. Disponível em:

<http://www.mme.gov.br/documents/10584/3308684/Boletim+de+Monitoramento+do+Siste ma+El\%EF\%BF\%BDtrico+-+Dezembro-2016.pdf/f6b5284d-4105-4b79-a030-

$31755664721 \mathrm{a}>$. Acesso em 15 fev. 2017.

BRASIL. Câmara Brasileira da Indústria da Construção (CBIC). Pesquisa nacional da

Câmara Brasileira da Indústria da Construção: A Inovação na Construção Civil no Brasil sob a Ótica do Consumidor. Brasília, DF, Instituto Sensus, Mar. 2014. Disponível em:

$<$ http://www.cbic.org.br/sala-de-imprensa/noticia/inovacao-na-construcao-civil-no-brasil-soba-otica-do-consumidor>. Acesso em 23 jun. 2015.

BRASIL. Conselho Nacional de Política Fazendária (CONFAZ). Convênio ICMS n¹6 (Goiás, Pernambuco e São Paulo) de 27 de Abril de 2015: isenção do ICMS na energia compensada na micro e minigeração de energia elétrica. Brasília: Abr. 2015. Disponível em: <www.confaz.fazenda.gov.br/legislacao/convenios>. Acesso em 20 jun. 2015.

BRASIL. Empresa de Pesquisa Energética (EPE). Nota Técnica DEA 28/13: Projeção da demanda de energia elétrica para os próximos 10 anos (2014-2023). Rio de Janeiro: MME, dez. 2013. Disponível em:

http://www.epe.gov.br/mercado/Documents/S\%C3\%A9rie\%20Estudos\%20de\%20Energia/20 140203_1.pdf. Acesso em fev. 2015.

BRASIL. Instituto Brasileiro de Geografia e Estatística (IBGE). Censo Demográfico 2010: Características da População e dos Domicílios: Resultados do Universo. Rio de Janeiro, 2013. Disponível em: http://censo2010.ibge.gov.br/apps/atlas. Acesso em 13 de jun. 2015. 
BRASIL. Instituto Nacional de Metrologia, Qualidade e Tecnologia (INMETRO). Portaria no. 004: Aprova a revisão dos Requisitos de Avaliação da Conformidade para Sistemas e Equipamentos para Energia Fotovoltaica, institui a etiquetagem compulsória de sistemas e equipamentos para energia fotovoltaica, estabelece os critérios para o Programa de Avaliação da Conformidade para sistemas e equipamentos para energia fotovoltaica, através da utilização da Etiqueta Nacional de Conservação de Energia (ENCE). Rio de Janeiro, 2011. Disponível em: <http://www.inmetro.gov.br/legislacao/rtac/pdf/RTAC001652.pdf>. Acesso em 30 out. 2015.

BRASIL. Instituto Nacional de Metrologia, Qualidade e Tecnologia (INMETRO). Portaria $\mathbf{n}^{\mathbf{0}} . \mathbf{2 4 0}$ de 18 de maio de 2015. Declara aberta a Consulta Pública para aperfeiçoamento dos requisitos de avaliação da conformidade para sistemas e equipamentos para Energia Fotovoltaica (Módulo, Controlador de Carga, Inversor e Bateria), disponibiliza a proposta de texto de portaria definitiva. INMETRO, Rio de Janeiro, 2015. Disponível em:

<http://www.inmetro.gov.br/legislacao/rtac/pdf/RTAC002254.pdf>. Acesso em 30 out. 2015

BRASIL. Instituto Nacional de Metrologia, Qualidade e Tecnologia (INMETRO). Portaria no . 357: Aprova a adequação aos Requisitos de Avaliação da Conformidade para Sistemas e Equipamentos para Energia Fotovoltaica, determina sobre os ensaios realizados por laboratórios estrangeiros, complementa o Anexo III. Rio de Janeiro, 2014. Disponível em: <http://www.inmetro.gov.br/legislacao/rtac/pdf/RTAC002145.pdf >. Acesso em 30 out. 2015.

BRASIL. Instituto Nacional de Metrologia, Qualidade e Tecnologia (INMETRO). Programa Brasileiro de Etiquetagem: Tabelas de Consumo/Eficiência Energética - Componentes Fotovoltaicos - Inversores conectados à rede. Edição 29/06/2016. Disponível em: $<$ http://www.inmetro.gov.br/consumidor/pbe/componentes_fotovoltaicos_Inversores_OnGrid.pdf $>$. Acesso em 01 nov. 2015.

BRASIL. Lei $\mathbf{n}^{\circ} \mathbf{1 3 . 1 6 9}$, de 6 de outubro de 2016. Altera a Lei $\mathrm{n}^{\circ} 7.689$ de 15 de dezembro de 1988, para elevar [...] e dá outras providências. Brasília, DF: Casa Civil, 6/10/2015. Seção 1. Art. $8^{\circ}$ do Diário Oficial da União (DOU). Disponível em: <http://www.planalto.gov.br/ccivil_03/_Ato2015-2018/2015/Lei/L13169.htm>. Acesso em 15 fev. 2017.

BRASIL. Operador Nacional do Sistema Elétrico (O.N.S). Conheça o sistema. Rio de Janeiro: MME, Mar. 2015. Disponível em:

<http://www.ons.org.br/conheca_sistema/o_que_e_sin.aspx >. Acesso em 16 mar. 2015.

CENTRO DE REFERÊNCIA PARA ENERGIA SOLAR E EÓLICA SÉRGIO BRITO (CRESESB). Potencial Energético Solar - SunData: Base de dados de radiação solar incidente - localidades próximas. Disponível em:

<www.cresesb.cepel.br/sundata/index.php\#sundata>. Acesso em 30 mar. 2013.

COSTA, M. Conta de luz deve subir em média $42 \%$ no ano. Jornal Folha de S. Paulo, São Paulo, 7 Fev. 2015. Disponível em:

<http://www1.folha.uol.com.br/mercado/2015/02/1586581-conta-de-luz-deve-subir-emmedia-42-no-ano.shtml >. Acesso em 06 mar. 2015. 
COSTA, H. J. S. da. Avaliação do Fator de Dimensionamento do Inversor em Sistemas Fotovoltaicos conectados a rede. Fortaleza: Universidade Federal do Ceará - Centro de Tecnologia, 2010. Módulo fotovoltaico e Fator de Dimensionamento do Inversor. Disponível em: <www.dee.ufc.br/.../Monografia\%20-20Jose\%20Serafim\%20da\%20Cost...>. Acesso em 13 mai. 2013.

CRAIDE, S. Bandeiras tarifárias terão novos valores neste ano. Agencia Brasil EBC, Brasília, 14 Fev. 2017. Disponível em:

$<$ http://agenciabrasil.ebc.com.br/economia/noticia/2017-02/bandeiras-tarifarias-terao-novosvalores-em-2017>. Acesso em 15 fev. 2017.

DEL CUETO, J. A.; VON ROEDEM, B. Long-term transient and metastable effects in cadmium telluride photovoltaic modules. Prog. Photovolt: Res. Appl., 14: 615-628. doi:10.1002/pip.687. National Renewable Energy Laboratory (NREL), USA. Mai. 2006. Disponível em: <http://onlinelibrary.wiley.com/doi/10.1002/pip.663/full〉. Acesso em out. 2015.

DUFFIE, J. A.; BECKMAN, W. A. Solar Engineering of Thermal Processes. $3^{\text {rd }}$ ed. New Jersey, USA, Wiley, 2006. Includes Index. ISBN 13 978-0-471-69867-8;10 0-471-69867-9 (cloth).

ESPOSITO, A.S.; FUCHS, P.G. Desenvolvimento tecnológico e inserção da energia solar no Brasil. Revista do BNDES 40, p. 85-113. Rio de Janeiro, Dez. 2013. Disponível em: http://www.bndes.gov.br/SiteBNDES/export/sites/default/bndes_pt/Galerias/Arquivos/conhec imento/revista/rev4003.pdf>. Acesso em 20 fev. 2015.

EUROPEAN PHOTOVOLTAIC INDUSTRY ASSOCIATION (EPIA). Global Market Outlook - for Photovoltaics 2014-2018. Sweden, 2014. Disponível em:

$<$ http://www.cleanenergybusinesscouncil.com/global-market-outlook-for-photovoltaics-20142018-epia-2014>. Acesso em 12 mar. 2015.

GRANDIN, F. China e Europa dominam mercado: europeus têm mais da metade da capacidade solar instalada, e asiáticos lideram fabricação de módulos e painéis fotovoltaicos. Brasil Energia, Rio de Janeiro, 2013. Disponível em: <http://brasilenergia.editorabrasilenergia.com>. Acesso em 12 ago. 2014.

GREEN, M. A.; EMERY, K.; HISHIKAWA, Y.; WARTA, W.; DUNLOP, E. D. Solar cell efficiency tables. Progress in photovoltaics: research and applications. Prog. Photovolt: Res. Appl. 2015; 23: 1-9. Australia, 2014. Disponível em:

<http://onlinelibrary.wiley.com/doi/10.1002/pip.2573/abstract>. Acesso em set. 2015.

GREEN, M. A.; EMERY, K.; HISHIKAWA, Y.; WARTA, W.; DUNLOP, E. D. Solar cell efficiency tables. Progress in photovoltaics: research and applications. Prog. Photovolt:; Edition 48. Australia, 2016. Disponível em:

<http://onlinelibrary.wiley.com/doi/10.1002/pip.2573/abstract>. Acesso em jun. 2016.

GRIMM, A. M. Meteorologia Básica - Notas de Aula, capítulo 2 - Radiação solar e terrestre. Universidade Federal do Paraná - Dep. Física, set/1999. Disponível em:

<http://fisica.ufpr.br/grimm/>. Acesso em 20 ago. 2016. 
GUNTHER, M. Are Glowing Reports of New Solar Cell Material Mostly Hype? Chemistry word, Mar. 2015. Disponível em: <www.scientificamerican.com/article>. Acesso em 18 abr. 2015.

INGEMECANICA. Tutorial 192: Instalación Solar Fotovoltaica para vivenda. Espanha. Disponível em: <http://ingemecanica.com/tutorialsemanal/tutorialn192.html>. Acesso em 15 fev. 2017.

INTERNATIONAL ENERGY AGENCY (IEA). Solar Photovoltaic Energy. Technology Roadmap 2014 edition. France, 2014. Disponível em: <http://www.iea.org>. Acesso em 19 abr. 2015.

JARDIM, C. S.; RÜTHER, R.; SALAMONI, I. T.; VIANA, T.; REBECHI, S. H.; KNOB, P. The strategic siting and the roofing area requirements of building-integrated photovoltaic solar energy generators in urban areas in Brazil. Energy and Buildings, v. 40, p. 365-370, 2007.

JELLE, B. P.; BREIVIK, C. State-of-the-art building integrated photovoltaics. Norwegian University of Science and Technology. Energy Procedia 20 (2012) 68 - 77, Norway, 2012. Disponível online em: <www.sciencedirect.com>. Acesso em out. 2015.

JELLE, B. P. Building Integrated Photovoltaics: A Concise Description of the Current State of the Art and Possible Research Pathways. Norwegian University of Science and Technology. Energies 2016, 9, 21; doi:10.3390/en9010021. Norway, 2015. Disponível em: <www.mdpi.com/1996-1073/9/1/21/pdf>. Acesso em ago. 2016.

LASNIER, F.; ANG, T.G. Photovoltaic engineering handbook. New York: IOP Publishing, 1990. 548 p.

LIU, B. Y. H., JORDAN, R. C. The interrelationship and characteristic distribution of direct, diffuse and total solar radiation. Solar Energy, v.3, n.4, p.1-19, 1960.

LOPES, A. G. P. S. Dissertação preliminar: Controlo Avançado de Sistemas Fotovoltaicos. Portugal: Faculdade de Engenharia da Universidade do Porto, Fev. 2013. Inversores.

Disponível em: <paginas.fe.up.pt/ ee10225/wp.../EstadoArte_ee10225_AfonsoLopes.pdf >. Acesso em 20 Mar. 2013.

LÓPES, R. A.; GARCIA, M. A. Parámetros comparativos de células fotoeléctricas para generación de energía: implementación de banco de pruebas usando DSP. Universidad de Sucre, Colombia, 2014. Versión On-line. Publicado em Ingeniería Energética Vol. XXXV, 3/2014 p. 193- 201, Sep/Dic 2014. La Habana, Cuba. ISSN 1815 - 5901. Disponível em: $<$ http://scielo.sld.cu/scielo.php?script=sci_arttext\&pid=S1815-59012014000300004>. Acesso em 15 fev. 2017.

MACHADO, C. T.; MIRANDA, F. S. Energia Solar Fotovoltaica: Uma Breve Revisão. Rev. Virtual Quim., 2015, 7 (1), 126-143. Data de publicação na Web: 14 de outubro de 2014. ISSN 1984-6835. Disponível em: <http://www.uff.br/rvq>. Acesso em 13 nov. 2015. 
MAKRIDES, G.; ZINSSER, B.; PHINIKARIDES, A.; SCHUBERT, M.; GEORGHIOU, G. E. Temperature and thermal annealing effects on different photovoltaic technologies. Renewable Energy 43 (2012) 407E417. Germany, 2011. Disponível online em: <www.elsevier.com/locate/renene>. Acesso em out. 2015.

MARKVART, T.; CASTANER, L. Photovoltaics, fundamentals and Application. $2^{\text {nd }}$ ed. Amsterdam, The Netherlands, 2007. Includes Index. ISBN 1856173909.

MATURI, L.; BELLUARDO, G.; MOSER, D.; BUONO, M. D. BiPV system performance and efficiency drops: overview on PV module temperature conditions of different module types. Energy Procedia, v. 48. P. 1311-p. 1319, Italy, 2014. Disponível online em: <http://www.sciencedirect.com>. Acesso em out. 2015.

MERMOUD, A; WITTMER, B. PVSYST user's manual, PVSYST 6, Tutorial PVSYST SA. PVSYST SA, Switzerland, Jan/2014. Disponível em:

<www.pvsyst.com/images/pdf/PVsyst_Tutorials.pdf>. Acesso em 19 set. 2015.

METEONORM. Meteonorm Software: Irradiation and other weather data for any location on Earth. Switzerland, 2015. Disponível em: <http://meteonorm.com/en/downloads>. Acesso em out. 2015.

MINTS, P. 2015 Top Tem PV Cell Manufacturers. Nashua, USA, Apr. 2016. Renewable Energy World. Disponível em:

<http://www.renewableenergyworld.com/articles/2016/04/2015-top-ten-pv-cellmanufacturers.html>. Acesso em: jun. 2016.

MORENO, H. ABNT 5410/2004: vai começar (enfim) a revisão. Solar Energy Business, Edição 74, 2012. Disponível em: <http://docslide.com.br/documents/abnt-nbr-5410-comecoda-revisao.html>. Acesso em 02 out. 2015.

NATIONAL INSTRUMENTS CORPORATION (NI). Part II - Photovoltaic Cell I-V Characterization Theory and LabVIEW Analysis Code. Austin, EUA. Mai/2012. Disponível em: <http://www.ni.com/white-paper/7230/en/>. Acesso em 15 fev. 2017.

NATIONAL RENEWABLE ENERGY LABORATORY (NREL). Best Reasearch - Cell Efficiencies. US Department of Energy. USA, ago/2015. Disponível em: <https://www.nrel.gov/pv/assets/images/efficiency-chart.png>. Acesso em 24 out. 2015.

NOGUEIRA, A. F. Materiais Nanoestruturados e sua aplicação na área de conversão de energia solar. Campinas, 2013. Laboratório de Nanotecnologia e Energia Solar (LNES). Disponívem em: <www.Ines.iqm.unicamp.br>. Acesso em abr. 2015.

PANELES SOLARES PR. Energia Solar 101: Um curso corto sobre sistemas fotovoltaicos. Puerto Rico. Disponível em: <http://panelessolarespr.com/solar101.html>. Acesso em 15 fev. 2017.

PHOTON. PHOTON Database. Andover, USA, 2016. Disponível em: $<$ http://photon.info/en/photon-databases >. Acesso em jun. 2016. 
PORTAL O SETOR ELÉTRICO. Edição 110: Aplicações da ABNT NBR 5410. SP, Mar. 2015. Disponível em: <http://www.osetoreletrico.com.br/web/a-empresa/1631-aplicacoes-daabnt-nbr-5410.html>. Acesso em 30 out. 2015.

RAMPINELLI, G. A.; BÜHLER, J. Análise de diferentes tecnologias fotovoltaicas para instalações residenciais no Sul do Brasil. Santa Catarina, 2012. Publicado em Avances en Energías Renovables y Medio Ambiente (ASADES), Vol. 16, 2012. Argentina. ISSN 0329518.

RÜTHER, R. Edifícios Solares Fotovoltaicos: o potencial da geração solar fotovoltaica integrada a edificações urbanas e interligada à rede elétrica pública no Brasil.

Florianópolis: Editora UFSC/LABSOLAR, 2004.

RÜTHER, R.; SALOMONI, I. O potencial dos setores urbanos brasileiros para a geração de energia solar fotovoltaica de forma integrada às edificações. Fórum Patrimônio, Belo Horizonte, v. 4, n. 1, p. 84-94, 2011.

SOLAR POWER EUROPE. Global Market Outlook for Solar Power 2015-2019. Belgium, 2015. Disponível em: <http://www.solarpowereurope.org/insights/global-market-outlook>. Acesso em 28 out. 2015.

SOLAR POWER EUROPE. Global Market Outlook for Solar Power 2016-2020 - Webinar. Belgium, 2016. Disponível em:

<http://www.solarpowereurope.org/fileadmin/user_upload/documents/Events/SolarPower_W ebinar_Global_Market_Outlook.pdf>.Acesso em 15 fev. 2017.

SWISS BIPV COMPETENCE CENTRE, SOLAR ENERGY APPLICATION CENTRE (SUPSISEAC). BIPV Product overview for solar facades and roofs: BIPV status report 2015. Swiss, 2016. Disponível em: <http://www.seac.cc/fileadmin/seac/user/doc/SEAC-

SUPSI_report_2015_-_BIPV_product_overview_for_solar_facades_and_roofs_1_.pdf >. Acesso em jul. 2016.

US DEPARTMENT OF ENERGY. Photovoltaic Cell Conversion Efficiency Basics. Energy.gov. USA, 2013. Disponível em:

<http://energy.gov/eere/energybasics/articles/photovoltaic-cell-conversion-efficiency-basics>. Acesso em 20 jan. 2016.

ZILLES, R.; MACÊDO, W. N.; GALHARDO, M. A. B.; OLIVEIRA, S. H. F. de. Sistemas fotovoltaicos conectados à rede elétrica. São Paulo: Oficina de textos, 2012. ISBN 978-857975-052-6.

PIS E COFINS: Saiba O Que São E Como Calculá-Los. Disponível em: <http://www.sitecontabil.com.br/noticias/artigo.php?id=1174>. Acesso em 30 out. 2015. 


\section{APÊNDICE A - Resultados das simulações - Energia anual gerada por tecnologia}

\begin{tabular}{|c|c|c|c|c|c|c|c|c|c|}
\hline Fabricante & Tecnologia & $\begin{array}{c}\text { Irradiação } \\
\text { global efetiva }\end{array}$ & $\begin{array}{c}\text { Energia } \\
\text { de Saída } \\
\text { do } \\
\text { Gerador }\end{array}$ & $\begin{array}{c}\text { Energia } \\
\text { Injetada } \\
\text { na Rede }\end{array}$ & $\begin{array}{c}\text { Eficiência } \\
\text { do } \\
\text { Gerador }^{61}\end{array}$ & $\begin{array}{c}\text { Eficiência } \\
\text { do } \\
\text { Sistema }^{62}\end{array}$ & $\begin{array}{c}\text { Potência } \\
\text { nominal } \\
\text { CC }\end{array}$ & $\begin{array}{c}\text { Área } \\
\text { do } \\
\text { modulo }\end{array}$ & $\begin{array}{c}\text { Área } \\
\text { de } \\
\text { células }\end{array}$ \\
\hline & & $\mathrm{kWh} / \mathrm{m}^{2}$ ano & kWh/ano & kWh/ano & $\%$ & $\%$ & STC kWp & $\mathrm{m}^{2}$ & $\mathrm{~m}^{2} / \mathrm{mod}$ \\
\hline Canadian & Si-Mono (rígido) & 826,80 & $25.604,00$ & $24.710,00$ & 14,70 & 14,19 & 33,4 & 203,0 & 181,0 \\
\hline Canadian & Si-Poli (rígido) & 826,80 & $25.583,00$ & $24.692,00$ & 14,69 & 14,18 & 33,4 & 203,0 & 184,0 \\
\hline First Solar & CaTe (Filme Fino) & 814,40 & $23.722,00$ & $22.916,00$ & 13,70 & 13,23 & 32,2 & 202,0 & 189,0 \\
\hline Nexpower & ucSi-aSiH (Filme Fino) & 810,70 & $16.107,00$ & $15.003,00$ & 9,22 & 8,59 & 21,1 & 203,0 & 192,0 \\
\hline Avancis & CIS (Filme Fino) AV & 810,70 & $15.748,00$ & $15.185,00$ & 9,66 & 9,32 & 21,6 & 190,0 & 190,0 \\
\hline Solar Frontier & CIS (Filme Fino) SF & 810,70 & $21.130,00$ & $20.359,00$ & 12,52 & 12,06 & 27,2 & 196,0 & 196,0 \\
\hline TSMC Solar & CIGS (Filme Fino) & 810,70 & $23.327,00$ & $21.712,00$ & 12,62 & 11,75 & 31,7 & 215,0 & 195,0 \\
\hline Vidursolar & Vidro FVST (Si-Poli, 36\%) & 810,70 & $11.840,00$ & $11.025,00$ & 6,98 & 6,50 & 16,2 & 197,0 & 197,0 \\
\hline Vidursolar & Vidro FVST (Si-Poli, 16\%) & 810,70 & $15.454,00$ & $14.386,00$ & 8,87 & 8,26 & 21,1 & 203,0 & 203,0 \\
\hline Schott Solar & Vidro FVST (a-Si, 20\%) & 810,70 & $7.164,10$ & $6.765,80$ & 3,95 & 3,73 & 10,1 & 211,0 & 211,0 \\
\hline SolarWatt & Vidro FVST (Si-Mono, 20\%) & 810,70 & $25.159,00$ & $24.259,00$ & 12,92 & 12,46 & 33,6 & 227,0 & 227,0 \\
\hline
\end{tabular}

Fonte: próprio autor com base nos resultados do PVSYST (2016).

Condições de simulação: montagem vertical dos módulos na fachada do edifício em São Paulo, azimute da superfície $(\gamma)$ : $0^{\circ}$ pelo critério do PVSYST, inclinação da superfície ( $\beta$ ): 90², irradiação global no plano horizontal: $1.442,50 \mathrm{kWh} / \mathrm{m}^{2}$ ano, Temperatura ambiente média anual: $20,02^{\circ} \mathrm{C}$, irradiação global incidente no coletor plano após fator de transposição mas sem correções óticas: $859,20 \mathrm{kWh} / \mathrm{m}^{2} \mathrm{ano}$.

\footnotetext{
${ }^{60}$ Irradiação global efetiva sobre o módulo após perdas óticas.

${ }^{61}$ Energia de saída do gerador, dividido pelo produto da irradiação global incidente no coletor após transposição e a área do módulo.

${ }^{62}$ Energia injetada na rede, dividido pelo produto da irradiação global incidente no coletor após transposição e a área do módulo.
} 


\section{APÊNDICE B - Resultados das simulações - Perdas anuais no sistema fotovoltaico}

Irradiação Global no plano horizontal (GlobHor) $=1.442,50 \mathrm{kWh} / \mathrm{m}^{2}$ ano

Irradiação Global no plano do módulo $($ GlobInc $)=859,20 \mathrm{kWh} / \mathrm{m}^{2}$ ano

\begin{tabular}{|c|c|c|c|c|c|c|c|c|c|c|c|c|c|c|c|c|}
\hline \multirow{3}{*}{ Tecnologia de módulo FV } & \multicolumn{16}{|c|}{ Perdas anuais no sistema fotovoltaico } \\
\hline & 1 & 2 & 3 & $\begin{array}{c}\text { Área } \\
\text { arranjo }\end{array}$ & B & 4 & 5 & $\mathbf{5 a}$ & 6 & 7 & 8 & 9 & 10 & 11 & 12 & 13 \\
\hline & $\%$ & $\%$ & $\%$ & $\mathrm{~m}^{2}$ & $\%$ & $\%$ & $\%$ & $\%$ & $\%$ & $\%$ & $\%$ & $\%$ & $\%$ & $\%$ & $\%$ & $\%$ \\
\hline Si-Mono (rígido) & $-40,4$ & $-0,5$ & $-3,2$ & 203,0 & 16,54 & $-1,6$ & $-5,1$ & 0,0 & 0,5 & $-1,0$ & $-0,6$ & $-3,5$ & 0,0 & 0,0 & 0,0 & 0,0 \\
\hline Si-Poli (rígido) & $-40,4$ & $-0,5$ & $-3,2$ & 203,0 & 16,49 & $-1,8$ & $-4,9$ & 0,0 & 0,5 & $-1,0$ & $-0,6$ & $-3,5$ & 0,0 & 0,0 & 0,0 & 0,0 \\
\hline CaTe (Filme Fino) & $-40,4$ & $-0,5$ & $-4,7$ & 202,0 & 15,97 & $-2,0$ & $-4,0$ & 0,0 & $-2,5$ & $-0,8$ & $-0,6$ & $-3,4$ & 0,0 & 0,0 & 0,0 & 0,0 \\
\hline ucSi-aSiH (Filme Fino) & $-40,4$ & $-0,5$ & $-5,1$ & 203,0 & 10,57 & $-4,1$ & $-3,9$ & 0,9 & 0,7 & $-0,8$ & $-0,6$ & $-6,9$ & 0,0 & 0,0 & 0,0 & 0,0 \\
\hline CIS (Filme Fino) AV & $-40,4$ & $-0,5$ & $-5,1$ & 190,0 & 11,36 & $-4,9$ & $-5,2$ & 0,0 & 1,3 & $-0,8$ & $-0,6$ & $-3,5$ & 0,0 & 0,0 & 0,0 & 0,0 \\
\hline CIS (Filme Fino) SF & $-40,4$ & $-0,5$ & $-5,1$ & 196,0 & 13,90 & $-2,1$ & $-3,8$ & 2,0 & 0,7 & $-0,8$ & $-0,6$ & $-3,6$ & 0,0 & 0,0 & 0,0 & 0,0 \\
\hline CIGS (Filme Fino) & $-40,4$ & $-0,5$ & $-5,1$ & 215,0 & 14,73 & $-4,4$ & $-3,7$ & 2,5 & $-2,5$ & $-0,8$ & $-0,6$ & $-6,9$ & 0,0 & 0,0 & 0,0 & 0,0 \\
\hline Vidro FVST (Si-Poli, 36\%) & $-40,4$ & $-0,5$ & $-5,1$ & 197,0 & 8,24 & $-2,5$ & $-4,1$ & 0,0 & $-2,5$ & $-1,0$ & $-0,6$ & $-6,9$ & 0,0 & 0,0 & 0,0 & 0,0 \\
\hline Vidro FVST (Si-Poli, 16\%) & $-40,4$ & $-0,5$ & $-5,1$ & 203,0 & 10,46 & $-2,5$ & $-4,0$ & 0,0 & $-2,5$ & $-1,0$ & $-0,6$ & $-6,9$ & 0,0 & 0,0 & 0,0 & 0,0 \\
\hline Vidro FVST (a-Si, 20\%) & $-40,4$ & $-0,5$ & $-5,1$ & 211,0 & 4,82 & $-4,7$ & $-3,6$ & 1,0 & $-5,0$ & $-0,8$ & $-0,6$ & $-5,5$ & 0,0 & 0,0 & 0,0 & 0,0 \\
\hline Vidro FVST (Si-Mono, 20\%) & $-40,4$ & $-0,5$ & $-5,1$ & 227,0 & 14,83 & $-2,5$ & $-4,5$ & 0,0 & 0,7 & $-1,0$ & $-0,6$ & $-3,6$ & 0,0 & 0,0 & 0,0 & 0,0 \\
\hline
\end{tabular}

Fonte: próprio autor com base nos resultados do PVSYST (2016). 


\section{APÊNDICE C - Resultados das simulações - Energia mensal gerada por tecnologia}

Montagem vertical dos módulos na fachada do edifício

Azimute da superfície $(\gamma): 180^{\circ}$
Inclinação da superfície ( $\beta$ ): $90^{\circ}$
Parâmetros:

GlobHor

GlobInc
$1.442,50 \mathrm{kWh} / \mathrm{m}^{2}$

$859,20 \mathrm{kWh} / \mathrm{m}^{2}$

Energia mensal gerada (Earray) em corrente contínua [kWh/mês]

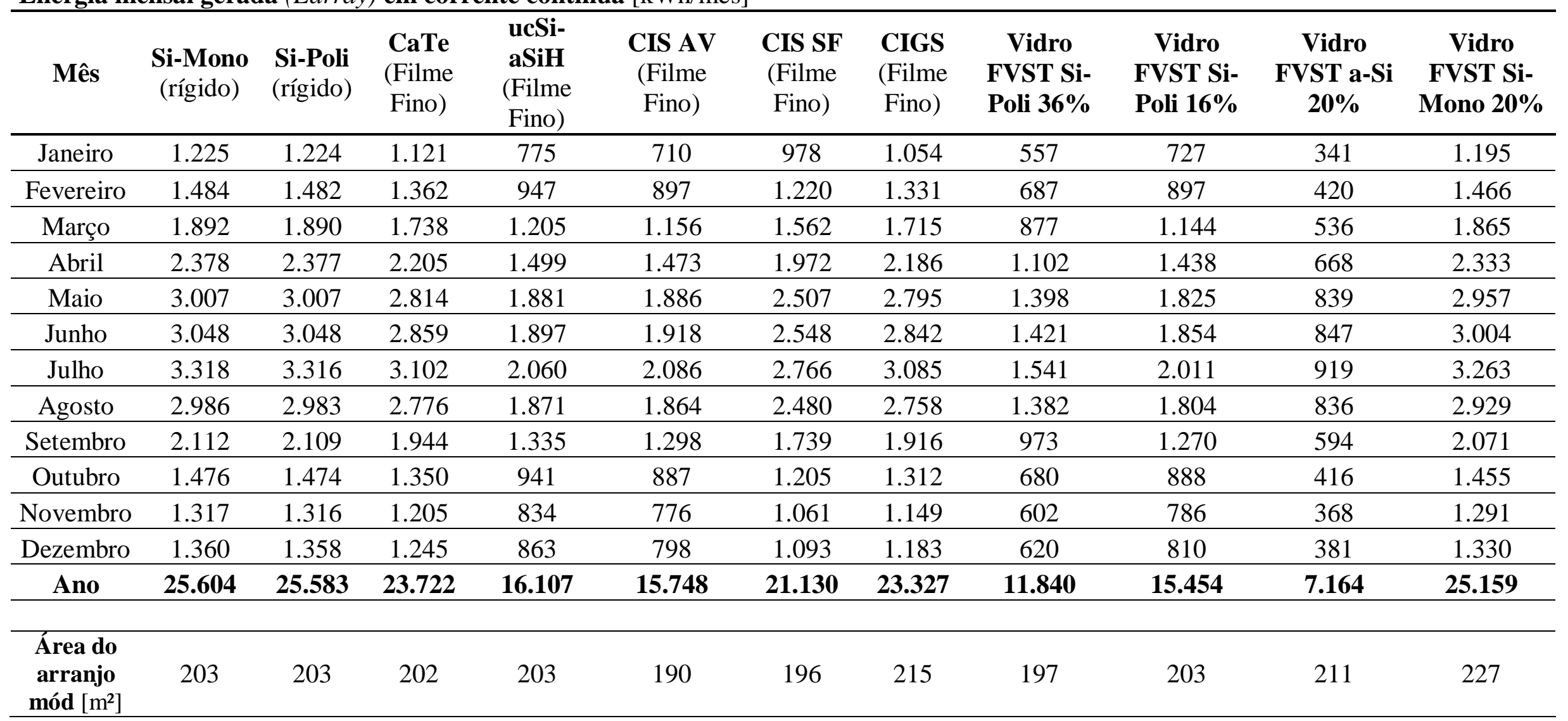

Fonte: próprio autor com base nos resultados do PVSYST (2016). 
APÊNDICE D - Energia gerada por estação do ano e por tecnologia

Energia gerada (Earray) em corrente contínua por estação do ano

[kWh/mês]

\begin{tabular}{cccccccccccc}
\hline $\begin{array}{c}\text { Estação } \\
\text { do ano }\end{array}$ & $\begin{array}{c}\text { Si-Mono } \\
\text { (rígido) }\end{array}$ & $\begin{array}{c}\text { Si-Poli } \\
\text { (rígido) }\end{array}$ & $\begin{array}{c}\text { CaTe } \\
\text { (Filme } \\
\text { Fino) }\end{array}$ & $\begin{array}{c}\text { ucSi- } \\
\text { aSiH } \\
\text { (Filme } \\
\text { Fino) }\end{array}$ & $\begin{array}{c}\text { CIS AV } \\
\text { (Filme } \\
\text { Fino) }\end{array}$ & $\begin{array}{c}\text { CIS SF } \\
\text { (Filme } \\
\text { Fino) }\end{array}$ & $\begin{array}{c}\text { CIGS } \\
\text { (Filme } \\
\text { Fino) }\end{array}$ & $\begin{array}{c}\text { Vidro } \\
\text { FVST Si- } \\
\text { Poli 36\% }\end{array}$ & $\begin{array}{c}\text { Vidro } \\
\text { FVST Si- } \\
\text { Poli 16\% }\end{array}$ & $\begin{array}{c}\text { Vidro } \\
\text { FVST a-Si } \\
\mathbf{2 0 \%}\end{array}$ & $\begin{array}{c}\text { Vidro } \\
\text { FVT Si- } \\
\text { Mono 20\% }\end{array}$ \\
\hline Verão & 4.425 & 4.419 & 4.057 & 2.813 & 2.643 & 3.603 & 3.923 & 2.035 & 2.657 & 1.245 & 4.348 \\
\hline Outono & 8.048 & 8.046 & 7.505 & 5.045 & 5.023 & 6.698 & 7.447 & 3.740 & 4.880 & 2.251 & 7.914 \\
\hline Inverno & 8.728 & 8.720 & 8.127 & 5.453 & 5.455 & 7.255 & 8.069 & 4.045 & 5.280 & 2.433 & 8.574 \\
\hline Primavera & 4.404 & 4.398 & 4.033 & 2.795 & 2.628 & 3.574 & 3.888 & 2.020 & 2.637 & 1.236 & 4.323 \\
\hline Ano & $\mathbf{2 5 . 6 0 4}$ & $\mathbf{2 5 . 5 8 3}$ & $\mathbf{2 3 . 7 2 2}$ & $\mathbf{1 6 . 1 0 7}$ & $\mathbf{1 5 . 7 4 8}$ & $\mathbf{2 1 . 1 3 0}$ & $\mathbf{2 3 . 3 2 7}$ & $\mathbf{1 1 . 8 4 0}$ & $\mathbf{1 5 . 4 5 4}$ & $\mathbf{7 . 1 6 4}$ & $\mathbf{2 5 . 1 5 9}$ \\
\hline
\end{tabular}

Participação da energia gerada (Earray) por estação no total gerado no ano [\%]

\begin{tabular}{|c|c|c|c|c|c|c|c|c|c|c|c|}
\hline $\begin{array}{c}\text { Estação } \\
\text { do ano }\end{array}$ & $\begin{array}{c}\text { Si-Mono } \\
\text { (rígido) }\end{array}$ & $\begin{array}{l}\text { Si-Poli } \\
\text { (rígido) }\end{array}$ & $\begin{array}{c}\text { CaTe } \\
\text { (Filme } \\
\text { Fino) }\end{array}$ & $\begin{array}{c}\text { ucSi- } \\
\text { aSiH } \\
\text { (Filme } \\
\text { Fino) } \\
\end{array}$ & $\begin{array}{c}\text { CIS AV } \\
\text { (Filme } \\
\text { Fino) }\end{array}$ & $\begin{array}{c}\text { CIS SF } \\
\text { (Filme } \\
\text { Fino) }\end{array}$ & $\begin{array}{c}\text { CIGS } \\
\text { (Filme } \\
\text { Fino) }\end{array}$ & $\begin{array}{c}\text { Vidro } \\
\text { FVST Si- } \\
\text { Poli 36\% }\end{array}$ & $\begin{array}{c}\text { Vidro } \\
\text { FVST Si- } \\
\text { Poli 16\% }\end{array}$ & $\begin{array}{c}\text { Vidro } \\
\text { FVST a-Si } \\
20 \%\end{array}$ & $\begin{array}{c}\text { Vidro } \\
\text { FVST Si- } \\
\text { Mono 20\% }\end{array}$ \\
\hline Verão & $17,3 \%$ & $17,3 \%$ & $17,1 \%$ & $17,5 \%$ & $16,8 \%$ & $17,1 \%$ & $16,8 \%$ & $17,2 \%$ & $17,2 \%$ & $17,4 \%$ & $17,3 \%$ \\
\hline Outono & $31,4 \%$ & $31,5 \%$ & $31,6 \%$ & $31,3 \%$ & $31,9 \%$ & $31,7 \%$ & $31,9 \%$ & $31,6 \%$ & $31,6 \%$ & $31,4 \%$ & $31,5 \%$ \\
\hline Inverno & $34,1 \%$ & $34,1 \%$ & $34,3 \%$ & $33,9 \%$ & $34,6 \%$ & $34,3 \%$ & $34,6 \%$ & $34,2 \%$ & $34,2 \%$ & $34,0 \%$ & $34,1 \%$ \\
\hline Primavera & $17,2 \%$ & $17,2 \%$ & $17,0 \%$ & $17,4 \%$ & $16,7 \%$ & $16,9 \%$ & $16,7 \%$ & $17,1 \%$ & $17,1 \%$ & $17,3 \%$ & $17,2 \%$ \\
\hline Ano & $100,0 \%$ & $100,0 \%$ & $100,0 \%$ & $100,0 \%$ & $100,0 \%$ & $100,0 \%$ & $100,0 \%$ & $100,0 \%$ & $100,0 \%$ & $100,0 \%$ & $100,0 \%$ \\
\hline
\end{tabular}

Fonte: próprio autor com base nos resultados do APÊNDICE C (2017). 
APÊNDICE E - Densidade de energia gerada por estação e por tecnologia

Densidade de energia gerada (Earray) em corrente contínua por estação do ano [kWh/m² $\operatorname{modFV}]$

\begin{tabular}{|c|c|c|c|c|c|c|c|c|c|c|c|}
\hline $\begin{array}{c}\text { Estação } \\
\text { do ano }\end{array}$ & $\begin{array}{c}\text { Si-Mono } \\
\text { (rígido) }\end{array}$ & $\begin{array}{l}\text { Si-Poli } \\
\text { (rígido) }\end{array}$ & $\begin{array}{l}\text { CaTe } \\
\text { (Filme } \\
\text { Fino) }\end{array}$ & $\begin{array}{l}\text { ucSi- } \\
\text { aSiH } \\
\text { (Filme } \\
\text { Fino) }\end{array}$ & $\begin{array}{c}\text { CIS AV } \\
\text { (Filme } \\
\text { Fino) }\end{array}$ & $\begin{array}{c}\text { CIS SF } \\
\text { (Filme } \\
\text { Fino) }\end{array}$ & $\begin{array}{l}\text { CIGS } \\
\text { (Filme } \\
\text { Fino) }\end{array}$ & $\begin{array}{c}\text { Vidro } \\
\text { FVST Si- } \\
\text { Poli } \mathbf{3 6 \%}\end{array}$ & $\begin{array}{l}\text { Vidro } \\
\text { FVST Si- } \\
\text { Poli 16\% }\end{array}$ & $\begin{array}{c}\text { Vidro } \\
\text { FVST a-Si } \\
20 \%\end{array}$ & $\begin{array}{c}\text { Vidro } \\
\text { FVST Si- } \\
\text { Mono } 20 \%\end{array}$ \\
\hline Verão & 21,8 & 21,8 & 20,1 & 13,9 & 13,9 & 18,4 & 18,2 & 10,3 & 13,1 & 5,9 & 19,2 \\
\hline Outono & 39,6 & 39,6 & 37,2 & 24,9 & 26,4 & 34,2 & 34,6 & 19,0 & 24,0 & 10,7 & 34,9 \\
\hline Inverno & 43,0 & 43,0 & 40,2 & 26,9 & 28,7 & 37,0 & 37,5 & 20,5 & 26,0 & 11,5 & 37,8 \\
\hline Primavera & 21,7 & 21,7 & 20,0 & 13,8 & 13,8 & 18,2 & 18,1 & 10,3 & 13,0 & 5,9 & 19,0 \\
\hline Ano & 126,1 & 126,0 & 117,4 & 79,3 & 82,9 & 107,8 & 108,5 & 60,1 & 76,1 & 34,0 & 110,8 \\
\hline
\end{tabular}

Variação da densidade de energia gerada (Earray) entre estações subsequentes do ano [\%]

\begin{tabular}{|c|c|c|c|c|c|c|c|c|c|c|c|}
\hline $\begin{array}{l}\text { Estação } \\
\text { do ano }\end{array}$ & $\begin{array}{l}\text { Si-Mono } \\
\text { (rígido) }\end{array}$ & $\begin{array}{l}\text { Si-Poli } \\
\text { (rígido) }\end{array}$ & $\begin{array}{c}\text { CaTe } \\
\text { (Filme } \\
\text { Fino) }\end{array}$ & $\begin{array}{c}\text { ucSi- } \\
\text { aSiH } \\
\text { (Filme } \\
\text { Fino) }\end{array}$ & $\begin{array}{c}\text { CIS AV } \\
\text { (Filme } \\
\text { Fino) }\end{array}$ & $\begin{array}{c}\text { CIS SF } \\
\text { (Filme } \\
\text { Fino) }\end{array}$ & $\begin{array}{l}\text { CIGS } \\
\text { (Filme } \\
\text { Fino) }\end{array}$ & $\begin{array}{c}\text { Vidro } \\
\text { FVST Si- } \\
\text { Poli } \mathbf{3 6 \%}\end{array}$ & $\begin{array}{l}\text { Vidro } \\
\text { FVST Si- } \\
\text { Poli 16\% }\end{array}$ & $\begin{array}{c}\text { Vidro } \\
\text { FVST a-Si } \\
20 \%\end{array}$ & $\begin{array}{c}\text { Vidro } \\
\text { FVST Si- } \\
\text { Mono } 20 \%\end{array}$ \\
\hline ^ Verão & $0,5 \%$ & $0,5 \%$ & $0,6 \%$ & $0,6 \%$ & $0,6 \%$ & $0,8 \%$ & $0,9 \%$ & $0,8 \%$ & $0,7 \%$ & $0,7 \%$ & $0,6 \%$ \\
\hline Outono & $81,9 \%$ & $82,1 \%$ & $85,0 \%$ & $79,4 \%$ & $90,1 \%$ & $85,9 \%$ & $89,9 \%$ & $83,7 \%$ & $83,7 \%$ & $80,8 \%$ & $82,0 \%$ \\
\hline Inverno & $8,5 \%$ & $8,4 \%$ & $8,3 \%$ & $8,1 \%$ & $8,6 \%$ & $8,3 \%$ & $8,3 \%$ & $8,2 \%$ & $8,2 \%$ & $8,1 \%$ & $8,3 \%$ \\
\hline Primavera & $-49,5 \%$ & $-49,6 \%$ & $-50,4 \%$ & $-48,7 \%$ & $-51,8 \%$ & $-50,7 \%$ & $-51,8 \%$ & $-50,1 \%$ & $-50,0 \%$ & $-49,2 \%$ & $-49,6 \%$ \\
\hline $\begin{array}{l}\text { Verão p/ } \\
\text { Inverno }\end{array}$ & $97,3 \%$ & $\mathbf{9 7 , 3 \%}$ & $100,3 \%$ & $93,9 \%$ & $106,4 \%$ & $101,4 \%$ & $105,7 \%$ & $98,8 \%$ & $98,7 \%$ & $95,5 \%$ & $97,2 \%$ \\
\hline
\end{tabular}

Nota: Variação \% da estação posterior em relação a anterior.

Fonte: próprio autor com base nos resultados do APÊNDICE C (2017). 
APÊNDICE F - Participação e variação da energia gerada por estação e por grupo de tecnologia

Participação da energia gerada (Earray) por grupo de tecnologia [\%]

\begin{tabular}{ccccccc}
\hline $\begin{array}{c}\text { Estações } \\
\text { do ano }\end{array}$ & $\begin{array}{c}\text { Grupo } \\
\text { do silício } \\
\text { cristalino }\end{array}$ & $\begin{array}{c}\text { Grupo } \\
\text { do } \\
\text { silício } \\
\text { amorfo }\end{array}$ & $\begin{array}{c}\text { Grupo } \\
\text { Ca } \\
\text { CaTe }\end{array}$ & $\begin{array}{c}\text { Grupo } \\
\text { CIS/CIGS }\end{array}$ & $\begin{array}{c}\text { Grupo dos } \\
\text { vidros } \\
\text { FVST }\end{array}$ & $\begin{array}{c}\text { Grupo } \\
\text { do } \\
\text { Tandem }\end{array}$ \\
\hline Verão & $17,2 \%$ & $17,4 \%$ & $17,1 \%$ & $16,9 \%$ & $17,3 \%$ & $17,5 \%$ \\
\hline Outono & $31,5 \%$ & $31,4 \%$ & $31,6 \%$ & $31,8 \%$ & $31,5 \%$ & $31,3 \%$ \\
\hline Inverno & $34,1 \%$ & $33,9 \%$ & $34,3 \%$ & $34,5 \%$ & $34,1 \%$ & $33,9 \%$ \\
\hline Primavera & $17,1 \%$ & $17,3 \%$ & $17,0 \%$ & $16,8 \%$ & $17,1 \%$ & $17,4 \%$ \\
\hline Ano & $\mathbf{1 0 0 , 0 \%}$ & $\mathbf{1 0 0 , 0 \%}$ & $\mathbf{1 0 0 , 0 \%}$ & $\mathbf{1 0 0 , 0 \%}$ & $\mathbf{1 0 0 , 0 \%}$ & $\mathbf{1 0 0 , 0 \%}$ \\
\hline
\end{tabular}

Variação da densidade de energia gerada entre estações subsequentes [\%]

\begin{tabular}{ccccccc}
\hline $\begin{array}{c}\text { Estações } \\
\text { do ano }\end{array}$ & $\begin{array}{c}\text { Grupo } \\
\text { do silício } \\
\text { cristalino }\end{array}$ & $\begin{array}{c}\text { Grupo } \\
\text { do } \\
\text { silício } \\
\text { amorfo }\end{array}$ & $\begin{array}{c}\text { Grupo } \\
\text { do } \\
\text { CaTe }\end{array}$ & $\begin{array}{c}\text { Grupo } \\
\text { dos } \\
\text { CIS/CIGS }\end{array}$ & $\begin{array}{c}\text { Grupo dos } \\
\text { vidros } \\
\text { FVST }\end{array}$ & $\begin{array}{c}\text { Grupo } \\
\text { do } \\
\text { Tandem }\end{array}$ \\
\hline Verão & $0,6 \%$ & $0,7 \%$ & $0,6 \%$ & $0,7 \%$ & $0,7 \%$ & $0,6 \%$ \\
\hline Outono & $82,7 \%$ & $80,1 \%$ & $85,0 \%$ & $88,6 \%$ & $82,6 \%$ & $79,4 \%$ \\
\hline Inverno & $8,3 \%$ & $8,1 \%$ & $8,3 \%$ & $8,4 \%$ & $8,2 \%$ & $8,1 \%$ \\
\hline Primavera & $-49,8 \%$ & $-49,0 \%$ & $-50,4 \%$ & $-51,5 \%$ & $-49,7 \%$ & $-48,7 \%$ \\
\hline $\begin{array}{l}\text { Verão p/ } \\
\text { Inverno }\end{array}$ & $\mathbf{9 7 , 9 \%}$ & $\mathbf{9 4 , 7 \%}$ & $\mathbf{1 0 0 , 3 \%}$ & $\mathbf{1 0 4 , 5 \%}$ & $\mathbf{9 7 , 5 \%}$ & $\mathbf{9 3 , 9 \%}$ \\
\hline
\end{tabular}

Nota: Variação \% da estação posterior em relação da anterior. 
APÊNDICE G - Relação entre a densidade de energia gerada (Earray) e o índice de degradação dos módulos

Densidade de energia gerada $\left[\mathrm{kWh} / \mathrm{m}^{2} \operatorname{modFV}\right]$ por índice de degradação do módulo e por tecnologia

\begin{tabular}{|c|c|c|c|c|c|c|}
\hline \multirow{2}{*}{ Grupo } & \multirow{2}{*}{ Classificação } & \multicolumn{5}{|c|}{ Degradação do módulo (\% ao ano) } \\
\hline & & $0,40 \%$ & $\mathbf{0 , 5 8 \%}$ & $0,65 \%$ & $1,16 \%$ & $1,31 \%$ \\
\hline \multirow{2}{*}{$\begin{array}{l}\text { Silício cristalino } \\
\text { (rígidos) }\end{array}$} & Si Mono & 126,1 & & & & \\
\hline & Si Poli & & 126,0 & & & \\
\hline $\begin{array}{l}\text { Silicio amorfo/ } \\
\text { microcris talino }\end{array}$ & ucSi-aSiH & & & & 79,3 & \\
\hline \multirow{3}{*}{ CIS/CIGS } & CIS AV & & & & & 82,9 \\
\hline & CIS SF & & & & & 107,8 \\
\hline & CIGS & & & & & 108,5 \\
\hline CaTe & $\mathrm{CdTe}$ & & & 117,4 & & \\
\hline \multirow{4}{*}{$\begin{array}{c}\text { Vidros FV } \\
\text { semitransparentes }\end{array}$} & Vidro FVST Si Poli $36 \%$ & & 60,1 & & & \\
\hline & Vidro FVST Si Poli $16 \%$ & & 76,1 & & & \\
\hline & Vidro FVST Si Mono $20 \%$ & & 110,8 & & & \\
\hline & Vidro FVST a-Si $20 \%$ & & & & 34,0 & \\
\hline
\end{tabular}

Fonte: próprio autor (2017). 
APÊNDICE H - Relação entre a densidade de energia gerada (Earray) e sua variação entre as estações verão-inverno

Densidade de energia gerada $\left[\mathrm{kWh} / \mathrm{m}^{2} \operatorname{modFV}\right]$ e sua variação entre as estações verão-inverno [\%]

\begin{tabular}{|c|c|c|c|c|c|c|c|c|c|c|c|}
\hline \multirow{2}{*}{ Grupo } & \multirow{2}{*}{ Classificação } & \multicolumn{10}{|c|}{ Variação da densidade de energia gerada no inverno em relação a do verão [\%] } \\
\hline & & $\mathbf{9 3 , 9 \%}$ & $95,5 \%$ & $97,2 \%$ & $\mathbf{9 7 , 3 \%}$ & $98,7 \%$ & $98,8 \%$ & $100,3 \%$ & $101,4 \%$ & $105,7 \%$ & $106,4 \%$ \\
\hline \multirow{2}{*}{$\begin{array}{l}\text { Silício cristalino } \\
\text { (rígidos) }\end{array}$} & Si Mono & & & & 126,1 & & & & & & \\
\hline & Si Poli & & & & 126,0 & & & & & & \\
\hline $\begin{array}{l}\text { Silicio amorfo/ } \\
\text { microcristalino }\end{array}$ & ucSi-aSiH & 79,3 & & & & & & & & & \\
\hline \multirow{3}{*}{ CIS/CIGS } & CIS AV & & & & & & & & & & 82,9 \\
\hline & CIS SF & & & & & & & & 107,8 & & \\
\hline & CIGS & & & & & & & & & 108,5 & \\
\hline CaTe & $\mathrm{CdTe}$ & & & & & & & 117,4 & & & \\
\hline \multirow{4}{*}{$\begin{array}{c}\text { Vidros FV } \\
\text { semitransparentes }\end{array}$} & Vidro FVST Si Poli $36 \%$ & & & & & & 60,1 & & & & \\
\hline & Vidro FVST Si Poli 16\% & & & & & 76,1 & & & & & \\
\hline & Vidro FVST Si Mono 20\% & & & 110,8 & & & & & & & \\
\hline & Vidro FVST a-Si $20 \%$ & & 34,0 & & & & & & & & \\
\hline
\end{tabular}

Fonte: próprio autor (2017). 
ANEXO A - Tabela de eficiência de células solares (Solar cell efficiency tables - version 48)

${ }^{a}$ Spectral response and current-voltage curve reported in Version 44 of these Tables. bspectral response and current-voltage curve reported in Version 47 of these Tables. 'Reported on a 'per cell' basis.

Spectral responses and current-voltage curve reported in Version 45 of these Tables. Recalibrated from original measurement.

'Spectral response and current-voltage curve reported in Version 40 of these Tables. ${ }^{9}$ Spectral response and current-voltage curve reported in Version 46 of these Tables.

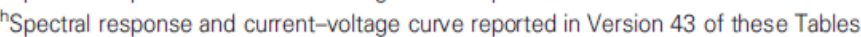

iSpectral response and current-voltage curve reported in the present version of these Tables. Stabilised by $1000 \mathrm{~h}$ exposure to 1 sun light at $50 \mathrm{C}$.

Not measured at an external laboratory.

Not stabilised, initial efficiency. Reference 19 reviews the stability of similar devices. minitial performance (not stabilised). Reference 62 reviews the stability of similar devices. ${ }^{n}$ Spectral response and current-voltage curve reported in Version 41 of these Tables.

Initial performance (not stabilised). References 63 and 64 review the stability of similar devices. PSpectral response and/or current-voltage curve reported in Version 42 of these Tables.

Fonte: GREEN et al (2016)
Table I. Confirmed terr estrial cell and submodule efficiencies measured under the global AM 1.5 spectrum (1000 W/m $/ \mathrm{m}^{2}$ at $25^{\circ} \mathrm{C}$ (IEC 60904-3: 2008, ASTM G-173-03 global).

\begin{tabular}{|c|c|c|c|c|c|c|c|}
\hline Classification & $\begin{array}{c}\text { Efficiency } \\
(\%)\end{array}$ & $\begin{array}{l}\text { Area } \\
\left(\mathrm{cm}^{2}\right) \\
\end{array}$ & $\begin{array}{l}V_{\infty} \\
\text { (V) }\end{array}$ & $\begin{array}{c}J_{s c} \\
\left.(m A v a)^{2}\right)\end{array}$ & $\begin{array}{c}\text { Fill factor } \\
(\%)\end{array}$ & $\begin{array}{l}\text { Test centre } \\
\text { (date) }\end{array}$ & Description \\
\hline \multicolumn{8}{|l|}{ Silicon } \\
\hline 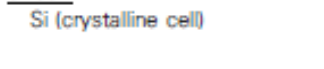 & $25.6 \pm 0.5$ & 143.7 (da) & 0.740 & $41.8^{a}$ & 82.7 & AIST $(2 / 14)$ & $\begin{array}{l}\text { Panasonic HIT, rear } \\
\text { junction [11] }\end{array}$ \\
\hline Si (multicrystalline cell) & $21.3 \pm 0.4$ & $242.74(t)$ & 0.6678 & $39.80^{\circ}$ & 80.0 & FhG-SE (11/15) & Trina Solar [21] \\
\hline Si (thin transfer submodule) & $21.2 \pm 0.4$ & 239.7 (ap) & $0.687^{\circ}$ & $38.50^{\circ}$ & 80.3 & NREL $(4 / 14)$ & Solevel $35 \mu \mathrm{m}$ thich] 122$]$ \\
\hline Si (ttin film minimodule] & $10.5 \pm 0.3$ & 94.0 (ap) & $0.492^{\mathrm{c}}$ & $29.7^{\circ}$ & 72.1 & FhG-ISE $(807)^{\circ}$ & $\begin{array}{l}\text { CSG Solar } \\
\mid<2 \mu \mathrm{m} \text { on gass) [23] }\end{array}$ \\
\hline \multicolumn{8}{|l|}{$\|-V$ cellss } \\
\hline GaAs (thin film cell) & $28.8 \pm 0.9$ & 0.9927 (ap) & ) 1.122 & $29.68^{\prime}$ & 86.5 & NREL [5/12] & Alta Devices [24] \\
\hline GaAs (multicrystalline) & $18.4 \pm 0.5$ & $4.011(t)$ & 0.994 & 23.2 & 79.7 & NRE $(11 / 95)^{\mu}$ & RTI, Ge substrate [25] \\
\hline InP (crystalline cell) & $22.1 \pm 0.7$ & $4.02(t)$ & 0.878 & 29.5 & 85.4 & NREL $(4,90)^{d}$ & Spire, epitaxial [26] \\
\hline \multicolumn{8}{|l|}{ Thin Film Chalcogenide } \\
\hline CIGS (celli) & $21.0 \pm 0.6$ & 0.9927 (ар) & 0.757 & $35.70^{\circ}$ & 77.6 & FhG-ISE (4/14) & Solibro, on glass [27] \\
\hline CIGS (minimodule) & $18.7 \pm 0.6$ & 15.892 ddal & $0.701^{\mathrm{c}}$ & 35.29 & 75.6 & FhG-ISE (9/13) & Solitro, 4 serial cels [28] \\
\hline CdTe icell) & $21.0 \pm 0.4$ & $1.0623(a p)$ & 0.8759 & $30.25^{d}$ & 79.4 & Newport [B/14] & First Solat, on glass [29] \\
\hline CZTSSe (cell) & $9.8 \pm 0.2$ & 1.115 (da) & 0.5073 & $31.95^{i}$ & 60.2 & Newport $(4 / 16)$ & IMRA Europe [4] \\
\hline CZTS (cell) & $7.6 \pm 0.1$ & 1.067 (da) & 0.6585 & $20.43^{i}$ & 56.7 & NREL $(4 / 16)$ & UNSW [5] \\
\hline \multicolumn{8}{|l|}{ Amorphous/microcrystaline } \\
\hline Si (amorphous cell) & $10.2 \pm 0.3$ & 1.001 (da) & 0.896 & $16.36^{d}$ & 69.8 & AIST (7/14) & AIST [30] \\
\hline Si (microcrystalline cell) & $11.8 \pm 0.3^{k}$ & 1.044 (da) & 0.548 & $29.39^{\circ}$ & 73.1 & AIST $(10 / 14)$ & AIST [31] \\
\hline \multicolumn{8}{|l|}{ Perovskite } \\
\hline Perovskite (cell) & $19.7 \pm 0.6^{\prime}$ & $0.9917 \mathrm{dd}$ & 1.104 & $24.67^{i}$ & 72.3 & Newport $(3 / 16)$ & KRICT/UNIST [6] \\
\hline \multicolumn{8}{|l|}{ Dye sensitised } \\
\hline Dye (cell) & $11.9 \pm 0.4^{\mathrm{m}}$ & $1.005 \mathrm{da}$ & 0.744 & $22.47^{\prime \prime}$ & 71.2 & AIST (9/12) & Sharp 132] \\
\hline Dye (minimodule) & $10.7 \pm 0.4^{\mathrm{m}}$ & 26.55 (da) & $0.754^{\mathrm{e}}$ & 20.198 & 69.9 & AIST $(2 / 15)$ & Sharp, 7 serial cels 132] \\
\hline Dye (submodule) & $8.8 \pm 0.3^{n}$ & 398.8 (da) & $0.697^{e}$ & $18.42^{-}$ & 68.7 & AIST (9/12) & Shap, 26 serial cels [33] \\
\hline \multicolumn{8}{|l|}{$\underline{\text { Organic }}$} \\
\hline Organic (cell) & $11.2 \pm 0.3^{n}$ & 0.992 (da) & 0.780 & $19.30^{\prime}$ & 74.2 & AIST (10/15) & Toshiba [7] \\
\hline Organic (minimodule) & $9.7 \pm 0.3^{\circ}$ & 26.14 (da) & 0.806 & $16.47^{\circ 9}$ & 73.2 & AIST $(2 / 15)$ & Toshba [8 series calis) [34] \\
\hline \multicolumn{8}{|l|}{ Multijunction } \\
\hline $\begin{array}{l}\text { Five junction cel (bonded) } \\
(2.17 / 1.68 / 1.40 / 1.060 .73 \mathrm{eV} \text { ) }\end{array}$ & $38.8 \pm 1.2$ & 1.021 (ap) & 4.767 & 9.564 & 85.2 & NREL $\nabla / 13)$ & Spectrolab [35] \\
\hline$[2.17 / 1.68 / 1.40 / 1.06 / 0.73 \mathrm{eV})$ & $37.9 \pm 1.2$ & 1.047 (ap) & 3.065 & $14.27^{\circ}$ & 86.7 & AIST (2/13) & Sharp [3] \\
\hline GelnP/GeinAs/Ge, & $34.5 \pm 2.0$ & 27.83 (ap) & $2.66 / 0.65$ & $513.1 / 9.3$ & $85.6 / 79.0$ & NREL $(4 / 16)$ & UNSW/Azur/Trina [8] \\
\hline GainP/GaAs (monolthic) & $31.6 \pm 1.5$ & 0.999 (ap) & 2.538 & $14.18^{i}$ & 87.7 & NREL $(1 / 16)$ & Alta Devices [9] \\
\hline GalnP/Si (mech. stadk) & $29.8 \pm 1.5^{k}$ & 1.006 dda & $1.46 / 0.68$ & 3 14.1/22.7\% & $87.9 / 76.2$ & NREL (10/15) & $\begin{array}{l}\text { NREL/CSEM, } \\
\text { 4-terminal [10] }\end{array}$ \\
\hline a-SVinc-Sihno-Si (thin film) & $13.6 \pm 0.4^{x}$ & $1.043 \mathrm{dal}$ & 1.901 & $9.92^{\mathrm{a}}$ & 72.1 & AIST (1/15) & AIST [37] \\
\hline a-Sinco-Si thin film cello & $12.7 \pm 0.4 \%$ & i.x 1.000 (da) & 1.342 & $13.45^{d}$ & 70.2 & AIST (10/14) & AIST $[30,31]$ \\
\hline
\end{tabular}




\section{ANEXO B - Tabela de eficiência de células solares (Solar cell efficiency tables - version 48)}

Table II. Confirmed terrestrial module efficiencies measured under the global AM1.5 spectrum $\left(1000 \mathrm{~W} / \mathrm{m}^{2}\right)$ at a cell temperature of $25^{\circ} \mathrm{C}$ (IEC 60904-3: 2008, ASTM G-173-03 global).

\begin{tabular}{|c|c|c|c|c|c|c|c|}
\hline Classification & Efficiency $(\%)$ & Area $\left(\mathrm{cm}^{2}\right)$ & $V_{o c}(\mathrm{~V})$ & $I_{\mathrm{sc}}(\mathrm{A})$ & $\mathrm{FF}(\%)$ & Test centre (date) & Description \\
\hline Si (crystalline) & $23.8 \pm 0.5$ & 11562 (ap) & 53.4 & $6.32^{\mathrm{a}}$ & 81.6 & AIST $(1 / 16)$ & Panasonic (72 cells) [11] \\
\hline Si (multicrystalline) & $19.5 \pm 0.4$ & 15349 (ap) & 41.53 & $9.299^{\mathrm{a}}$ & 77.4 & FhG-ISE (12/15) & Hanwha Q Cells (120 cells) [12] \\
\hline GaAs (thin film) & $24.1 \pm 1.0$ & 858.5 (ap) & 10.89 & $2.255^{\mathrm{b}}$ & 84.2 & NREL (11/12) & Alta Devices [38] \\
\hline CdTe (thin film) & $18.6 \pm 0.6$ & 7038.8 (ap) & 110.6 & $1.533^{\mathrm{a}}$ & 74.2 & NREL (4/15) & First Solar, monolithic [39] \\
\hline CIGS (Cd free) & $17.5 \pm 0.5$ & 808 (da) & 47.6 & $0.408^{\mathrm{C}}$ & 72.8 & AIST (6/14) & Solar Frontier (70 cells) [40] \\
\hline CIGS (large) & $15.7 \pm 0.5$ & 9703 (ap) & 28.24 & $7.254^{d}$ & 72.5 & NREL $(11 / 10)$ & Miasole [41] \\
\hline a-Si/nc-Si (tandem) & $12.3 \pm 0.3^{e}$ & $14322(\mathrm{t})$ & 280.1 & $0.902^{\dagger}$ & 69.9 & ESTI (9/14) & TEL Solar, Trubbach Labs [42] \\
\hline Organic & $8.7 \pm 0.3^{g}$ & 802 (da) & 17.47 & $0.569^{c}$ & 70.4 & AIST $(5 / 14)$ & Toshiba [34] \\
\hline \multicolumn{8}{|l|}{ Multijunction } \\
\hline $\operatorname{lnGaP} / \mathrm{GaAs} / \mathrm{lnGas}$ & $31.2 \pm 1.2$ & 968 (da) & 23.95 & 1.506 & 93.6 & AIST $(2 / 16)$ & Sharp (32 cells) [13] \\
\hline
\end{tabular}

CIGSS, CulnGaSSe; a-Si, amorphous silicon/hydrogen alloy; a-SiGe, amorphous silicon/germanium/hydrogen alloy; nc-Si, nanocrystalline or microcrystalline silicon; (t), total area; (ap), aperture area; (da), designated illumination area; FF, fill factor.

aSpectral response and/or current-voltage curve reported in the present version of these Tables.

bSpectral response and current-voltage curve reported in Version 41 of these Tables.

'Spectral response and/or current-voltage curve reported in Version 45 of these Tables.

${ }^{d}$ Spectral response reported in Version 37 of these Tables.

eStabilised at the manufacturer to the $2 \%$ level following IEC procedure of repeated measurements.

${ }^{\text {f }}$ Spectral response and/or current-voltage curve reported in Version 46 of these Tables.

Initial performance (not stabilised).

Fonte: GREEN et al (2016) 


\section{ANEXO C - Gráfico da evolução de eficiência de células NREL}

\section{(Best Reasearch Cell Efficiencies - 06/08/2015)}

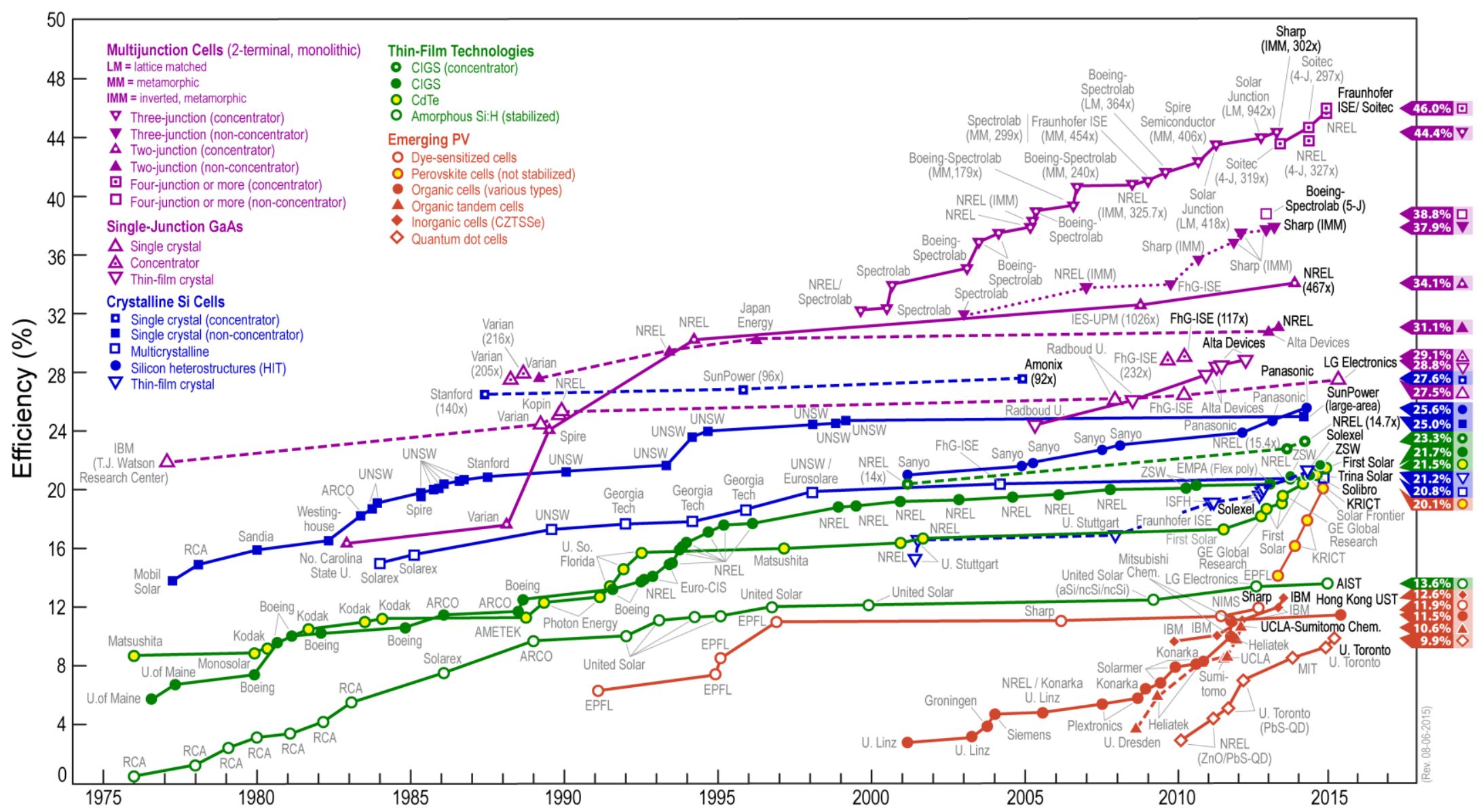

Fonte: NREL (2015)

Multi-junction cells: Concentrator PV, Solar panels on spacecraft, GaAs $\square$ Crystalline Si Cells: Single crystal, Multicrystalline

Thin-Film Technologies: CdTe, CIGS, Amorphous Si $\square$ Emerging PV: Dye-sensitized solar cells, Perovskite solar cells, Organic solar cells, CZTSSe, Quantum dot solar cells 